UNIVERSIDADE ESTADUAL PAULISTA

FACULDADE DE MEDICINA VETERINÁRIA E ZOOTECNIA

\title{
POLIOENCEFALOMALACIA EXPERIMENTALMENTE INDUZIDA PELA INGESTÃO DE DIETA COM ALTO TEOR DE ENXOFRE OU PELO HERPESVÍRUS BOVINO 5 EM BOVINOS
}

PAULO HENRIQUE JORGE DA CUNHA

Tese apresentada junto ao Programa de Pósgraduação em Medicina Veterinária para obtenção do título de Doutor.

Orientador: Prof. Dr. Alexandre Secorun Borges Co-Orientador: Prof. Dr. Rogério Martins Amorim

Botucatu - SP

2010 
FICHA CATALOGRÁFICA ELABORADA PELA SEÇÃO TÉCNICA DE AQUISIÇÃO E TRATAMENTO

DA INFORMAÇÃO

DIVISÃO TÉCNICA DE BIBLIOTECA E DOCUMENTAÇÃO - CAMPUS DE BOTUCATU - UNESP

BIBLIOTECÁRIA RESPONSÁVEL: Selma Maria de Jesus

Cunha, Paulo Henrique Jorge da.

Polioencefalomalacia experimentalmente induzida pela ingestão de dieta com alto teor de enxofre ou pelo herpesvírus bovino $5 \mathrm{em}$ bovinos/ Paulo Henrique Jorge da Cunha. - Botucatu [128], 2010.

Tese (doutorado) - Universidade Estadual Paulista, Faculdade de Medicina Veterinária e Zootecnia, Botucatu, 2009.

Orientador: Alexandre Secorun Borges

Assunto CAPES: 50501062

1. Bovino - Doenças 2. Neurologia veterinária 3.Modelos experimentais

CDD 636.208968

Palavras-chave: Bovino; Enxofre; BoHV-5; Polioencefalomalacia 
Nome do autor: Paulo Henrique Jorge da Cunha

Título: POLIOENCEFALOMALACIA EXPERIMENTALMENTE INDUZIDA PELA INGESTÃO DE DIETA COM ALTO TEOR DE ENXOFRE OU PELO HERPESVÍRUS BOVINO 5 EM BOVINOS

\section{COMISSÃO EXAMINADORA}

Prof. Dr. Alexandre Secorun Borges

Presidente e Orientador

Departamento de Clinica Veterinária

FMVZ - UNESP - Botucatu

Prof. Dr. Luiz Claudio Nogueira Mendes

Membro

Departamento de Clínica, Cirurgia e Reprodução Animal

Faculdade de Odontologia de Araçatuba

Prof. Dr. Paulo Cesar Maiorka

Membro

Departamento de Patologia Veterinária

Faculdade de Medicina Veterinária e Zootecnia - USP

Prof. Dr. Amauri Alcindo Alfieri

Membro

Departamento de Medicina Veterinária Preventiva

Centro de Ciências Agrárias - Universidade Estadual de Londrina

Prof. Dr. José Renato Junqueira Borges

Membro

Faculdade de Agronomia e Medicina Veterinária

Universidade de Brasília

Data da defesa: 19 de janeiro de 2010. 
Aos meus pais, SALVADOR E NOÊMIA, pelo amor, fé e força.

Aos meus irmãos, MARCO ANTONIO e ANTONIO HENRIQUE, pelo companheirismo e incentivo nas horas mais difíceis da minha vida.

Dedico. 


\section{AGRADECIMENTOS}

À DEUS: “Eu vos louvarei de todo o coração, Senhor. Quando vos invoquei, vós me respondestes; fizestes crescer a força da minha alma”.

Ao Prof. Alexandre Secorun Borges, o meu agradecimento especial pela orientação, pelo incentivo, pela confiança, pela amizade e pelos ensinamentos. Agradecimentos também a sua esposa Alessandra Gonçalves Borges.

A minha namorada Amanda, pela ajuda, paciência e por estar ao meu lado sempre me apoiando.

Aos pós-graduandos e amigos, Peres Ramos Badial, José Paes de Oliveira Filho, Andreza Pimenta de Oliveira e Didier Quevedo Cagnini, pela amizade, pelo convívio extremamente agradável, sem os quais este trabalho não estaria concluído.

As acadêmicas da graduação e bolsistas PIBIC, Ana Claudia Gorino e Mariana Fontanetti Marinheiro pelo auxílio e dedicação ao projeto.

A bióloga e bolsista da FAPESP, Jésica Ruiz Silva pelo auxílio no desenvolvimento das atividades do projeto no Laboratório de Biologia Molecular da Clínica Veterinária da FMVZ/UNESP.

Ao Prof. Rogério Martins Amorim pela co-orientação e auxílio na realização deste trabalho.

A Prof ${ }^{\mathfrak{a}}$. Renée Laufer Amorim pelo auxílio na interpretação dos dados histopatológicos.

Ao Prof. Amauri Alcindo Alfieri e sua equipe do Laboratório de Virologia Animal do Centro de Ciências Agrárias da Universidade Estadual de Londrina por ceder à estirpe viral do herpesvírus bovino tipo 5 e auxílio nos exames virológicos. 
Ao Prof. Júlio Augusto Naylor Lisboa por estar sempre disponível para esclarecer as dúvidas e pelas sugestões que ajudaram a compor este trabalho.

A Prof ${ }^{a}$. Regina Kiomi Takahira e as residentes do Laboratório de Patologia Clínica, especialmente Danielle Passarelli e Lívia Fagundes Moares, responsáveis pela realização dos hemogramas e pelas análises do líquido cefalorraquidiano.

Ao prof. João Pessoa Araújo Junior e aos pós-graduandos do Laboratório de Diagnóstico Molecular, especialmente Taís Fukuta da Cruz e Andreza Soriano Figueiredo, por estarem sempre dispostos a colaborar no que foram solicitados.

A Dona Elza Secorun Borges por permitir a realização do experimento da dosagem de gás sulfídrico ruminal nos bovinos Nelore em sua propriedade e por me acolher por diversas vezes em sua residência em Londrina.

Aos docentes do Serviço de Clínica de Grandes Animais da FMVZ, Prof. Roberto Calderon Gonçalves e Prof. Simone Biagio Chiacchio, pela acolhida e cooperação na realização deste trabalho.

Aos amigos pós-graduandos Thiago Braga Izidoro, Fábio André Araújo e Flávia Augusta de Oliveira.

A secretária do Departamento de Clínica Médica, Marlene Dias de Camargo, por estar sempre disposta a colaborar no que foi solicitada.

Aos funcionários e Médicos Veterinários Residentes da Clínica de Grandes Animais da FMVZ/UNESP/ Botucatu pela amizade e ajuda na realização deste trabalho.

Ao Dr. Emílio Benedito Fanton, pelo auxilio no preparo da ração utilizada no protocolo de indução experimental de polioencefalomalacia por enxofre.

A FMVZ/UNESP por ter me acolhido durante o doutorado e pela receptividade. 
Ao Programa de Pós-Graduação em Medicina Veterinária, especialmente a Profa. Sheila Canevese Rahal (Coordenadora) e aos funcionários José Roberto de Lalla Júnior (Supervisor) e Maria Ap. Dias de Almeida Manoel, pelo auxílio e orientações com relação às questões burocráticas da pós-graduação.

À Universidade Federal de Goiás, a Escola de Veterinária, e em especial aos colegas de disciplina, pela oportunidade de realizar o curso de pós-graduação.

A CAPES, pela concessão da Bolsa de Pós-graduação (PICDT).

A FAPESP, pelo auxílio financeiro concedido para a realização deste trabalho. Aos animais, instrumentos de aprendizado e razão principal para o desenvolvimento da pesquisa. 


\section{LISTA DE QUADROS}

CAPÍTULO II

Quadro 1 Momentos em que foram realizados os exames físicos, as colheitas de amostras de sangue total e de fluido ruminal e as dosagens de sulfeto de hidrogênio ruminal $\left(\mathrm{H}_{2} \mathrm{~S}\right)$ dos bovinos mestiços do grupo que ingeriu ração sem sulfato de sódio (G1) e do que consumiu ração com sulfato de sódio (G2) nas três fases do protocolo de indução experimental de polioencefalomalacia em bezerros mestiços.

Quadro 2 Valores médios e desvios-padrão $(\bar{x} \pm \sigma)$ da temperatura retal $\left({ }^{\circ} \mathrm{C}\right)$, frequência cardíaca (batimentos/min) e respiratória (movimentos/min) e motricidade ruminal (movimentos/cinco min) aferidas nas três fases do protocolo de indução de polioencefalomalacia nos bezerros mestiços do grupo que ingeriu ração sem sulfato de sódio (G1) e do que consumiu ração com sulfato de sódio (G2).

Quadro 3 Valores médios e desvios-padrão $(\bar{x} \pm \sigma)$ dos eritrogramas 61 avaliados nas três fases do protocolo de indução de polioencefalomalacia nos bezerros mestiços do grupo que ingeriu ração sem sulfato de sódio (G1) e do que consumiu ração com sulfato de sódio $(\mathrm{G} 2)$.

Quadro 4 Valores médios e desvios-padrão $(\bar{x} \pm \sigma)$ dos leucogramas avaliados nas três fases do protocolo de indução de polioencefalomalacia nos bezerros mestiços do grupo que ingeriu ração sem sulfato de sódio (G1) e do que consumiu ração com sulfato de sódio $(\mathrm{G} 2)$.

Quadro 5 Valores médios e desvios-padrão $(\bar{x} \pm \sigma)$ do fibrinogênio plasmático $(\mathrm{g} / \mathrm{dL})$ e proteína plasmática $(\mathrm{mg} / \mathrm{dL})$ avaliados nas três fases do protocolo de indução de polioencefalomalacia nos bezerros mestiços do grupo que ingeriu ração sem sulfato de sódio (G1) e do que consumiu ração com sulfato de sódio (G2). 
Quadro 6 Valores médios e desvios-padrão $(\bar{x} \pm \quad \sigma)$ do sulfeto de 64 hidrogênio ruminal (ppm) avaliados nas três fases do protocolo de indução de polioencefalomalacia nos bezerros mestiços dos do grupo que ingeriu ração sem sulfato de sódio $(\mathrm{G} 1)$ e do que consumiu ração com sulfato de sódio (G2).

Quadro 7 Valores médios e desvios-padrão $(\bar{x} \pm \sigma)$ do $\mathrm{pH}$ ruminal avaliados nas três fases do protocolo de indução de polioencefalomalacia nos bezerros do grupo que ingeriu ração sem sulfato de sódio $(\mathrm{G} 1)$ e do que consumiu ração com sulfato de sódio $(\mathrm{G} 2)$.

Quadro 8 Valores individuais da contagem das hemácias, do total e 66 diferencial das células nucleadas, dos teores de glicose $(\mathrm{mg} / \mathrm{dL})$ liquórica e sérica e proteína $(\mathrm{mg} / \mathrm{dL})$ das amostras do líquido cefalorraquidiano colhidas no final da 3 fase do protocolo de indução de polioencefalomalacia nos bezerros mestiços do grupo que consumiu ração com sulfato de sódio (G2).

Quadro 9 Valores individuais da dosagem de chumbo realizada nos fragmentos de tecido hepático $(\mu \mathrm{g} / \mathrm{g})$ e renal $(\mu \mathrm{g} / \mathrm{g})$ colhidas do bezerro 10 do grupo que ingeriu ração sem sulfato de sódio (G1) e dos bezerros 1, 4 e 7 do que consumiu ração com sulfato de sódio $(\mathrm{G} 2)$. 
Quadro 1 Valores médios e desvios-padrão $(\bar{x} \pm \sigma)$ da temperatura retal 103 $\left({ }^{\circ} \mathrm{C}\right)$, frequência cardíaca (batimento/min) e respiratória (movimentos/min) e motricidade ruminal (movimento/cinco min) aferidos durante período de 30 dias nos seis bezerros mestiços após infecção experimental com herpesvirus bovino 5 (BoHV-5).

Quadro 2 Valores médios e desvios-padrão $(\bar{x} \pm \sigma)$ do eritrograma 104 avaliados antes da inoculação (M0) e no $5^{\circ}$ dia p.i. (M1), $9^{\circ}$ dia p.i. (M2), $14^{\circ}$ dia p.i. (M3), $19^{\circ}$ dia p.i (M4), $21^{\circ}$ dia p.i (M5), $26^{\circ}$ dia p.i (M6) e $30^{\circ}$ dia p.i (M7) dos bezerros mestiços após infecção experimental com o herpesvírus bovino 5 (BoHV-5).

Quadro 3 Valores médios e desvios-padrão $(\bar{x} \pm \sigma)$ do leucograma 105 avaliados antes da inoculação (M0) e no $5^{\circ}$ dia p.i. (M1), $9^{\circ}$ dia p.i. (M2), $14^{\circ}$ dia p.i. (M3), $19^{\circ}$ dia p.i (M4), $21^{\circ}$ dia p.i (M5), $26^{\circ}$ dia p.i (M6) e $30^{\circ}$ dia p.i (M7) dos bezerros mestiços após infecção experimental com o herpesvírus bovino 5 (BoHV-5).

Quadro 4 Valores médios e desvios-padrão $(\bar{x} \pm \sigma)$ do fibrinogênio 106 plasmático e proteína plasmática avaliados antes da inoculação (M0) e no $5^{\circ}$ dia p.i. (M1), $9^{\circ}$ dia p.i. (M2), $14^{\circ}$ dia p.i. (M3), $19^{\circ}$ dia p.i (M4), $21^{\circ}$ dia p.i (M5), $26^{\circ}$ dia p.i (M6) e $30^{\circ}$ dia p.i (M7) dos bezerros mestiços após infecção experimental com o herpesvírus bovino 5 (BoHV-5).

Quadro 5 Valores médios e desvios-padrão $(\bar{x} \pm \sigma)$ da contagem total e diferencial das células nucleadas, dos teores de glicose $(\mathrm{mg} / \mathrm{dL})$ e proteína $(\mathrm{mg} / \mathrm{dL})$ do líquido cefalorraquidiano coletados 10 dias p.i. (M1), 17 dias p.i. (M2), 24 dias p.i. (M3) e 30 dias p.i. (M4) dos bezerros mestiços após infecção experimental com o herpesvírus bovino 5 (BoHV-5). 
Quadro 6 Resultados da presença de DNA viral detectado pela PCR em 108 diferentes porções do sistema nervoso central (SNC) e do gânglio do trigêmeo dos seis bezerros mestiços após infecção experimental com herpesvírus bovino 5 (BoHV-5).

Quadro 7 Número de bezerros com lesão em cada área associado com a 109 distribuição e valores médios com os desvios-padrão da intensidade das lesões histológicas das diferentes porções do SNC e no gânglio do trigêmeo após infecção experimental com herpesvírus bovino 5 (BoHV-5).

Quadro 8 Valores do sulfeto de hidrogênio ruminal (ppm) dos seis bezerros mestiços avaliados antes da inoculação (M0) e no $7^{\circ}$ dia p.i. (M1), $14^{\circ}$ dia p.i. (M2), $21^{\circ}$ dia p.i. (M3), $28^{\circ}$ dia p.i (M4) após infecção experimental com o herpesvírus bovino 5 (BoHV-5).

Quadro 9 Valores do $\mathrm{pH}$ ruminal dos seis bezerros mestiços avaliados antes da inoculação (M0) e no $7^{\circ}$ dia p.i. (M1), $14^{\circ}$ dia p.i. (M2), $21^{\circ}$ dia p.i. (M3), $28^{\circ}$ dia p.i (M4) após infecção experimental com o herpesvírus bovino 5 (BoHV-5).

Quadro 10 Valores individuais da dosagem de chumbo realizada nos fragmentos de tecido hepático $(\mu \mathrm{g} / \mathrm{g})$ e renal $(\mu \mathrm{g} / \mathrm{g})$ colhidas dos seis bezerros mestiços após infecção experimental com herpesvírus bovino 5 (BoHV-5). 


\section{LISTA DE FIGURAS \\ CAPÍTULO II}

Figura 1 Box plot dos valores do sulfeto de hidrogênio ruminal (ppm)

68 aferidos nas três fases do protocolo de indução de polioencefalomalacia nos bezerros mestiços do grupo que ingeriu ração sem sulfato de sódio $(\mathrm{G} 1)$ e do que consumiu ração com sulfato de sódio (G2).

Figura 2 Bezerro 1. Edema dos córtex parietal e occipital (achatamento dos giros cerebrais) comprimindo a porção lateral esquerda do cerebelo.

Figura 3 Bezerro 1. Córtex parietal esquerdo. Presença de neurônios 69 vermelhos (setas). HE, obj. 20x.

Figura 4 Bezerro 1. Núcleos da base. Edema (vacúolos) e necrose 69 neuronal (setas). HE, obj. 40x.

Figura 5 Bezerro 1. Tálamo. Presença de neurônios vermelhos (setas). 69 HE, obj. 40x.

Figura 6 Bezerro 7. Ponte. Áreas de hemorragia perivascular. HE, obj. $20 x$.

Figura 7 Bezerro 7. Bulbo. Área de hemorragia ao redor do vaso sanguíneo. HE, obj. 20x. 


\section{LISTA DE FIGURAS \\ CAPÍTULO III}

Figura 1 Valores médios da variação da temperatura retal $\left({ }^{\circ} \mathrm{C}\right)$ aferidas diariamente à tarde durante período de 30 dias nos seis bezerros mestiços após infecção experimental com herpesvírus bovino tipo 5 (BoHV-5).

Figura 2 Bezerro controle. Córtex frontal. Os neurônios do córtex telencefálico possuem núcleos grandes, vesiculosos, nucléolo evidente e citoplasma levemente basofílico. HE, obj. 20x.

Figura 3 Bezerro 1. Córtex frontal. Os neurônios do córtex telencefálico apresentam núcleos picnóticos e citoplasma acidofílico encolhido (setas) e o edema de neurópilo. HE, obj. $20 x$.

Figura 4 Bezerro controle. Tálamo. Os neurônios do tálamo apresentam núcleos grandes e vesiculosos, nucléolo evidente e citoplasma levemente basofílico. HE, obj. 40x.

Figura 5 Bezerro 1. Tálamo. Infiltrado inflamatório mononuclear difuso, acentuado, associado a edema e degeneração axonal (seta). HE, obj. 40x.

Figura 6 Bezerro 3. Córtex frontal. Presença de manguitos perivasculares compostos por células mononucleares. HE, obj. $2,5 x$.

Figura 7 Bezerro 4. Núcleos da base. Presença de manguitos perivasculares compostos por células mononucleares. HE, obj. $2,5 \mathrm{x}$.

Figura 8 Bezerro 2. Tálamo. Áreas de hemorragia perivascular. HE, obj. 20x.

Figura 9 Bezerro 2. Tálamo. Área focal de malacia com presença de inúmeras células Gitter (setas) e hemorragia. HE, obj. 20x. 
Figura 10 Distribuição e intensidade da soma de todas as alterações histopatológicas (gliose focal, gliose difusa, edema de neurópilo, neurônios vermelhos, congestão, hemorragia, neuronofagia, manguitos perivasculares, meningite) no encéfalo dos seis bezerros mestiços após infecção experimental com herpesvírus bovino tipo 5 (BoHV-5). BO, bulbo na altura do óbex; $\mathrm{CF}$, córtex frontal; $\mathrm{CP}$, córtex parietal; $\mathrm{CO}$, córtex occipital; NB, núcleos basais; TA, tálamo; $\mathrm{ME}$, mesencéfalo; $\mathrm{PO}$, ponte; $\mathrm{BU}$, Bulbo; GG, Gânglio Gasser; CE, cerebelo. 


\section{LISTA DE ABREVIAÇÕES}

SNC - Sistema Nervoso Central

PEM - Polioencefalomalacia

BoHV-5 - Herpesvirus Bovino 5

LCR - Líquido Cefalorraquidiano

$\mathrm{H}_{2} \mathrm{~S}$ - Sulfeto de Hidrogênio ou Gás Sulfídrico

PCR - Reação em Cadeia da Polimerase

* Em virtude do uso consagrado na literatura técnica, algumas abreviações seguem sua grafia no inglês. 


\section{SUMÁRIO}

\section{CAPÍTULO I}

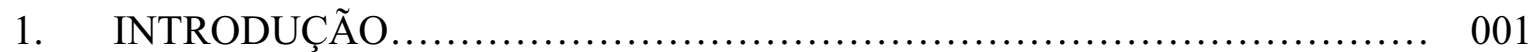

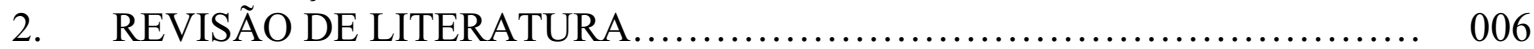

2.1. Polioencefalomalácia ocasionada por ingestão excessiva de enxofre.... 006

2.1.1. Fontes de enxofre..................................... 006

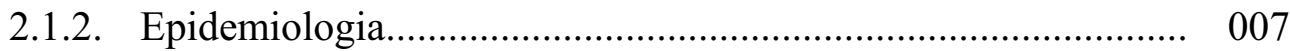

2.1.2.1. Surtos...................................... 007

2.1.2.2. Indução experimental............................ 011

2.1.3. Fisiopatogenia.......................................... 014

2.1.4. Sintomatologia Clínica..................................... 017

2.1.5. Diagnóstico Diferencial..................................... 018

2.1.5.1. Hemograma e bioquímica sérica.................. 019

2.1.5.2. Determinação da tiamina sérica.................. 020

2.1.5.3. Análise do LCR................................. 020

2.1.5.4. Achados de necropsia e histopatológico.................. 021

2.1.5.5. Diagnóstico virológico de BoHV-5............... 023

2.1.6. Diagnóstico Definitivo................................... 023

2.1.7. Tratamento............................................. 026

2.1.8. Medidas de Prevenção e Controle............................................ 028

CAPÍTULO II Trabalho científico....................................... 029

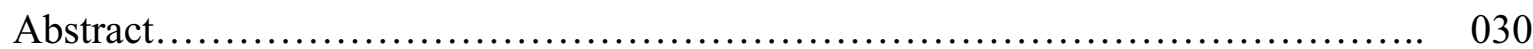

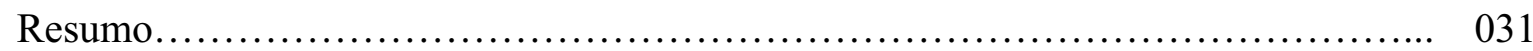

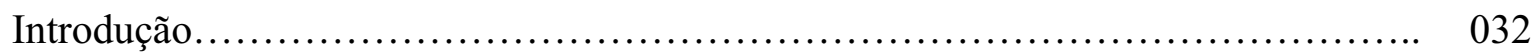

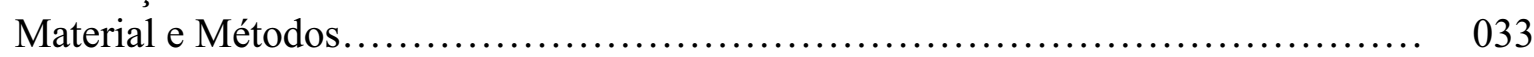

Resultados e Discussão...................................................... $\quad 040$

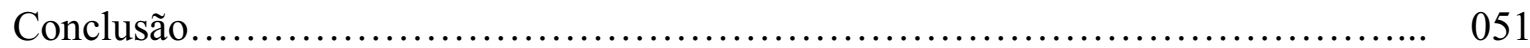

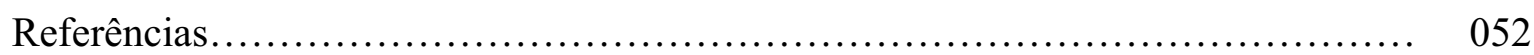

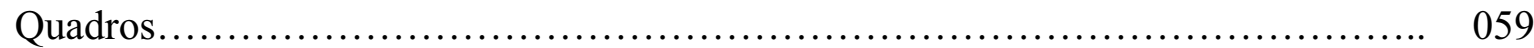

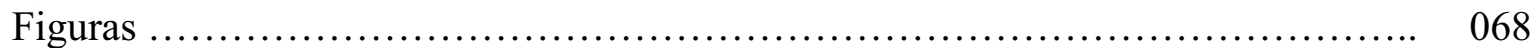

CAPÍTULO III Trabalho científico...................................... 070

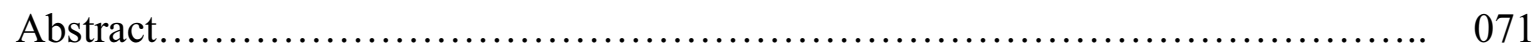

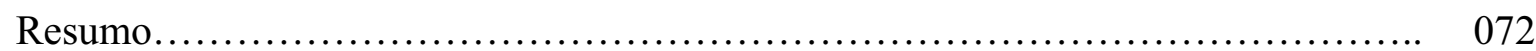

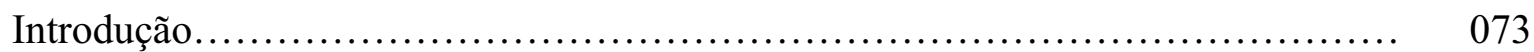

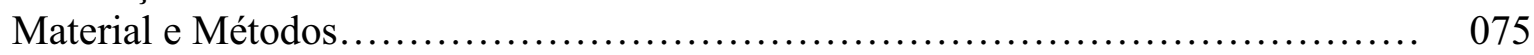

Resultados e Discussão.................................................... 081

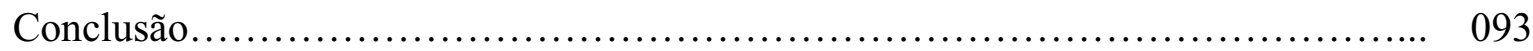

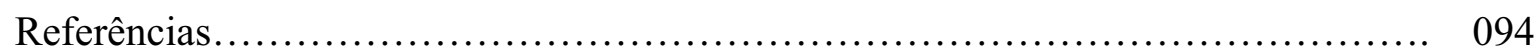

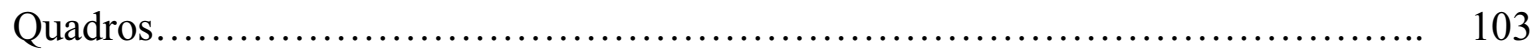

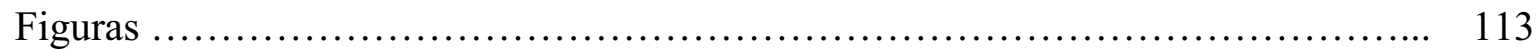

CONCLUSÕES GERAIS ..................................................... 119

REFERÊNCIAS (CAPÍTULO I) ............................................. 120

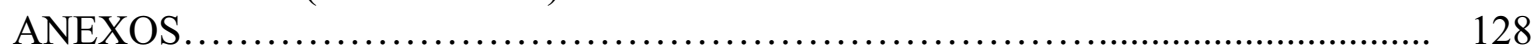
A. TABELAS INDIVIDUAIS
B. ARTIGOS ENVIADOS PARA REVISTA CIENCIA RURAL 
CUNHA, P.H.J. Polioencefalomalacia experimentalmente induzida pela ingestão de dieta com alto teor de enxofre ou pelo herpesvírus bovino $5 \mathrm{em}$ bovinos. Botucatu, 2010. 128p. Tese (Doutorado) - Faculdade de Medicina Veterinária e Zootecnia, Campus de Botucatu, Universidade Estadual Paulista.

\section{RESUMO}

O objetivo da tese foi de verificar os achados clínicos e laboratoriais da polioencefalomalacia (PEM) em bovinos ocasionada pela ingestão de dieta com alto teor de enxofre ou pelo herpesvírus bovino 5 (BoHV-5). No primeiro estudo realizouse indução de PEM pelo consumo excessivo de enxofre. Foram utilizados 10 bezerros, sendo que quatro bovinos ingeriram ração sem sulfato de sódio (G1), enquanto seis consumiram ração com sulfato de sódio (G2). Exames físicos e laboratoriais (hemograma, fibrinogênio plasmático e proteína plasmática, $\mathrm{pH}$ fluido ruminal, concentração do sulfeto de hidrogênio ruminal, líquido cerebrospinal e histopatológico) foram realizados. Um bezerro do grupo G2 apresentou sinais neurológicos e em todos do mesmo grupo detectou-se elevados valores de sulfeto de hidrogênio ruminal. Histologicamente as principais alterações observadas foram necrose neuronal cortical e lesões hemorrágicas nos núcleos basais, tálamo, mesencéfalo, ponte e bulbo. A ingestão de dieta com alto teor de enxofre $(0,52 \%)$ induziu PEM nos bezerros. No segundo estudo foi realizada inoculação experimental em seis bezerros com o BoHV-5 pela via intranasal com instilação de $0,5 \mathrm{~mL}$ do inóculo em cada narina, totalizando a dose viral de $10^{7,2} \mathrm{DICT}_{50} / \mathrm{mL}$. Durante 30 dias pós-infecção foram realizados exames físicos e os mesmos testes laboratoriais descritos no primeiro artigo. Foi investigada a presença do vírus em seis porções do encéfalo, no gânglio do trigêmeo e no líquido cefalorraquidiano (LCR) pela reação em cadeia da polimerase (PCR). Um bezerro apresentou sinais de encefalopatia. Pleocitose foi identificada no bezerro sintomático e nos assintomáticos. No exame histopalógico notou-se necrose cerebrocortical, encefalite e meningite não supurativa. A infecção experimental com o BoHV-5 ocasionou PEM nos bezerros, podendo ser assintomática.

Palavras-chave: necrose cerebrocortical; enxofre; bovino; BoHV-5. 
CUNHA, P.H.J. Experimentally polioencephalomalacia induced by excess sulphur intake or by bovine herpesvirus 5 in cattle. Botucatu, 2010. 128p. Tese (Doutorado) - Faculdade de Medicina Veterinária e Zootecnia, Campus de Botucatu, Universidade Estadual Paulista.

\section{ABSTRACT}

The aim of this thesis was to verify clinical and laboratorial aspects of polioencephalomalacia (PEM) in cattle caused by excess sulphur intake or by bovine herpesvirus 5 (BoHV-5). The first paper describes an experimental model to induced PEM with high sulphur intake. Ten calves were fed an experimental diet, four without sodium sulfate (G1) and six with (G2). The calves were clinically evaluated and laboratorial tests were performed (hematology, plasma fibrinogen, plasma protein, ruminal fluid $\mathrm{pH}$, ruminal hydrogen sulfide concentration, cerebrospinal fluid, gross and histopathological). High ruminal hydrogen sulfide concentration was detected in calves consuming sodium sulfate diet (G2). One out of six calves fed with highsulfate diet developed neurological signs. Cortical neuronal necrosis and hemorrhagic lesions in basal nuclei, thalamus, midbrain, pons and medulla oblongata were detected in calves from group G2. PEM in calves can result from excess sulphur intake $(0.52 \%$ dry matter). In the second paper, six calves were experimentally infected with BoHV5 with $0.5 \mathrm{~mL}$ of virus suspension $\left(10^{7,2} \mathrm{TCID}_{50}\right)$ in each nasal cavity. During the 30 days of experimental postinfection (p.i.) calves were clinically evaluated. Laboratorial tests were performed as described for the first study. Virus detection was investigated in six brain regions, trigeminal ganglia and cerebrospinal fluid (CSF) by polimerase chain reaction (PCR) assay. One out of the six calves developed signs of neurological disease. It was possible to detect CSF pleocytosis in all symptomatic and asymptomatic calves. The histology revealed cerebrocortical necrosis and non suppurative encephalitis and meningitis. PEM was induced in calves by experimental infection with BoHV-5 and can remain asymptomatic.

Key-words: cerebrocortical necrosis; cattle; sulphur; BoHV-5. 


\section{INTRODUÇÃO}

A pecuária desempenha um papel importante no cenário econômico nacional, porém a necessidade de aumentar a produção de alimentos para atender à demanda crescente de consumo exigirá dos sistemas de produção aumento na produtividade. Associadas ao incremento da produtividade, as questões sanitárias como a rastreabilidade e a segurança do alimento passam a interessar a todos. Assim, os potenciais riscos à saúde humana mostram claramente a necessidade de profissionalização de todos os componentes da cadeia produtiva, principalmente na questão da sanidade.

No Brasil, a raiva é a enfermidade neurológica mais frequentemente diagnosticada nos bovinos revelando a importância sócio-econômica e de saúde pública das enfermidades que acometem o sistema nervoso central (SNC). Ao se realizar o diagnóstico diferencial das encefalopatias dos bovinos, além da raiva deve-se também incluir a polioencefalomalacia (PEM) (Barros et al. 2006).

A PEM ou necrose cerebrocortical ou necrose cortical laminar é uma síndrome cerebrocortical degenerativa dos ruminantes e o termo é utilizado para descrever uma alteração morfológica caracterizada por amolecimento (malacia) da substância cinzenta (polio) do encéfalo (Gould 1998, 2000, Cebra \& Cebra 2004, Burgess 2008, Sant'Ana et al. 2009ab).

A primeira descrição da PEM na América do Norte foi realizada por Jensen et al. (1956), que descreveram uma desordem neurológica em bovinos e ovinos caracterizada clinicamente por cegueira, ataxia, decúbito e convulsões e nos achados histopatológicos identificaram necrose do córtex cerebral. Estudos subsequentes confirmaram a descrição inicial do aspecto não infeccioso da doença (Loew et al. 1969). Por vários anos, o diagnóstico da PEM foi realizado baseado nos sinais clínicos e resposta ao tratamento com tiamina, pois, além de não se conhecer a etiologia, as lesões de PEM não caracterizavam uma única doença. Algumas hipóteses associadas ao metabolismo da 
tiamina foram estabelecidas, como a descrita por Edwin \& Jackman (1973), que demonstraram que a PEM no Reino Unido estava associado com altos níveis de tiaminase ruminal e baixos níveis de tiamina no cérebro e fígado, sendo identificados como organismos produtores das tiaminases, o Clostridium sporogenes (Shreeve \& Edwin 1974) e o Bacilus sp (Morgan \& Lawson 1974).

A tendência em se considerar a PEM como sendo uma desordem no metabolismo da tiamina ocorreu devido os resultados obtidos por Edwin \& Jackman (1973) e também ao sucesso terapêutico da tiamina na recuperação de alguns animais doentes (Davis, 1965). Entretanto, este efeito terapêutico não é exclusivo de animais com PEM, pois, Copoock et al. (1991) e Dey et al. (1995) demonstraram resposta positiva da administração da tiamina em animais com encefalopatia devido a intoxicação por chumbo.

$\mathrm{Na}$ literatura internacional a principal causa de PEM relatada tem sido a intoxicação por enxofre (Raisbeck 1982, Gunn et al. 1987, Gooneratne et al. 1989, Sager et al. 1990, Hamlen et al. 1993, Jeffrey et al. 1994, McAllister et al. 1997, Loneragan et al. 1998, Gould 1998, 2000, Niles et al. 2000, Gould et al. 2001, Loneragan et al. 2001, Niles et al. 2002, Haydock 2003, Loneragan et al. 2005, Kul et al. 2006, Dewhurst et al. 2007, McKenzie et al. 2009). Outras etiologias descritas foram deficiência da tiamina (Jensen et al. 1956), intoxicação por sal associada à privação de água (Trueman \& Clague 1978, Osweiler et al. 1995), intoxicação por chumbo (Christian \& Tryphonas 1971), ingestão de melaço (Mella et al. 1976) e ingestão de plantas ricas em tiaminases (Pritchard \& Eggleston 1978) e infecção por herpesvírus bovino 5 (BoHV-5) (Perez et al. 2003).

No Brasil, existem relatos de ocorrência de surtos de PEM nos bovinos ocasionado por intoxicação por sal associada à privação de água (Lemos et al. 1997, Nakazato et al. 2000), intoxicação por chumbo (Lemos et al. 2004, Traverso et al. 2004), forma aguda da intoxicação por Phalaris spp. (Souza \& Irigoven 1999) e infecção por BoHV-5 (Salvador et al. 1998, Sanches et al. 2000, Claus et al. 2002, Colodel et al. 2002, Elias et al. 2004, Riet-Correa et al. 2006, Barros et al. 2006, Mendes et al. 2007, Rissi et al. 2006, 2007, 2008, Lunardi et al. 2009). O diagnóstico de PEM 
associado com distúrbio no metabolismo da tiamina (Santos et al. 1983, Gonçalves et al. 2001, Mendes et al. 2007), intoxicação por enxofre (Traverso et al. 2001, Sant Ana et al. 2009b) e alterações bruscas na dieta (Moro et al. 1994) foram estabelecidos correlacionando dados epidemiológicos, sinais neurológicos, achados histopatológicos e/ou resposta favorável à terapia com tiamina (diagnostico terapêutico), sendo as etiologias determinadas a partir de suposições, não sendo confirmadas laboratorialmente.

Considerando as diversas causas da PEM e a semelhança clínica entre elas (Claus et al. 2002, Elias et al. 2004, Barros et al. 2006), o diagnóstico ante-mortem é difícil de ser estabelecido, visto que essas enfermidades possuem sinais clínicos semelhantes. Desta forma, os métodos laboratoriais são de importância fundamental para o diagnóstico diferencial entre os agentes etiológicos da PEM.

A literatura nacional é escassa em relação às alterações hematológicas e liquóricas e valores da dosagem de sulfeto de hidrogênio ruminal como métodos complementares que possam auxiliar no diagnóstico diferencial da PEM causada pela ingestão excessiva de enxofre ou pelo BoHV-5.

O objetivo da tese foi de verificar os achados clínicos e laboratoriais da PEM em bovinos ocasionado pela ingestão de dieta com alto teor de enxofre ou pelo BoHV-5.

As atividades experimentais tiveram início em agosto de 2007 com grupo experimental constituído por dois bezerros Nelore suplementados com feno e intoxicado com sulfato de amônio, por via oroesofágica, totalizando o consumo de $1 \%$ de enxofre na matéria seca. Os animais vieram a óbito em intervalo inferior a sete dias apresentando alterações respiratórias e entéricas, mas não sendo observados sinais evidentes de encefalopatia.

Em junho de 2008 foi realizado em Campo Grande-MS, o II Encontro Nacional de Diagnóstico Veterinário (ENDIVET) onde apresentamos resumo com os resultados clínicos e laboratoriais dos dois bezerros intoxicados com enxofre a $1 \%$ na matéria seca. No evento encontramos o professor Daniel Gould da Universidade do Colorado que ficou bastante surpreso 
com os resultados do protocolo experimental com os bezerros Nelore. Na ocasião, discutiu-se a possibilidade do metabolismo do enxofre ser diferente entre os Bos taurus e o Bos indicus, podendo interferir na fisiopatogenia da enfermidade e, consequentemente, na manifestação clínica. Desta forma, a sugestão dada pelo referido professor foi utilizar protocolo descrito por Sager et al. (1990) utilizando bezerros Nelore.

No segundo semestre de 2008 foi realizado dois grupos experimentais sendo que quatro bovinos da raça Nelore ingeriram ração sem sulfato de sódio, enquanto seis consumiram ração com sulfato de sódio. Apesar de estabelecermos as mesmas condições do protocolo experimental descrito por Sager et al. (1990), não conseguimos induzir PEM nos bovinos da raça Nelore porque a ingestão da ração foi extremamente baixa, com níveis de 1 a 1,75\% de consumo por peso vivo. Na literatura pesquisada utilizando este protocolo, os consumos dos animais foram em torno de $2,5 \%$ do peso vivo.

Discutindo a questão da baixa ingestão da ração pelos bovinos da raça Nelore com professores de Nutrição Animal do Departamento de Melhoramento e Nutrição Animal da Faculdade de Medicina Veterinária e Zootecnia da Universidade Estadual Paulista "Júlio de Mesquita Filho" (FMVZ/UNESP/Botucatu), os mesmos afirmaram que possivelmente o problema estava associado com particularidades nutricionais correlacionadas com a raça Nelore. $\mathrm{O}$ fato de a ração possuir altos níveis de energia e proteína associado com a ausência de fibra efetiva poderia esta limitando o consumo.

Outro fator negativo observado foi à dificuldade de manejo dos bovinos da raça Nelore. Mesmo realizando uma adaptação com 14 dias no feno, foi extremamente difícil realizar os exames clínicos e laboratoriais propostos. Inicialmente as colheitas de amostras de sangue e do fluido ruminal, além das dosagens de gás sulfídrico ruminal, foram planejadas de serem realizadas com intervalos de 72 em 72 horas. Mas, este manejo ocasionou intenso estresse nos animais, inclusive alguns bovinos ficaram até dois dias sem ingerir a ração. 
Considerando que os artigos de indução de PEM por ingestão excessiva de enxofre foram realizados em bovinos Bos taurus optou-se por repetir o protocolo descrito por Sager et al. (1990), mas com bezerros mestiços leiteiros e fornecendo dieta contendo $0,52 \%$ de enxofre na matéria seca (segundo capítulo da tese).

Outro experimento realizado foi avaliação da concentração do sulfeto de hidrogênio ruminal utilizando tubos colorimétricos em bovinos Nelore sadios criados extensivamente visando fornecendo dados técnicos para que diante de um surto de PEM em bovinos a campo seja possível comparar os valores de sulfeto de hidrogênio ruminal com os obtidos na referida pesquisa (anexos da tese).

Além destes experimentos, foi realizado comparação dos parâmetros citológicos e bioquímicos do líquido cefalorraquidiano (LCR) coletado em dois diferentes momentos de bovinos sadios. O objetivo do presente trabalho foi verificar se uma primeira coleta de LCR em bovinos clinicamente sadios interfere nos resultados das análises citológicas e bioquímicas de uma segunda amostra obtida com intervalo de 96 horas (anexos da tese). Os resultados desta pesquisa forneceram informações importantes para o delineamento do intervalo de tempo entre as coletas do LCR do último grupo experimental da tese, onde se avaliou aspectos clínicos e laboratoriais da indução da necrose cerebrocortical em bovinos pela inoculação experimental com BoHV-5 (terceiro capítulo da tese). 


\section{REVISÃO DE LITERATURA}

\subsection{Polioencefalomalacia ocasionada por ingestão excessiva de enxofre}

O termo PEM foi inicialmente utilizado para designar uma doença específica de ruminantes caracterizada por necrose da substância cinzenta do cérebro (Jensen et al. 1959) e causada por deficiência de tiamina (Edwin \& Jackman 1973). Entretanto, estudos realizados nos anos seguintes demonstraram que nem todos os casos de PEM em ruminantes estavam associados aos distúrbios da

tiamina e que várias outras etiopatogenias estavam envolvidas no desenvolvimento desta lesão (Gould et al. 1997, Gould 1998, 2000, Burgess 2008).

A associação entre dietas com alto teor de enxofre e a ocorrência de PEM em bovinos foi confirmada por vários autores, tanto na forma de surtos (Coghlin 1944, Davies 1965, Dickie et al. 1979, Raisbeck 1982, Harris 1987, Hamlen et al. 1993, Jeffrey et al. 1994, McAllister et al. 1997, Niles et al. 2000, Traverso et al. 2001, Haydock 2003, Kul et al. 2006, Mckenzie et al. 2009) ou por induções experimentais (Mella et al. 1976, Sager et al.1990, Gould et al. 1991, McAllister et al. 1992, Cummings et al. 1995, Gould et al. 1997, Niles et al. 2002, Cunha et al. 2008).

\subsubsection{Fontes de enxofre}

As principais fontes de enxofre relatadas que ocasionaram PEM, tanto na forma de surtos ou por indução experimental, foram: melaço (Mella et al. 1976, Gooneratne et al. 1989), aditivos alimentares como o gipso (Raisbeck 1982), flor de enxofre (Gunn et al. 1987), sulfato de sódio (Sager et al. 1990, Gould et al. 1991, Gould et al. 1997), sulfato de amônio (Jefrey et al. 1994, Cunha et al. 2008), água com elevado teor de sulfatos (Hamlen et al. 1993, McAllister et al. 1997), 
associações entre diferentes fontes da dieta (feno e melaço) e água (Loneragan et al. 1998), subprodutos de grãos (Niles et al. 2000, Niles et al 2002), cevada (Kul et al. 2006) e ingestão de gramíneas da família Brassicaceae (Mckenzie et al. 2009).

Plantas como a alfafa podem conter elevado teor de enxofre naturalmente (Olkowski 1997) ou devido à utilização de fertilizantes (sulfato de amônio) que contenham na constituição sulfatos (Hardt et al. 1991). Trabalhos como de Spears et al. (1985) e Buttrey et al. (1986) mostraram que a fertilização do solo com sulfato de amônio melhorou a digestibilidade da fibra em detergente ácido e da fibra em detergente neutro das forragens cultivadas nestes solos, quando fornecida aos ruminantes. Os microrganismos do rúmen podem incorporar enxofre inorgânico em compostos orgânicos, especialmente aminoácidos sulfurados (Kandylis 1984).

\subsubsection{Epidemiologia}

\subsubsection{Surtos}

Coghlin (1944) descreveu surto de intoxicação por enxofre em bovinos ocasionado pela adição de enxofre na silagem. Esta prática era comum entre os produtores e tinha como objetivo prevenir infestação por piolho. O diagnóstico foi realizado principalmente pela identificação do odor desagradável do sulfeto de hidrogênio ruminal (gás sulfídrico ou $\mathrm{H}_{2} \mathrm{~S}$ ), que foi facilmente detectado nos currais e ao realizar a inspeção da boca dos animais afetados.

Raisbeck (1982) realizou estudo retrospectivo dos casos de PEM diagnosticadas no Laboratório de Diagnóstico de Medicina Veterinária da Universidade do Missouri nos Estados Unidos da América (EUA), referente aos anos de 1979 e 1980. Durante este período, o referido autor observou a ocorrência de PEM em 18 de 21 rebanhos alimentados com ração contendo elevados teores de sulfato. Uma prática comum identificada em muitas propriedades foi à inclusão 
de $2 \%$ de sulfato inorgânico (gipso) na ração com objetivo de limitar o consumo, ocasionando PEM após um período de uma a quatro semanas de introdução deste aditivo. Em outro relato, 30 vacas de um lote de 300 animais criados extensivamente, apresentaram sinais de PEM após serem suplementadas com ração contendo 1,5\% de sulfato inorgânico. Em um rebanho de 1.100 bovinos confinados, foram detectados sinais clínicos de PEM em 400 animais após duas semanas do fornecimento de uma ração em que adicionavam 85 gramas de sulfato de amônio por animal. Este estudo retrospectivo foi importante porque sugeriu uma possível relação do enxofre com a ocorrência de PEM, estimulando diversos pesquisadores (Gooneratne et al. 1989, Sager et al. 1990, Gould et al. 1991, Gould et al. 1997) a elaborarem protocolos de indução experimental para comprovar esta hipótese.

Gunn et al (1987) descreveram óbito de 14 vacas holandesas após a adição acidental de flor de enxofre na ração de 120 vacas Holandesas, estimando o consumo de enxofre de 0,85 a 3,8 g de enxofre por $\mathrm{Kg}$.

Jefrey et al. (1994) relataram surtos de PEM em ovinos e bovinos em cinco fazendas associados com a ingestão de ração contendo sulfato de amônio. A ração era fornecida por duas diferentes empresas que substituíram o bicarbonato de amônio, normalmente utilizado para acidificar urina e evitar urolitíase, por sulfato de amônio. Entretanto, ao realizar esta substituição para reduzir custos na produção, aumentaram o teor de enxofre na ração, ocasionando a PEM em alguns animais.

Hamlen et al. (1993) descreveram surto de PEM em 11 bovinos a pasto de um lote de 110 ocasionado por elevada quantidade de sulfato de sódio (7200 ppm) na água. Em uma investigação de surto de PEM em bovinos confinados consumindo água contendo aproximadamente $2500 \mathrm{mg} / \mathrm{L}$ de sulfato, a maioria dos casos de PEM ocorreu entre o $15^{\circ}$ e $35^{\circ}$ dia pós entrada no confinamento e nos meses mais quentes do ano (McAllister et al. 1997). 
Loneragan et al. (1998) relataram associação entre o consumo excessivo de enxofre e o aumento da concentração de sulfeto de hidrogênio ruminal de bovinos de corte recém desmamados com PEM. As determinações da concentração do gás sulfidrico ruminal em duas novilhas, que não apresentavam sinais clínicos, foram de 6.900 e 13.500 ppm, valores acima do normal (500 ppm). Após análise da concentração do enxofre na água (664 ppm de enxofre) e na dieta, composta basicamente por feno de "tristle" Canadá (1.699,33 ppm de enxofre) e suplemento mineral com melaço (6.637 ppm de enxofre), conclui-se que os bovinos estavam ingerindo $0,9 \%$ de enxofre na matéria seca.

Segundo Gould (2000) nas regiões centro-norte e oeste dos EUA, a água contém elevada quantidade de sulfato. $\mathrm{O}$ sal do sulfato precipita quando ocorre a evaporação da água. A concentração do sulfato na água pode aumentar quando a água evapora nas estações do ano mais quentes. O consumo de água pelos bovinos é dependente da temperatura ambiental e aumenta significativamente em elevadas temperaturas. Em estações climáticas quentes, o consumo de enxofre oriundo da água pode estar elevado porque ocorre concomitantemente o aumento do consumo de água e da concentração do sulfato na água podendo ultrapassar os limites toleráveis estabelecidos pelo Klasing et al. (2005).

Niles et al. (2000) descreveram três surtos em bezerros confinados que receberam subprodutos de milho (farelo de glúten de milho) e suplementos contendo melaço. Nos EUA a utilização de subprodutos da agroindústria tem sido frequente porque proporcionam ganho de peso satisfatório com baixo custo.

Kul et al. (2006) relataram achados clínicos e histopatológicos de PEM em bovinos após mudança brusca da dieta em duas fazendas contendo 2.750 bovinos tipo leite e 2.300 tipo corte. Os principais achados clínicos incluíram andar em círculos, hipersensibilidade, salivação excessiva, hipermetria, ataxia, amaurose e morte. Os animais tratados não responderam a injeção com tiamina. O teor de enxofre total da dieta contendo malte de cevada foi estimado em $0,45 \%$. 
A PEM tem sido também descrita em bovinos pastejando plantas acumuladoras de enxofre, como Kochia scoparia (Dickie et al. 1979), Chenopodium spp. (Gould 2000), brotos de cevada (Hordeum vulgare) (Kul et al. 2006), Descurainia pinnata (Afip 2005-2006), Brassica oleracea (Hill \& Ebbett 1997), B. rapa e B. napus (Gould 2000).

McKenzie et al. (2009) relataram dois surtos de PEM na Austrália. No primeiro, oito de 20 novilhas Aberdeen Angus morreram enquanto pastavam em um piquete contendo $60 \%$ de Sisybrium irio e $40 \%$ de Capsella bursapastoris. No segundo surto, dois bovinos adultos de um lote de 150 vieram a óbito após serem mantidos em um pasto contendo exclusivamente Raphanus raphanistrum. Foi calculado o teor de enxofre nas plantas e na fonte hídrica, obtendo respectivamente, $0,62 \%$ e $1,01 \%$ de enxofre na matéria seca. Estas plantas são classificadas como crucíferas (Brassicaceae) e possuem a capacidade de acumular enxofre. Mas, nenhuma dessas plantas acumuladoras de enxofre (citadas acima) tem sido associada a surtos de PEM em ruminantes no Brasil (Sant'Ana et al. 2009b).

Traverso et al. (2001) relataram surto de PEM por enxofre em dois terneiros de 6 meses de idade em uma propriedade com 35 vacas, que recebiam pasto verde, silagem e ração comercial na qual era adicionado enxofre pelo proprietário aproximadamente duas vezes por semana em dose que não soube especificar. No Rio Grande do Sul não é raro encontrar-se produtores que adicionam enxofre ventilado na ração concentrada dos animais. Acreditam que esta suplementação melhore o desempenho dos animais e os proteja do ataque de ectoparasitas. 


\subsubsection{Indução experimental}

Mella et al. (1976) ocasionaram PEM fornecendo uma mistura de melaço e uréia em bovinos da raça Holandesa. A indução experimental foi realizada fornecendo capim napier durante três dias, seguido por redução gradativa de $0,5 \mathrm{Kg} / \mathrm{cabeça/dia} \mathrm{do} \mathrm{quarto} \mathrm{ao} \mathrm{décimo} \mathrm{dia,} \mathrm{de} \mathrm{tal} \mathrm{forma}$ que do $11^{\circ}$ ao $40^{\circ}$ dia os bovinos foram alimentados exclusivamente com melaço e uréia. A partir do $16^{\circ}$ dia os animais começaram a apresentar sinais neurológicos, sendo que no final do experimento todos foram sacrificados e os achados histopatológicos confirmaram a presença de lesões compatíveis com PEM. De acordo com Gould (2000), esse foi o primeiro relato de PEM ocasionado por enxofre, pois, o melaço contem $0,45 \%$ de enxofre na matéria seca, teor considerado alto por Klasing et al. (2005).

A partir do estudo retrospectivo de Raisbeck (1982) e de um surto de PEM na Nova Zelândia, Gooneratne et al. (1989) desenvolveram estudo para monitorar os níveis de tiamina e do cobre e avaliar interações entre fatores nutricionais que poderiam favorecer a ocorrência da PEM. A dieta básica era constituída por forragem, cevada e farinha de canola totalizando $0,38 \%$ de enxofre na matéria seca. Os resultados indicaram que a combinação do consumo de elevado teor de enxofre e baixo de cobre foi responsável pela depleção da tiamina no sangue e cobre plasmático. Além disso, os autores sugeriram que altas concentrações de sulfeto no rúmen poderiam estar atuando como antagonista da tiamina.

Sager et al. (1990) estabeleceram protocolo de indução experimental de PEM por enxofre (sulfato de sódio) em bezerros fornecendo ração com carboidrato de alta fermentação, baixa quantidade de fibra e composição variada de cobre e molibdênio. Duas rações foram formuladas, uma com níveis normais e outra com baixos teores de cobre, sendo que ambas induziram PEM. A dieta experimental continha aproximadamente $0,26 \%$ de enxofre na matéria seca. Os animais 
suplementados com dieta rica em enxofre desenvolveram PEM e foram detectadas elevadas concentrações de sulfeto ruminal e da tiamina plasmática e ruminal.

A pesquisa desenvolvida por Sager et al. (1990) apresentou resultados das concentrações da tiamina plasmática e ruminal divergentes das realizadas por Loew et al (1975) e Gooneratne et al. (1989). Para os referidos autores, esta variação pode ser justificada pelo fato das pesquisas terem utilizado diferentes metodologias de avaliação da tiamina. Sager et al. (1990) utilizaram cromatografia líquida de alta performance, que permite a separação de compostos que possuem as mesmas características fluorescentes, enquanto Loew et al. (1975) empregaram método de detecção fluométrica, que mensura todos os componentes fluorescentes a partir do momento que são excitados.

A associação do enxofre com a PEM continuou sendo investigada por Gould et al. (1991), que utilizaram protocolo de indução desta doença semelhante ao descrito por Sager et al. (1990), fornecendo para os bovinos $0,36 \%$ de enxofre na matéria seca. A elevada concentração de sulfeto ruminal coincidiu com o aparecimento dos sinais neurológicos, sugerindo que este composto estava envolvido na patogenia da PEM por enxofre.

Para melhor compreensão da PEM ocasionada por ingestão excessiva de enxofre, Cummings et al. (1995) avaliaram alterações microbiológicas ruminais associadas com a produção de sulfeto de hidrogênio ruminal em novilhas submetidas ao mesmo protocolo de indução descrito por Sager et al. (1990). Para estes autores, a capacidade de produção de sulfeto de hidrogênio ruminal a partir do sulfato no fluido ruminal "in vitro" foi significativa somente após 10 a 12 dias de suplementação com dieta rica com enxofre, coincidindo com o aparecimento dos sinais neurológicos. A baixa capacidade de produção do sulfeto de hidrogênio ruminal observada no início do fornecimento da dieta experimental rica em sulfato sugeriu que os microrganismos ruminais necessitam de um período de adaptação para poderem produzir quantidades tóxicas de sulfeto. 
As pesquisas desenvolvidas por Gould et al. (1991) e Cummings et al. (1995) indicaram a participação do sulfeto de hidrogênio ruminal na patogenia da PEM ocasionada por ingestão excessiva de enxofre, mas para detecção deste composto foi utilizado cromatografia líquida de alta performance, não sendo um teste laboratorial comumente utilizado na rotina devido principalmente ao custo por amostra. Desta forma, Gould et al. (1997) adaptaram uma técnica de detecção de sulfeto de hidrogênio ruminal utilizando tubos colorimétricos, possibilitando a quantificação deste composto nas fazendas e de forma imediata.

Loneragan et al. (2001) forneceram água com variados teores de enxofre (125, 250, 500, 1.000 e $2.000 \mathrm{mg} / \mathrm{L}$ ) para novilhas confinadas e avaliaram a performance, o consumo de água e as característica das carcaças. O aumento da concentração de enxofre na água reduziu de forma significativa a performance (ganho de peso diário, consumo de matéria seca e peso final) e o rendimento de carcaça das novilhas confinadas.

Niles et al. (2002) utilizaram 14 novilhas para avaliar o efeito de três diferentes concentrações de enxofre na ração. A alimentação fornecida era constituída por $70 \%$ de farelo de glúten de milho (subproduto de grãos) e $30 \%$ de casca de algodão. Como fonte de enxofre adicionou-se o sulfato de sódio na dieta basal constituindo os tratamentos designados como nível moderado (3.860 ppm de enxofre), moderamente alto (5.540 ppm de enxofre) e alto (7.010 ppm de enxofre). Sinais clínicos de PEM foram observados nos grupos classificados como moderamente alto e alto de ingestão de enxofre. Lesões microscópicas compatíveis de PEM foram observadas em todos os bovinos, inclusive no grupo que não apresentou sinais clínicos.

Loneragan et al. (2005) avaliaram o efeito da ingestão de água com alto teor de enxofre acrescentando sulfato na fonte hídrica em três diferentes concentrações $(125,500$ e $2.000 \mathrm{mg} / \mathrm{L})$ para novilhas confinadas e observaram aumento da produção de gás sulfídrico associado com maior ocorrência de PEM. 
No Brasil, Cunha et al. (2008) objetivando descrever os achados clínicos e laboratoriais causados pela intoxicação experimental por enxofre em bovinos Nelore induziram PEM fornecendo diariamente, por via nasoesofágica, enxofre a $1 \%$ da matéria seca.

\subsubsection{Fisiopatogenia}

O organismo animal contêm aproximadamente $0,2 \%$ de enxofre, podendo ser encontrado tanto na forma mineral como orgânica constituindo os aminoácidos sulfurados (cistina, cisteína e metionina) e vitaminas (tiamina e biotina) (Ortolani et al. 2001). A quantidade inadequada deste nas dietas pode prejudicar o metabolismo da microbiota ruminal, reduzindo a digestão de carboidratos dietéticos e o suprimento de aminoácidos para o metabolismo dos tecidos do hospedeiro. Tais mudanças causam a redução no consumo voluntário, no suprimento de energia e na taxa de síntese da proteína corporal (Weston et al. 1988).

O alto consumo de enxofre pode afetar os bovinos de duas formas. A primeira está correlacionada com a redução ruminal do enxofre que produz complexos intermediários com o cobre ocasionando redução na absorção e uso deste elemento (Gould et al. 2001). Essa deficiência de cobre secundária resultou em diminuição do desempenho dos bovinos (Loneragan et al. 2001). A segunda forma está associada à capacidade dos microrganismos ruminais em gerar sulfeto de hidrogênio, que aumenta sob condições de alto consumo de enxofre na alimentação, sendo os microrganismos redutores de sulfato responsáveis por este processo de conversão (Cunmmings et al. 1995).

Acredita-se que a base da patogenia da PEM por elevada ingestão de enxofre esteja associada com produção excessiva de sulfeto realizada pelas bactérias ruminais. As formas não reduzidas do enxofre como sulfato e enxofre elementar não são tóxicas, mas o sulfeto de hidrogênio e suas variações iônicas (sulfito) são substâncias altamente tóxicas (Kandylis 1983, Gould, 1998, 
2000, Burgess, 2008), que interferem na respiração celular (Kandylis 1984, Beauchamp et al. 1984) e favorecem a manifestação clínica da PEM.

A toxicidade do enxofre e de seus metabólitos como sulfetos e sulfitos, pode causar o desenvolvimento de lesões necróticas no encéfalo, mas dúvidas ainda persistem de como a quantidade de gás sulfídrico produzida no rúmen de bovinos submetidos à dieta com elevada quantidade de enxofre é suficiente para causar danos ou se um complexo metabólico não pode estar envolvido. A compreensão do mecanismo de eliminação do sulfito e sulfeto é fundamental para o esclarecimento da patogenia das lesões necróticas do encéfalo (Olkowski 1997).

Em ruminantes, o esquema de eliminação do sulfeto $\left(\mathrm{S}^{-2}\right)$ via processo oxidativo é importante, visto que neste processo o sulfito $\left(\mathrm{SO}_{3}{ }^{2-}\right)$ é um metabólito intermediário. O sulfito é um ânion nucleofílico relativamente forte que pode reagir com uma variedade de estruturas celulares e causar toxidade. Várias anormalidades cerebrais, incluindo processos degenerativos progressivos do cérebro foram observados em pacientes com deficiência de sulfito oxidase. $\mathrm{O}$ tecido do cérebro por conter altas concentrações de lipídeos torna-se mais vulnerável aos danos oxidativos. Assim, o cérebro possui elevadas taxas de metabolismo oxidativo e poucos mecanismos antioxidativos. Radicais derivados do sulfito podem ser formados pelas reações catalíticas da peroxidase e causar peroxidação lipídica e lesões nas membranas biológicas. Uma taxa insuficiente de oxidação do sulfito devido sobrecarga de enxofre e, subsequente acumulação deste metabólico no cérebro pode ser importante na patogênese das lesões necróticas no cérebro devido ingestão excessiva de enxofre (Olkowski 1997).

Nos ruminantes as formas do enxofre podem ser oxidadas para sulfatos ou reduzidas para sulfeto, processo este conhecido como ciclo do enxofre. Existem dois tipos de bactérias que reduzem sulfato: dissimilatórias e assimilatórias. As bactérias dissimilatórias usam enxofre como um receptor de elétrons e produzem sulfetos como um produto metabólico final necessário e as assimilatórias reduzem enxofre objetivando sintetizar aminoácidos que contenham enxofre. 
Produção e acúmulo excessivos de sulfeto no rúmen poderiam ser causados pela predominância de bactérias dissimilatórias ou por capacidade assimilatória insuficiente (Gould 2000).

O gás sulfídrico ou sulfeto de hidrogênio $\left(\mathrm{H}_{2} \mathrm{~S}\right)$ é um produto normal do metabolismo da microbiota ruminal (Kandylis 1983) e as bactérias do gênero Desulfovibrio e Desulfotomaculum são as responsáveis pela degradação do sulfato especialmente em sulfeto de hidrogênio, sendo este eructado ou absorvido ou usado na síntese da proteína microbiana (Gould 1998, 2000, Burgess 2008). A maioria do enxofre é reduzida em $\mathrm{H}_{2} \mathrm{~S}$ no rúmen. $\mathrm{O}$ sulfeto de hidrogênio absorvido é oxidado em sulfato no fígado e é distribuído para fluidos extracelulares. O sulfato é reciclado no rúmen pela saliva ou diretamente pelo intestino grosso (Kandylis 1983).

$\mathrm{O}_{2} \mathrm{~S}$ é rapidamente absorvido pela mucosa ruminal para a corrente sanguínea e se estiver em elevadas concentrações, inibe a função da anidrase carbônica, dopa oxidase, catalases, peroxidases, desidrogenases, ou seja, compromete diversos mecanismos de metabolismo oxidativo e de produção de ATP (Kung et al. 1998).

Nos ruminantes, $60 \%$ dos gases eructados podem ser inalados, favorecendo a exposição do trato respiratório ao gás sulfídrico durante episódios de produção patológica ruminal de sulfeto, podendo ocasionar pneumonia intersticial em bovinos (Kung et al. 1998).

Gould (2000) e Burgess (2008) enfatizaram que o odor de "ovo podre" produzido pela eructação do gás sulfídrico foi associado ao aparecimento da PEM em novilhas suplementadas com excesso de enxofre, estabelecendo uma correlação positiva entre a elevada concentração de gás sulfídrico no fluido ruminal e o aparecimento dos sinais clínicos da PEM induzida experimentalmente com dieta rica em enxofre. Desta forma, acredita-se que a PEM ocorra como consequência direta da ação do gás sulfídrico e não como resultado de neurotoxinas derivadas do rúmen associadas com alterações das condições ruminais (Gould 1998).

A produção de gás sulfídrico ruminal pode ser afetada pelo tipo de carboidrato, $\mathrm{pH}$ do fluido ruminal e concentração de determinados minerais da dieta. A fonte de carboidrato afeta o 
metabolismo microbiano e o pH do fluido ruminal. A concentração do gás sulfídrico no rúmen muda de acordo com o pH e condições que favoreçam acidificação do $\mathrm{pH}$ proporcionam aumento da concentração do gás sulfídrico ruminal (Gould 2000).

Uma interrelação entre enxofre, cobre e molibdênio foi primeiramente relatada por Dick \& Bull (1945) citados por McDowell (1992), mostrando que dietas com elevada concentração de molibdênio diminuem o acúmulo de cobre hepático, assim como os sulfatos inorgânicos tem efeito antagonista aos elementos cobre e molibdênio. Os minerais como zinco, cobre, ferro e molibdênio podem interferir na produção patológica do gás sulfídrico ruminal. O molibdênio, cobre e enxofre combinam formando o cobre-tiomolibdato que é insolúvel (Burgess 2008). O cobre, zinco e ferro, formam sal insolúvel com o sulfeto. A formação de sulfeto diminui a absorção da maioria dos minerais, sendo que quantidades extras de cobre, zinco e ferro podem ser necessários para bovinos que consomem elevada quantidade de enxofre (Gould 1998). Ingestões de elevadas quantidades de enxofre diminuem a biodisponibilidade de cobre. $\mathrm{O}$ molibdênio pode inibir a ação das bactérias redutoras de enxofre (Gould 2000).

\subsubsection{Sintomatologia Clínica}

Existem duas formas da PEM ocasionada por enxofre: subaguda e aguda. A forma subaguda desenvolve dentro de horas a dias. Os animais acometidos se isolam do rebanho e apresentam alguns dos seguintes sinais: anorexia, incoordenação, hipermetria, hiperestesia, diarréia e tremores musculares, movimentos involuntários das orelhas ou contrações dos músculos faciais, nistagmo, estrabismo ou desvio da cabeça. Os sinais clínicos progridem para cegueira cortical com diminuição do reflexo de ameaça, compressão da cabeça contra parede, opistótono, estrabismo dorsomedial, miose, disfagia e ptialismo. A maioria dos animais responde de forma favorável a terapia quando apresentam esta forma clínica. Entretanto, os sinais podem evoluir para decúbito, 
convulsões tônico-clônicas e morte (Kandylis 1983, Olkowski 1997, Gould 2000, Cebra \& Cebra 2004, Radostitis et al. 2007, Burgess 2008). Apesar da diminuição de reflexo de ameaça visual, o reflexo pupilar está presente devido à cegueira originar-se da lesão do córtex occipital (Mendes et al. 2007).

A forma aguda manifesta com cegueira, decúbito e com episódios de convulsões tônicoclônicos. $\mathrm{O}$ animal pode evoluir para estado comatoso ou pode ser encontrado morto. O prognóstico é desfavorável para os animais que apresentam a forma aguda ou os sinais mais graves da subaguda. Alguns animais que recuperam podem apresentar sequelas como baixa performance, ataxia e cegueira (Kandylis 1983, Olkowski 1997, Gould 2000, Cebra \& Cebra 2004, Radostitis et al. 2007, Burgess 2008).

Dentre os sinais clínicos deve-se destacar a cegueira, que foi identificada em todos os animais acompanhados em um estudo no Estado de São Paulo (Gonçalves et al. 2001). Apesar de a lesão afetar inicialmente o córtex cerebral causando cegueira e outros sinais cerebrais, pode-se observar estrabismo e nistagmo devido à compressão do tronco encefálico e opistótono por compressão do cerebelo (Riet-Correa et al. 2007).

Um achado clínico bastante relatado e facilmente identificado é o odor de ovo em putrefação exalado pelos animais intoxicados, ocorrendo devido à produção excessiva de sulfeto de hidrogênio ruminal (Gould 2000, Cebra \& Cebra 2004, Radostitis et al. 2007, Burgess 2008).

\subsubsection{Diagnóstico Diferencial}

O diagnóstico diferencial de PEM ocasionada por enxofre deve incluir as outras causas de necrose laminar do córtex cerebral como distúrbio do metabolismo da tiamina, intoxicação por sal associada à privação de água, intoxicação por chumbo, assim como as demais causas de encefalopatias que acometem os bovinos, como a raiva. 


\subsubsection{Hemograma e bioquímica sérica}

Avaliações hematológicas não apresentam alterações significativas na PEM ocasionada por enxofre (Olkowski 1997) e por tiaminases (Radostitis et al. 2007).

Na PEM ocasionada pela inoculação experimental por BoHV-5, Isernhagen (2005) relatou que a avaliação hematológica não apresentou nenhuma variação significativa para as variáveis do eritrograma, enquanto os resultados do leucograma, por outro lado, caracterizaram, nos bezerros com encefalopatia, tendência à elevação dos leucócitos acompanhada por aumento significativo dos neutrófilos segmentados circulantes, mas possivelmente associado com estresse. Lisboa et al. (2009) observaram leucocitose com neutrofilia em alguns animais infectados naturalmente por BoHV-5, mas identificaram pneumonia simultaneamente com meningoencefalite.

O saturnismo é uma intoxicação que ocorre em virtude de ingestão acidental de quantidade tóxica de chumbo, especialmente por bovinos jovens. A curiosidade natural, hábito de lamber e pouca seletividade oral dos bovinos fazem de qualquer material disponível (baterias, pilhas), uma possível fonte de intoxicação. Os achados hematológicos incluem anemia regenerativa, presença de pontilhado basofílico eritrocítico e, em alguns casos aumento na concentração de porfirina eritrocitária sanguínea (Radostitis et al. 2007).

A estimativa dos níveis séricos de chumbo é geralmente utilizada para determinar os valores desse elemento nos tecidos do animal. Os níveis sanguíneos considerados normais são de 0,05 a 0,25 ppm, enquanto nos bovinos intoxicados são de 0,36 a 1 ppm. As concentrações de chumbo no sangue não devem ser utilizadas como único critério de diagnóstico, pois flutuam marcadamente após ingestão desse metal pesado e não permitem avaliar exposições prolongadas (Radostitis et al. 2007). A confirmação da intoxicação pode ser feita pela determinação dos níveis de chumbo em fragmentos de tecidos renal (>25 ppm) e hepático ( $>10 \mathrm{ppm})$ de animais afetados (Riet-Correa et al. 2007). 
Em dois surtos de intoxicação de chumbo diagnosticados no Brasil, os níveis de chumbo no rim e no fígado dos bovinos afetados foram, respectivamente $2.037 \mathrm{ppm}$ e $110 \mathrm{ppm}$ (Traverso et al. 2004) e de 39 ppm e 51,7 ppm (Lemos et al. 2004).

\subsubsection{Determinação da tiamina sérica}

Diversas pesquisas não foram capazes de demonstrar que os níveis de tiamina eram reduzidos nos tecidos e no fluido ruminal de animais acometidos por PEM (Loew et al. 1970, Mella et al. 1976, Sager et al. 1990, Gould et al. 1991), inclusive a concentração sanguínea da tiamina permaneceu elevada durante aparecimento de sinais neurológicos em ovinos submetidos a indução experimental de PEM (Gooneratne et al. 1989). A atividade da trancetolase sanguínea e das tiaminases gastrointestinais pode ser alterada de forma inespecífica e em condições diversas além da PEM (Loew et al. 1970).

Goud et al (1991) questionaram a participação da tiamina na patogênese da PEM pois conseguiram induzir experimentalmente necrose cerebrocortical em bovinos suplementados com excesso de enxofre sem observar alterações significativas no nível da tiamina no sangue, líquido cefalorraquidiano, cérebro e fígado.

\subsubsection{Análise do líquido cefalorraquidiano}

A análise do LCR é um exame complementar útil e rápido para o diagnóstico etiológico das doenças do SNC. A contagem total e diferencial das células e a concentração de proteína podem fornecer informações para detecção de alterações inflamatórias, confirmando que existe uma anormalidade neurológica e, em alguns casos, podendo definir a etiologia do processo (D’Ângelo et al. 2009). 
Nas encefalites virais um achado comum na análise do LCR é a pleocitose mononuclear e/ou aumento na concentração de proteínas (Radostitis et al. 2007, Lisbôa et al. 2009). Isernhagen (2005) avaliou aspectos da evolução clínica e do diagnóstico da meningoencefalite herpética em bezerros experimentalmente infectados com o BoHV-5 e concluiu que a pleocitose mononuclear é uma alteração marcante no líquor e, quando presente, pode auxiliar no diagnóstico ante-mortem.

A análise do líquor da PEM ocasionada por enxofre ou chumbo apresenta as mesmas características, com pleocitose e aumento da concentração das proteínas (Cebra \& Cebra 2004). Valores acima de $160 \mathrm{mEq} / \mathrm{L}$ de sódio no LCR são sugestivos de intoxicação por sal em bovinos (Loneragan et al. 2005).

\subsubsection{Achados de necropsia e histopatológico}

Os achados de necropsia da PEM variam de acordo com a severidade e duração do quadro clínico (Sant'Ana et al. 2009ab), podendo estar ausentes quando a evolução for aguda (Nakazato et al. 2000). Na fase inicial a tumefação do encéfalo pode não ser facilmente identificada, mas com agravamento do edema, o encéfalo pode se deslocar caudalmente (herniação) do bulbo e do cerebelo no sentido do forame magno. Nos casos mais avançados, pode ser visualizado achatamento das circunvoluções cerebrais, áreas amareladas, amolecidas, gelatinosas e deprimidas, hemorragias meníngeas e subcorticais, ou até mesmo, cavitações preenchidas por líquido amarelo. Essas alterações ocorrem especificamente na substância cinzenta do encéfalo, que é mais bem observada na superfície de corte (Sant'Ana et al. 2009a). As áreas mais afetadas geralmente correspondem aos giros corticais dorsais e estão localizadas principalmente nos sulcos das circunvoluções (Nakazato et al. 2000, Lemos 2005).

No exame histopatológico, nos casos agudos há necrose laminar e segmentar dos neurônios corticais do telencéfalo, caracterizada por encarquilhamento e eosinofilia citoplasmática, 
cromatólise e picnose nuclear (neurônios vermelhos) (Sant'Ana et al. 2009ab). Edema também é uma alteração comum e consiste de aumento dos espaços perineuronais e perivasculares e formação de numerosos vacúolos no neurópilo (espongiose). A progressão dessa lesão pode, em alguns casos, formar fendas entre as camadas de neurônios corticais ou entre as substâncias cinzenta e branca (Barros et al. 2006, Sant'Ana et al. 2009b)

Os achados de necropsia no encéfalo de bovino intoxicados por chumbo podem ser semelhantes aos descritos na PEM ocasionados pelas outros fatores já descritos, exceto o fato de que as áreas de malacia ocorrem preferencialmente no topo dos giros cerebrais (Lemos et al. 2004, Traverso et al. 2004). Christian \& Tryphonas (1971) relataram que dependendo da evolução clínica, as lesões podem ser mais evidentes em determinadas porções do SNC. A degeneração epitelial dos túbulos renais associada a corpúsculos de inclusão eosinofílicos intranucleares alcoolácidos resistentes é também citado por Traverso et al. (2004) como um achado frequente em bovinos intoxicados.

$\mathrm{Na}$ intoxicação experimental por Phalaris spp., as alterações macroscópicas foram observadas apenas no encéfalo e eram caracterizadas por focos de coloração verde-azulada no tálamo, mesencéfalo e medula oblonga. Microscopicamente observou-se pigmento granular marrom-amarelado no citoplasma de neurônios das regiões macroscopicamente afetadas (Souza \& Irigoyen 1999).

Na intoxicação por sal, os achados de necropsia são caracterizados por hemorragia subdural, congestão dos vasos meníngeos ou diminuição de consistência da porção caudal do cérebro (Sant'Ana et al. 2009b). Lemos et al (1997) relataram que além da necrose neuronal laminar do córtex telencefálico, alguns casos de intoxicação por sal apresentaram acúmulos de eosinófilos nos espaços de Virchow-Robin, nas regiões submeníngeas e, menos comumente, no neurópilo.

A encefalite por BoHV-5, devido à semelhança dos sinais clínicos e, principalmente pelas lesões histológicas caracterizadas por extensas áreas de malacia no córtex cerebral de animais 
afetados, pode ser muitas vezes confundida com PEM ocasionada por ingestão excessiva de enxofre (Riet-Correa et al. 2007). Os achados são caracterizados por infiltrado inflamatório perivascular linfoplasmocitário ou misto nos espaços de Virchow-Robin ou ao redor de vasos meníngeos, infiltração difusa de neutrófilos no neurópilo, necrose neuronal, caracterizada por encolhimento e eosinofilia do citoplasma e núcleo picnótico (Salvador et al. 1998, Colodel et al. 2002, Elias et al. 2004, Rissi et al. 2006).

\subsubsection{Diagnóstico virológico do BoHV-5}

As técnicas confirmatórias do BoHV-5 incluem o isolamento do vírus do encéfalo ou de secreções nasais (d'Offay et al. 1995), identificação do agente por anticorpos monoclonais (Roehe et al. 1997, Souza et al. 2002, Kunrath et al. 2004, Oldoni et al. 2004), técnicas moleculares como a PCR (Ashbaugh et al. 1997, Alegre et al. 2001, Claus et al. 2005, 2007, Del Médico Zajac et al. 2009) e imunoistoquímica (Ordónez 2003, Hübner et al. 2005, De Paula et al. 2005).

\subsubsection{Diagnóstico Definitivo}

O diagnóstico da PEM atribuídos a dietas ricas em enxofre deve ser realizado com base na epidemiologia, quadro clínico, na dosagem do teor de gás sulfídrico ruminal, do enxofre na dieta e pelas alterações macroscópicas e microscópicas no SNC (Gould 2000; Radostitis et al. 2007, Burgess 2008, Sant'Ana et al. 2009ab).

Para estabelecer o diagnóstico da PEM ocasionada por enxofre devem-se realizar as dosagens dos teores de enxofre da água e da pastagem consumida pelos animais, e somá-las a quantidade do elemento ingerida ração e na mistura mineral, verificando se o total consumido não está acima dos 4000 ppm de enxofre na matéria seca recomendada (Klasing et al. 2005). Para 
Olkowski (1997) dietas com níveis de enxofre que variam de 0,3 a $0,4 \%$ podem causar intoxicação por enxofre.

Para Loneragan et al. (1998) o método semi-quantitativo de dosagem de gás sulfídrico ruminal desenvolvido por Gould et al. (1997) utilizando tubos colorimétricos foi útil para investigação da etiologia do surto de PEM em bezerros de corte recém desmamados e confinados, principalmente por disponibilizar rapidamente os valores do sulfeto de hidrogênio ruminal. Um detalhe importante desta técnica é a necessidade de se realizar a dosagem em animais clinicamente normais e que estejam recebendo a mesma dieta, pois, os doentes por estarem em anorexia podem apresentar baixos valores.

A técnica utilizada para a determinação da concentração de gás sulfídrico ruminal foi adaptada de Gould et al. (1997) com as modificações descritas por Cunha et al. (2009). Inicialmente foi realizada a tricotomia da fossa paralombar esquerda e anti-sepsia com iodopovidona (PVPI). A punção ruminal foi realizada no ponto médio da porção mais dorsal da fossa paralombar esquerda utilizando-se agulha do cateter intravenoso $14 \mathrm{G}$ sem a cânula externa de teflon. Em seguida, foi encaixado ao conector da agulha um equipo intravenoso com $15 \mathrm{~cm}$ de comprimento, cortando e desprezando-se a extremidade com o gotejador. A ponta cortada do equipo adaptado foi acoplada ao tubo colorimétrico de dosagem de gás sulfídrico, que já estava previamente inserido na bomba manual de vácuo (modelo AP-20S, Sensidyne ${ }^{\circledR}$, Florida, EUA). As mensurações foram realizadas de acordo com o manual do fabricante da bomba de vácuo, padronizando em $100 \mathrm{~mL}$ de gás para valores entre 25 a 1.000 ppm (modelo $120 \mathrm{SF}$, Sensidyne ${ }^{\circledR}$, Florida, EUA) e de 1.000 a 40.000 ppm (modelo $120 \mathrm{SH}$, Sensidyne ${ }^{\circledR}$, Florida, EUA) de sulfeto de hidrogênio com tempo de amostragem de 1,5 minutos. Para Loneragan et al. (1998) valores de sulfeto de hidrogênio ruminal inferiores a 500 ppm foram considerados como normais pelo método descrito por Gould et al. (1997).

Loneragan et al. (1998) relataram surto de PEM em bezerros de corte recém desmamados e confinados ocasionado pela ingestão excessiva de sulfato (9.000 ppm enxofre 
na matéria seca). Na análise do LCR de um animal com sintomatologia nervosa detectou-se aumento da concentração das proteínas $(149 \mathrm{mg} / \mathrm{dL})$ e leve pleocitose (12 leucócitos/ $\mu \mathrm{L}$ ), sendo que $90 \%$ eram células mononucleares, $6 \%$ linfócitos e $4 \%$ neutrófilos.

O exame macroscópico sob aplicação da luz ultra-violeta no comprimento de $365 \mathrm{~nm}$ (lâmpada de Wood) é indicado como método auxiliar para diagnóstico da PEM causada tanto por deficiência da tiamina como por ingestão excessiva de enxofre (Little 1978, Edwin \& Jackman 1981, Shibahara et al. 1999, Gould 2000), mas existem várias teorias que tentam detectar a substância autofluorescente no cérebro. Para Little (1978) a fluorescência é produzida pela autofluorescência da lipofuscina-ceroide presente nos macrófagos. Falhas no teste podem ocorrer em animais no início da doença porque os macrófagos ainda não engolfaram as células necróticas e incorporaram nos lisossomos ou em fases intermediárias, em que a quantidade de lipofuscinaceroide presente nos macrófagos não é suficiente para emitir fluorescência. Entretanto, Edwin \& Jackman (1981) descrevem que a fluorescência estaria correlacionada com elementos estruturais do cérebro como material semelhante a colágeno de alto peso molecular.

As lesões da PEM por enxofre são caracterizadas por necrose cerebrocortical neuronal. Inicialmente os neurônios estão retraídos e com citoplasma homogêneo e eosinofílico. O núcleo está picnótico, desbotado ou ausente. Além disso, a neurópila perde o modelo dendritico normal e tornase homogênea e algumas vezes hipereosinofilica. Em estágios mais avançados, o tecido cortical afetado sofre cavitações, infiltram-se macrófagos e tecidos necróticos são removidos. Apesar das cavitações serem bastante evidentes, neste estágio a autofluorescência não é observada. Este nível de lesão é o mais comumente observado, na forma subaguda da doença envolvendo cegueira e ataxia (Gould 2000).

Além das lesões corticais descritas anteriormente, podem ocorrer alterações de malacia e edema em estruturas profundas do encéfalo, como mesencéfalo, tálamo, núcleos basais e hipocampo (McAllister et al. 1992, Hamlen et al. 1993, Jeffrey et al. 1994, Low et al. 1996, 
Loneragan et al. 1998, Sant'Ana et al. 2009ab). Em bovinos intoxicados naturalmente por enxofre, hemorragias focais no tálamo e mesencéfalo ocorrem secundariamente a degeneração de veias e vênulas (Loneragan et al. 1998) e necrose fibrinóide de pequenas arteríolas (Hamlen et al. 1993, Hill \& Ebbett 1997). Jeffrey et al. (1994) e Low et al. (1996) sugerem que nos casos em que há necrose neuronal cortical associada a lesões em estruturas mais ventrais do encéfalo, o quadro é sugestivo de PEM ocasionada por enxofre, favorecendo a diferenciação da PEM relacionada à deficiência de tiamina.

\subsubsection{Tratamento}

Bovinos afetados com PEM devido toxicose por enxofre e tratados com tiamina podem apresentar resposta eficaz em alguns casos (Harries et al. 1987, Gooneratne et al. 1989). Para Olkoswi et al. (1992) a eficácia da resposta do tratamento com tiamina nos caso de intoxicação por enxofre nos bovinos estaria correlacionada inversamente com o grau de lesão do encéfalo, pois, na maioria dos casos a terapia teve sucesso nos animais que apresentavam sinais neurológicos brandos, indicando que era fase inicial da PEM.

A molécula de tiamina possui características químicas que conferem proteção contra os metabólicos tóxicos do enxofre, como sulfeto e sulfito, os quais são constantemente produzidos no rúmen. A tiamina age limpando os radicais livres, sendo que a deficiência pode aumentar a intensidade da peroxidação lipídica. A capacidade de reagir rapidamente com íons sulfito pode ser considerada como processo de desintoxicação. Este processo ocasiona destruição de um grande número de moléculas de tiamina, ocasionando deficiência secundária. A conformação molecular de tiamina é um anel aberto de tiazole com exposição do grupo - SH que pode servir como conjugado para desintoxicar derivados de sulfitos. Desta forma, a hipótese de que maior demanda por tiamina livre pode ser necessária nos casos de intoxicação por enxofre é plausível (Olkoswi et al. 1992) 
Entretanto, a literatura compilada recomenda como tratamento da PEM independente da causa, exceto pelo BoHV-5, a administração de tiamina e glicocorticóides associado com a imediata substituição da alimentação e da água.

A terapia de suporte recomendada consiste na administração de 10 a $20 \mathrm{mg}$ de tiamina por Kg de peso vivo por via intravenosa, a cada oito horas no primeiro dia, seguindo-se de dose similar, por via intramuscular, por mais três dias. Administra-se também 0,2 mg de dexametasona por $\mathrm{Kg}$ de peso vivo por via intravenosa para redução do edema cerebral (McKenzie et al. 2009). Radostitis et al. (2007) recomenda a administração de 10 a $20 \mathrm{mg}$ de tiamina por $\mathrm{Kg}$ de peso vivo, por via intramuscular, devendo ser repetido de $4 \mathrm{em} 4 \mathrm{~h}$ ou de $6 \mathrm{em} 6 \mathrm{~h}$, durante três dias Em condições de campo, onde há dificuldade para a realização de um desses esquemas terapêuticos, tem sido utilizada a repetição das doses indicadas de 24 em 24 h por três dias consecutivos (Riet-Correa et al. 2007).

Loneragan et al. (1998) administraram dexametasona $(0,2 \mathrm{mg} / \mathrm{Kg}, \mathrm{IV}$, dose única), tiamina (10 mg/Kg, IV, 12/12 h) e cetfiour sódico $(1,1 \mathrm{mq} / \mathrm{Kg}$, IM, 24/24 h) para uma novilha que apresentava sinais de ataxia, depressão, amauose e "head pressing" ocasionada pela ingestão de $0,9 \%$ de enxofre na dieta. Após três dias de tratamento o animal apresentava melhora substancial do apetite e do comportamento.

Loneragan et al. (2005) relataram que uma novilha do grupo experimental que recebia sulfato $(2360 \mathrm{mg} / \mathrm{L})$, via fonte hídrica, apresentou cegueira e ataxia com 17 dias de confinamento. $\mathrm{Na}$ dosagem de gás sulfídrico ruminal realizada três dias antes do aparecimento dos sinais foi detectado valor de 13.448 ppm. Após uma semana de tratamento com $30 \mathrm{mg}$ de dexametasona por via intramuscular e $2 \mathrm{~g}$ de tiamina pela via intravenosa, a novilha retornou para o confinamento apresentando somente dificuldade visual. Ao finalizar o período experimental de 113 dias, a novilha foi sacrificada e foram observadas alterações macroscópicas e histopatológicas compatíveis com PEM. 
O prognóstico do animal está diretamente associado com a administração da terapia suporte logo após o aparecimento dos sinais clínicos (Radostitis et al. 2007, McKenzie et al. 2009).

\subsubsection{Medidas de prevenção e controle}

A determinação da concentração de sulfeto de hidrogênio ruminal fornece evidências de consumo excessivo de enxofre podendo inclusive ser usada para monitorar situações de risco. Após a determinação de altos valores de gás sulfídrico, fontes alternativas de água e alimento devem ser disponibilizadas enquanto se espera os resultados da análise laboratorial da concentração de enxofre nos componentes da dieta e na água (Loneragan et al 1998).

Kung et al. (1998) após avaliarem a capacidade do 9,10-anthraquinone de reduzir a produção excessiva de sulfeto de hidrogênio na fermentação ruminal in vitro, em diferentes tipos de culturas de microrganismos ruminais suplementados com várias formas do enxofre, concluíram que este produto pode ser utilizado pra prevenir a produção excessiva de sulfeto de hidrogênio ruminal.

Como medidas de controle deve-se fornecer adequadamente a suplementação mineral, evitar a privação de água e mudanças bruscas ou excesso de enxofre na alimentação (Riet-Correa et al. 2007). 
CAPÍTULO 
Trabalho a ser enviado para a revista Pesquisa Veterinária Brasileira.

\section{Polioencefalomalacia experimental em bovinos com dieta contendo alto teor de enxofre}

(Experimental polioencephalomalacia in calves fed a diet with high sulphur concentration)

ABSTRACT: Polioencephalomalacia (PEM) in cattle has been caused by excess sulphur intake. The aim of this study was to induce PEM in calves fed a diet high in carbohydrate and low in long fiber with high sulphur concentrations $(0.52 \%$ dry matter). Ten crossbred calves were fed an experimental diet, four without sodium sulfate (G1) and six with (G2). The calves were clinically evaluated (retal temperature, cardiac and respiratory rate and ruminal motricity) and laboratorial (hematology, plasma fibrinogen, total protein, ruminal fluid $\mathrm{pH}$, ruminal hydrogen sulfide concentration, cerebrospinal fluid, gross and histopathological). Retal temperature, cardiac rate, hematology, plasma fibrinogen, total protein, ruminal fluid $\mathrm{pH}$ and cerebrospinal fluid values were within references ranges in both groups. Ruminal hipomotricity and increased in respiratory rate and ruminal hydrogen sulfide concentration occurred in calves consuming the diet with added sodium sulfate. One of the six calves fed the high-sulfate diet developed neurological signs and lesions of PEM. Two calves of the groups 1 and 2 were euthanized. Evidences of microscopic lesions of PEM were observed only in calves of group 2 although clinic signs were not seen. Histologically the maily alterations noted were cortical neuronal necrosis and hemorrhagic lesions in basal nuclei, thalamus, midbrain, pons and medulla oblongata. PEM in calves can result from excess sulphur intake $(0.52 \%$ dry matter) associated with a diet high in carbohydrate and low in long fiber.

INDEX-TERMS: cerebrocortical necrosis, sulphur, cattle, experimental model, ruminal hydrogen sulfide. 
RESUMO: Polioencefalomalacia (PEM) nos bovinos tem sido ocasionada pelo consumo excessivo de enxofre. O presente trabalho teve como objetivo verificar se uma dieta rica em carboidrato de alta fermentação, baixa quantidade de fibra efetiva e alta concentração de enxofre $(0,52 \%$ na matéria seca) pode induzir PEM em bovinos. Foram utilizados dez bezerros mestiços leiteiros, sendo que quatro bovinos ingeriram ração sem sulfato de sódio (G1), enquanto seis consumiram ração com sulfato de sódio (grupo 2). Exames clínicos (temperatura retal, frequência cardíaca e respiratória e motricidade ruminal) e laboratoriais (hemograma, fibrinogênio e proteína plasmática, $\mathrm{pH}$ fluido ruminal, concentração do sulfeto de hidrogênio ruminal, líquido cerebrospinal e histopatológico) foram realizados. A temperatura retal, a frequência cardíaca, o hemograma, o fibrinogênio e proteína plasmática, o $\mathrm{pH}$ do fluido ruminal e os valores do líquido cerebrospinal estava dentro dos valores de referência. Taquipnéia, hipomotricidade ruminal e elevados valores de sulfeto de hidrogênio ruminal foram observados nos bezerros do grupo G2. Um bezerro do grupo G2 apresentou sinais neurológicos e lesões histopatológicas de PEM. Dois animais de cada grupo foram eutanasiados. Evidências de lesões microscópicas foram observadas somente nos bezerros G2, apesar dos dois animais não apresentarem sinais clínicos. Histologicamente as principais alterações observadas foram necrose neuronal cortical e lesões hemorrágicas nos núcleos basais, tálamo, mesencéfalo, ponte e bulbo. A PEM em bezerros foi ocasionada pelo consumo excessivo de enxofre (0,52\% matéria seca) associado com dieta rica em carboidrato de alta fermentação e baixa quantidade de fibra efetiva.

TERMOS-INDEXAÇÃO: necrose cerebrocortical, enxofre, bovinos, modelo experimental, sulfeto hidrogênio ruminal. 


\section{INTRODUÇÃO}

A polioencefalomalacia (PEM) é uma doença cerebrocortical degenerativa dos ruminantes sendo o termo utilizado para indicar lesão de necrose laminar do córtex cerebral possuindo vários fatores associados a sua ocorrência (Gould 1998, 2000, Cebra \& Cebra 2004, Burgess 2008, Santana et al 2009ab).

$\mathrm{Na}$ literatura internacional a principal causa de PEM relatada tem sido intoxicação por enxofre (Raisbeck 1982, Gunn et al 1987, Gooneratne et al 1989, Sager et al 1990, Hamlen et al 1993, Jeffrey et al 1994, McAllister et al 1997, Loneragan et al. 1998, Gould 1998, Gould 2000, Niles et al 2000, Gould et al 2001, Loneragan et al. 2001, Niles et al 2002, Haydock 2003, Loneragan et al. 2005, Kul et al. 2006, Dewhurst et al 2007, McKenzie et al. 2009). Outras etiologias descritas foram deficiência da tiamina (Jensen et al 1956, Edwin \& Jackman 1973), intoxicação por sal associada à privação de água (Trueman \& Clague 1978, Osweiler et al 1995), intoxicação por chumbo (Christian \& Tryphonas 1971), ingestão de melaço (Mella et al. 1976) e ingestão de plantas ricas em tiaminases (Pritchard \& Eggleston 1978) e a infecção com o herpesvírus bovino 5 (BoHV-5) (Perez et al. 2003).

No Brasil, existem relatos de ocorrência de surtos de PEM em bovinos ocasionados por intoxicação por sal associada à privação de água (Lemos et al. 1997, Nakazato et al. 2000), intoxicação por chumbo (Lemos et al. 2004, Traverso et al. 2004), forma aguda da intoxicação por Phalaris spp. (Souza \& Irigoven 1999) e infecção pelo BoHV-5 (Salvador et al. 1998, Sanches et al 2000, Claus et al 2002, Colodel et al 2002, Elias et al 2004, Riet-Correa et al. 2006, Barros et al., 2006, Mendes et al 2007, Rissi et al 2006, 2007, 2008, Lunardi et al 2009). O diagnóstico de PEM associado com distúrbio no metabolismo da tiamina (Santos et al 1983, Gonçalves et al. 2001, Mendes et al 2007), intoxicação por enxofre (Traverso et al 2001, Sant Ana et al. 2009b) e alterações bruscas na dieta (Moro et al. 1994) foram estabelecidos correlacionando dados 
epidemiológicos, sinais neurológicos, achados histopatológicos e/ou resposta favorável à terapia com tiamina (diagnostico terapêutico), sendo as etiologias determinadas a partir de suposições, não sendo confirmadas laboratorialmente.

A necessidade da melhor compreensão da etiopatogenia da PEM no Brasil tem estimulado o estabelecimento de modelos experimentais em ruminantes. Em um estudo experimental foi demonstrado que bovinos que tinham sido inoculados anteriormente com BoHV-5 desenvolviam meningoencefalite após a indução de PEM mediante a administração de amprólio ou sulfato de sódio (David et al 2007). Cunha et al (2008) induziram PEM em dois bovinos Nelore fornecendo diariamente por via nasoesofágica enxofre a 1\% da matéria seca e Santana et al (2009c) intoxicaram cinco ovinos administrando por via oral amprólio nas doses diárias de 500 e $1.000 \mathrm{mg} / \mathrm{Kg}$ de peso vivo.

O objetivo desse trabalho foi avaliar se o consumo excessivo de enxofre associado com dieta rica em carboidrato de alta fermentação e baixa quantidade de fibra efetiva pode induzir PEM em bovinos mestiços leiteiros.

\section{MATERIAL E MÉTODOS}

Foram utilizados 10 bezerros mestiçosleiteiro, machos, de oito meses de idade, com peso entre $100-120 \mathrm{~kg}$ e mantidos durante todo o período experimental em baias individuais. Os animais foram distribuídos aleatoriamente em dois grupos, sendo que quatro bovinos não tiveram adição de sulfato de sódio na ração (G1), enquanto que para seis animais foi acrescentado o sulfato de sódio (G2). O grupo G1 foi constituído pelos bovinos 3, 5, 10 e 11, enquanto o grupo G2 pelos bezerros $1,4,6,7,8$ e 9. Na ração do grupo G2 foi adicionado diariamente como fonte de enxofre, o sulfato de sódio, totalizando consumo de $0,52 \%$ de enxofre na matéria seca. 
O protocolo de intoxicação foi adaptado de Sager et al. (1990) com algumas modificações. O período experimental foi dividido em três fases. A fase 1 constituiu a adaptação dos bovinos com suplementação exclusiva de feno por um período de 14 dias, enquanto a fase 2 compreendeu um período de sete dias de transição do feno para ração, retirando-se $1 / 2 \mathrm{Kg}$ do feno/dia/bezerro e adicionando-se $1 / 2 \mathrm{~kg}$ da ração/dia/bezerro. Na ultima fase (fase 3), os animais receberam durante 14 dias exclusivamente ração. A ingestão do feno Coast-cross (Cynodon dactylon) e o consumo da ração foram de $2,5 \%$ do peso vivo.

A ração fornecida era constituída por casca de aveia (30\%), farelo de soja $(18,5 \%)$, amido (17\%), dextrose $(17 \%)$, óleo milho (4\%), uréia $(3 \%)$, bicarbonato de sódio $(2 \%)$, fosfato de cálcio $(2,5 \%)$, sulfato de sódio $(0,8 \%)$, cloreto de potássio $(0,5 \%)$, óxido de magnésio $(0,2 \%)$ e água (4,5\%). Ainda foram incorporados na ração $2.000 \mathrm{UI} / \mathrm{kg}$ vitamina A, $100 \mathrm{UI} / \mathrm{kg}$ vitamina D, 20 $\mathrm{UI} / \mathrm{kg}$ vitamina E, $80 \mathrm{mg} / \mathrm{kg}$ ferro, $40 \mathrm{mg} / \mathrm{kg}$ manganês, $20 \mathrm{mg} / \mathrm{kg}$ zinco, $1 \mathrm{mg} / \mathrm{kg}$ cobalto, $1 \mathrm{mg} / \mathrm{kg}$ iodo e $4 \mathrm{mg} / \mathrm{kg}$ cobre.

A análise bromatológica do feno de Coast-cross (Cynodon dactylon) (95,33\% matéria seca; 10,28\% proteína bruta; $6,35 \%$ extrato etéreo; $4,54 \%$ minerais; $33,98 \%$ fibra bruta; $44,85 \%$ extrato não nitrogenado; $63,5 \%$ nutrientes digestíveis totais; $76,89 \%$ fibra detergente neutra; $40,7 \%$ fibra detergente ácida) e da ração ( $90,45 \%$ matéria seca; $21,19 \%$ proteína bruta; 4,31\% extrato etéreo; 10,7\% minerais; $3,92 \%$ fibra bruta; $59,88 \%$ extrato não nitrogenado; $87,27 \%$ nutrientes digestíveis totais; $29,34 \%$ fibra detergente neutra; $13,25 \%$ fibra detergente ácida) foram realizadas no Laboratório de Bromatologia do Departamento de Melhoramento e Nutrição Animal da Faculdade de Medicina Veterinária e Zootecnia da Universidade Estadual Paulista "Júlio de Mesquita Filho" (FMVZ/UNESP/Botucatu).

As análises de elementos minerais do feno de Coast-cross (Cynodon dactylon) (14 g/Kg de nitrogênio, 1,1 g/Kg de fósforo, $15 \mathrm{~g} / \mathrm{Kg}$ de potássio, $2 \mathrm{~g} / \mathrm{Kg}$ cálcio, $1,0 \mathrm{~g} / \mathrm{Kg}$ de magnésio, 3,5 g/Kg de enxofre, $14 \mathrm{mg} / \mathrm{Kg}$ de boro, $9 \mathrm{mg} / \mathrm{Kg}$ de cobre, $190 \mathrm{mg} / \mathrm{Kg}$ de ferro, $156 \mathrm{mg} / \mathrm{Kg}$ de manganês e 
$16 \mathrm{mg} / \mathrm{Kg}$ de zinco) e da ração (3,32 g/Kg de nitrogênio, $5 \mathrm{~g} / \mathrm{Kg}$ de fósforo, 6,5 $\mathrm{g} / \mathrm{Kg}$ de cálcio, 2,2 $\mathrm{g} / \mathrm{Kg}$ de magnésio, $940 \mathrm{mg} / \mathrm{Kg}$ de enxofre, 227,5 mg/Kg de ferro, $80 \mathrm{mg} / \mathrm{Kg}$ de manganês, 0,80 $\mathrm{mg} / \mathrm{Kg}$ de selênio, $20 \mathrm{mg} / \mathrm{Kg}$ de cobre, 77,5 mg/Kg de zinco, 5,5 g/Kg de sódio, $35 \mathrm{mg} / \mathrm{Kg}$ de boro e $2,5 \mathrm{mg} / \mathrm{Kg}$ de molibdênio) foram realizadas, respectivamente, nos Laboratórios de Nutrição Mineral de Plantas do Departamento de Recursos Naturais e Ciência do Solo da Faculdade de Ciências Agronômicas da UNESP/Botucatu e no Instituto Campineiro de Análise de Solo e Adubo Ltda. A dosagem de enxofre da água $(11 \mathrm{mg} / \mathrm{L})$ do poço semi-artesiano foi conduzida no Laboratório de Fertilizantes e Corretivos da Faculdade de Ciências Agronômicas da UNESP/Botucatu.

Os animais foram retirados das baias, localizadas ao lado do local de exame e imediatamente colocados em tronco de contenção para a realização do exame físico. Em seguida, foram obtidas amostras de sangue para realização do hemograma, fibrinogênio e proteína plasmáticos, de gás ruminal para determinar às concentrações do sulfeto de hidrogênio ruminal $\left(\mathrm{H}_{2} \mathrm{~S}\right.$ ou gás sulfídrico) e por último colhido o fluido ruminal para realizar aferição do $\mathrm{pH}$ ruminal. Diariamente os animais foram monitorados visando detecção de sinais clínicos neurológicos, enquanto o exame físico, as dosagens de gás sulfídrico ruminal e as colheitas das amostras de sangue e líquido ruminal foram realizadas com intervalos sete ou 14 dias (quadro 1) para evitar estresse de manejo e interferência no consumo da ração. No final da fase 3 foram colhidas amostras do líquido cefalorraquidiano (LCR) dos animais 4, 6, 7, 8 e 9.

As amostras de sangue total foram colhidas por venopunção da jugular em tubos contendo anticoagulante (EDTA) e submetidas à contagem de células em câmara hematimétrica de Neubauer, à determinação do volume globular pelo método do microhematócrito e à dosagem de hemoglobina pelo método da cianometahemoglobina, calculando-se posteriormente os índices hematimétricos (volume globular médio e concentração de hemoglobina globular média) (Coles, 1984). A contagem diferencial de leucócitos foi realizada em 100 células em esfregaços sanguíneos corados 
pelo panótico rápido. Para mensuração do fibrinogênio utilizou-se a técnica de precipitação no tubo de microhematócrito a $56^{\circ} \mathrm{C}$, enquanto a proteína foi determinada diretamente pela refratometria (Coles, 1984).

A técnica da dosagem de sulfeto de hidrogênio ruminal utilizada foi adaptada de Gould et al. (1997) com as modificações descritas a seguir. Inicialmente foi realizada a tricotomia da fossa paralombar esquerda e anti-sepsia com iodopovidona (PVPI), sendo que a punção ruminal foi realizada no ponto médio da porção mais dorsal da fossa paralombar esquerda utilizando-se agulha do cateter intravenoso $14 \mathrm{G}$ sem a cânula externa de teflon. Em seguida, foi encaixado ao conector da agulha um equipo intravenoso com $15 \mathrm{~cm}$ de comprimento, cortando e desprezando-se a extremidade com o gotejador. A ponta cortada do equipo adaptado foi acoplada ao tubo colorimétrico de dosagem de gás sulfídrico, que já estava previamente inserido na bomba manual de vácuo (modelo AP-20S, Sensidyne ${ }^{\circledR}$, Florida, EUA). As mensurações foram realizadas de acordo com o manual do fabricante da bomba de vácuo, padronizando em $100 \mathrm{~mL}$ de gás para valores entre 25 a 1.000 ppm (modelo $120 \mathrm{SF}$, Sensidyne ${ }^{\circledR}$, Florida, EUA) e de 1.000 a 40.000 ppm (modelo 120 SH, Sensidyne ${ }^{\circledR}$, Florida, EUA) de sulfeto de hidrogênio com tempo de amostragem de 1,5 minutos. Nos momentos em que não ocorreu mudança na coloração do tubo, repetiu-se a dosagem e não detectando alteração foi estabelecido que o valor aferido estivesse abaixo do limite inferior de detecção do tubo (<25 ppm de $\mathrm{H}_{2} \mathrm{~S}$ ruminal).

As amostras do conteúdo ruminal foram obtidas por meio de uma bomba de sucção a vácuo, acoplada a um recipiente de vidro e a sonda oroesofágica tipo Schambye e Sorensen (Dirksen et al. 1993). Para avaliação do $\mathrm{pH}$ ruminal (Phtek ${ }^{\circledR}$, modelo $\left.\mathrm{pH} 100\right)$ os primeiros $200 \mathrm{~mL}$ foram desprezados para evitar contaminação pela saliva, sendo colhidos aproximadamente $100 \mathrm{~mL}$ de cada animal.

As coletas de LCR foram realizadas segundo protocolo proposto por Mayhew (1989). Após sedação com 0,20 mg/kg/IV de cloridrato de xilazina (Vibaxil 2\%, Virbac Saúde Animal, 
Jurubatuba, SP, Brasil), tricotomia e anti-sepsia com iodopovidona (PVPI) foi realizada punção na cisterna atlanto-occipital com agulha spinal 20G x 3 1⁄2”( BD, CAT.408373, São Paulo, SP, Brasil).

As amostras de LCR foram coletadas em três tubos estéreis sem EDTA. Para análise do LCR foi utilizada uma fração da amostra do terceiro tubo. O número de leucócitos e hemácias por microlitro do LCR foi mensurado com o uso da câmara de Fuchs-Rosenthal. A contagem diferencial de leucócitos foi feita em lâminas preparadas por citocentrifugação (Citocentrífuga Citológica Microprocessada, 200D, CIENTEC, Piracicaba, SP, Brasil) e coradas com método Panótico (Instant Prov, NEWPRO, Pinhais, PR, Brasil). As proteínas (Sensiprot, Labtest Diagnóstica, Lagoa Santa, MG) e a glicose (Glicose Pap, Labtest Diagnóstica, Lagoa Santa, MG) foram dosadas com kits comerciais, empregando o método colorimétrico, cujas leituras das reações foram feitas em espectrofotômetro (Espectrofotômetro Digital B 44242 -Micronal- São Paulo - SP - Brasil).

O bovino que morreu naturalmente (bezerro 1) e os animais submetidos à eutanásia (bezerros 4 , 5, 7 e 10) foram necropsiados. A eutanásia foi realizada utilizando cloridrato de xilazina $(0,10$ $\mathrm{mg} / \mathrm{Kg}$ por via intravenosa), tiopental sódico ( $8 \mathrm{mg} / \mathrm{Kg}$ por via intravenosa) e por último cloreto de potássio.

Amostras de tecido hepático e renal dos animais 1, 4, 7 e 10 foram coletadas para dosagem de chumbo por espectrofotometria por absorção atômica no Centro de Assistência Toxicológica (CEATOX) do Instituto de Biociências da UNESP/Botucatu.

Uma porção do córtex frontal do bezerro 1 foi colhida para realizar a técnica da PCR para detecção do DNA do herpesvírus bovino 5. O processo de extração de DNA foi realizado a partir de 20 mg da amostra de encéfalo utilizando kit de extração QIAamp ${ }^{\circledR}$ DNA Mini Kit (QIAGEN ${ }^{\circledR}$ cat $n^{\circ}$. 51304). A técnica da PCR foi realizada segundo Claus et al. (2005) com algumas modificações. Os "primers" utilizados foram B5 (senso) específico para BoHV-5 (5' - CGG ACG AGA CGC CCT TGG-3' NT 322-339) e primer anti-senso denominado Bcon (5'- AGT GCA CGT ACA GCG 
GCT CG-3' NT 519-538), que amplificaram fragmento com 159 pb do gene da glicoproteína C do BoHV-5. Como controle positivo utilizou-se amostra AA PAR do BoHV-5, isolada do cérebro de um bovino apresentando sinais de encefalite cedida pelo Laboratório de Virologia Animal do Centro de Ciências Agrárias da Universidade Estadual de Londrina. Realizou-se a PCR com a enzima GoTaq ${ }^{\circledR}$ Green Master Mix (Promega, Madison, WI, EUA). A reação foi padronizada para um volume final de $50 \mu \mathrm{l}$ e possuía $0,4 \mu \mathrm{M}$ de cada oligonucleotídeo iniciador (senso e anti-senso), $5 \mu \mathrm{l}$ de DNA, $25 \mu \mathrm{l} \mathrm{GoTaq}^{\circledR}$ Green Master Mix, 8\% DMSO (Sigma ${ }^{\circledR}$ ) e água “nuclease-free” q.s.p. O processo de amplificação foi realizado em termociclador (Mastercycler ${ }^{\circledR}$ ep Eppendorf) de acordo com as seguintes condições de tempo e temperatura: 1 ciclo de 2 min a $95^{\circ} \mathrm{C}$ seguido por 40 ciclos de 40 segundos a $94^{\circ} \mathrm{C}$ (denaturação), 1 min com temperatura de hibridização de $57,8^{\circ} \mathrm{C}, 1$ min a $72^{\circ} \mathrm{C}$ (extensão) e um ciclo de extensão final de 5 min a $72^{\circ} \mathrm{C}$. Os produtos amplificados foram analisados por eletroforese em gel de agarose a 1,5\%, corado com GelRed ${ }^{\mathrm{TM}}$ (Biotium, Halward, CA, EUA) e visualizado sob luz ultra-violeta. Os géis foram documentados no ImageQuant ${ }^{(G E}$ Healthcare).

Os fragmentos encefálicos (porção occipital do telencéfalo, tálamo, vermix do cerebelo e a porção final do tronco encefálico após o óbex) do bezerro 1 foram congelados e encaminhados para exame de imunofluorescência direta para diagnóstico diferencial de raiva no Departamento de Higiene e Saúde Pública da FMVZ/UNESP/Botucatu.

Para o exame histopatológico foram colhidas as seguintes porções do sistema nervoso central (SNC): bulbo olfatório, córtex frontal (anterior) na altura do joelho do corpo caloso, córtex occipital (posterior), córtex parietal (dorso-lateral), núcleos basais, tálamo, mesencéfalo na altura dos colículos rostrais, ponte com pedúnculos cerebelares, bulbo na altura do óbex e cerebelo. Adicionalmente foram examinados em monobloco o gânglio de Gasser (trigêmeo), rete mirabile e hipófise (GRH). As amostras foram fixadas em formol tamponado a 10\% para a realização do exame histopatológico. 
$\mathrm{Na}$ análise histopatológica, a intensidade das lesões foi estabelecida considerando lesão discreta (1) quando menos de $25 \%$ do tecido estava afetado, moderado (2) referente a alterações de 25 a $50 \%$ e acentuadas (3) indicando comprometimento acima de $50 \%$ do tecido avaliado. Os seguintes aspectos foram computados para a obtenção da intensidade das lesões: hemorragia, congestão, edema do neurópilo, infiltrado inflamatório, meningite, gliose focal, gliose difusa, neurônios vermelhos (neurônios com o citoplasma encolhido e eosinofílico e núcleo picnótico), neuronofagia, malacia (necrose do componente neuroectodérmico com manutenção das estruturas mesenquimais e infiltrado de macrófagos tumefeitos e com citoplasma espumoso [células Gitter]), e lesão residual (estruturas vasculares e células Gitter remanescentes, formando uma estrutura cavitária semelhante a um cisto). Cada um dos parâmetros avaliados foi relacionado à seção anatômica examinada, com o objetivo de determinar a localização das lesões produzidas pela doença no SNC. Adicionalmente, foram avaliados qualitativamente o tipo de infiltrado inflamatório e a presença de corpúsculos de inclusão intranucleares característicos de herpesvírus (Rissi et al. 2006, Sant'Ana et al. 2009a).

Para a avaliação das diferenças entre as médias dos resultados obtidos, foram utilizados os testes de análise de variância (ANOVA) para comparação entre as fases do período experimental por grupo e de Mann-Whitney para verificar diferenças entre os grupos G1 e G2. Para todos os resultados, foram consideradas significantes as análises que apresentaram $p \leq 0,05$. Para as avaliações estatísticas, foi utilizado o software estatístico GraphPad InStat versão 3.0 para Windows (GraphPad Software). Para realização da análise estatística foi considerado o valor de 24 ppm nas aferições referentes aos valores inferiores a 25 ppm do sulfeto de hidrogênio ruminal.

Todos os procedimentos realizados encontram-se de acordo com as normas e princípios éticos de experimentação animal, estabelecidos pela Câmara de Ética em Experimentação Animal da FMVZ/UNESP/Botucatu, sendo o experimento aprovado pela mesma (Protocolo nº117/2006CEEA). 


\section{RESULTADOS E DISCUSSÃO}

O período inicial de 15 dias (fase 1) foi importante porque proporcionou adaptação dos animais nas baias, facilitou manejo dos mesmos no tronco para a realização dos exames físicos e colheita das amostras para a execução dos exames complementares propostos. Na fase 2, a mudança no intervalo de sete dias, de forma gradativa, da dieta contendo feno para alimentação exclusivamente com ração, não ocasionou distúrbios metabólicos como acidose ruminal. No final da fase de transição a ingestão de ração foi de $2,5 \%$ do peso vivo, consumo que se manteve em todos os animais durante os 14 dias da fase 3.

A composição e a proporção dos ingredientes da ração do presente estudo, bem como os resultados da análise bromatológica e mineral foram muito similares à ração experimental utilizada por Sager et al (1990) no protocolo de indução por PEM por ingestão excessiva de enxofre.

Para cálculo do consumo de enxofre pelos bovinos na fase 1, verificou-se que a ingestão do feno foi de $2,5 \%$ do peso vivo representando a ingestão de $0,35 \%$ de enxofre na matéria seca. Para o cálculo da ingestão de enxofre na água foi estimado que um bovino de $120 \mathrm{Kg}$ mantido em temperatura ambiente de $28^{\circ} \mathrm{C}$ deve ingerir aproximadamente 20 litros de água por dia (Gould 2000), totalizando o consumo de $220 \mathrm{mg}$ de enxofre por dia $(0,022 \%$ de enxofre). A ingestão de enxofre na água e feno na fase 1 totalizou o consumo de $0,37 \%$ na matéria seca, valor este acima do nível recomendado $(0,15 \%)$ por Klasing et al. (2005). Este alto consumo de enxofre na matéria seca ocorreu porque o valor determinado no feno estava o dobro do descrito como normal por Valadares Filho (2006). A explicação para incremento do enxofre no feno pode ser justificada pela intensa adubação com sulfato de amônio realizada pela empresa que comercializou o volumoso objetivando aumentar o seu valor nutritivo. O sulfato de amônio quando utilizado como fertilizante proporcionou aumento na concentração de enxofre na forragem (Arthington et al. 2002) e melhorou 
a digestibilidade da fibra em detergente ácido e da fibra em detergente neutro das forragens cultivadas nestes solos, quando fornecida aos ruminantes (Ahmad et al. 1995).

Na fase 3, para o grupo G1, o cálculo do consumo de enxofre foi baseado na ingestão de $2,5 \%$ do peso vivo da matéria seca da ração $(0,09 \%$ de enxofre na matéria seca) somado ao da água $(0,022 \%$ de enxofre por dia), totalizando, aproximadamente, $0,11 \%$ de enxofre na matéria seca. Para o grupo G2, acrescentou-se na ração como fonte de enxofre, o sulfato de sódio, que somado à ingestão do enxofre na água totalizou $0,52 \%$ de enxofre na matéria seca. $\mathrm{O}$ estabelecimento do nível tóxico na dieta fornecida para os bovinos do grupo G2 foi baseado nas recomendações do Klasing et al. (2005), que preconizaram o valor de tolerância máxima de enxofre de $0,30 \%$ para dietas compostas com mais de $85 \%$ de concentrado.

$\mathrm{Na}$ avaliação da temperatura retal foram verificadas diferenças significativas $(p<0,05)$ ao comparar no grupo G1 a Fase 3 com as demais, no grupo G2 o primeiro dia da Fase 1 com os outros momentos avaliados e ao comparar os grupos G1 e G2. Com relação a frequência cardíaca e respiratória não foram observadas diferenças significativas entre as fases do período experimental e entre os grupos G1e G2. Os valores médios e desvios-padrão da temperatura retal e frequência cardíaca (quadro 2) permaneceram dentro da faixa de normalidade para a espécie bovina (Radostitis et al. 2007). Entretanto, episódios de taquipnéia foram observados em alguns animais dos dois grupos na fase de adaptação e na fase 3 somente no grupo G2. Gould et al. (1997) ao induzirem PEM com protocolo semelhante ao do presente estudo e também ao descrito por Sager et al. (1990), observaram episódios transitórios de taquipnéia nos bezerros ao ingerirem ração com excesso de enxofre. Os resultados das induções experimentais e as descrições de surtos de PEM por enxofre indicaram que antes dos animais apresentarem sinais neurológicos, a temperatura retal e as frequências cardíaca e respiratória podem estar alteradas (Gunn et al. 1987, Mckenzie et al. 2009) ou não (Loneragan et al. 1998, Haydock 2003). 
Com relação à motricidade ruminal (quadro 2), observou-se no grupo G1 e G2 diferença significativa $(p<0,05)$ da Fase 1 com as Fases 2 e 3, mas não se notou diferença ao comparar os grupos G1 e G2. Nos dois grupos experimentais observou-se valores normais (Dirksen et al. 1993) somente na primeira fase. A hipomotricidade ruminal observadas nas fases 2 e 3 , em ambos os grupos, não foi relatada por Gould et al. (1997), mas estes autores observaram em alguns animais timpanismo gasoso. A hipomotricidade ruminal constatada na fase 2 ocorreu devido à baixa quantidade de fibra oferecida, enquanto que na fase 3 pelo fornecimento de dieta contendo exclusivamente ração. A motricidade ruminal é estimulada pela presença de fibra efetiva, sendo que o fornecimento de concentrado em alta proporção, como estabelecido nas fases 2 e 3, ocasionou baixa motricidade ruminal (Dirksen et al. 1993).

No sexto dia da fase 2 identificou-se um animal (bezerro 1) do grupo G2 com apatia, ataxia, tremor de cabeça e nistagmo vertical com quadro agudo, levando cerca de 10 horas desde o inicio dos sinais até a morte. Observações de sinais neurológicos semelhantes foram relatados por Gould (2000), Cebra \& Cebra (2004), Burgess (2008) e Sant'Ana et al. (2009ab).

Sager et al. (1990) observaram sinais neurológicos em apenas cinco de 14 bovinos alimentados com dieta semelhante ao da presente pesquisa, mas com teor de enxofre inferior $(0,26 \%)$. Os sinais neurológicos nos animais foram identificados sete dias após inicio do fornecimento da ração e caracterizados, inicialmente, por apatia, com evolução para ataxia, amaurose, pressão da cabeça contra objetos e andar compulsivo. Gould et al. (1991) forneceram dieta semelhante ao da presente pesquisa e observaram sinais neurológicos similares aos descritos por Sager et al (1990), mas em cinco de nove bovinos após três dias da introdução da ração com 0,36\% de enxofre na matéria seca. Em outro estudo desenvolvido por Gould et al. (1997) com dieta semelhante a anterior, os autores identificaram amaurose e ataxia em três bovinos de um lote de quatro animais após dois dias do fornecimento da dieta contendo $0,41 \%$ de enxofre na matéria seca. $\mathrm{Na}$ presente pesquisa ao fornecer ração com $0,52 \%$ de enxofre acreditava-se que o número de 
animais doentes seria maior quando comparado com os resultados obtidos por Sager et al. (1990), Gould et al. (1991) e Gould et al. (1997), que suplementaram os bovinos com teores inferiores de enxofre e obtiveram maiores taxas de morbidade. Entretanto, os autores citados anteriormente não observaram quadro clínico com evolução aguda como identificado no bezerro 1. Provavelmente estas diferenças estejam associadas ao tipo de grupo genético empregado, pois, no protocolo experimental americano foram utilizados animais Bos taurus, enquanto no presente estudo foram avaliados bovinos mestiços. Pesquisas comparativas entre Bos taurus e Bos indicus sugerem que há diferenças entre os dois grupos quanto à ingestão alimentar e eficiência de utilização de rações com alta ou baixa densidade de energia (Putrino et al. 2007).

$\mathrm{Na}$ avaliação do eritrograma (quadro 3), leucograma (quadro 4) e fibrinogênio plasmático (quadro 5) não foram verificadas diferenças significativas $(\mathrm{p}<0,05)$ entre as fases do período experimental e entre os grupos G1 e G2. Com relação a proteína plasmática (quadro 5) notou-se diferença significativa no grupo G1 entre o $14^{\circ}$ dia da Fase 1 e $7^{\circ}$ dia da Fase 2 com os demais momentos, enquanto no grupo G2 não foram observadas diferenças entre os momentos e ao comparar os grupos G1 e G2 observou-se diferença significativa $(p<0,05)$ no $1^{\circ}$ e $14^{\circ}$ dias da Fase 1 e $14^{\circ}$ dia da Fase 3 . Os resultados dos eritrogramas e leucogramas, assim como do fibrinogênio e da proteína plasmática (quadro 5) estavam dentro dos valores considerados normais por Radostitis et al. (2007). Loneragan et al. (1998) relataram surto de PEM em bezerros de corte recém desmamados e confinados ocasionado pela ingestão excessiva de enxofre na matéria seca $(0,9 \%)$ e também não observaram alterações nos resultados do leucograma, fibrinogênio e da proteína plasmática. Entretanto, Gunn et al. (1987) relataram surto de PEM ocasionado por flor de enxofre e observaram leucocitose com neutrofilia em alguns animais. Mckenzie et al. (2009) realizaram exames hematológicos em bovinos com PEM devido ingestão de Raphanus raphanistrum que continha elevado teor de enxofre $(0,62 \%)$ e identificaram no eritrograma aumento da hemoglobina, 
do volume globular e do número de hemácias, possivelmente devido a desidratação e leucocitose com hiperfibrinogemia indicando processo inflamatório.

Os valores de gás sulfídrico ruminal (quadro 6) da fase 1 referente à primeira dosagem dos dois grupos experimentais e da segunda aferição ( $7^{\circ}$ dia) do grupo $\mathrm{G} 2$ estavam dentro da faixa de normalidade para a espécie (inferior a 500 ppm) determinada por Burgess (2008). Ainda na fase 1, observou-se que na segunda aferição ( $7^{\circ}$ dia) do $\mathrm{H}_{2} \mathrm{~S}$ ruminal do grupo $\mathrm{G} 1$ e na terceira ( $14^{\mathrm{o}}$ dia) dos dois grupos experimentais, os valores foram superiores aos considerados normais e corroboraram com os resultados de Cunha et al. (2008), que detectaram elevados teores de gás sulfídrico ruminal (5000 ppm) em bovinos alimentados exclusivamente com feno que continha também elevados teores de enxofre na análise mineral foliar. Acredita-se que a ingestão de $0,37 \%$ de enxofre na matéria seca tenha proporcionado os elevados valores de gás sulfídrico ruminal nos animais suplementados exclusivamente com volumoso (fase 1), justificando a importância da determinação deste elemento na dieta (Gould 2000), especialmente no Brasil onde diversos surtos de PEM foram relatados, mas a etiologia não foi esclarecida (Lemos 2005, Barros et al. 2006). Sant’Ana et al. (2009a) ao realizar estudo retrospectivo de 31 casos naturais de PEM em bovinos do Rio Grande do Sul e do Centro-Oeste brasileiro relataram a possibilidade de que alguns dos casos descritos estariam associados à intoxicação por enxofre, embora essa hipótese não tenha sido confirmada laboratorialmente.

Após o inicio do fornecimento da ração (fase 3), os bovinos que receberam sulfato de sódio (G2) apresentaram valores de sulfeto de hidrogênio ruminal acima do considerado normal (Burgess 2008), enquanto no grupo G1 os valores foram inferiores a 280 ppm (figura 1). Com relação aos valores médios do gás sulfídrico foram verificadas diferenças significativas $(p<0,05)$ no G1 no $7^{\circ} \mathrm{e}$ $14^{\circ}$ da fase 1 ao comparar com os demais momentos e no G2 a fase 1 e 2 ao comparar com a fase 3. Além disso, foi observada diferença significativa $(p<0,05)$ entre os grupos G1 e G2 somente na Fase 3 (quadro 6). Em determinados momentos, os valores de $\mathrm{H}_{2} \mathrm{~S}$ ruminal do $\mathrm{G} 2$ foram 100 vezes 
superior aos do G1, indicando que o sulfeto de hidrogênio ruminal é um produto normal do metabolismo da microbiota ruminal, mas quando os bovinos consomem dietas com alto teor de enxofre, ocorre produção excessiva de $\mathrm{H}_{2} \mathrm{~S}$ no rúmen podendo ocasionar a PEM (Gould 2000). Altos valores de gás sulfídrico ruminal em bovinos que ingeriram elevadas quantidades de enxofre também foram descritos por Loneragan et al. (1998), Niles et al. (2002) e Loneragan et al. (2005) e Cunha et al. (2008).

Gould et al. (1997) ao compararem a técnica da dosagem de gás sulfídrico ruminal utilizando tubos colorimétricos com a cromatografia líquida de alta eficiência, não observaram diferenças significativas entre os resultados obtidos, confirmando que a metodologia empregada no presente estudo reflete valores confiáveis da concentração de $\mathrm{H}_{2} \mathrm{~S}$ ruminal, sendo desnecessário o uso de outras técnicas para este propósito.

Variações nos valores do sulfeto de hidrogênio ruminal entre os animais do mesmo grupo e na mesma fase do protocolo experimental também foram relatadas por Niles et al. (2002), que induziram PEM em novilhas fornecendo dieta constituída por $70 \%$ de farelo de glúten de milho (subproduto de grãos) e $30 \%$ de casca de algodão associado com sulfato de sódio em três diferentes concentrações, todas acima do recomendado por Klasing et al. (2005). Isto indica que o metabolismo ruminal do enxofre é rápido e que as concentrações do gás sulfídrico ruminal são dinâmicas e modificam rapidamente em resposta ao consumo de enxofre e a capacidade de absorção pela parede do rúmen (Loneragan et al. 1998).

Gould et al. (1997), Gould (2000) e Burgess (2008) enfatizaram que o odor de "ovo podre" produzido pela eructação do gás sulfídrico ruminal foi associado ao aparecimento da PEM. Coghlin (1944) ao inspecionar a boca dos animais doentes e detectar o odor pútrido de "ovo podre" estabeleceu como causa do surto a ingestão excessiva de enxofre pelos bovinos. Apesar dos elevadores teores de sulfeto de hidrogênio ruminal detectado em todos os animais do G2, 
especialmente na fase 3, em nenhum momento foi identificado odor de ovo em putrefação exalado pelos animais.

Várias investigações têm focado a associação entre a PEM e as altas concentrações do gás sulfídrico ruminal (Gould et al. 1991, Gould et al. 1997, McAllister et al. 1997, Niles et al. 2002, Cunha et al. 2008). A dosagem do sulfeto de hidrogênio ruminal do bezerro 1 no momento em que o mesmo apresentava sinais neurológicos compatíveis com PEM foi de 1250 ppm, valor este 2,5 vezes acima do considerado normal por Burgess (2008). Apesar de Gould et al. (1997) e Loneragan et al (1998) descreverem que em bezerros submetidos a dietas com excesso de enxofre, o aparecimento dos sinais clínicos coincide com o aumento dos valores do sulfeto de hidrogênio ruminal, no presente estudo notou-se isto em apenas um bezerro, enquanto que nos outros animais mesmo apresentando elevadas concentrações de sulfeto de hidrogênio ruminal não foi identificada alteração neurológica no exame clínico.

A determinação do gás sulfídrico ruminal tem sido importante nas investigações dos surtos de PEM porque elevadas concentrações do sulfeto de hidrogênio ruminal indicam participação do enxofre na etiopatogenia desta encefalopatia (Loneragan et al. 1998). A técnica de dosagem de sulfeto de hidrogênio ruminal pelos tubos colorimétricos utilizada neste estudo e por Gould et al. (1997), Niles et al. (2002), Cunha et al. (2008) e Cunha et al (2009ab) demonstrou ser uma ferramenta útil para monitorar situações de risco e auxiliar no diagnóstico definitivo da PEM por enxofre, podendo ser perfeitamente utilizada no campo. A utilização desta técnica associada à análise de enxofre na dieta, pastos, água e suplementos (Gould 2000) estabeleceriam a participação do enxofre nos casos de PEM no Brasil (Lima et al. 2005), bem como auxiliaria no diagnóstico diferencial de outras causas de encefalopatias (Barros et al. 2006).

$\mathrm{Na}$ avaliação do $\mathrm{pH}$ ruminal foram verificadas diferenças significativas $(\mathrm{p}<0,05)$ somente no grupo G1 entre o $14^{\circ}$ dia da Fase 3 com $14^{\circ}$ dia da Fase 1 e $7^{\circ}$ dia da Fase 2, não sendo observada diferença entre os grupos G1 e G2 (quadro 7). Os valores médios do $\mathrm{pH}$ do fluido ruminal dos 
animais dos dois grupos experimentais independente da fase experimental variaram de 6,2 a 7,1 e foram similares aos resultados descritos por Gould et al. (1997). A determinação do pH ruminal de bovinos confinados submetidos a protocolos de indução experimental deve ser realizada para descartar a possibilidade da ocorrência da PEM por alteração no metabolismo da tiamina devido consumo excessivo de ração, que pode diminuir o $\mathrm{pH}$. Na presente pesquisa, mesmo oferecendo na fase 3 uma dieta exclusivamente com ração, o menor valor aferido do $\mathrm{pH}$ ruminal foi de 6,2 para um animal, excluindo a possibilidade da ocorrência de acidose, pois, de acordo com Owens (2007) pH de fluido ruminal abaixo de 5,6 indica acidose crônica, enquanto inferior a 5,2 sugere acidose aguda.

O quadro 8 apresenta os resultados da analise do LCR dos bezerros 4, 6, 7, 8 e 9 do grupo G2. Não foi colhido o LCR do bezerro 1 porque a evolução dos sinais neurológicos foi aguda. As contagens totais e diferenciais das células, assim como as concentrações da glicose e da proteína estão dentro dos valores normais (Stober 1993). Aumento na contagem total das células e na concentração da proteína são as alterações mais marcantes no LCR de animais com PEM (Cebra \& Cebra 2004). Loneragan et al. (1998) ao analisarem o LCR de um animal que havia ingerido dieta rica em enxofre $(0,9 \%$ matéria seca) e com sintomatologia nervosa, detectaram aumento da concentração das proteínas $(149 \mathrm{mg} / \mathrm{dL})$ e discreta pleocitose (12 leucócitos $/ \mu \mathrm{L}$ ), sendo que $90 \%$ eram células mononucleares, $6 \%$ linfócitos e 4\% neutrófilos.

No Brasil, a raiva é a enfermidade neurológica mais frequentemente diagnosticada nos bovinos revelando a importância sócio-econômica e de saúde pública das enfermidades que acometem o SNC. Ao se realizar o diagnóstico diferencial das neuropatias dos bovinos, além da raiva deve-se também incluir todas as causas de PEM (Barros et al. 2006). O exame de imunofluorescência direta para raiva foi negativo para o bezerro 1, assim como não foi identificada a presença do DNA do BoHV-5 realizado por meio da técnica da PCR. Além disso, as concentrações de chumbo nas amostras de tecido hepático e renal (quadro 9) nos bezerros 1, 4, 7 e 10 estavam abaixo dos níveis considerados tóxicos por Lemos \& Riet-Correa (2007). 
As alterações macroscópicas do encéfalo observadas no bezerro 1 indicaram edema do córtex parietal e occipital esquerdo, caracterizado por tumefação com achatamento dos giros cerebrais, sendo que este tipo de lesão foi também descritos tanto nos casos naturais (Hamlen et al. 1993, Loneragan et al. 1998, Haydock 2003, Kul et al. 2006) quanto experimentais (Gould et al. 1991, 1997) de PEM por enxofre. No mesmo animal observou-se que a tumefação do córtex parietal e occipital ocasionaram compressão da porção lateral esquerda do cerebelo (figura 2), mas não foi suficiente para o animal desenvolver opistótono. Acredita-se que neste animal não ocorreu o deslocamento caudal (herniação) do bulbo e do cerebelo no sentido do forame magno conforme citado por Loneragan et al. (1998) e Kul et al. (1996) porque a evolução clínica foi aguda.

No encéfalo dos animais 5 e 10 sacrificados do grupo G1 e dos bezerros 4 e 7 do grupo G2 não foram observadas lesões macroscópicas, mas a ocorrência destas depende da severidade e duração do quadro clínico (Sant'Ana et al. 2009a). Áreas de hemorragia no encéfalo não foram observadas macroscopicamente, mas foi um achado comum, principalmente no telencéfalo e tálamo, nos surtos de PEM ocasionados por excesso de enxofre detectado em diferentes fontes, como a água (Hamlen et al. 1993, Haydock 2003), o feno e água (Loneragan et al. 1998) e a cevada de malte (Kul et al. 2006).

O exame macroscópico sob aplicação pela lâmpada de Wood foi realizado conforme recomendado por Edwin \& Jackman (1981) no encéfalo dos três animais do grupo G2 e não foi evidenciada a autofluorescência. Jeffrey et al. (1994), Gould et al. (1997), McAllister et al. (1997), Loneragan et al. (1998) e Haydock (2003) evidenciaram autofluorescência nos cérebros dos animais que desenvolveram sinais neurológicos e no histopatológico identificaram lesões de malacia no córtex referente as áreas de autofluorescência. Acredita-se que a fluorescência seja devida a metabólitos lipídicos em macrófagos (Little 1978) ou material semelhante a colágeno de alto peso molecular (Edwin \& Jackman 1981). Para Loneragan et al. (1998), o exame de autofluorescência 
indica fortes evidencias para o diagnostico preliminar de PEM, necessitando de exames complementares para definir a causa.

Nos animais 5 e 10 do grupo G1 não foram observadas alterações histopatológicas. Nos animais 1, 4 e 7 do grupo G2, as lesões microscópicas predominaram no córtex frontal, parietal e occipital e incluíram necrose neuronal (neurônios vermelhos), edema de neurópilo e gliose, concordando com Gould (2000). Estas lesões foram acentuadas no bezerro que apresentou sinais neurológicos (figura 3) e com menor intensidade (discretas a moderadas) nos animais 4 e 7 do mesmo grupo que não apresentaram sinais clínicos. Somente no bezerro 1 foram observadas alterações discretas caracterizadas como necrose neuronal e edema nos núcleos basais (figura 4), tálamo (figura 5) e mesencéfalo. Em nenhum animal foi observado infiltrado de macrófagos espumosos (células gitter), manguitos perivasculares e lesões no cerebelo e no complexo gânglio de Gasser, rete mirabile e hipófise. Hemorragias discretas foram observadas no mesencéfalo do animal 4 e na ponte (figura 6) e bulbo (figura 7) do bovino 7. Necrose neuronal cortical associada a lesões no tálamo, ponte e bulbo como as descritas nesta pesquisa foram evidenciados nos casos naturais de PEM ocasionadas por enxofre (Hamlen et al. 1993, Jeffrey et al. 1994, Loneragan et al. 1998) e na indução experimental realizada por Cunha et al. (2008). Para Hamlen et al. (1993), Jeffrey et al. (1994) e Loneragan et al. (1998), lesões hemorrágicas em estruturas mais ventrais do encéfalo como tálamo, ponte e bulbo associadas com necrose cortical podem auxiliar no diagnóstico diferencial da PEM por enxofre daquela ocasionada por deficiência de tiamina.

Em dois surtos de PEM por enxofre, pode-se identificar hemorragias focais no tálamo e mesencéfalo ocorrendo secundariamente a degeneração de veias e vênulas (Loneragan et al. 1998) e necrose fibrinóide de pequenas arteríolas no tálamo e mesencéfalo (Hamlen et al. 1993). No presente trabalho foi somente identificada discreta hemorragia no mesencéfalo de um animal e provavelmente não foi um achado constante porque os animais dos surtos diagnosticados por Loneragan et al. (1998) e Hamlen et al. (1993) ingeriram respectivamente, 0,90\% e 0,70\% de 
enxofre na matéria seca, induzindo um quadro mais grave da doença (Gould 2000), devido o consumo de enxofre muito mais alto do que os bovinos da presente pesquisa. Para Loneragan et al. (1998) a detecção de lesões profundas no encéfalo pode ser uma simples conseqüência da exposição a elevadas quantidades de sulfeto de hidrogênio, determinada pela quantidade de enxofre ingerido e produzido e absorvido.

A identificação de alterações histológicas sugestivas de PEM em animais que não apresentam alterações neurológicas, mas com elevados valores de sulfeto de hidrogênio ruminal, como observada nos animais 4 e 7 do grupo G2, também foram relatadas por Niles et al. (2002).

O protocolo utilizado no presente estudo baseado no fornecimento de uma dieta rica em enxofre foi eficaz na indução de PEM em bovinos. Além disso, para estabelecer o diagnóstico definitivo da PEM por enxofre ficou evidenciado a importância de se utilizar na rotina métodos complementares, tais como, dosagem de gás sulfídrico ruminal, detecção do DNA do BoHV-5 pela PCR, imunofluorescência direta para raiva, determinação da concentração do chumbo nos fragmentos de tecido hepático e renal e do enxofre na dieta associados aos exames histopatológicos.

A necessidade de aumentar a produtividade na bovinocultura no pais tem exigido a utilização de novas estratégias nutricionais, como a utilização de dietas ricas em energia e pobre em fibra associada com o uso de subprodutos da agroindústria. Consequentemente, cria-se condições de risco para ocorrência da PEM por enxofre, estimulando o desenvolvimento de pesquisas com o estabelecimento de modelos experimentais que permitem melhor compreensão da etiopatogenia da PEM no Brasil. 


\section{CONCLUSAO}

A PEM em bezerros mestiços leiteiros foi ocasionada pelo consumo excessivo de enxofre (0,52\% matéria seca) associado com dieta rica em carboidrato de alta fermentação e baixa quantidade de fibra efetiva. 


\section{REFERÊNCIAS}

Arthington J.D., Recheigl J.E., Yost G.P., Mcdowell L.R. \& Fanning M.D. 2002. Effects of ammonium sulfate fertilization on bahiagrass quality and copper metabolism in grazing beef cattle. J. Anim. Sci. 80:2507-2512.

Ahmad M.R., Allen V.G., Fontenot J.P. \& Hawkins G.W. 1995. Effect of sulfur fertilization on chemical composition, ensiling characteristics, and utilization by lambs of sorghum silage. J. Anim. Sci. 73:1803-1810.

Barros C.S.L., Driemeier D., Dutra I.S. \& Lemos R.A.A. 2006. Doenças do Sistema Nervoso de Bovinos no Brasil. Agnes, São Paulo, p.166-171.

Burgess, B.A. Polioencephalomalacia. 2008. Large Anim. Vet. 8(8):1-6.

Cebra C.K. \& Cebra M.L. 2004. Altered mentation caused by polioencephalomalacia, hypernatremia, and lead poisoning. Vet. Clin. North Am. Food Anim. Pract. 20(2):287-302.

Christian R.G. \& Tryphonas L. 1971. Lead poisoning in cattle: Brain lesions and hematologic changes. Am. J. Vet. Res. 32:203-216.

Claus P.C., Alfieri A.F. \& Alfieri A.A. 2002. Herpesvírus Bovino Tipo 5 e Meningoencefalite Herpética Bovina. Semina 23(1):131-141.

Claus M.P., Alfieri A.F., Folgueras-Flatschart A.V., Wosiacki S.R., Médici K.C. \& Alfieri A.A. 2005. Rapid detection and differentiation of bovine herpesvirus 1 and 5 glycoprotein $\mathrm{C}$ gene in clinical specimens by multiplex-PCR. J. Virol. Meth. 128:183 -188.

Coghlin C.L. 1944. Hydrogen sulphide poisoning in cattle. Can. J. Comparative Med. 8(4):111-113.

Coles E.H. 1984. Patologia Clínica Veterinária. 3 ed. Manole, São Paulo. 566p.

Colodel E.M., Nakazato L., Weiblen R., Mello R.M., Silva R.R.P., Souza M.A., Filho J.A.O. \& Caron L. 2002. Meningoencefalite necrosante em bovinos causada por herpesvírus bovino no estado de Mato Grosso do Sul, Brasil. Ciência Rural 32:293-298.

Cunha P.H.J., Badial P.R., Oliveira Filho J.P., Amorim R.L., Cagnini D.Q. \& Borges A.S. Intoxicação experimental por enxofre em bovinos Nelore. In: $2^{\circ}$ Encontro Nacional de Diagnóstico Veterinário, 2008, Campo Grande - MS. Anais do $2^{\circ}$ ENDIVET, 2008. p. 20-21.

Cunha P.H.J., Badial P.R., Oliveira Filho J.P., Cagnini Q.D., Marinheiro M.F., Gorino A.C. \& Borges A.S. 2009a. Avaliação da concentração do sulfeto de hidrogênio ruminal utilizando tubos colorimétricos em bovinos criados extensivamente. Anais do $8^{\circ}$ Congresso Brasileiro de Buiatria. Belo Horizonte, BH. Ciên. Anim. Bras. (Supl. 1) 83-87. 
Cunha P.H.J., Delfiol D.J.Z., Cagnini Q.D., Badial P.R., Oliveira Filho J.P., Olivo G., Amorim R.M. \& Borges A.S. 2009b. Identificação molecular do herpesvirus bovino tipo 5 em um bovino confinado associado com diagnóstico diferencial Laboratorial de outras causas de polioencefalomalacia. Anais do $8^{\circ}$ Congresso Brasileiro de Buiatria. Belo Horizonte, BH. Ciên. Anim. Bras. (Supl. 1) 93-98.

David N., Hübner S.O., Riet-Correa F., Danisa H. \& Lemos R.A. 2007. Reactivation of latent bovine herpesvirus type 5 in cattle with polioencephalomalacia induced by ammonium sulphate. Pesq. Vet. Bras. 27(10):435-441.

Dewhurst R. J., Kim E.J., Evans R.T., Cabrita A.R.J. \& Fonseca A.J.M. 2007. Effects of dietary sulphur sources on concentrations of hydrogen sulphide in the rumen head-space gas of dairy cows. Animal 1(4): 531-535.

Dirksen G., Grunder H.D. \& Stober M. 1993. Exame clínico dos bovinos. 3 ed. Guanabara Koogan, Rio de Janeiro. 419p.

Edwin E.E. \& Jackman, R. 1981. Nature of the autofluorescent material in cerebrocortical necrosis. J. Neurochem. 37(4):1054-1056.

Elias F., Schild A.L. \& Riet-Correa F. 2004. Meningoencefalite e polioencefalomalacia por herpesvírus bovino-5: distribuição das lesões no sistema nervoso central de bovinos naturalmente infectados. Pesq. Vet. Bras. 24(3):123-131.

Ferreira F.A., Coelho H.E. \& Bastos J.E.D. 1986. Polioencefalomalácia em bovinos no estado de Minas Gerais. Arq. Bras. Med. Vet. Zootec. 38:693-700.

Gonçalves R.C., Viana L., Sequeira J.L., Bandarra E.P., Chiacchio S.B. \& Kuchembuck M.R.G. 2001. Aspectos clínicos, anatomopatológicos e epidemiológicos da polioencefalomalácia em bovinos, na região de Botucatu, SP. Vet. Not. 7(2):54-57.

Gooneratne S.R., Olkowski A.A., Klemmer R.G., Kessler G.A. \& Christensen D.A. 1989. High sulfur related thiamine deficiency in cattle: a field study. Can. Vet. J. 30(2):139-146.

Gould D.H., Mcallister M.M., Savage J.C. \& Hamar D.W. 1991. High sulfide concentrations in rumen fluid associated with nutritionally induced polioencephalomalacia in calves. Am. J. Vet. Res. 52(7):1164-1169.

Gould D.H., Cummings B.A. \& Hamar D.W. 1997. In vivo indicators of pathologic ruminal sulfide production in steers with diet-induced polioencephalomalacia. J. Vet. Diag. Invest. 9(1):72-76.

Gould D.H. 1998. Polioencephalomalacia. J.Anim. Sci. 76(1):309-314.

Gould D.H. 2000. Update on sulphur-related polioencephalomalacia. Vet. Clin. North Am. Food Anim. Pract. 16(3):481-496. 
Gunn M.F., Baird J.D. \& Wilkie J.S.N. 1987. Accidental sulfur poisoning in a group of Holstein heifers. Can. Vet. J. 28(4):188-192.

Hamlen H., Clark E. \& Janzen E. 1993. Polioencephalomalacia in cattle consuming water with elevated sodium sulfate levels: A herd investigation. Can. Vet. J. 34(3):153-158.

Haydock D. 2003. Sulfur-induced polioencephalomalacia in a herd of rotation cattle. Can. Vet. J. 44(10):828-829.

Jeffrey M., Duff J.P., Higgins R.J., Simpson V.R., Jackman R., Jones T.O., Mechie S.C. \& Liversey C.T. 1994. Polioencephalomalacia associated with the ingestion of ammonium sulphate by sheep and cattle.Vet. Rec. 134(14):343-348.

Jensen R., Griner L.A. \& Adams O.R. 1956. Polioencephalomalacia of cattle and sheep. J. Am. Vet. Med. Assoc. 129:311-321.

Klasing K.C., Goff J.P., Greger J.L. \& King J.C. 2005. Mineral tolerance of animals. $2^{\text {nd }}$ rev.edn. The Nacional Academics Press, Washington DC, p.372-385.

Kul O., Karahan S., Basalan M. \& Kabakcl N. 2006. Polioencephalomalacia in cattle: a consequence of prolonged feeding barley malt sprouts. J. Vet. Med. Assoc. 53(3):123-128.

Lemos R.A.A., Nakazato L., Barros C.S.L., Gattas C.B.A. \& Bonilla R. 1997. Meningoencefalite eosinofílica em bovinos no estado do Mato Grosso do Sul. Arq. Inst. Biol. 64 (Supl.1): 43.

Lemos R.A.A., Driemeier D., Guimarães E.B., Dutra I.S., Mori A.E. \& Barros C.S.L. 2004. Lead poisoning in cattle grazing pasture contaminated by industrial waste. Vet. Hum. Toxicol. 46(6):326-328.

Lemos R.A.A. 2005. Enfermidades do sistema nervoso de bovinos de corte das regiões CentroOeste e Sudeste do Brasil. Tese de Doutorado, Universidade Estadual Paulista, Jaboticabal, SP. $150 \mathrm{p}$.

Lemos R.A.A. \& Riet-Correa F. 2007. Polioencefalomalacia, p.658-670. In: Riet-Correa F., Schild A.L., Lemos R.A.A. \& Borges J.R.J. (Eds), Doenças de Ruminantes e Eqüídeos. Vol.2. $3^{\mathrm{a}}$ ed. Pallotti, Santa Maria.

Linklater K.A., Dyson D.A. \& Morgan K.T. 1977. Faecal thiaminase in clinically normal sheep associated with outbreaks of polioencephalomalacia. Res. Vet. Sci. 22(3):308-312.

Lima E.F., Riet-Correa F., Tabosa I.M., Dantas A.F.M., Medeiros J.M. \& Sucupira Júnior G. 2005. Polioencefalomalacia em caprinos e ovinos na região semi-árida do Nordeste do Brasil. Pesq. Vet. Bras. 25(1):9-14.

Little P.B. 1978. Identity of fluorescence in polioencephalomalacia.Vet. Rec. 103(4):76.

Low J.C., Scott P.R., Howie F., Lewis M., FitzSimons J. \& Spence J.A. 1996. Sulphur-induced polioencephalomalacia in lambs.Vet. Rec. 138(14):327-329. 
Loneragan G.H., Gould D.H., Callan R.J., Sigurdson C.J. \& Hamar D.W. 1998. Association of excess sulfur intake and an increase in hydrogen sulfide concentrations in the ruminal gas cap of recently weaned beef calves with polioencephalomalacia. J. Am. Vet. Med. Assoc. 213:15991604.

Loneragan G.H., Wagner J.J., Gould D.H., Garry F.B. \& Thoren M.A. 2001. Effects of water sulfate concentrations on performance, water intake, and carcass characteristics of feedlot steers. J. Anim. Sci. 79(12): 2941-2948.

Loneragan G.H., Gould D.H., Wagner J., Garry F. \& Thoren M. 2005. The magnitude and patterns of ruminal hydrogen sulfide production, blood thiamine concentration, and mean pulmonary arterial pressure in feedlot steers consuming water of different sulfate concentrations. The Bovine Practitioner 39(1):16-22.

Lunardi M., Claus M.P., Lisboa J.A.N., Amude A.M., Headley S.A., Alfieri A.F. \& Alfieri A.A. 2009. Neurological and epidemiological aspects of a BoHV-5 meningoencephalitis outbreak. Braz. Arch. Biol. Technol. 52:77-85.

McKenzie R.A., Carmichael A.M., Schibrowski M.L., Duigan S.A., Gibson J.A. \& Taylor J.D. Sulfur-associated polioencephalomalacia in cattle grazing plants in the family Brassicaceae. Austr. Vet. J. 87(1,2):27-32.

Markson L.M., Edwin E.E., Lewis G. \& Richardson C. 1974. The production of cerebrocortical necrosis in ruminant calves by the intraruminal administration of amprolium. Brit. Vet. J. 130(1):9-16.

Mayhew I.G. Large Animal Neurology: A Handbook for Veterinary Clinics.1989. Lea \& Febiger, London. 379p.

Mcallister M.M., Gould D.H. \& Raisbeck M.F. 1997. Evaluation of ruminal sulfide concentrations and seasonal outbreaks of polioencephalomalacia in beef cattle in a feedlot. J. Am. Vet. Med. Assoc. 211(10):1275-1279.

Mella C.M., Perez-Oliva O., Loew F.M. 1976. Induction of bovine polioencephalomalacia with feeding system based on molasses and urea. Can. J. Comp. Med. 40(1):104-110.

Mendes L.C.N., Borges A.S., Peiró J.R., Feitosa F.L.F. \& Anhesini C.R. 2007. Estudo retrospectivo de 19 casos de polioencefalomalácia, em bovinos, responsivos ao tratamento com tiamina. Arq. Bras. Med. Vet. Zootec. 59(1):239-241.

Miguel M.P., Souza M.A., Brum K.B., Jorge P.H.C., Porto R.R.N.G. \& Brito L.A.B. 2005. Freqüência de casos de polioencefalomalacia em bovinos encaminhados ao Setor de Patologia Animal da Escola de Veterinária da Universidade Federal de Goiás - UFG no período de jan/2003 a mar/2005. Arq. Bras. Med. Vet. Zootec. 57(Supl.1):72. 
Morgan K.T. 1974. Amprolium poisoning of preruminant lambs: An ultrastructural study of the cerebral malacia and the nature of the inflammatory response. J. Pathol. 112:229-236.

Moro L., Nogueira R.H.G., Carvalho A.U. \& Marques D.C. 1994. Relato de três casos de polioencefalomalacia em bovinos. Arq. Bras. Med. Vet. Zootec. 46(4):409-416.

Nakazato L., Lemos R.A.A. \& Riet-Correa F. 2000. Polioencefalomalacia em bovinos nos estados de Mato Grosso do Sul e São Paulo. Pesq. Vet. Bras. 20(3):119-125.

Niles G.A., Morgan S.E. \& Edwards W.C. 2000. Sulfur-induced polioencephalomalacia in stocker calves. Vet. Human Toxicol. 42(5):290- 291.

Niles G.A., Morgan S., Edwards W.C. \& Lalman D. 2002. Effects of dietary sulfur concentrations on the incidence and pathology of polioencephalomalacia in weaned beef calves. Vet. Human Toxicol. 44(2):70-72.

Osweiler G.D., Carr T.F., Sanderson T.P., Carson T.L. \& Kinker J.A. 1995. Water deprivationsodium ion toxicosis in cattle. J. Vet. Diagn. Invest. 7:583-585.

Owens F. 2007. Acidose clínica e subclínica. Anais do $3^{\circ}$ Simpósio de nutrição de ruminantes, Botucatu, SP, p.157-173. (Palestra).

Pritchard D. \& Eggleston G.W. 1978. Nardoo fern and polioencephalomalacia. Austr. Vet. J. 54(4):204-205.

Putrino S.M., Leme P.R., Luz e Silva S., Manella M.Q., Nogueira Filho J.C.M. Lima C.G. \& Alleoni G.F. 2007. Digestibilidade aparente de dietas com níveis crescentes de concentrado em novilhos Brangus e Nelore. Arq. Bras. Med. Vet. Zootec. 59(2):406-413.

Radostitis O.M., Gay C.C., Hinchcliff K.W. et al. (Eds). 2007. Veterinary Medicine: A Textbook of the Diseases of Cattle, Horses, Sheep, Pigs, and Goats. 10a ed. W.B. Saunders, Philadelphia. p.724-725.

Raisbeck M.F. 1982. Is polioencephalomalacia associated with high-sulfate diets? J. Am. Vet. Med. Assoc. 180(11):1303-1305.

Riet-Correa G., Duarte M.D., Barbosa J.D., Oliveira C.M.C., Cerqueira V.D., Brito M.F. \& Riet-Correa F. 2006. Meningoencefalite e polioencefalomalacia causada por Herpesvírus bovino-5 no Estado do Pará. Pesq. Vet. Bras. 26(1):44-46.

Rissi D.R., Oliveira F.N., Rech R.R., Pierezan F., Lemos R.A.A. \& Barros C.S.L. 2006. Epidemiologia, sinais clínicos e distribuição das lesões encefálicas em bovinos afetados por meningoencefalite por herpesvírus bovino-5. Pesq. Vet. Bras. 26(2):123-132.

Rissi D.R., Rech R.R., Flores E.F. Kommers G.D. \& Barros C.S. 2007. Meningoencefalite por herpesvírus bovino-5. Pesq. Vet. Bras. 27(7):251-260. 
Rissi D.R., Pierezan F., Sá e Silva M., Flores E.F. \& Barros C.S.L. 2008. Neurological disease in cattle in southern Brazil associated with Bovine herpevirus infection. J. Vet. Diagn. Invest. 20(3):346-349.

Rousseaux C.G., Olkowski A.A., Chauvet A., Gooneratne S.R. \& Christenson D.A. 1991. Ovine polioencephalomalacia associated with dietary sulphur intake. J. Vet. Med. A. 38(3):229-239.

Sager R.L., Hamar D.W. \& Gould D.H. 1990. Clinical and biochemical alterations in calves with nutritionally induced polioencephalomalacia. Am. J. Vet. Res. 51(12):1969-1974.

Salvador S.W.C., Lemos R.A.A., Riet-Correa F., Roehe P.M. \& Osório A.L.A.R. 1998. Meningoencefalite em bovinos causada por herpesvírus bovino-5 no Mato Grosso do Sul e São Paulo. Pesq. Vet. Bras. 18(2):76-83.

Sampaio I.B.M. 1998. Estatística Aplicada à Experimentação Animal. UFMG, Belo Horizonte. $221 \mathrm{p}$.

Sanches A.W.D., Langohr I.M., Stigger A.L. \& Barros C.S.L. 2000. Doenças do sistema nervoso central em bovinos no Sul do Brasil. Pesq. Vet. Bras. 20(3):113-118.

Sant'ana F.J.F., Rissi D.R., Lucena R.B., Lemos R.AA, Nogueira A.P.A. \& Barros C.S.L. 2009a. Polioencefalomalacia em bovinos: epidemiologia, sinais clínicos e distribuição das lesões no encéfalo. Pesq Vet. Bras. 297(7):487-497.

Sant'ana F.J.F., Lemos R.AA, Nogueira A.P.A., Togni M., Tessele B. \& Barros C.S.L. 2009b. Polioencefalomalacia em ruminantes. Pesq. Vet. Bras. 29(9):681-694.

Sant'ana F. J. F., Nogueira A.P.A., Souza R.I.C., Cardinal S.G., Lemos R.AA \& Barros C.S.L. 2009c. Polioencefalomalacia experimental induzida por amprólio em ovinos. Pesq. Vet. Bras. 29(9):747-752.

Santos M.N., Jardim Filho J.O. \& Grando F.A. 1983. Polioencefalomálacia em bovinos no Rio Grande do Sul. Pesq. Vet. Bras. 3:37-39.

Sousa R.S. \& Irigoyen L.F. 1999. Intoxicação experimental por Phalaris angusta (Gramineae) em bovinos. Pesq. Vet. Bras. 19(3,4):116-122.

Stöber M. 1993. Sistema nervoso central. In: Rosemberg, G. (Ed), Exame Clínico dos Bovinos. Guanabara Koogan; Rio de Janeiro, 421p.

Traverso S.D., Colodel E.M., Loretti A.P., Seitz A.L., Correa A.M., Krauspenhar C. \& Driemeier D. 2001. Polioencefalomalacia em bovinos leiteiros no Rio Grande do Sul suplementados com enxofre. $10^{\circ}$ ENAPAVE, Pirassununga, p.72. (Resumo).

Traverso S.D., Loretti A.P., Donini M.A. \& Driemeier D. 2004. Lead poisoning in cattle in southern Brazil. Arq. Bras. Med. Vet. Zootec. 56(3):418-421.

Trueman K.F. \& Clague D.C. 1978. Sodium chloride poisoning in cattle. Austr. Vet. J. 54(2):89-91. 
Valadares Filho S.C., Pina D.S. \& Chizzotti M.L. 2006. Degradação ruminal da proteína dos alimentos e síntese de proteína microbiana. In: Valadares Filho S.C., Paulino P.V.R., Magalhães K.A. (Eds), Exigências Nutricionais de Zebuínos e Tabelas de Composição de Alimentos BRCorte. Suprema Gráfica, Viçosa, MG. 142p. 
Quadro 1. Momentos em que foram realizados os exames físicos, as colheitas de amostras de sangue total e de fluido ruminal e as dosagens de sulfeto de hidrogênio ruminal $\left(\mathrm{H}_{2} \mathrm{~S}\right)$ dos bovinos do grupo que ingeriu ração sem sulfato de sódio (G1) e do que consumiu ração com sulfato de sódio (G2) nas três fases do protocolo de indução experimental de polioencefalomalacia em bezerros mestiços.

\begin{tabular}{ccccc}
\hline Fases & Exame físico & Sangue & $\mathbf{H}_{2}$ S ruminal & Fluido ruminal \\
& $($ dia $)$ & $($ dia $)$ & $($ dia $)$ & (dia) \\
\hline 1 & $1^{\circ}, 7^{\circ} \mathrm{e} 14^{\circ}$ & $1^{\circ} \mathrm{e} 14^{\circ}$ & $1^{\circ}, 7^{\circ} \mathrm{e} 14^{\circ}$ & $1^{\circ}, 7^{\circ} \mathrm{e} 14^{\circ}$ \\
3 & $7^{\circ}$ & $7^{\circ}$ & $7^{\circ}$ & $7^{\circ}$ \\
\hline
\end{tabular}




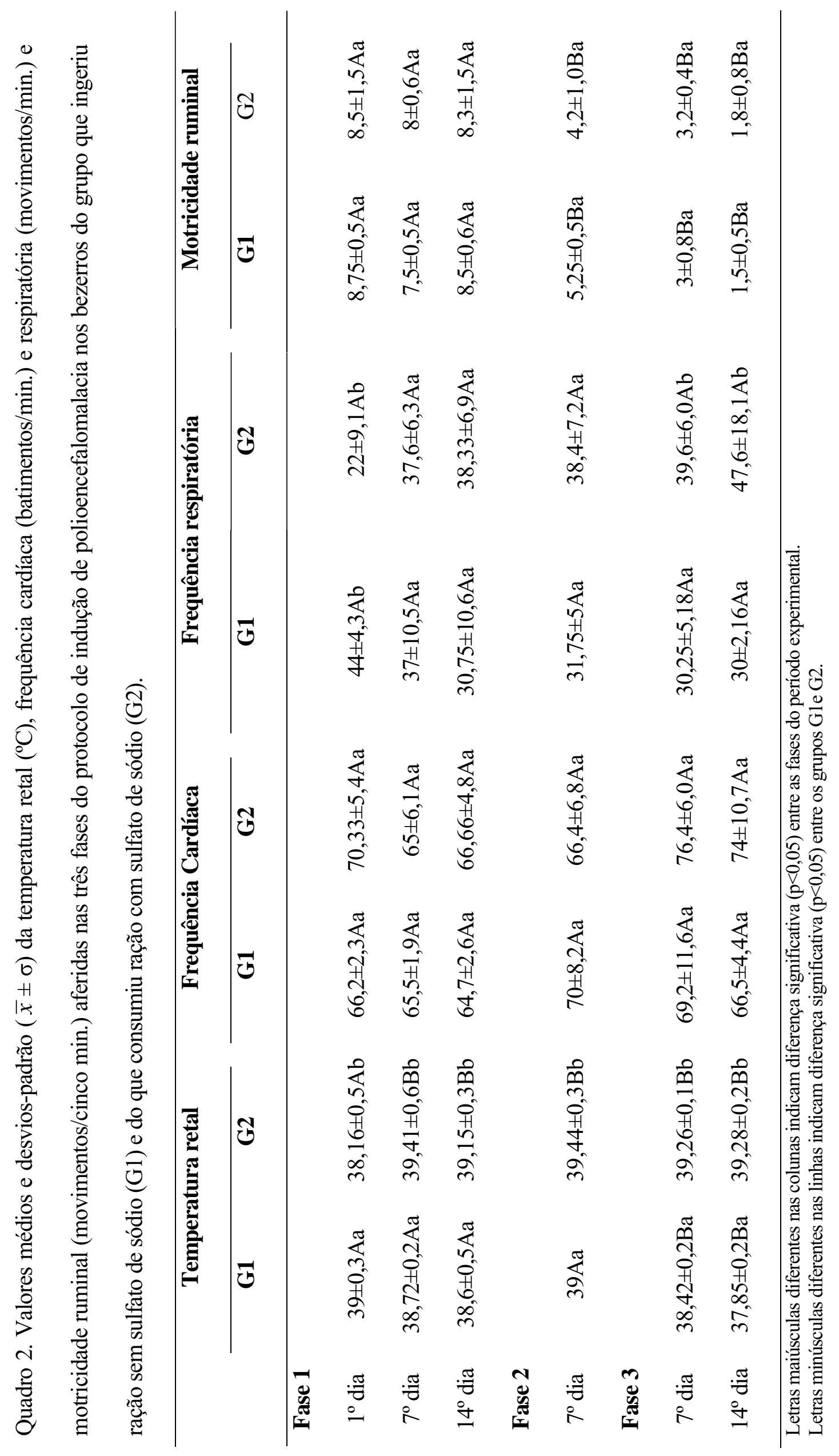




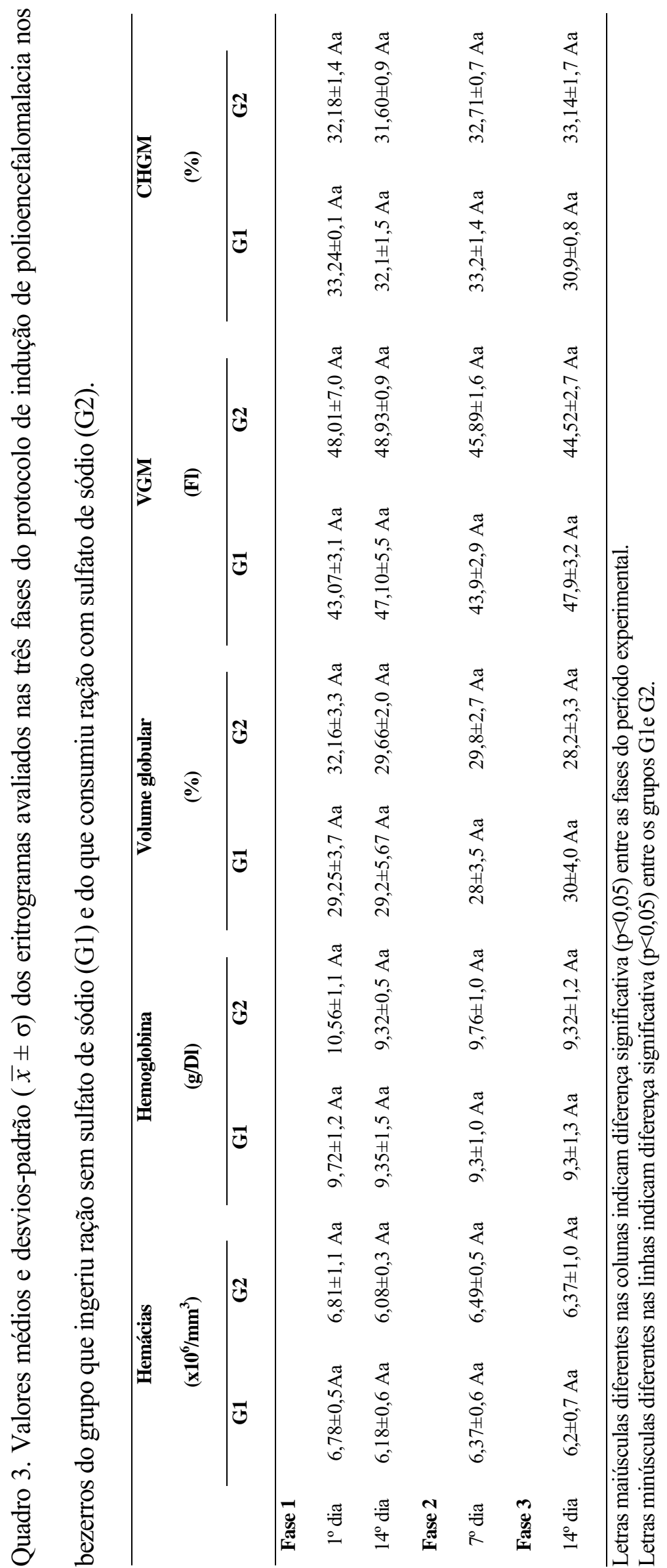




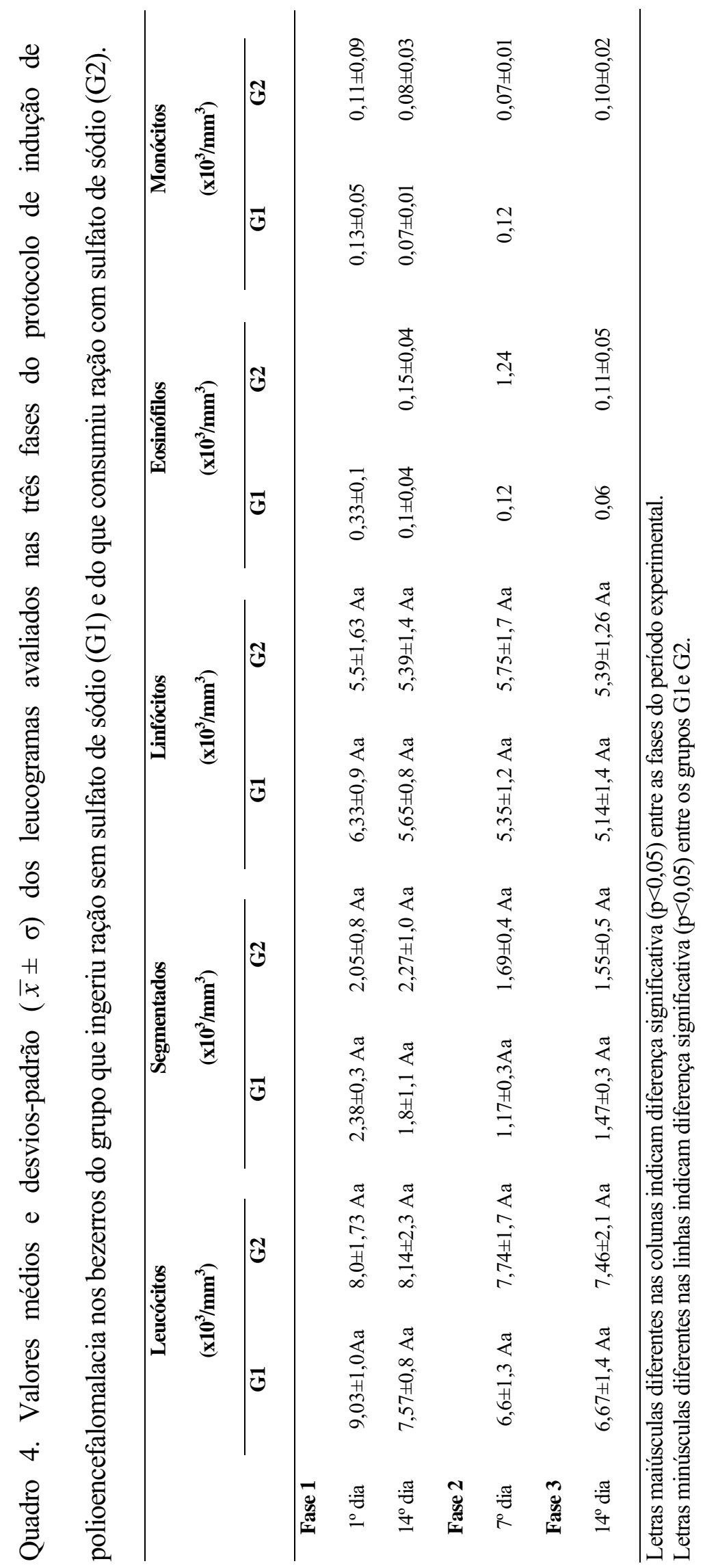


Quadro 5. Valores médios e desvios-padrão $(\bar{x} \pm \sigma)$ do fibrinogênio plasmático $(\mathrm{g} / \mathrm{dL})$ e proteína plasmática (mg/dL) avaliados nas três fases do protocolo de indução de polioencefalomalacia nos bezerros do grupo que ingeriu ração sem sulfato de sódio (G1) e do que consumiu ração com sulfato de sódio (G2).

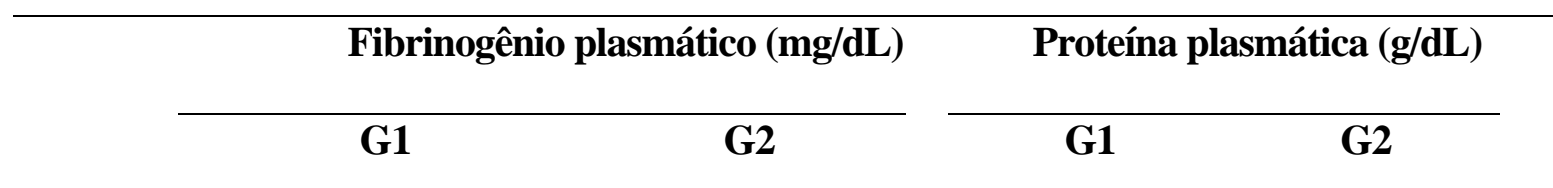

\section{Fase 1}

$\begin{array}{ccccc}1^{\circ} \mathrm{dia} & 150 \pm 57,7 \mathrm{Aa} & 300 \pm 109,5 \mathrm{Aa} & 8,1 \pm 0,2 \mathrm{Aa} & 6,88 \pm 0,2 \mathrm{Ab} \\ 14^{\circ} \mathrm{dia} & 250 \pm 100 \mathrm{Aa} & 266,66 \pm 103,2 \mathrm{Aa} & 7,15 \pm 0,34 \mathrm{Ba} & 6,33 \pm 0,7 \mathrm{Ab}\end{array}$

Fase 2

$7^{\circ} \mathrm{dia} \quad 250 \pm 100 \mathrm{Aa} \quad 440 \pm 89,4 \mathrm{Aa} \quad 6,9 \pm 0,11 \mathrm{Ba} \quad 7,0 \pm 0,2 \mathrm{Aa}$

Fase 3

$14^{\circ} \mathrm{dia} \quad 450 \pm 100 \mathrm{Aa} \quad 360 \pm 89,4 \mathrm{Aa} \quad 7,65 \pm 0,3 \mathrm{Aa} \quad 6,84 \pm 0,1 \mathrm{Ab}$

$\overline{\text { Letras maiúsculas diferentes nas colunas indicam diferença significativa }(\mathrm{p}<0,05) \text { entre as fases do período experimental. }}$ Letras minúsculas diferentes nas linhas indicam diferença significativa $(p<0,05)$ entre os grupos G1e G2. 
Quadro 6. Valores médios e desvios-padrão $(\bar{x} \pm \sigma)$ do sulfeto de hidrogênio ruminal (ppm) avaliados nas três fases do protocolo de indução de polioencefalomalacia nos bezerros do grupo que ingeriu ração sem sulfato de sódio (G1) e do que consumiu ração com sulfato de sódio (G2).

G1 G2

\begin{tabular}{lcc}
\hline Fase 1 & \\
$1^{\circ}$ dia & $24 \mathrm{Aa}$ & $46 \pm 51 \mathrm{Aa}$ \\
$7^{\circ}$ dia & $1.300 \pm 621,82 \mathrm{Ba}$ & $128,83 \pm 149,99 \mathrm{Aa}$ \\
$14^{\mathrm{o}}$ dia & $1.725 \pm 618,46 \mathrm{Ba}$ & $1.255 \pm 928,15 \mathrm{Aa}$ \\
Fase 2 & & \\
$7^{\circ}$ dia & $47,25 \pm 35,45 \mathrm{Aa}$ & $803,33 \pm 610,39 \mathrm{Aa}$ \\
Fase 3 & $73,5 \pm 44,22 \mathrm{Aa}$ & $3.900 \pm 1.282,57 \mathrm{Bb}$ \\
$3^{\circ}$ dia & $50,5 \pm 53 \mathrm{Aa}$ & $3.900 \pm 2.284,73 \mathrm{Bb}$ \\
$7^{\circ}$ dia & $205 \pm 57,44 \mathrm{Aa}$ & $3.960 \pm 1.289,57 \mathrm{Bb}$ \\
$10^{\circ}$ dia & $49,75 \pm 20,82 \mathrm{Aa}$ & $3.240 \pm 1.533,94 \mathrm{Bb}$ \\
\hline $14^{\circ}$ dia & & \\
\hline
\end{tabular}

Letras maiúsculas diferentes nas colunas indicam diferença significativa $(p<0,05)$ entre as fases do períod
Letras minúsculas diferentes nas linhas indicam diferença significativa $(p<0,05)$ entre os grupos G1e G2. 
Quadro 7. Valores médios e desvios-padrão $(\bar{x} \pm \sigma)$ do $\mathrm{pH}$ ruminal avaliados nas três fases do protocolo de indução de polioencefalomalacia nos bezerros do grupo que ingeriu ração sem sulfato de sódio (G1) e do que consumiu ração com sulfato de sódio (G2).

\section{pH ruminal}

G1 G2

\section{Fase 1}

$1^{\circ}$ dia

$7,06 \pm 0,12 \mathrm{ACa}$

$6,90 \pm 0,23 \mathrm{Aa}$

$7^{\mathrm{o}} \mathrm{dia}$

$6,91 \pm 0,20 \mathrm{ACa}$

$6,88 \pm 0,34 \mathrm{Aa}$

$14^{\circ}$ dia

$6,59 \pm 0,22 \mathrm{Aa}$

$6,73 \pm 0,16 \mathrm{Aa}$

Fase 2

$7^{\circ}$ dia

$6,56 \pm 0,24 \mathrm{Aa}$

$6,78 \pm 0,16$ Aa

Fase3

$7^{\circ}$ dia

$6,8 \pm 0,32 \mathrm{ACa}$

$6,66 \pm 0,21 \mathrm{Aa}$

$14^{\mathrm{o}} \mathrm{dia}$

$7,15 \pm 0,19 \mathrm{BCa}$

$6,87 \pm 0,27 \mathrm{Aa}$

Letras maiúsculas diferentes nas colunas indicam diferença significativa $(\mathrm{p}<0,05)$ entre as fases do período experimental. Letras minúsculas diferentes nas linhas indicam diferença significativa $(\mathrm{p}<0,05)$ entre os grupos G1e G2. 
Quadro 8. Valores individuais da contagem das hemácias, do total e diferencial das células nucleadas, dos teores de glicose $(\mathrm{mg} / \mathrm{dL})$ liquórica e sérica e proteína $(\mathrm{mg} / \mathrm{dL})$ das amostras do líquido cefalorraquidiano colhidas no final da 3 fase do protocolo de indução de polioencefalomalacia nos bezerros do grupo que consumiu ração com sulfato de sódio (G2).

\begin{tabular}{cccccc}
\hline Parâmetros & \multicolumn{5}{c}{ Bovinos (G2) } \\
Hemácias (células/ $\mu \mathrm{L})$ & 4 & 6 & 7 & 8 & 9 \\
\cline { 2 - 6 } Células nucleadas (células/ $\mu \mathrm{L})$ & 1 & 6 & $<1$ & 2 & $<1$ \\
Neutrófilos (\%) & 2 & 0 & 4 & 0 & 0 \\
Células mononucleares (\%) & 5 & 6 & 4 & 8 & 1 \\
Linfócitos (\%) & 2 & 40 & 92 & 48 & 0 \\
Macrófagos (\%) & 3 & 54 & 0 & 44 & 0 \\
Glicose (mg/dL) & 51 & 32 & 33 & 33 & 41 \\
Proteínas totais (mg/dL) & 28,1 & 17,5 & 15,2 & 34,6 & 13,3 \\
\end{tabular}


Quadro 9. Valores individuais da dosagem de chumbo realizada nos fragmentos de tecido hepático $(\mu \mathrm{g} / \mathrm{g})$ e renal $(\mu \mathrm{g} / \mathrm{g})$ colhidas do bezerro 10 do grupo que ingeriu ração sem sulfato de sódio $(\mathrm{G} 1)$ e dos bezerros 1, 4 e 7 do que consumiram ração com sulfato de sódio (G2)

\begin{tabular}{cccccc}
\hline Tecido & G1 & & \multicolumn{3}{c}{ G2 } \\
\cline { 2 - 3 } \cline { 5 - 6 } & 10 & & 1 & 4 & 7 \\
Hepático $(\mu \mathrm{g} / \mathrm{g})$ & 0,24 & & $<0,05$ & 0,068 & 0,27 \\
Renal $(\mu \mathrm{g} / \mathrm{g})$ & 0,13 & & $<0,05$ & 0,05 & 0,16 \\
\hline
\end{tabular}



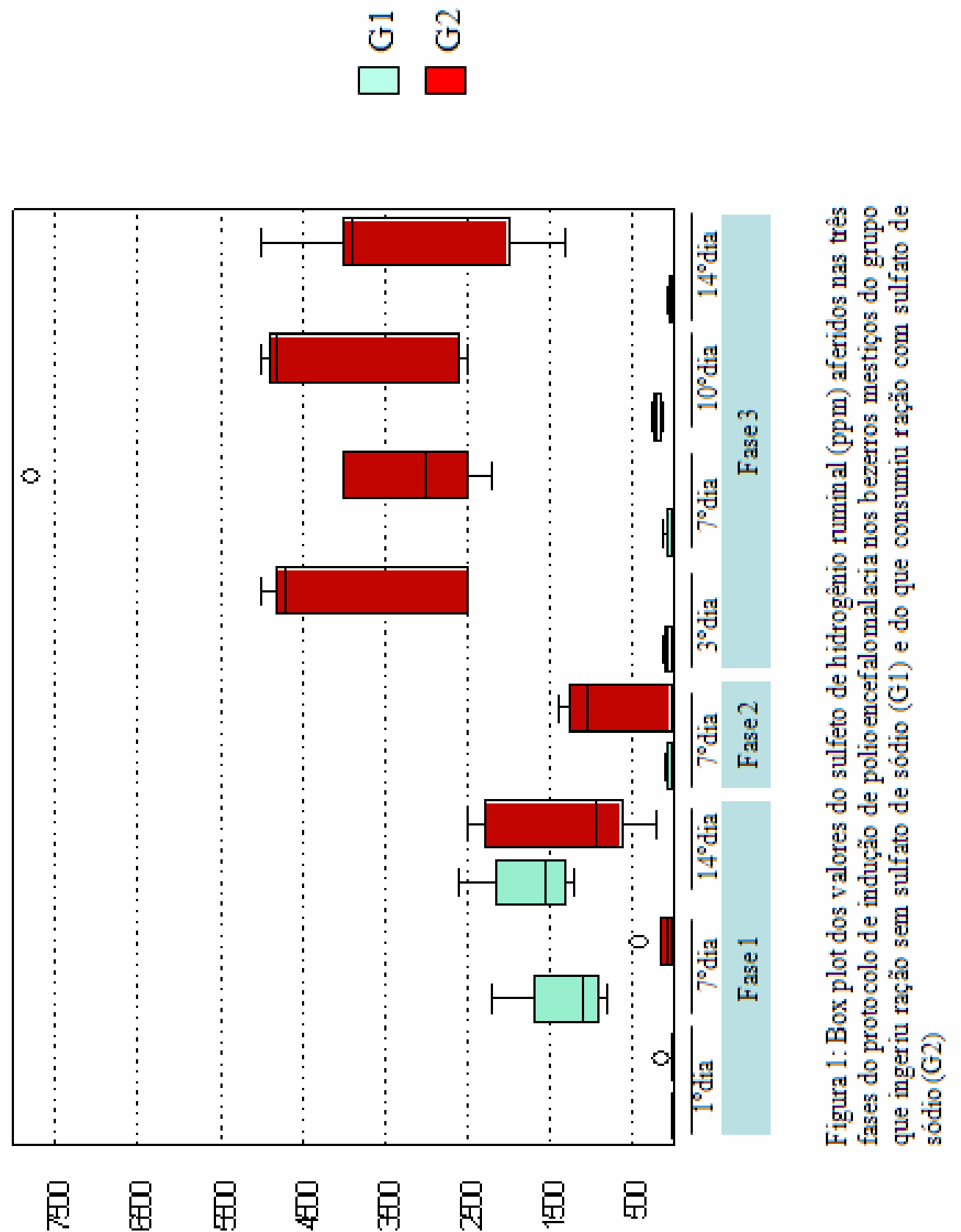

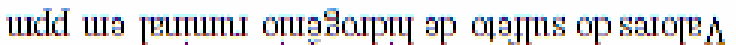




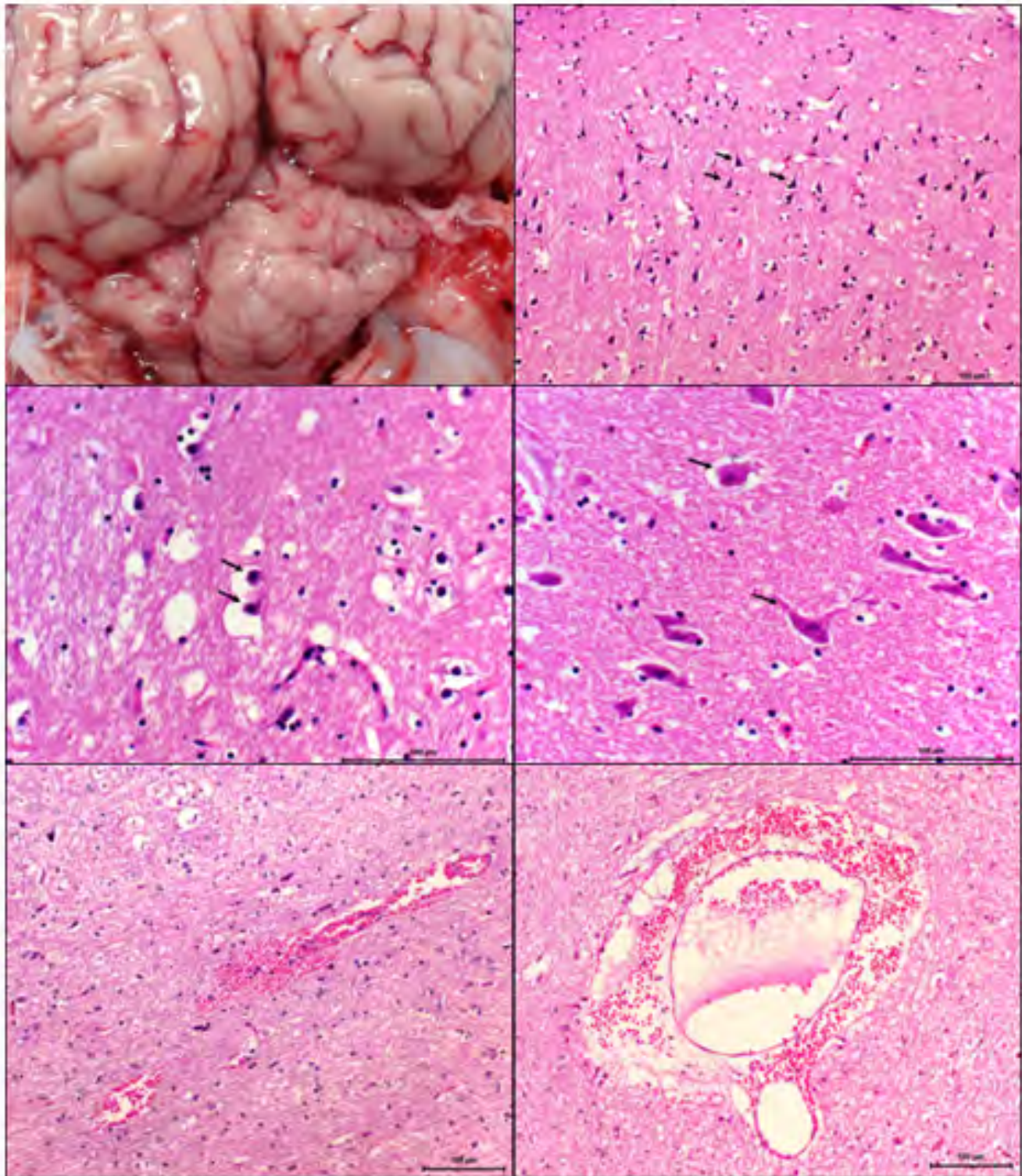

Figura 2. Bezerro 1. Edema do córtex parietal e occipital (achatamento dos giros cerebrais) comprimindo a porção lateral esquerda do cerebelo.

Figura 3. Bezerro 1. Córtex parietal esquerdo. Presença de neurônios vermelhos (setas). HE, obj. $20 \mathrm{x}$.

Figura 4. Bezerro 1. Núcleos da base. Edema (vacúolos) e necrose neuronal (setas). HE, obj. 40x. Figura 5. Bezerro 1. Tálamo. Presença de neurônios vermelhos (setas). HE, obj. 40x

Figura 6. Bezerro 7. Ponte. Áreas de hemorragia perivascular. HE, obj. 20x.

Figura 7. Bezerro 7. Bulbo. Area de hemorragia ao redor do vaso sanguineo. $\mathrm{HE}$, obj. 20x 
CAPITTULOIII 
Trabalho a ser enviado para a revista Pesquisa Veterinária Brasileira.

Polioencefalomalacia em bezerros induzida por inoculação experimental com herpesvirus bovino 5 (Polioencephalomalacia in calves induced by experimental infection with bovine herpesvirus 5)

ABSTRACT: Bovine herpesvirus $5(\mathrm{BoHV}-5)$ is an important cause of polioencephalomalacia (PEM) in cattle from different Brazilian geographical regions. In this study, calves were infected with BoHV-5 to induce experimental PEM. Six crossbred calves were infected with $0.5 \mathrm{~mL}$ of virus suspension $\left(10^{7,2}\right.$ $\mathrm{TCID}_{50} / \mathrm{mL}$ ) in each nasal cavity. During the 30 days of experimental postinfection (p.i.), calves were clinically evaluated (retal temperature, cardiac and respiratory rates and ruminal motricity) and laboratorial (hematology, plasma fibrinogen, total protein, ruminal fluid $\mathrm{pH}$, ruminal hydrogen sulfide concentration, cerebrospinal fluid, gross and histopathological). Virus detection was investigated in six brain regions, trigeminal ganglia and cerebrospinal fluid (CSF) by polimerase chain reaction (PCR) assay. One of the six calves developed signs of neurological disease beginning at day 12 and died 6 hours later. The other five animals remained asymptomatics and were euthanized at the end of experimental period. Cardiac and respiratory rate, plasma fibrinogen, total protein, ruminal fluid $\mathrm{pH}$ and hydrogen sulfide concentration were within references ranges, but the rectal temperature tended to increase between days 9 and 11 p.i. Alterations in erythrogram and leukogram were slight and unspecific. It was possible to verify CSF pleocytosis in all symptomatic and asymptomatic calves. The BoHV-5 DNA was detected in several brain areas and in the trigeminal ganglia and PCR was positive in CSF only in the symptomatic animal. The histology revealed cerebrocortical necrosis and non suppurative encephalitis and meningitis. PEM was induced in calves by experimental infection with BoHV-5 and can remain asymptomatic.

INDEX-TERMS: cerebrocortical necrosis, BoHV-5, cattle, experimental model, diagnosis. 
RESUMO: O herpesvirus bovino 5 (BoHV-5) é uma importante causa de polioencefalomalacia (PEM) em bovinos nas diferentes regiões do Brasil. O objetivo do trabalho foi induzir PEM em bezerros pela inoculação experimental com BoHV-5. Seis bezerros foram inoculados com o BoHV-5 pela via intranasal com instilação de $0,5 \mathrm{~mL}$ do inóculo em cada narina, totalizando uma dose viral de $10^{7,2} \mathrm{DICT}_{50} / \mathrm{mL}$ ). Durante os 30 dias pós inoculação (p.i.) experimental, exames clínicos (temperatura retal, frequência cardíaca e respiratória e motricidade ruminal) e laboratoriais (hemograma, fibrinogênio plasmático e proteína plasmática, $\mathrm{pH}$ fluido ruminal, concentração do sulfeto de hidrogênio ruminal, líquido cerebrospinal e histopatológico) foram realizados. A presença do vírus foi investigada em seis porções do encéfalo, no gânglio do trigêmeo e no líquido cefalorraquidiano (LCR) pela reação em cadeia da polimerase (PCR). Um bezerro apresentou sinais neurológicos começando no $12^{\circ}$ dia p.i., vindo a óbito após seis horas. Os outros cinco bezerros permaneceram assintomáticos e foram eutanasiados no final do período experimental. A frequência respiratória e cardíaca, a motricidade ruminal, o fibrinogênio e proteína plasmática, o $\mathrm{pH}$ do fluido ruminal e os valores da concentração do sulfeto de hidrogênio ruminal estavam dentro dos valores de referência. A temperatura retal exibiu uma tendência a se elevar entre o $9^{\circ}$ e $11^{\circ}$ dias p.i. As alterações no eritrograma e no leucograma foram discretas e inespecíficas. No LCR foi possível identificar pleocitose no bezerro sintomático e nos assintomáticos. O DNA do BoHV-5 foi identificado em várias porções do encéfalo, nos gânglios do trigêmeo e no LCR do bezerro no momento em que apresentou encefalopatia. Microscopicamente observaram- se necrose cerebrocortical, encefalite e meningite não supurativa. A infecção experimental com o BoHV-5 ocasionou polioencefalomalacia nos bezerros, podendo ser assintomática.

INDEX-TERMS: necrose cerebrocortical, BoHV-5, bovino, modelo experimental, diagnóstico. 


\section{INTRODUÇÃO}

O herpesvirus bovino 5 (BoHV-5) é um alfaherpesvírus associado à infecções neurológicas acompanhadas de meningoencefalite (Rissi et al. 2008, Del Médico Zajac et al. 2009) e considerado como um dos agentes etiológicos da polioencefalomalacia (PEM) em bovinos no Brasil (Barros et al. 2006, Riet-Correa et al. 2006, Rissi et al. 2007, Sant'Ana et al. 2009ab) e na Argentina (Perez et al. 2003). No Brasil, depois da raiva, o BoHV-5 é considerado como uma das principais causas virais de encefalopatia nos bovinos e a ocorrência da doença tem aumentado (Lisboa et al. 2009), com casos e/ou surtos reportados no Estado de Goiás (De Paula et al. 2005), no Mato Grosso do Sul e São Paulo (Salvador et al. 1998), Minas Gerais (Botelho 2000), São Paulo (Cunha et al. 2009a), São Paulo e Minas Gerais (Gomes et al. 2002), Rio Grande do Sul (Riet-Correa et al. 1989, 1996, Weiblen et al. 1989, Sanches et al. 2000, Elias et al. 2004, Rissi et al. 2006, Silva et al. 2007, Rissi et al. 2007, 2008), Mato Grosso (Colodel et al. 2002), Minas Gerais (Gomes et al. 2002, Aquino Neto et al. 2009), Pará (Riet-Correa et al. 2006) e Paraná (Claus et al. 2007, Lisboa et al. 2009, Lunardi et al. 2009).

A polioencefalomalacia (PEM) é uma doença cerebrocortical degenerativa dos ruminantes sendo o termo utilizado para indicar lesão de necrose laminar do córtex cerebral possuindo vários fatores associados a sua ocorrência (Gould 1998, 2000, Cebra \& Cebra 2004, Burguess 2008, Santana et al. 2009ab).

$\mathrm{Na}$ literatura internacional e nacional as outras causas de PEM relatadas são: intoxicação por enxofre (Raisbeck 1982, Gunn et al. 1987, Gooneratne et al. 1989, Sager et al. 1990, Hamlen et al. 1993, Jeffrey et al. 1994, McAllister et al. 1997, Loneragan et al. 1998, Gould 1998, 2000, Niles et al. 2000, 2002, Gould et al. 2001, Loneragan et al. 2001, Traverso et al. 2001, Haydock 2003, Loneragan et al. 2005, Kul et al. 2006, Dewhurst et al. 2007, McKenzie et al. 2009, Sant'Ana et al. 2009b), deficiência da tiamina (Jensen et al. 1956, Edwin \& Jackman 1973, Santos et al. 1983, 
Gonçalves et al. 2001, Mendes et al. 2007), intoxicação por sal associada à privação de água (Trueman \& Clague 1978, Osweiler et al. 1995, Lemos et al. 1997, Nakazato et al. 2000), alterações bruscas na dieta (Moro et al. 1994), intoxicação por chumbo (Christian \& Tryphonas 1971, Lemos et al. 2004, Traverso et al. 2004), ingestão de melaço (Mella et al. 1976) e ingestão de plantas ricas em tiaminases (Pritchard \& Eggleston 1978).

Considerando as diversas causas da PEM e a semelhança clínica entre elas (Claus et al. 2002, Elias et al. 2004, Barros et al. 2006), o diagnóstico ante-mortem é difícil de ser estabelecido, visto que essas enfermidades não possuem sinais patognomônicos, podendo ser confundida com qualquer outro quadro de encefalopatia. Desta forma, os métodos laboratoriais são de importância fundamental para o diagnóstico diferencial entre os agentes etiológicos da PEM.

A literatura nacional é escassa em relação às alterações hematológicas e liquóricas e valores da dosagem de sulfeto de hidrogênio ruminal como métodos complementares que possam auxiliar no diagnóstico diferencial da PEM causada pela ingestão excessiva de enxofre ou pela infecção como o BoHV-5. Além disso, quando se investigou a possível relação entre a PEM e encefalite por BoHV-5 (Elias et al. 2004, David et al. 2007) foi observado a indução de PEM por meio da administração de amprólio ou enxofre em bovinos previamente inoculados com BoHV-5.

O objetivo do trabalho foi avaliar aspectos clínicos e laboratoriais da indução da necrose cerebrocortical em bovinos pela inoculação experimental com o BoHV-5. 


\section{MATERIAL E MÉTODOS}

Foram utilizados seis bezerros mestiços leiteiros, machos, de 8 meses de idade, com peso entre $80-100 \mathrm{~kg}$ e mantidos durante 30 dias em um piquete. Os animais recebiam água e capimelefante (Pennisetum purpureum, Schum.) cv. Napier triturado à vontade. Foram excluídos do experimento os animais que apresentavam anticorpos séricos contra o herpesvírus bovino, detectados pela técnica de vírus neutralização (Ferreira et al. 2005, Dias et al. 2008).

A análise bromatológica do capim elefante (30,87\% matéria seca; 5,63\% proteína bruta; $2,11 \%$ extrato etéreo; $8,2 \%$ minerais; $42,86 \%$ fibra bruta; $80,65 \%$ extrato não nitrogenado; $48,35 \%$ nutrientes digestíveis totais; $80,65 \%$ fibra detergente neutra; $48,86 \%$ fibra detergente ácida) foi realizada no Laboratório de Bromatologia do Departamento de Melhoramento e Nutrição animal da Faculdade de Medicina Veterinária e Zootecnia da Universidade Estadual Paulista "Júlio de Mesquita Filho" (FMVZ/UNESP/Botucatu).

As análises de elementos minerais do capim elefante $(10 \mathrm{~g} / \mathrm{Kg}$ de nitrogênio; $2,2 \mathrm{~g} / \mathrm{Kg}$ de fósforo; $10 \mathrm{~g} / \mathrm{Kg}$ de potássio; $4 \mathrm{~g} / \mathrm{Kg}$ cálcio; 3,2 g/Kg de magnésio; $1,3 \mathrm{~g} / \mathrm{Kg}$ de enxofre; $12 \mathrm{mg} / \mathrm{Kg}$ de boro; $6 \mathrm{mg} / \mathrm{Kg}$ de cobre; $135 \mathrm{mg} / \mathrm{Kg}$ de ferro; $28 \mathrm{mg} / \mathrm{Kg}$ de manganês; $34 \mathrm{mg} / \mathrm{Kg}$ de zinco) foi realizada no Laboratório de Nutrição Mineral de Plantas do Departamento de Recursos Naturais e Ciência do Solo da Faculdade de Ciências Agronômicas da UNESP/Botucatu. A dosagem de enxofre da água $(11 \mathrm{mg} / \mathrm{L})$ do poço semi-artesiano foi conduzida no Laboratório de Fertilizantes e Corretivos da Faculdade de Ciências Agronômicas da UNESP/Botucatu.

Os bezerros foram inoculados com o BoHV-5 pela via intranasal com instilação de $0,5 \mathrm{~mL}$ do inóculo em cada narina, totalizando uma dose viral de $10^{7,2} \mathrm{DICT}_{50} / \mathrm{mL}$. A estirpe viral utilizada foi a AA PAR (Souza et al. 2002) isolada do cérebro de um bovino apresentando sinais de encefalite cedida pelo Laboratório de Virologia Animal do Centro de Ciências Agrárias da Universidade 
Estadual de Londrina. O título viral, expresso em doses infecciosas para cultura de tecidos $50 \%$ $\left(\mathrm{DICT}_{50}\right)$ foi obtido segundo Reed e Muench (1938).

Os animais foram examinados diariamente no piquete avaliando-se temperatura retal, frequência cardíaca e respiratória, motricidade ruminal, presença de secreção nasal e/ou ocular e de sinais neurológicos. As amostras de sangue para realização do hemograma, fibrinogênio e proteína plasmática foram colhidas antes da inoculação (M0) e depois com intervalos de 96 horas, totalizando sete momentos (M1, M2, M3, M4, M5, M6 e M7). As dosagens do sulfeto de hidrogênio ruminal $\left(\mathrm{H}_{2} \mathrm{~S}\right.$ ou gás sulfídrico) e as aferições do $\mathrm{pH}$ ruminal foram realizadas semanalmente. As amostras do líquido cefalorraquidiano (LCR) dos bezerros foram colhidas nos dias $10^{\circ}, 17^{\circ} 24^{\circ}$ e $30^{\circ}$ pós-inoculação (p.i) ou quando os mesmos apresentassem sinais neurológicos.

As amostras de sangue total foram colhidas por venopunção da jugular em tubos contendo anticoagulante (EDTA) e submetidas à contagem de células em câmara hematimétrica de Neubauer, à determinação do volume globular pelo método do microhematócrito e à dosagem de hemoglobina pelo método da cianometahemoglobina, calculando-se posteriormente os índices hematimétricos (volume globular médio e concentração de hemoglobina globular média) (Coles 1984). A contagem diferencial de leucócitos foi realizada em 100 células em esfregaços sanguíneos corados pelo panótico rápido. Para mensuração do fibrinogênio utilizou-se a técnica de precipitação no tubo de microhematócrito a $56^{\circ} \mathrm{C}$, enquanto a proteína foi determinada diretamente pela refratometria (Coles 1984).

Para verificação da presença de anticorpos contra o herpesvírus bovino as amostras de soro sanguíneo obtidas foram conservadas a $-20^{\circ} \mathrm{C}$ e descongeladas unicamente para a realização do exame de vírus neutralização (Ferreira et al. 2005, Dias et al. 2008) realizado no Laboratório de Virologia Animal do Centro de Ciências Agrárias da Universidade Estadual de Londrina. 
As coletas de LCR foram realizadas segundo procedimento proposto por Mayhew (1989). Após sedação com 0,20 mg/kg/IV cloridrato de xilazina (Vibaxil 2\%, Virbac Saúde Animal, Jurubatuba, SP, Brasil), tricotomia e anti-sepsia com iodopovidona (PVPI) foi realizada punção na cisterna atlanto-occiptal com agulha "spinal" 20G x 3 1⁄2" (BD, CAT.408373, São Paulo, SP , Brasil).

As amostras de LCR foram coletadas em três tubos de ensaio estéreis sem EDTA. A amostra do segundo tubo foi congelada a $-80^{\circ} \mathrm{C}$ para a realização da $\mathrm{PCR}$ e uma fração da terceira amostra foi analisada no intervalo máximo de 15 min. após coleta. $\mathrm{O}$ número de leucócitos e hemácias por microlitro do LCR foi mensurado com o uso da câmara de Fuchs-Rosenthal. A contagem diferencial de leucócitos foi feita em lâminas preparadas por citocentrifugação (Citocentrífuga Citológica Microprocessada, 200D, CIENTEC, Piracicaba, SP, Brasil) e coradas com método Panótico (Instant Prov, NEWPRO, Pinhais, PR, Brasil). As proteínas (Sensiprot, Labtest Diagnóstica, Lagoa Santa, MG) e a glicose (Glicose Pap, Labtest Diagnóstica, Lagoa Santa, MG, Brasil) foram dosadas com kits comerciais, empregando o método colorimétrico, cujas leituras das reações foram realizadas em espectrofotômetro (Espectrofotômetro Digital B 44242, Micronal, São Paulo, SP, Brasil).

A técnica da dosagem de sulfeto de hidrogênio ruminal utilizada foi adaptada de Gould et al. (1997) com as modificações descritas a seguir. Inicialmente foi realizada a tricotomia da fossa paralombar esquerda e anti-sepsia com iodopovidona (PVPI), sendo que a punção ruminal foi realizada no ponto médio da porção mais dorsal da fossa paralombar esquerda utilizando-se agulha do cateter intravenoso 14G sem a cânula externa de teflon. Em seguida, foi encaixado ao conector da agulha um equipo intravenoso com $15 \mathrm{~cm}$ de comprimento, cortando e desprezando-se a extremidade com o gotejador. A ponta cortada do equipo adaptado foi acoplada ao tubo colorimétrico de dosagem de gás sulfídrico, que já estava previamente inserido na bomba manual de vácuo (modelo AP-20S, Sensidyne ${ }^{\circledR}$, Florida, EUA). As mensurações foram realizadas de acordo 
com o manual do fabricante da bomba de vácuo, padronizando em $100 \mathrm{~mL}$ de gás para valores entre 25 a 1.000 ppm (modelo 120 SF, Sensidyne ${ }^{\circledR}$, Florida, EUA) de sulfeto de hidrogênio com tempo de amostragem de 1,5 minutos. Nos momentos em que não ocorreu mudança na coloração do tubo, repetiu-se a dosagem e não detectando alteração foi estabelecido que o valor aferido estivesse abaixo do limite inferior de detecção do tubo ( $<25$ ppm de $\mathrm{H}_{2} \mathrm{~S}$ ruminal).

As amostras do conteúdo ruminal foram obtidas por meio de uma bomba de sucção a vácuo, acoplada a um recipiente de vidro e a sonda oroesofágica tipo Schambye e Sorensen (Dirksen et al. 1993). Para avaliação do $\mathrm{pH}$ ruminal (Phtek®, modelo pH100) os primeiros $200 \mathrm{~mL}$ foram desprezados para evitar contaminação pela saliva, sendo colhidos aproximadamente $100 \mathrm{~mL}$ de cada animal.

Os bovinos que vieram a óbito e os animais submetidos à eutanásia foram necropsiados. A eutanásia foi realizada utilizando cloridrato de xilazina $(0,10 \mathrm{mg} / \mathrm{Kg}$ por via intravenosa), tiopental sódico ( $8 \mathrm{mg} / \mathrm{Kg}$ por via intravenosa) e por último cloreto de potássio.

Amostras de tecido hepático e renal de todos os animais foram coletadas para dosagem de chumbo e encaminhadas para o Centro de Assistência Toxicológica (CEATOX) do Instituto de Biociências da UNESP/Botucatu.

Para o exame histopatológico foram colhidas as seguintes porções do sistema nervoso central (SNC): bulbo olfatório, córtex frontal (anterior) na altura do joelho do corpo caloso, córtex occipital (posterior), córtex parietal (dorso-lateral), núcleos basais, tálamo, mesencéfalo na altura dos colículos rostrais, ponte com pedúnculos cerebelares, bulbo na altura do óbex e cerebelo. Adicionalmente foram examinados em monobloco o gânglio de Gasser (trigêmeo), rete mirabile e hipófise $(\mathrm{GRH})$. As amostras foram fixadas em formol tamponado a 10\% para a realização do exame histopatológico.

$\mathrm{Na}$ análise histopatológica, a intensidade das lesões foi estabelecida, considerando lesão discreta (1) quando menos de $25 \%$ do tecido estava afetado, moderado (2) referente a alterações de 
25 a $50 \%$ e acentuadas (3) indicando comprometimento acima de 50\% do tecido avaliado. Os seguintes aspectos foram computados para a obtenção da intensidade das lesões: hemorragia, congestão, edema do neurópilo, infiltrado inflamatório, meningite, gliose focal, gliose difusa, neurônios vermelhos (neurônios com o citoplasma encolhido e eosinofílico e núcleo picnótico), neuronofagia, malacia (necrose do componente neuroectodérmico com manutenção das estruturas mesenquimais e infiltrado de macrófagos tumefeitos e com citoplasma espumoso [células Gitter]), e lesão residual (estruturas vasculares e células Gitter remanescentes, formando uma estrutura cavitária semelhante a um cisto). Cada um dos parâmetros avaliados foi relacionado à seção anatômica examinada, com o objetivo de determinar a localização das lesões produzidas pela doença no SNC. Adicionalmente, foram avaliados qualitativamente o tipo de infiltrado inflamatório e a presença de corpúsculos de inclusão intranucleares característicos de herpesvírus (Rissi et al. 2006, Sant'Ana et al. 2009a).

Encéfalo e gânglio trigêmeo de seis bovinos clinicamente saudáveis foram colhidos em um frigorífico localizado no município de Lençóis Paulistas, SP e fixados em formol a 10\% para controle histológico.

Para a realização da técnica da PCR foram utilizados amostras do líquor e fragmentos do SNC que estavam conservados a $-80^{\circ} \mathrm{C}$. Os fragmentos do encéfalo utilizados para detecção do DNA do BoHV-5 foram: bulbo olfatório, córtex frontal, córtex occipital, tálamo, gânglio do trigêmeo e núcleos basais.

As extrações de DNA das amostras de encéfalo e LCR foram realizadas utilizando os respectivos kits de extração, QIAamp ${ }^{\circledR}$ DNA Mini Kit (QIAGEN ${ }^{\circledR}$ cat $n^{\circ}$. 51304) e QIAamp MiniElute $^{\circledR}$ Vírus $\left(Q_{1 A G E N}{ }^{\circledR}\right.$ cat $\left.n^{\circ} .57704\right)$. A técnica da PCR foi realizada segundo Claus et al. (2005) com algumas modificações. Os "primers" utilizados foram B5 (senso) específico para BoHV-5 (5' - CGG ACG AGA CGC CCT TGG-3' NT 322-339) e primer anti-senso denominado Bcon (5'- AGT GCA CGT ACA GCG GCT CG-3' NT 519-538), que amplificaram fragmento 
com $159 \mathrm{pb}$ do gene da glicoproteína $\mathrm{C}$ do BoHV-5. Como controle positivo utilizou-se amostra AA PAR do BoHV-5, isolada do cérebro de um bovino apresentando sinais de encefalite cedida pelo Laboratório de Virologia Animal do Centro de Ciências Agrárias da Universidade Estadual de Londrina. Realizou-se a PCR com a enzima GoTaq ${ }^{\circledR}$ Green Master Mix (Promega, Madison, WI, USA). A reação foi padronizada para um volume final de $50 \mu \mathrm{l}$ e possuía $0,4 \mu \mathrm{M}$ de cada oligonucleotídeo iniciador (senso e anti-senso), $5 \mu \mathrm{lde}$ DNA, $25 \mu$ GoTaq $^{\circledR}$ Green Master Mix, 8\% DMSO (Sigma®) e água "nuclease-free" q.s.p. O processo de amplificação foi realizado em termociclador (Mastercycler ${ }^{\circledR}$ ep Eppendorf) de acordo com as seguintes condições de tempo e temperatura: 1 ciclo de 2 min a $95^{\circ} \mathrm{C}$ seguido por 40 ciclos de 40 segundos a $94^{\circ} \mathrm{C}$ (denaturação), 1 min com temperatura de hibridização de $57,8^{\circ} \mathrm{C}, 1$ min a $72^{\circ} \mathrm{C}$ (extensão) e um ciclo de extensão final de $5 \mathrm{~min}$ a $72^{\circ} \mathrm{C}$. Os produtos amplificados foram analisados por eletroforese em gel de agarose a $1,5 \%$, corado com GelRed ${ }^{\mathrm{TM}}$ (Biotium, Halward, CA, EUA) e visualizado sob luz ultravioleta. Os géis foram documentados no ImageQuant ${ }^{\circledR}$ (GE Healthcare).

Para a avaliação das diferenças entre as médias dos resultados obtidos, comparando entre os dias após inoculação, foram feitos os testes de análise de variância (ANOVA) para as amostras que apresentaram distribuição normal (temperatura retal, frequência cardíaca e respiratória, motricidade ruminal, leucograma, fibrinogênio plasmático, proteína plasmática e $\mathrm{pH}$ ruminal) e de KruskalWallis para os dados não paramétricos (células nucleadas, neutrófilos, células mononucleares, linfócitos, macrófagos e glicose do LCR) (Sampaio 1998). Para todos os resultados, foram consideradas significantes as análises que apresentaram $p \leq 0,05$. Para as avaliações estatísticas, foi utilizado o software estatístico GraphPad InStat versão 3.0 para Windows (GraphPad Software).

Todos os procedimentos realizados encontram-se de acordo com as normas e princípios éticos de experimentação animal, estabelecidos pela Câmara de Ética em Experimentação Animal da FMVZ/UNESP/Botucatu, sendo o experimento aprovado pela mesma (Protocolo nº117/2006CEEA). 


\section{RESULTADOS E DISCUSSÃO}

Os valores médios e desvios-padrão da temperatura retal, frequência cardíaca e respiratória e motricidade ruminal aferidos durante período de 30 dias nos seis bezerros mestiços após infecção experimental com o BoHV-5 estão apresentados no quadro 1 e foram verificadas diferenças significativas $(\mathrm{p}<0,05)$ na avaliação da temperatura retal no $9^{\circ}$ e $25^{\circ}$ dias e da frequência respiratória no $2^{\circ}$ e $13^{\circ}$ dias. Exceto a temperatura retal, os demais parâmetros físicos avaliados permaneceram dentro da faixa de normalidade para a espécie bovina (Radostits et al. 2007). Os valores mais elevados de temperatura retal $\left(40,5^{\circ} \mathrm{C}\right)$ foram identificados entre os dias 4 e 7 e 9 e 11 após inoculação (figura 1). Perez et al. (2002) e Isernhagen (2005) observaram elevação significativa da temperatura entre os dias 8 a 12 p.i.. Hübner et al. (2005) observaram moderada hipertermia no $3^{\circ}$ e $4^{\circ}$ dias p.i. A elevação de temperatura não é um achado constante nas inoculações experimentais por BoHV-5 (Meyer et al. 2001, Vogel et al. 2003) e em casos naturais (Perez et al. 2003). Neste estudo e nas inoculações experimentais realizadas por Perez et al. (2002), Hübner et al. (2005) e Isernhagem (2007), a elevação de temperatura observada não foi significativa para ocasionar febre.

Todos os animais apresentaram secreção nasal do $2^{\circ}$ ao $10^{\circ}$ dia, mantendo-se em alguns animais por vários dias, enquanto que em outros foi intermitente, inclusive em dois bezerros evoluiu para aspecto mucopurulento. Em um animal observou-se discreta secreção ocular no $15^{\circ}$ dia p.i. A secreção nasal é um sinal frequentemente relatado em bovinos acometidos naturalmente (Salvador et al. 1998, Sanches et al. 2000, Colodel et al. 2002, Rissi et al. 2006) ou inoculados experimentalmente com BoHV-5 (Belknap et al. 1994, Meyer et al. 2001, Perez et al. 2002, Vogel et al. 2003, Hübner et al. 2005, Isernhagen 2005). Presença de secreção ocular foi identificada somente em um bezerro, enquanto Isernhagen (2005) evidenciou em dois, mas em ambos os estudos o volume era pequeno. Na presente pesquisa não se notou nos animais sinais como tosse e comprometimento das vias áreas posteriores. Entretanto, Hübner et al. (2005) e Isernhagen (2005) 
descreveram que alguns bezerros exibiram tosse seca e esporádica, mas também não observaram comprometimento das vias áreas posteriores.

Durante o período de observação de 30 dias p.i. notou-se um bezerro (bovino 1) com sinais de encefalopatia (12 p.i.) e outro (bovino 2) foi encontrado morto no piquete pela manhã (21 p.i.). Os demais quatro animais não exibiram qualquer alteração neurológica e foram considerados assintomáticos. Ashbaugh et al. (1997) inocularam BoHV-5 em dois bezerros de 4 a 6 meses de idade e não observaram sinais neurológicos durante os 15 dias de avaliação. Cascio et al. (1999) não observaram sinais neurológicos em quatro bovinos com idade entre três a quatro meses, mesmo realizando administração de dexametasona 30 dias p.i. com o BoHV-5. Meyer et al. (2001) ao compararem a patogenia da infecção aguda e latente em bezerros inoculando BoHV-5 em animais entre 2,5 a 4 meses de idade, conseguiram induzir encefalopatia em sete animais de um grupo de oito bezerros. Perez et al. (2002) inocularam BoHV-5 em 23 bezerros com 12 meses de idade e observaram sinais de encefalopatia em apenas dois animais. Após oito dias da administração de dexametasona, identificaram outros quatro bezerros com sinais neurológicos. Vogel et al (2003) inocularam o BoHV-5 em 12 animais e somente observaram sinais de encefalopatia em três bezerros após sete dias depois da aplicação de dexametasona. Vogel et al. (2004) não observaram sinais neurológicos após inoculação com BoHV-5 em seis bezerros, mesmo realizando administração da dexametasona 60 dias após inoculação. Hübner et al. (2005) observaram sinais de encefalopatia em três bezerros com seis meses de idade de um total de seis inoculados. Isernhagen (2005) inoculou em sete bezerros com idade entre 20 e 58 dias e observou sinais neurológicos em quatro animais. Os trabalhos experimentais indicam diversidade de resultados quanto ao número de animais que apresentaram sinais de encefalopatia, evidenciando a dificuldade de induzir encefalopatia em todos os bezerros inoculados (Ashbaugh et al. 1997, Cascio et al. 1999, Perez et al. 2002). 
O aparecimento dos sinais de encefalopatia no bezerro 1 foi no $12^{\circ}$ p.i. e caracterizados inicialmente, por disfagia, convulsões localizadas e pleurótono. Após um intervalo de tempo de $6 \mathrm{~h}$, o bezerro apresentava ataxia, andar em círculos, andar compulsivo, evoluindo para decúbito com convulsões generalizadas e movimentos de pedalagem, sendo submetido à eutanásia in extremis. Perez et al. (2002) observaram alterações neurológicas semelhantes também no mesmo período após inoculação, enquanto Meyer et al. (2001) identificaram distúrbios encefálicos entre o $9^{\circ}$ e $14^{\circ}$ dias p.i. Hübner et al. (2005) relataram sinais de encefalopatia semelhantes ao descritos na presente pesquisa mas no 10 p.i., enquanto Isernhagen (2005) notou inicio dos sinais de encefalopatia entre o $9^{\circ}$ e $11^{\circ}$ dias p.i. Períodos de inoculação semelhantes a esses foram observados em infecções experimentais realizadas por Beltrão et al. (2002) e Caron et al. (2002) em coelhos. Silva et al. (1998) inocularam uma estirpe argentina do BoHV-5 em nove ovinos (grupo A) e uma estirpe brasileira (grupo B) em 12 ovinos. Foram observados sinais neurológicos caracterizados por depressão, bruxismo, tremores, ptialismo, incoordenação, andar em círculos, pleurótono e decúbito em apenas um ovino do grupo A e também após 10 dias p.i.. Pesquisas em bezerros experimentalmente infectados com BoHV-5 (Meyer et al. 2001, Perez et al. 2002, Vogel et al . 2003 e Isernhagen 2005) ou em casos naturais da doença (Salvador et al. 1998, Perez et al. 2003, RietCorrea et al. 2006, Lisboa et al. 2009, Aquino Neto et al. 2009, Lunardi et al. 2009) apesar de relatarem os mesmos sinais de encefalopatias, evidenciaram grande variabilidade da evolução dos sinais clínicos nos bezerros, ocorrendo relatos tanto de quadros superagudos ou de duração mais longa.

$\mathrm{Na}$ avaliação do eritrograma foram verificadas diferenças significativas $(p<0,05)$ nos valores de hemoglobina e volume globular entre o momento M0 com os outros avaliados (quadro 2). Os valores médios e desvios-padrão dos resultados do eritrograma dos bezerros estão dentro do padrão de referência (Radostits et al. 2007), exceto os resultados do bezerro 3 no momento M1, do animal 4 no M7 e do bezerro 5 no M3 e M7, onde constatou-se discreta anemia normocítica normocrômica. 
A anemia é um achado comum em animais que possuem infecção viral e o agente infeccioso raramente é o agente causador direto desta alteração, sendo que este tipo de anemia está correlacionado com processos inflamatórios com patogenia multifatorial (Jain 1993). Isernhagen (2005) não observou variações significativas no eritrograma dos bezerros experimentalmente inoculados com o BoHV-5. Lisboa et al. (2009) não observaram alterações significativas no eritrograma de animais naturalmente infectados com o BoHV-5, exceto aumento do volume globular em um animal devido hemoconcentração ocasionada pela disfagia.

Nos resultados dos constituintes dos leucogramas (quadro 3) não foram verificadas diferenças significativas $(p<0,05)$ entre os momentos avaliados e apresentaram valores dentro do intervalo de normalidade para a espécie (Radostits et al. 2007), exceto o bezerro 6 nos momentos M3 e M5, onde foi identificado leucocitose com neutrofilia, . Alteração semelhante no leucograma foi relatada por Isernhagen (2005), nos animais sintomáticos e coincidindo com o inicio da manifestação dos sintomas, enquanto nos bezerros assintomáticos nenhuma variação foi observada. Entretanto, no bezerro 1 foi colhida amostra de sangue no dia que apresentou sinais de encefalopatia (M2) e os resultados dos constituintes do leucograma estavam dentro dos valores normais de acordo com Radostits et al. (2007). Lisboa et al. (2009) observaram leucocitose com neutrofilia em alguns animais infectados naturalmente por BoHV-5, mas identificaram pneumonia simultaneamente com meningoencefalite.

Nos valores médios e desvio padrão do fibrinogênio e proteínas plasmáticas (quadro 4) dos bovinos inoculados não foram verificadas diferenças significativas $(p<0,05)$ entre os momentos avaliados e os resultados encontram-se dentro do intervalo de normalidade para a espécie (Radostits et al. 2007). Isernhagen (2005) observou que todos os bezerros que manifestaram sinais de encefalopatia exibiram hiperfibrinogemia, enquanto na presente pesquisa o bezerro sintomático apresentou valor normal e os assintomáticos, especificamente o bezerro 3 no momento M3 e o animal 4 no M5, apresentaram valores acima do considerado normal (800 mg/dL). 
Os resultados observados no hemograma da presente pesquisa não demonstraram alterações significativas e indicaram que a sua análise não é importante como método de diagnóstico da meningoencefalite pelo BoHV-5 (Lisboa et al. 2009). Entretanto, para Mayhew (1989) este exame ante-mortem pode ser uma ferramenta útil no diagnóstico diferencial das encefalopatias, especialmente nas meningoencefalites bacterianas onde se observa significativa leucocitose e neutrofilia.

A realização da sedação previa dos animais antes da coleta do LCR no espaço atlantoocciptal foi indicado, por Holbrook \& White (1992) e resultou em uma contenção química eficaz para a realização do procedimento de forma segura. Na coleta do LCR do bezerro 1 no momento que apresentava sinais de encefalopatia (M2) não foi realizado a sedação prévia porque esta conduta poderia agravar o quadro clínico (Scott 2004).

O critério para coleta da primeira amostra do LCR foi estabelecida a partir dos resultados obtidos por Isernhagen (2005), que realizou coletas seriadas em bezerros inoculados com o BoHV-5 com intervalos de $48 \mathrm{~h}$ e observou aumento significativo das células nucleadas quando os animais apresentaram hipertermia entre os dias 8 a 12 p.i. Na presente pesquisa, a temperatura retal dos bezerros apresentou tendência a assumir valores elevados em dois momentos, mas de forma mais significativa a partir do $8^{\circ}$ dia p.i., optando-se pela coleta no décimo dia. As demais amostras foram colhidas com intervalos de sete dias, pois Cunha et al. (2009b) ao realizarem a segunda coleta $96 \mathrm{~h}$ após a primeira punção observaram alterações na celularidade e nas proteínas no LCR indicando inflamação local.

No presente estudo detectaram-se os maiores valores de hemácias nos seguintes animais: 128 hemácias/ $\mu \mathrm{L}$ no bezerro 4 no $\mathrm{M} 1,1105$ hemácias/ $\mu \mathrm{L}$ no bezerro 1 no $\mathrm{M} 2$ e no bezerro 4 , respectivamente, 84.800 hemácias/ $\mu \mathrm{L}$ e 1.687 hemácias/ $\mu \mathrm{L}$ nos momentos M3 e M4. A amostra do bezerro 4 no momento M3 foi descartada da análise, pois de acordo com Stokol et al. (2009), 
amostras de LCR com contaminação de sangue, acima de 50.000 hemácias/ $\mu \mathrm{L}$, podem interferir na interpretação dos resultados das demais variáveis analisadas.

O quadro 5 apresenta os valores médios e desvios-padrão da contagem total e diferencial das células nucleadas, dos teores de glicose $(\mathrm{mg} / \mathrm{dL})$ e proteína $(\mathrm{mg} / \mathrm{dL})$ do LCR coletadas 10 dias p.i. (M1), 17 p.i. (M2), 24 dias p.i. (M3) e 30 p.i. (M4) nos bezerros inoculados com o BoHV-5. Na avaliação do LCR foi verificada diferença significativa $(p<0,05)$ somente nas células nucleadas do M1 com os demais momentos avaliados. Em todos os bezerros inoculados observou-se na primeira coleta (M1) que os valores médios permaneceram dentro do intervalo de normalidade (Scott 1995), enquanto nas demais coletas os resultados indicaram pleocitose. Se considerarmos que a comprovação da presença de inflamação no LCR é baseada primariamente na pleocitose (Tvedten 1987), tanto o bezerro que apresentou sinais neurológicos quanto os assintomáticos desenvolveram encefalite, corroborando com os resultados obtidos por Isernhagen (2005).

$\mathrm{Na}$ contagem diferencial das células nucleadas do LCR com pleocitose foi observado predomínio dos linfócitos, seguido por células mononucleares indiferenciadas, indicando achados tipicamente associados com infecção viral (Stokol et al. 2009). Na infecção experimental realizada por Isernhagen (2005), os valores médios da pleocitose foram em média 5 vezes mais altos do que o valor máximo verificado na presente pesquisa. Vários fatores podem estar associados com essa indução mais severa de encefalite observada por Isernhagen (2005), destacando-se a inoculação em animais mais jovens.

Os resultados da mensuração dos níveis de proteínas totais liquóricas foram detectados acima do normal (valores acima de $40 \mathrm{mg} / \mathrm{dL}$ ) somente na segunda coleta (quadro 5). Mas, o bezerro 1 no momento M2, bezerros 2 e 3 no M1 e bezerro 4 no M1 apresentaram valores acima do normal. Aumento da proteína do LCR indica a ocorrência de inflamação, principalmente quando associada à pleocitose (Freeman \& Raskin 2003) como observada nos bezerros 1 no momento M2. A hiperproteinorraquia acompanhada de pleocitose não foi observada em todos os bezerros e 
resultados semelhantes foram relatados por Isernhagen (2005), que só observou hiperproteinorraquia em um bezerro ao final de seu quadro clínico. Lisboa et al. (2009) observaram discreto aumento da proteína no LCR de bovinos naturalmente infectados com o BoHV-5. Os teores de glicose no LCR dos bovinos apresentaram em alguns momentos valores inferiores aos considerados normais por Stober (1993), mas sem variação significativa.

As alterações identificadas no LCR foram consistentes e significativas, especialmente com relação à celularidade e confirmam ante-mortem a presença de um processo inflamatório encefálico, corroborando com Isernhagen (2005) e Lisboa et al. (2009) de que a pleocitose com predomínio de células mononucleares foi um achado comum em bezerros sintomáticos e assintomáticos naturalmente e experimentalmente infectados por BoHV-5.

A soroconversão foi observada em todos os bezerros desenvolvendo títulos que variaram de 16 a 64. O único animal que não apresentou soroconversão foi o bezerro 1 que apresentou sinais de encefalopatia. Notou-se variação individual significativa em relação ao título alcançado e tempo necessário para atingi-lo, sendo necessários 16 dias p.i. para observar valor de título mais elevado (64). Isernhagen (2005) observou valores máximos de títulos semelhantes ao da presente pesquisa, mas foram necessários 21 dias p.i. para alcançá-los. Vogel et al. (2003) também observaram valores máximos de título de 64. Considerando que o bezerro sintomático apresentou sinais clínicos no 12 p.i. com evolução do quadro clinico de $6 \mathrm{~h}$, acredita-se que o tempo não tenha sido suficiente para o animal produzir resposta sorológica.

A detecção do DNA viral por meio da PCR nas amostras do LCR só foi possível na amostra do bezerro 1 e somente no momento em que o mesmo apresentou sinais neurológicos (M2). Isernhagen (2005) também só conseguiu confirmar a presença de DNA viral no líquor de dois bezerros que desenvolveram quadro de disfunções encefálicas e em ambos os casos em amostras coletadas no momento final da evolução da doença. Estes resultados enfatizam a importância da análise do LCR realizando-se a contagem total e diferencial das células e a concentração de proteína 
(D’Ângelo et al., 2009) associado com a detecção do DNA viral pela PCR, tornando-se um exame complementar útil e rápido para confirmação, ainda em vida, do diagnóstico etiológico dessa enfermidade (Isernhagen 2005, Lisboa et al. 2009, Lunardi et al. 2009). Apesar da sensibilidade da detecção do DNA do BoHV-5 pela PCR não ser alta, tem sido útil como método de diagnóstico da infecção natural por BoHV-5 em bovinos (Lunardi et al. 2009).

Os resultados da detecção do DNA viral obtido por meio da técnica da PCR nas diferentes porções do SNC estão apresentados no quadro 6. Os fragmentos do encéfalo (bulbo olfatório, córtex frontal, córtex occipital, tálamo) e o gânglio do trigêmeo foram utilizados para detecção do DNA do BoHV-5 porque foram os locais de maior intensidade de lesão observados no exame histopatológico do encéfalo de bovinos relatados de sete surtos e um caso isolado de meningoencefalite por BoHV-5 em bovinos no Rio Grande do Sul entre 2002 e 2004 (Rissi et al. 2006). No bezerro sintomático o DNA viral foi detectado nas seis porções do SNC colhidas (6/6), no bezerro 2 em quatro (4/6) e nos demais em três fragmentos do SNC (3/6). A detecção de DNA viral em bezerros assintomáticos também foi evidenciada por Isernhagen (2005). Nos bezerros inoculados detectaram-se DNA viral no córtex frontal em todos os bezerros (6/6), no tálamo, gânglio do trigêmeo e nos núcleos da base em quatro (4/6) e no bulbo olfatório e córtex occipital em dois (2/6). Estes resultados indicam que o BoHV-5 se distribui pelo encéfalo do hospedeiro mesmo na condição de infecção latente (Vogel et al. 2003, Isernhagen 2005). A detecção do DNA viral nos gânglios do trigêmeo também foi relatado por Ashbaugh et al. (1997) e Isernhagen (2005).

Na presente pesquisa e em relatos de infecção experimental (Meyer et al 2001, Isernhagen 2005) e natural (Colodel et al. 2002, Rissi et al. 2006) não foram identificadas lesões macroscópicas no encéfalo. No entanto, frequentemente são observados vários graus de lesões inflamatórias e degenerativas no encéfalo de bovinos experimentalmente (Ashbaugh et al. 1997, Perez et al. 2002, Vogel et al. 2003, Isernhagen 2005) e naturalmente (Salvador et al. 1998, Colodel et al. 2002, Elias et al. 2004, Riet-Correa et al. 2006, Rissi et al. 2006) infectados com o BoHV-5. 
O quadro 7 apresenta número de bezerros com lesão em cada área associado com a distribuição e valores médios com os desvios-padrão da intensidade das lesões histológicas das diferentes porções do SNC e no gânglio do trigêmeo após infecção experimental com o BoHV-5. Ao exame histopatológico, no córtex frontal (figura 2) do encéfalo do bovino utilizado como controle histológico foi identificado neurônios com núcleos grandes, vesiculosos, nucléolo evidente e citoplasma levemente basofilico. Ao comparar o córtex frontal do bezerro 1 (figura 3) com a mesma região do controle histológico, as principais alterações observadas foram caracterizadas por neurônios com núcleos picnóticos e citoplasma acidofílico encolhido e edema de neurópilo caracterizando quadro de necrose cerebrocortical e, consequentemente, polioencefalomalacia (Gould 1998, 2000, Perez et al. 2003, Riet-Correa et al. 2006).

O BoHV-5 é considerado a forma infecciosa da PEM (Riet-Correa et al. 2006, Rissi et al. 2006, 2007) e histologicamente as lesões indicam reação inflamatória caracterizada pela presença de infiltrado inflamatório mononuclear difuso, ausente no tálamo do bezerro utilizado como controle histológico (figura 4) e evidente na mesma porção anatômica no bezerro 1 (figura 5) associado a edema e degeneração axonal. A presença de manguitos perivasculares compostos por células mononucleares foi identificada no córtex frontal do bezerro 3 (figura 6) e nos núcleos da base (figura 7) do bezerro 4. No entanto, se sabe que esses achados, quando isolados, podem ser interpretados como incidentais, pois focos discretos de infiltrado mononuclear perivascular podem ser observados em 30\% dos encéfalos de bovinos normais (Rissi et al. 2007). Outras alterações identificadas, principalmente no tálamo do bezerro 2, foram áreas de hemorragia perivascular (figura 8) e malacia focal com presença de inúmeras células Gitter e hemorragia (figura 9). O bezerro com sinais de encefalopatias apresentou intensidade das lesões no SNC mais acentuadas do que os bezerros assintomáticos corroborando com Isernhagen (2005).

Os achados histológicos relatados no quadro 7 indicam meningoencefalite não supurativa necrosante e foram compatíveis com as descrições de infecções experimentais (Belknap et al. 1994, 
Meyer et al. 2001, Perez et al. 2002, Vogel et al 2003, Hübner et al 2005, Isernhagen 2005) e naturais (Salvador et al. 1998, Colodel et al. 2002, Elias et al. 2004, Riet et al. 2006, Rissi et al. 2006, Aquino Neto et al. 2009, Lunardi et al. 2009) por BoHV-5.

Na presente pesquisa a localização e intensidade das lesões no encéfalo dos bovinos foi mais acentuada no córtex frontal e parietal do telencéfalo (figura 10). Resultados semelhantes foram descritos em bovinos naturalmente (Salvador et al. 1998, Colodel et al. 2002, Elias et al. 2004, Rissi et al. 2006) e experimentalmente (Perez et al. 2002) afetados pelo BoHV-5. Diferenças na localização e severidade das lesões também foram relatadas por Isernhagen (2005). Além do córtex frontal e parietal do telencéfalo, lesões significativas também foram identificadas no tálamo corroborando com Perez et al. (2002) e Rissi et al. (2008).

O gânglio do trigêmeo é uma importante rota do BoHV-5 para acessar o SNC dos bovinos (Perez et al. 2002). A maioria dos relatos de surtos espontâneos de meningoencefalite por BoHV-5 não mencionam achados histopatológicos no gânglio do nervo trigêmeo (GT) (Riet-Correa et al. 1989, Salvador et al. 1998, Colodel et al. 2002, Elias et al. 2004, Rissi et al. 2006). Entretanto, alguns experimentos realizados com bovinos relatam a ocorrência de discreta ganglioneurite envolvendo o gânglio do trigêmeo e o nervo trigêmeo (Meyer et al. 2001, Perez et al. 2002, Isernhagen 2005). Na presente pesquisa não se observou qualquer tipo de alteração histopatológica nos gânglios do trigêmeo e no cerebelo.

A ausência de lesões no gânglio do trigêmeo associado com maior intensidade das alterações no encéfalo dos bovinos nas porções rostrais do telencéfalo fornecem fortes evidências de que a via olfatória foi a principal rota de invasão do vírus no SNC e não pelos pares de nervos cranianos. Características semelhantes quanto a localização das lesões foram descritas por Rissi et al. (2006) permitindo concluir que a via olfatória havia sido a rota de invasão do vírus no SNC dos bovinos acometidos por surtos espontâneos de BoHV-5. 
As inclusões intranucleares eosinofílicas em astrócitos e neurônios não foram identificadas na presente pesquisa e também não foram observados nos estudos experimentais desenvolvidos por Perez et al. (2002) e Isernhagen (2005). Em casos naturais da doença, as inclusões intranucleares eosinofílicas em astrócitos e neurônios foram descritas em todos os casos (d'Offay et al . 1995, Elias et al. 2004, Riet-Correa et al. 2006, Lunardi et al. 2009), na maioria dos casos (Salvador et al. 1998), ocasionalmente (Rissi et al. 2006, 2008) ou não foram encontradas (Aquino Neto et al. 2009). Apesar de Summers et al. (1995) descreverem que a presença de corpúsculos de inclusão é mais frequente em materiais bem conservados, na presente pesquisa o material coletado foi fixado imediatamente e mesmo assim não foi observado a presença de inclusões intranucleares eosinofílicas. Isto pode influenciar resultados referentes as amostras de materiais colhidos de bovinos em surtos, em que os encéfalos são enviados refrigerados por veterinários de campo e demoraram algum tempo até serem fixados em formol. Por esta razão consideram pouco confiável a presença ou não de corpúsculos de inclusão intranucleares para confirmação ou eliminação do diagnóstico de meningoencefalite pelo BoHV-5 (Rissi et al. 2006). Para Beltrão et al. (2000) e Caron et al. (2002) a presença de corpúsculos de inclusão e de leões de malacia está correlacionada com a neurovirulência entre as amostras de BoHV-5.

A relação entre casos de meningoencefalite por BoHV-5 ocasionando PEM é descrita em várias regiões do Brasil (Riet-Correa et al. 2006, Rissi et al. 2007) e evidências experimentais sugerem que agentes etiológicos como enxofre e o amprólio possam reativar infecções latentes por BoHV-5 em bovinos (David et al. 2007). Desta forma, é importante realizar diagnóstico diferencial entre as causas da PEM, por meio de métodos complementares, tais como, determinação da concentração do enxofre na dieta, dosagem de gás sulfídrico ruminal e estabelecimento da concentração do chumbo nos fragmentos de tecido hepático e renal.

Para cálculo do consumo de enxofre pelos bovinos verificou-se que a ingestão do capim foi de $2,5 \%$ do peso vivo representando a ingestão de $0,13 \%$ de enxofre na matéria seca. Para o cálculo 
da ingestão de enxofre na água foi estimado que um bovino de $120 \mathrm{Kg}$ mantido em temperatura ambiente de $28^{\circ} \mathrm{C}$ deve ingerir aproximadamente 20 litros de água por dia (Gould, 2000), totalizando o consumo de $220 \mathrm{mg}$ de enxofre por dia (0,022\% de enxofre). A ingestão de enxofre total (capim e água) foi de $0,15 \%$ na matéria seca, valor este dentro do nível recomendado por Klasing et al. (2005).

Os valores estabelecidos das concentrações de sulfeto de hidrogênio ruminal ao longo do período de observação de 30 dias p.i. nos bovinos inoculados (quadro 8) não foram acima de 100 ppm, indicando que os animais estavam consumindo enxofre em quantidades adequadas (Gould 2000). Cunha et al. (2009c) ao avaliaram a concentração de sulfeto de hidrogênio ruminal em bovinos Nelore saudáveis mantidos em pasto de Brachiaria decumbens com 0,15\% de enxofre na matéria seca apresentaram concentração máxima de 100 ppm de gás sulfídrico ruminal. Gould et al. (1997), Loneragan et al (1998) e Niles et al (2002) utilizaram metodologia semelhante de dosagem de $\mathrm{H}_{2} \mathrm{~S}$ ruminal em bovinos confinados e consideraram como valores normais concentrações inferiores a $500 \mathrm{ppm}$.

No presente trabalho, na avaliação do $\mathrm{pH}$ ruminal (quadro 9) não foram verificadas diferenças significativas $(p<0,05)$ entre os momentos avaliados e estão de acordo com os valores fisiológicos para dietas com alto conteúdo de fibra, variando entre 6,5 a 7,5 (Campos et al. 2006). Uma microbiota ruminal ativa e um $\mathrm{pH}$ próximo da neutralidade garantem um processo digestivo dinâmico e a geração de ácidos graxos e síntese de proteína microbiana adequada (Van Soest 1994).

As concentrações de chumbo nas amostras de tecido hepático e renal nos bezerros inoculados estão apresentadas no quadro 10 e encontram-se abaixo dos níveis considerados tóxicos por Lemos \& Riet-Correa (2007).

Para Elias et al. (2004) e Riet-Correa et al. (2006), a identificação de lesões profundas, caracterizadas por áreas de malacia no tálamo, núcleos da base e colículos rostral e caudal, pode sugerir que a encefalite ocasionada pelo BoHV-5 seja secundária a lesões prévias de PEM por 
enxofre ou amprólio. Em um trabalho experimental foi demonstrado que animais que tinham sido inoculados anteriormente com BoHV-5 desenvolviam meningoencefalite após a indução de polioencefalomalacia mediante a administração de amprólio ou sulfato de sódio (David et al. 2007). Entretanto, na presente pesquisa áreas de malacia de intensidade moderada foram identificadas no tálamo de dois bezerros e o consumo de enxofre e a produção de sulfeto de hidrogênio ruminal estavam dentro dos níveis considerados normais por Gould (2000). Isto enfatiza a importância do estabelecimento na rotina de métodos complementares para estabelecer o diagnóstico diferencial das encefalopatias dos bovinos e também melhor compreensão da etiopatogenia da PEM no Brasil.

As análises do LCR associadas com as descrições histopatológicas dos bezerros que não desenvolveram clínica confirmaram a ocorrência de processo inflamatório no encéfalo desses animais, de forma não progressiva e assintomática, podendo a forma latente da infecção ter se estabelecido em seguida à fase inicial (Isernhagen 2005). Possivelmente a estirpe viral utilizada na presente pesquisa pode ter tido elevada neuroinvasividade e pouca neurovirulência, favorecendo ocorrência da forma latente da infecção. Descrições semelhantes foram relatadas por Isernhagen (2005) ao analisar o LCR e o histopatológico das lesões do encéfalo dos bezerros assintomáticos. Ashbaugh et al. (1997), Cascio et al. (1999) e Perez et al. (2002) também descreveram lesões típicas de inflamação no SNC de bezerros assintomáticos, mas não avaliaram o LCR.

\section{CONCLUSÃO}

A infecção experimental com BoHV-5 ocasionou polioencefalomalacia nos bezerros, podendo ser assintomática. 


\section{REFERENCIAS}

Aquino Neto H.M., Carvalho A.U., Facury Filho E.J., Ferreira P.M., Barbosa-Stancioli E.F., Lobato Z.I.P., Alvarenga M.R., Serrano A.L., Martins R.A. \& Afonso D.A.F. 2009. Meningoencefalite por Herpesvirus bovino 5 em Minas Gerais: relato de caso clínico. Arq. Bras. Med. Vet. Zootec. 61(1):1-5.

Ashbaugh S.E., Thompson K.E., Belknap E.B., Schultheiss P.C., Chowdhury S. \& Collins J.K. 1997. Specific detection of shedding and latency of bovine herpesvirus 1 and 5 using a nested polymerase chain reaction. J. Vet. Diag. Invest. 9:387-394.

Barros C.S.L., Driemeier D., Dutra I.S. \& Lemos R.A.A. 2006. Doenças do Sistema Nervoso de Bovinos no Brasil. Agnes, São Paulo, p.166-171.

Beltrão N., Flores E.F., Weiblen R., Silva A.M., Roehe P.M. \& Irigoyen L.F. 2000. Infecção e enfermidade neurológica por Herpesvirus bovino 5 (BHV-5): coelhos como modelo experimental. Pesq. Vet. Bras. 20:144-150.

Belknap E.B., Collins J.K., Ayers V.K., Schultheiss P.C. 1994. Experimental infection of neonatal calves with neurovirulent Bovine herpesvirus type 1.3. Vet. Pathol. 31:358-365.

Botelho R.G.A. 2000. Desenvolvimento de testes de PCR para BoHV-5 e sua aplicação no diagnóstico de casos clínicos. Dissertação de Mestrado, Escola de Veterinária, Universidade Federal de Minas Gerais, Belo Horizonte, MG. 45p.

Britsch V. 1978. The modification of the infectious bovine rhinotracheitis virus serum neutralization test. Acta Vet. Scand. 19:497-505.

Burgess B.A. Polioencephalomalacia. 2008. Large Anim. Vet. 8(8):1-6.

Campos R., González F., Coldebella A. \& Cardoso F. 2006. Indicadores do ambiente ruminal e suas relações com a composição do leite e células somáticas em diferentes períodos da primeira fase da lactação em vacas de alta produção. Ciência Rural 36(2):525-530.

Caron L., Flores E.F., Weiblen R., Scherer C.F., Irigoyen L.F., Roehe P.M., Odeon A. \& Sur J.H. 2002. Latent infection by bovine herpesvirus type- 5 in experimentally infected rabbits: virus reactivation, shedding and recrudescence of neurological disease. Vet. Microbiol. 84:285-295.

Cascio K.E., Belknap E.B., Schultheiss P.C., Ames A.D. \& Collins J.K. 1999. Encephalitis induced by bovine herpesvirus 5 and protection by prior vaccination or infection with bovine herpesvirus 1. J. Vet. Diagn. Invest. 11:134-139. 
Cebra C.K. \& Cebra M.L. 2004. Altered mentation caused by polioencephalomalacia, hypernatremia, and lead poisoning. Vet. Clin. North Am. Food Anim. Pract. 20(2):287-302.

Claus M.P., Alfieri A.F. \& Alfieri A.A. 2002. Herpesvírus Bovino tipo 5 e Meningoencefalite herpética bovina. Semina 23(1):31-141.

Claus M.P., Alfieri A.F., Folgueras-Flatschart A.V., Wosiacki S.R., Medici K.C. \& Alfieri A.A. 2005. Rapid detection and differentiation of bovine herpesvírus 1 and 5 glycoprotein $\mathrm{C}$ gene in clinical specimens by multiplex-PCR. J. Virol. Meth. 128:183-188.

Claus M.P., Alfieri A.F., Médici K.C., Lunardi M. \& Alfieri A.A. 2007. Bovine herpesvirus 5 detection by virus isolation in cell culture and Multiplex-PCR in central nervous system from cattle with neurological disease in Brazilian herds. Braz. J. Microbiol 38:485-490.

Coles E.H. 1984. Patologia Clínica Veterinária. 3 ed. Manole, São Paulo. 566p.

Colodel E.M., Nakazato L., Weiblen R., Mello R.M., Silva R.R.P., Souza M.A., Filho J.A.O. \& Caron L. 2002. Meningoencefalite necrosante em bovinos causada por herpesvírus bovino no estado de Mato Grosso do Sul, Brasil. Ciência Rural 32:293-298.

Christian R.G. \& Tryphonas L. 1971. Lead poisoning in cattle: Brain lesions and hematologic changes. Am. J. Vet. Res. 32:203-216.

Cunha P.H.J., Delfiol D.J.Z., Cagnini Q.D., Badial P.R., Oliveira Filho J.P., Olivo G., Amorim R.M. \& Borges A.S. 2009a. Identificação molecular do herpesvirus bovino tipo 5 em um bovino confinado associado com diagnóstico diferencial Laboratorial de outras causas de polioencefalomalacia. Anais do $8^{\circ}$ Congresso Brasileiro de Buiatria. Belo Horizonte, BH. Ciên. Anim. Bras. (Supl. 1) 93-98.

Cunha P.H.J., Badial P.R., Oliveira Filho J.P., Passarelli D., Takahira R.K., Lisbôa J.A.N. \& Borges A.S. 2009b. Comparação dos parâmetros citológicos e bioquímicos do líquido cefalorraquidiano coletado em dois diferentes momentos de bovinos sadios. Ciência Rural (submetido).

Cunha P.H.J., Badial P.R., Oliveira Filho J.P., Cagnini Q.D., Marinheiro M.F., Gorino A.C. \& Borges A.S. 2009c. Avaliação da concentração do sulfeto de hidrogênio ruminal utilizando tubos colorimétricos em bovinos criados extensivamente. Anais do $8^{\circ}$ Congresso Brasileiro de Buiatria. Belo Horizonte, BH. Ciên. Anim. Bras. (Supl. 1) 83-87.

David N., Hübner S.O., Riet-Correa F., Danisa H. \& Lemos R.A. 2007. Reactivation of latent bovine herpesvirus type 5 in cattle with polioencephalomalacia induced by ammonium sulphate. Pesq. Vet. Bras. 27(10): 435-441. 
Del Médico Zajac M.P., Ladelfa M.F., Kotsias F., Muylkens B., Thiry J., Thiry E. \& Romera S.A. 2009. Biology of bovine herpesvirus 5. Vet. J. doi:10.1016/j.tvj1.2009.03.035. (in press).

De Paula R.R., Souza M.A., Colodel E.M., Hübner S.O., Brum K.B., Jorge K.B.C. \& Damasceno A.D. 2005. Meningoencefalite causada pelo BHV-5 em um bovino no Estado de Goiás. Arq. Bras. Med. Vet. Zoot. 57 (Supl.1):2.

Dewhurst R. J., Kim E. J., Evans R. T., Cabrita A.R. J. \& Fonseca A. J. M. 2007. Effects of dietary sulphur sources on concentrations of hydrogen sulphide in the rumen head-space gas of dairy cows. Animal 1(4): 531-535.

Dias J.A., Alfieri A., Médici K. C., Freitas J. C., Neto J. S. F. \& Müller E. E. 2008. Fatores de risco associados à infecção pelo herpesvírus bovino 1 em rebanhos bovinos da região Oeste do Estado do Paraná. Pesq. Vet. Bras. 28:161-168.

Dirksen G., Grunder H.D. \& Stober M. 1993. Exame clínico dos bovinos. 3 ed. Guanabara Koogan, Rio de Janeiro. 419p.

d'Offay J.M., Ely R.W., Baldwin C.A., Whitenack D.L., Stair E.L. \& Collins J.K. 1995. Diagnosis of encephalitic bovine herpesvirus type 5 (BHV-5) infection in cattle: virus isolation and immunohistochemical detection of antigen in formalin-fixed bovine brain tissues. J. Vet. Diag. Invest. 7:247-251.

Elias F., Schild A.L. \& Riet-Correa F. 2004. Meningoencefalite e encefalomalacia por herpesvírus bovino-5: distribuição das lesões no sistema nervoso central de bovinos naturalmente infectados. Pesq. Vet. Bras. 24:123-131.

Engels M. \& Ackermann M. 1996. Pathogenesis of ruminant herpesvirus infections. Vet. Microbiol. 53:3-15.

Ferreira M.C., Médici K.C., Alfieri A.F. \& Alfieri A.A. 2005. Desenvolvimento e avaliação de um ensaio imunoenzimático para o diagnóstico sorológico da infecção pelo herpesvírus bovino. Semina 26:363-372.

Freeman K.P. \& Raskin R.E. 2003. Citologia do sistema nervoso central, p.275-308. In: Raskin, R.E. \& Meyer, D.J. (Eds), Atlas de Citologia de Cães e Gatos. Roca, São Paulo.

Gonçalves R.C., Viana L., Sequeira J.L., Bandarra E.P., Chiacchio S.B. \& Kuchembuck M.R.G. 2001. Aspectos clínicos, anatomopatológicos e epidemiológicos da polioencefalomalácia em bovinos, na região de Botucatu, SP. Vet. Not. 7(2): 54-57. 
Gooneratne S.R., Olkowski A.A., Klemmer R.G., Kessler G.A. \& Christensen D. A. 1989. High sulfur related thiamine deficiency in cattle: a field study. Can. Vet. J. 30(2):139-146.

Gould D.H., Cummings B.A., Hamar D.W. 1997. In vivo indicators of pathologic ruminal sulfide production in steers with diet-induced polioencephalomalacia. J. Vet. Diag. Invest. 9(1):72-76

Gould D.H. 1998. Polioencephalomalacia. J.Anim. Sci. 76(1): 309-314.

Gould D.H. 2000. Update on sulphur-related polioencephalomalacia. Vet. Clin. North Am. Food Anim. Pract. 16(3):481-496.

Gould D.H., Mcallister M.M., Savage J.C. \& Hamar D.W. 1991. High sulfide concentrations in rumen fluid associated with nutritionally induced polioencephalomalacia in calves. Am. J. Vet. Res. 52(7):1164-1169.

Gomes L.I., Rocha M.A., Costa E.A., Lobato Z.I.P., Mendes L.C.N., Borges A.S., Leite R.C. \& Barbosa-Stancioli E.F. 2002. Detecção de herpesvírus bovino 5 (BoHV-5) em bovinos do sudeste brasileiro. Arq. Bras. Med. Vet. Zootec. 54:217-220.

Gunn M.F., Baird J.D. \& Wilkie J.S.N. 1987. Accidental sulfur poisoning in a group of Holstein heifers. Can. Vet. J. 28(4):188-192.

Hamlen H., Clark E. \& Janzen E. 1993. Polioencephalomalacia in cattle consuming water with elevated sodium sulfate levels: A herd investigation. Can. Vet. J. 34(3): 153-158.

Haydock D. 2003. Sulfur-induced polioencephalomalacia in a herd of rotation cattle. Can. Vet. J. 44(10):828-829.

Holbrook T.C. \& White S.L. 1992. Ancillary test for assessment of the nervous system. In: Wilson, J.H. (Ed), The Veterinary Clinics of North America Food Animal Practice: Physical examination. Vol.8. W.B. Saunders Company, Philadelphia. 433p.

Hübner S.O., Oliveira A.P., Franco A.C., Esteves P.A., Silva A.D., Spilki F.R., Rijsewijk F.A.M. \& Roehe P.M. 2005. Experimental infection of calves with a gI, gE, US9 negative bovine herpesvirus type 5. Comp. Immunol. Microbiol. Infect. Dis. 28:187-196.

Isernhagen A.J. 2005. Meningoencefalite herpética em bezerros: evolução clínica e diagnóstico. Dissertação de Mestrado em Ciência Animal, Universidade Estadual de Londrina, Londrina, PR, 79p.

Jain N.C. 1993. Essentials of veterinary hematology. Lea \& Febiger, Philadelphia. 417p. 
Jeffrey M., Duff J.P., Higgins R.J., Simpson V.R., Jackman R., Jones T.O., Mechie S.C. \& Liversey C.T. 1994. Polioencephalomalacia associated with the ingestion of ammonium sulphate by sheep and cattle.Vet. Rec. 134(14):343-348.

Jensen R., Griner L.A. \& Adams O.R. 1956. Polioencephalomalacia of cattle and sheep. J. Am. Vet. Med. Assoc. 129:311-321.

Johnston L.A.Y., Simmons G.C. \& McGavin M.D. 1962. Viral meningoencephalitis in calves. Austr. Vet. J. 38:207-215.

Klasing K.C., Goff J.P., Greger J.L. \& King J.C. 2005. Mineral tolerance of animals. 2nd rev.edn. The Nacional Academics Press, Washington DC, p.372-385.

Kul O., Karahan S., Basalan M. \& Kabakcl N. 2006. Polioencephalomalacia in cattle: a consequence of prolonged feeding barley malt sprouts. J. Vet. Med. A. 53(3):123-128.

Lemos R.A.A., Driemeier D., Guimarães E.B., Dutra I.S., Mori A.E. \& Barros C.S.L. 2004. Lead poisoning in cattle grazing pasture contaminated by industrial waste. Vet. Hum. Toxicol. 46(6):326-328.

Lemos R.A.A. \& Riet-Correa F. 2007. Polioencefalomalacia, p.658-670. In: Riet-Correa F., Schild A.L., Lemos R.A.A. \& Borges J.R.J. (Eds), Doenças de Ruminantes e Eqüídeos. Vol.2. $3^{\text {a }}$ ed. Pallotti, Santa Maria.

Lisbôa J.A.N, Isernhagen A.J., Borges A.S., Amorim R.M., Balarin M.R.S., Lunardi M. \& Alfieri A.A. 2009. Hematological and Cerebrospinal Fluid Changes in Cattle Naturally and Experimentally Infected with the Bovine Herpesvirus 5. Braz. Arch. Biol. Technol. 52:69-76.

Loneragan G.H., Gould D.H., Callan R.J., Sigurdson C.J. \& Hamar D.W. 1998. Association of excess sulfur intake and an increase in hydrogen sulfide concentrations in the ruminal gas cap of recently weaned beef calves with polioencephalomalacia. J. Am. Vet. Med. Assoc. 213:15991604.

Loneragan G.H., Wagner J.J., Gould D.H., Garry F.B. \& Thoren M.A. 2001. Effects of water sulfate concentrations on performance, water intake, and carcass characteristics of feedlot steers. J. Anim. Sci. 79(12):2941-2948.

Loneragan G.H., Gould D.H., Wagner J., Garry F. \& Thoren M. 2005. The magnitude and patterns of ruminal hydrogen sulfide production, blood thiamine concentration, and mean pulmonary arterial pressure in feedlot steers consuming water of different sulfate concentrations. The Bovine Practitioner 39(1):16-22. 
Lunardi M., Claus M.P., Lisboa J.A.N., Amude A.M., Headley S.A., Alfieri A.F. \& Alfieri A.A. 2009. Neurological and epidemiological aspects of a BoHV-5 meningoencephalitis outbreak. Braz. Arch. Biol. Technol. 52:77-85.

Mcallister M.M., Gould D.H. \& Raisbeck M.F. 1997. Evaluation of ruminal sulfide concentrations and seasonal outbreaks of polioencephalomalacia in beef cattle in a feedlot. J. Am. Vet. Med. Assoc. 211(10):1275-1279.

McKenzie R.A., Carmichael A.M., Schibrowski M.L., Duigan S.A., Gibson J.A. \& Taylor J.D. Sulfur-associated polioencephalomalacia in cattle grazing plants in the family Brassicaceae. Austr. Vet. J. 87(1,2):27-32.

Mayhew I.G. Large animal neurology: a handbook for veterinary clinics.1989. Lea \& Febiger, London. 379p.

Mendes L.C.N., Borges A.S., Peiró J.R., Feitosa F.L.F. \& Anhesini C.R. 2007. Estudo retrospectivo de 19 casos de polioencefalomalácia, em bovinos, responsivos ao tratamento com tiamina. Arq. Bras. Med. Vet. Zootec. 59(1):239-241.

Meyer G., Lemaire M., Ros C., Belak K., Gabriel A., Cassart D., Coignoul F., Belak S. \& Thiry E. 2001. Comparative pathogenesis of acute and latent infections of calves with bovine herpesvirus types 1 and 5. Arch. Virol. 146:633-652.

Moro L., Nogueira R.H.G., Carvalho A.U. \& Marques D.C. 1994. Relato de três casos de polioencefalomalacia em bovinos. Arq. Bras. Med. Vet. Zootec. 46(4):409-416.

Nakazato L., Lemos R.A.A. \& Riet-Correa F. 2000. Polioencefalomalacia em bovinos nos estados de Mato Grosso do Sul e São Paulo. Pesq. Vet. Bras. 20(3):119-125.

Niles G.A., Morgan S.E. \& Edwards W.C. 2000. Sulfur-induced polioencephalomalacia in stocker calves. Vet. Human Toxicol. 42(5):290- 291.

Niles G.A., Morgan S., Edwards W.C. \& Lalman D. 2002. Effects of dietary sulfur concentrations on the incidence and pathology of polioencephalomalacia in weaned beef calves. Vet. Human Toxicol. 44(2):70-72.

Osweiler G.D., Carr T.F., Sanderson T.P., Carson T.L. \& Kinker J.A. 1995. Water deprivationsodium ion toxicosis in cattle. J. Vet. Diagn. Invest. 7: 583-585. 
Perez S.E., Bretschneider G., Leunda M.R., Osorio E.A., Flores E.F. \& Odeon A.C. 2002. Primary infection, latency, and reactivation of bovine herpesvirus type 5 in bovine nervous system. Vet. Path. 39:437-444.

Perez S.E., Vagnozzi A., Sur J.H., Odriozola E., Campero C.M. \& Odeon A.C. 2003. Retrospective analysis of cases with a diagnosis of cerebrocortical necrosis and its relation with type 5 bovine herpesvírus. Rev. Arg. Microbiol. 35:69-73.

Pritchard D. \& Eggleston G.W. 1978. Nardoo fern and polioencephalomalacia. Austr. Vet. J. 54(4):204-205.

Radostits O.M., Gay C.C., Hinchcliff K.W. et al. (Eds). 2007. Veterinary medicine: A textbook of the diseases of cattle, horses, sheep, pigs, and goats. $10^{\mathrm{a}}$ ed. W.B. Saunders, Philadelphia. p.724725.

Riet-Correa F., Vidor T., Schild A.L. \& Méndez M.C. 1989. Meningoencefalite e necrose do córtex cerebral em bovinos por herpesvírus bovino-1. Pesq. Vet. Bras. 9:13-16.

Raisbeck M. F. 1982. Is polioencephalomalacia associated with high-sulfate diets? J. Am. Vet. Med. Assoc. 180(11):1303-1305.

Reed R.H. \& Muench H. 1938. A single method of estimating fifty percent end points. Am. J. Hyg. 27:493-497.

Riet-Correa G., Duarte M.D., Barbosa J.D., Oliveira C.M.C., Cerqueira V.D., Brito M.F. \& RietCorrea F. 2006. Meningoencefalite e polioencefalomalacia causada por Herpesvírus bovino-5 no Estado do Pará. Pesq. Vet. Bras. 26:44-46.

Rissi D.R., Oliveira F.N., Rech R.R., Pierezan F., Lemos R.A.A. \& Barros C.S.L. 2006. Epidemiologia, sinais clínicos e distribuição das lesões encefálicas em bovinos afetados por meningoencefalite por herpesvírus bovino-5. Pesq. Vet. Bras. 26:123-132.

Rissi D.R., Rech R.R., Flores E.F., Kommers G.D. \& Barros C.S.L. 2007. Meningoencefalite por meningoencefalite por herpesvírus bovino-5. Pesq. Vet. Bras. 27:251-260.

Rissi D.R., Pierezan F., Silva M.S., Flores E.F. \& Barros C.S.L. 2008. Neurological disease in cattle in southern Brazil associated with Bovine herpesvirus infection. J. Vet. Diagn. Invest. 20:346349.

Sager R.L., Hamar D.W. \& Gould D.H. 1990. Clinical and biochemical alterations in calves with nutritionally induced polioencephalomalacia. Am. J. Vet. Res. 51(12):1969-1974. 
Salvador S.W.C., Lemos R.A.A., Riet-Correa F., Roehe P.M. \& Osório A.L.A.R. 1998. Meningoencefalite em bovinos causada por herpesvírus bovino-5 no Mato Grosso do Sul e São Paulo. Pesq. Vet. Bras. 18:76-83.

Sampaio I.B.M. 1998. Estatística Aplicada à Experimentação Animal. UFMG, Belo Horizonte. $221 \mathrm{p}$.

Sanches A.W.D., Langohr I.M., Stigger A.L. \& Barros C.S.L. 2000. Doenças do sistema nervoso central em bovinos no Sul do Brasil. Pesq. Vet. Bras. 20:113-118.

Sant'ana F.J.F., Rissi D.R., Lucena R.B., Lemos R.AA, Nogueira A.P.A. \& Barros C.S.L. 2009a. Polioencefalomalacia em bovinos: epidemiologia, sinais clínicos e distribuição das lesões no encéfalo. Pesq Vet. Bras. 297(7):487-497.

Sant'ana F.J.F., Lemos R.AA, Nogueira A.P.A., Togni M., Tessele B. \& Barros C.S.L. 2009b. Polioencefalomalacia em ruminantes. Pesq. Vet. Bras. 29(9):681-694.

Santos M.N., Jardim Filho J.O. \& Grando F.A. 1983. Polioencefalomálacia em bovinos no Rio Grande do Sul. Pesq. Vet. Bras. 3:37-39.

Scott P.R. 1995. The collection and analysis of cerebrospinal fluid: an aid to diagnosis in ruminant neurological diseases. British Vet. J. 151:603-614.

Scott P.R. 2004. Diagnostic techniques and clinicpathologic findings in ruminant neurological disease. Vet. Clin. North Am. Food Anim. Pract. 20:215-230.

Silva A.M., Weiblen R., Irigoyen L.F., Roehe P.M., Sur H.J., Osório F.A. \& Flores E.F. 1998. Experimental infection of sheep with bovine herpesvirus typt-5: acute and latent infection. Vet. Microbiol. 66:89-99.

Silva M.S., Brum M.C.S., Weiblen R. \& Flores E.F. 2007. Identificação e diferenciação de herpesvírus bovino tipos 1 e 5 isolados de amostras clínicas no Centro-sul do Brasil, Argentina e Uruguai (1987-2006). Pesq. Vet. Bras. 27:403-408.

Souza V.F., Melo S.V., Esteves P.A., Schmidt C.S., Gonçalves D.A., Schaefer R., Silva T.C., Almeida R.S., Vicentini F., Franco A.C., Oliveira E.A., Spilki F.R., Weiblen R., Flores E.F., Lemos R.A., Alfieri A.A., Pituco E.M. \& Roehe P.M. 2002. Caracterização de herpesvírus bovinos tipos 1 (BHV-1) e 5 (BHV-5) com anticorpos monoclonais. Pesq. Vet. Bras. 22:13-18.

Stevens J.G. 1994. Overview of herpesvirus latency. Sem. Virol. 5:191-196. 
Stöber M. 1993. Sistema nervoso central. In: Rosemberg, G. (Ed), Exame Clínico dos Bovinos. Guanabara Koogan, Rio de Janeiro. 421p.

Stokol T., Divers T.J., Arrigan J.W. \& McDonough S.P. 2009. Cerebrospinal fluid findings in cattle with central nervous system disorders: a retrospective study of 102 cases (1990-2008). Vet. Clin. Pat. 38(1):103-112.

Summers B.A., Cummings J. \& De Lahunta A. 1995. Veterinary Neuropathology. Mosby, St. Louis. 527 p.

Traverso S.D., Colodel E.M., Loretti A.P., Seitz A.L., Correa A.M., Krauspenhar C. \& Driemeier D. 2001. Polioencefalomalacia em bovinos leiteiros no Rio Grande do Sul suplementados com enxofre. $10^{\circ}$ ENAPAVE, Pirassununga, SP, p.72. (Resumo).

Traverso S.D., Loretti A.P., Donini M.A. \& Driemeier D. 2004. Lead poisoning in cattle in southern Brazil. Arq. Bras. Med. Vet. Zootec. 56(3):418-421.

Trueman K.F. \& Clague D.C. 1978. Sodium chloride poisoning in cattle.Aust. Vet. J. 54(2):89-91.

Tvedten H.W. 1987. Clinical pathology of bovine neurologic disease, p.24-44. In: Baker, J. D. (Ed), Bovine Neurological Diseases. The Veterinary Clinics of North America: Food Animal Practice. Vol.3. W.B. Saunders, Philadelphia.

Van Soest P.J. 1994. Nutritional ecology of the ruminant. Cornell University Press, Cornell. 485p.

Vogel F.S.F., Caron L., Flores E.F., Weiblen R., Winkelmann E.R., Mayer S.V. \& Bastos R.G. 2003. Distribution of bovine herpesvirus type 5 DNA in the central nervous system of latently, experimentally infected calves. J. Clin. Microbiol. 41:4512-4520.

Vogel F.S.F., Lima M., Flores E.F., Weiblen R., Winkelmann E.R., Mayer S.V., Mazzutti K.C. \& Arenhart S. 2004. Replicação e excreção viral durante a infecção aguda e após a reativação da latência induzida por dexametasona em bezerros inoculados com os herpesvírus bovinos tipo 1 (BHV-1) e 5 (BHV-5). Ciência Rural 34:1619-1621.

Weiblen R., Barros C.S.L., Canabarro T.F. \& Flores E.F. 1989. Bovine meningoencephalitis from IBR virus. Vet. Rec. 124:666-667. 
Quadro 1. Valores médios e desvios-padrão $(\bar{x} \pm \sigma)$ da temperatura retal $\left({ }^{\circ} \mathrm{C}\right)$, frequência cardíaca (batimentos/min) e respiratória (movimentos/min) e motricidade ruminal (movimentos/cinco min) aferidos durante período de 30 dias nos seis bezerros mestiços após infecção experimental com o herpesvirus bovino 5 (BoHV-5).

\begin{tabular}{|c|c|c|c|c|}
\hline Dias & $\begin{array}{l}\text { Temperatura } \\
\text { retal }\end{array}$ & $\begin{array}{l}\text { Frequência } \\
\text { Cardíaca }\end{array}$ & $\begin{array}{l}\text { Frequência } \\
\text { respiratória }\end{array}$ & $\begin{array}{c}\text { Motricidade } \\
\text { ruminal }\end{array}$ \\
\hline 1 & $38,75 \pm 0,79 a$ & $73,83 \pm 11,10 \mathrm{a}$ & $33,66 \pm 7,42 \mathrm{a}$ & $8,5 \pm 0,83 a$ \\
\hline 2 & $39,4 \pm 0,49 \mathrm{a}$ & $81,66 \pm 10,30 \mathrm{a}$ & $43,33 \pm 20,60 \mathrm{~b}$ & $8,33 \pm 1,03 \mathrm{a}$ \\
\hline 3 & $38,75 \pm 0,81 \mathrm{a}$ & $63,16 \pm 12,37 \mathrm{a}$ & $21,5 \pm 4,08 \mathrm{a}$ & $7,5 \pm 0,83 \mathrm{a}$ \\
\hline 4 & $39,65 \pm 0,63 a$ & $70,66 \pm 12,37 \mathrm{a}$ & $25,16 \pm 4,30 \mathrm{a}$ & $8 \pm 0,89 \mathrm{a}$ \\
\hline 5 & $39,81 \pm 0,29 a$ & $68 \pm 8,48 \mathrm{a}$ & $25,66 \pm 3,93 a$ & $7,66 \pm 0,51 \mathrm{a}$ \\
\hline 6 & $39,78 \pm 0,36 \mathrm{a}$ & $69,33 \pm 7,86 a$ & $28,83 \pm 7,96 a$ & $8,33 \pm 0,81 \mathrm{a}$ \\
\hline 7 & $39,96 \pm 0,36 a$ & $74 \pm 12,58 \mathrm{a}$ & $23 \pm 4,69 b$ & $8,33 \pm 1,03 \mathrm{a}$ \\
\hline 8 & $38,85 \pm 1,0 \mathrm{a}$ & $78 \pm 13,56 a$ & $26,33 \pm 4,63 a$ & $7,66 \pm 0,81 \mathrm{a}$ \\
\hline 9 & $40,06 \pm 0,36 b$ & $79 \pm 12,58 \mathrm{a}$ & $29,5 \pm 10,27 \mathrm{a}$ & $8,16 \pm 0,75 \mathrm{a}$ \\
\hline 10 & $39,73 \pm 0,47 \mathrm{a}$ & $73,83 \pm 10,24 a$ & $28,5 \pm 8,66 \mathrm{a}$ & $7,66 \pm 0,81 \mathrm{a}$ \\
\hline 11 & $39,51 \pm 0,46 \mathrm{a}$ & $71,66 \pm 6,05 a$ & $25,33 \pm 6,65 a$ & $8 \pm 0,89 \mathrm{a}$ \\
\hline 12 & $39,46 \pm 1,02 a$ & $69,2 \pm 6,05 \mathrm{a}$ & $33,8 \pm 12,49 \mathrm{a}$ & $7,6 \pm 0,54 \mathrm{a}$ \\
\hline 13 & $39,18 \pm 0,34 \mathrm{a}$ & $76,2 \pm 13,89 \mathrm{a}$ & $23,8 \pm 5,84 \mathrm{~b}$ & $8,2 \pm 1,09 \mathrm{a}$ \\
\hline 14 & $39 \pm 1,25 \mathrm{a}$ & $71,4 \pm 10,28 \mathrm{a}$ & $27,2 \pm 3,34 a$ & $8,6 \pm 0,89 \mathrm{a}$ \\
\hline 15 & $39,4 \pm 0,60 \mathrm{a}$ & $60,8 \pm 7,15 \mathrm{a}$ & $22,4 \pm 3,84 b$ & $8,2 \pm 0,44 \mathrm{a}$ \\
\hline 16 & $39,56 \pm 0,21 \mathrm{a}$ & $72,2 \pm 11,32 \mathrm{a}$ & $27 \pm 8,48 \mathrm{a}$ & $8,2 \pm 0,44 \mathrm{a}$ \\
\hline 17 & $39,34 \pm 0,27 \mathrm{a}$ & $65,6 \pm 3,57 a$ & $41,2 \pm 11,96 \mathrm{a}$ & $7,8 \pm 0,83 \mathrm{a}$ \\
\hline 18 & $39,26 \pm 0,43 a$ & $72,8 \pm 8,67 \mathrm{a}$ & $29,6 \pm 12,44 \mathrm{a}$ & $8 \pm 0,70 \mathrm{a}$ \\
\hline 19 & $39,16 \pm 0,57 \mathrm{a}$ & $72,6 \pm 5,17 \mathrm{a}$ & $27,2 \pm 9,54 \mathrm{a}$ & $8 \pm 0,54 \mathrm{a}$ \\
\hline 20 & $39,42 \pm 0,54 \mathrm{a}$ & $66,8 \pm 17,06 \mathrm{a}$ & $31,2 \pm 5,93 \mathrm{a}$ & $8,4 \pm 0,54 \mathrm{a}$ \\
\hline 21 & $39,42 \pm 0,88 \mathrm{a}$ & $69,2 \pm 5,93 \mathrm{a}$ & $29 \pm 5,38 \mathrm{a}$ & $8,4 \pm 0,54 \mathrm{a}$ \\
\hline 22 & $39,4 \pm 0,74 \mathrm{a}$ & $58,75 \pm 6,39 \mathrm{a}$ & $28,25 \pm 2,87 \mathrm{a}$ & $8 \pm 0,81 \mathrm{a}$ \\
\hline 23 & $39,35 \pm 0,64 a$ & $69,25 \pm 20,15 \mathrm{a}$ & $28,75 \pm 10,17 \mathrm{a}$ & $8,25 \pm 0,97 \mathrm{a}$ \\
\hline 24 & $39,62 \pm 0,53 a$ & $70,25 \pm 12,28 \mathrm{a}$ & $31,25 \pm 8,77 \mathrm{a}$ & $8 \pm 0,81 \mathrm{a}$ \\
\hline 25 & $38,52 \pm 0,75 b$ & $62,25 \pm 10,78 \mathrm{a}$ & $27,25 \pm 3,59 a$ & $8 \pm 1,41 \mathrm{a}$ \\
\hline 26 & $39,05 \pm 0,23 a$ & $71,75 \pm 14,61 \mathrm{a}$ & $25,75 \pm 5,31 \mathrm{a}$ & $9 \pm 0,81 \mathrm{a}$ \\
\hline 27 & $38,25 \pm 1,36 a$ & $68 \pm 13,56 a$ & $22,5 \pm 5 \mathrm{a}$ & $8,25 \pm 0,95 \mathrm{a}$ \\
\hline 28 & $38,72 \pm 0,85 \mathrm{a}$ & $64 \pm 6,97 \mathrm{a}$ & $25,5 \pm 3 \mathrm{a}$ & $8,25 \pm 0,5 \mathrm{a}$ \\
\hline 29 & $38,87 \pm 1,0 \mathrm{a}$ & $67,5 \pm 14,24 \mathrm{a}$ & $31,5 \pm 8,69 a$ & $7,75 \pm 0,5 \mathrm{a}$ \\
\hline 30 & $38,72 \pm 0,43 a$ & $61,5 \pm 10,08 a$ & $27,25 \pm 4,27 \mathrm{a}$ & $7,75 \pm 0,95 \mathrm{a}$ \\
\hline
\end{tabular}

Letras minúsculas diferentes nas colunas indicam diferença significativa $(\mathrm{p}<0,05)$ entre os momentos avaliados. 
Quadro 2. Valores médios e desvios-padrão $(\bar{x} \pm \sigma)$ do eritrograma avaliados antes da inoculação (M0) e no $5^{\circ}$ dia p.i. (M1), $9^{\circ}$ dia p.i. (M2), $14^{\circ}$ dia p.i. (M3), $19^{\circ}$ dia p.i (M4), $21^{\circ}$ dia p.i (M5), $26^{\circ}$ dia p.i (M6) e $30^{\circ}$ dia p.i (M7) dos bezerros mestiços após infecção experimental com o herpesvírus bovino 5 (BoHV-5).

\begin{tabular}{|c|c|c|c|c|c|}
\hline Momentos & $\begin{array}{l}\text { Hemácias } \\
\left(\mathbf{x 1 0} / \mathbf{m m}^{3}\right)\end{array}$ & $\begin{array}{l}\text { Hemoglobina } \\
\text { (g/DI) }\end{array}$ & $\begin{array}{c}\begin{array}{c}\text { Volume } \\
\text { globular } \\
(\%)\end{array} \\
\end{array}$ & $\begin{array}{c}\text { VGM } \\
\text { (Fl) }\end{array}$ & $\begin{array}{c}\text { CHGM } \\
(\%)\end{array}$ \\
\hline M0 & $6,76 \pm 0,55 a$ & $10,38 \pm 0,70 \mathrm{a}$ & $31,33 \pm 3,50 \mathrm{a}$ & $4 \overline{6,52 \pm 5,53 a}$ & $33,32 \pm 2,5 \mathrm{a}$ \\
\hline M1 & $5,76 \pm 0,57 \mathrm{a}$ & $8,25 \pm 0,53 b$ & $25,33 \pm 2,42 b$ & $44,01 \pm 2,3 \mathrm{a}$ & $32,64 \pm 1,13 a$ \\
\hline M2 & $5,86 \pm 0,52 a$ & $8,71 \pm 0,69 b$ & $26 \pm 1,78 b$ & $44,39 \pm 2,01 \mathrm{a}$ & $33,55 \pm 2,05 \mathrm{a}$ \\
\hline M3 & $5,68 \pm 0,64 a$ & $8,81 \pm 1,07 \mathrm{~b}$ & $26,33 \pm 2,94 b$ & $46,39 \pm 3,13 \mathrm{a}$ & $33,46 \pm 1,19 a$ \\
\hline M4 & $6,0 \pm 0,67 \mathrm{a}$ & $9,04 \pm 0,86 b$ & $25,8 \pm 2,04 \mathrm{~b}$ & $43,09 \pm 1,82 \mathrm{a}$ & $35,00 \pm 0,65 \mathrm{a}$ \\
\hline M5 & $5,94 \pm 1,07 \mathrm{a}$ & $9,57 \pm 1,21 b$ & $27,75 \pm 3,30 \mathrm{~b}$ & $47,20 \pm 5,77 \mathrm{a}$ & $34,51 \pm 1,57 \mathrm{a}$ \\
\hline M6 & $6,17 \pm 1,17 \mathrm{a}$ & $10,1 \pm 1,28 b$ & $29 \pm 3,74 b$ & $47,43 \pm 4,05 \mathrm{a}$ & $33,32 \pm 2,5 \mathrm{a}$ \\
\hline M7 & $6,30 \pm 1,20 \mathrm{a}$ & $9,65 \pm 1,61 b$ & $29,25 \pm 4,11 \mathrm{~b}$ & $46,52 \pm 5,53 a$ & $32,64 \pm 1,13 a$ \\
\hline
\end{tabular}

Letras minúsculas diferentes nas colunas indicam diferença significativa $(\mathrm{p}<0,05)$ entre os momentos avaliados. 
Quadro 3. Valores médios e desvios-padrão $(\bar{x} \pm \sigma)$ do leucograma avaliados antes da inoculação (M0) e no $5^{\circ}$ dia p.i. (M1), $9^{\circ}$ dia p.i. (M2), $14^{\circ}$ dia p.i. (M3), $19^{\circ}$ dia p.i (M4), $21^{\circ}$ dia p.i (M5), $26^{\circ}$ dia p.i (M6) e $30^{\circ}$ dia p.i (M7) dos bezerros mestiços após infecção experimental com o herpesvírus bovino 5 (BoHV-5).

\begin{tabular}{|c|c|c|c|c|c|}
\hline Momentos & $\begin{array}{l}\text { Leucócitos } \\
\left(\times 10^{3} / \mathrm{mm}^{3}\right)\end{array}$ & $\begin{array}{c}\text { Segmentados } \\
\left(\mathbf{x} 10^{3} / \mathbf{m m}^{3}\right)\end{array}$ & $\begin{array}{l}\text { Linfócitos } \\
\left(\times 10^{3} / \mathrm{mm}^{3}\right)\end{array}$ & $\begin{array}{l}\text { Eosinófilos } \\
\left(\mathbf{x 1 0} / \mathbf{m m}^{3}\right)\end{array}$ & $\begin{array}{l}\text { Monócitos } \\
\left(\times 10^{3} / \mathbf{m m}^{3}\right)\end{array}$ \\
\hline M0 & $8,1 \pm 2,03 \mathrm{a}$ & $1,89 \pm 0,44 \mathrm{a}$ & $5,94 \pm 1,72 \mathrm{a}$ & $0,25 \pm 0,18$ & $0,08 \pm 0,02$ \\
\hline M1 & $8,4 \pm 2,05 \mathrm{a}$ & $2,14 \pm 0,99 \mathrm{a}$ & $6,12 \pm 1,45 \mathrm{a}$ & $0,15 \pm 0,11$ & 0,09 \\
\hline M2 & $6,98 \pm 1,83 \mathrm{a}$ & $1,65 \pm 1,20 \mathrm{a}$ & $5,28 \pm 0,89 a$ & 0,06 & 0,09 \\
\hline M3 & $8,05 \pm 2,82 \mathrm{a}$ & $2,56 \pm 1,87 \mathrm{a}$ & $5,43 \pm 1,01 \mathrm{a}$ & $0,08 \pm 0,003$ & $0,053 \pm 0,01$ \\
\hline M4 & $6,66 \pm 1,40 \mathrm{a}$ & $1,67 \pm 0,50 \mathrm{a}$ & $4,86 \pm 1,21 \mathrm{a}$ & $0,22 \pm 0,006$ & 0,15 \\
\hline M5 & $8,25 \pm 3,48 \mathrm{a}$ & $2,5 \pm 1,98 \mathrm{a}$ & $5,47 \pm 1,38 \mathrm{a}$ & $0,29 \pm 0,02$ & 0,14 \\
\hline M6 & $6,3 \pm 1,14 \mathrm{a}$ & $1,31 \pm 0,53 a$ & $4,88 \pm 0,64 \mathrm{a}$ & $0,13 \pm 0,05$ & 0 \\
\hline M7 & $5,52 \pm 0,84 \mathrm{a}$ & $1,17 \pm 0,27 \mathrm{a}$ & $4,39 \pm 0,88 \mathrm{a}$ & $0,05 \pm 0,009$ & 0,05 \\
\hline
\end{tabular}

Letras minúsculas diferentes nas colunas indicam diferença significativa $(\mathrm{p}<0,05)$ entre os momentos avaliados. 


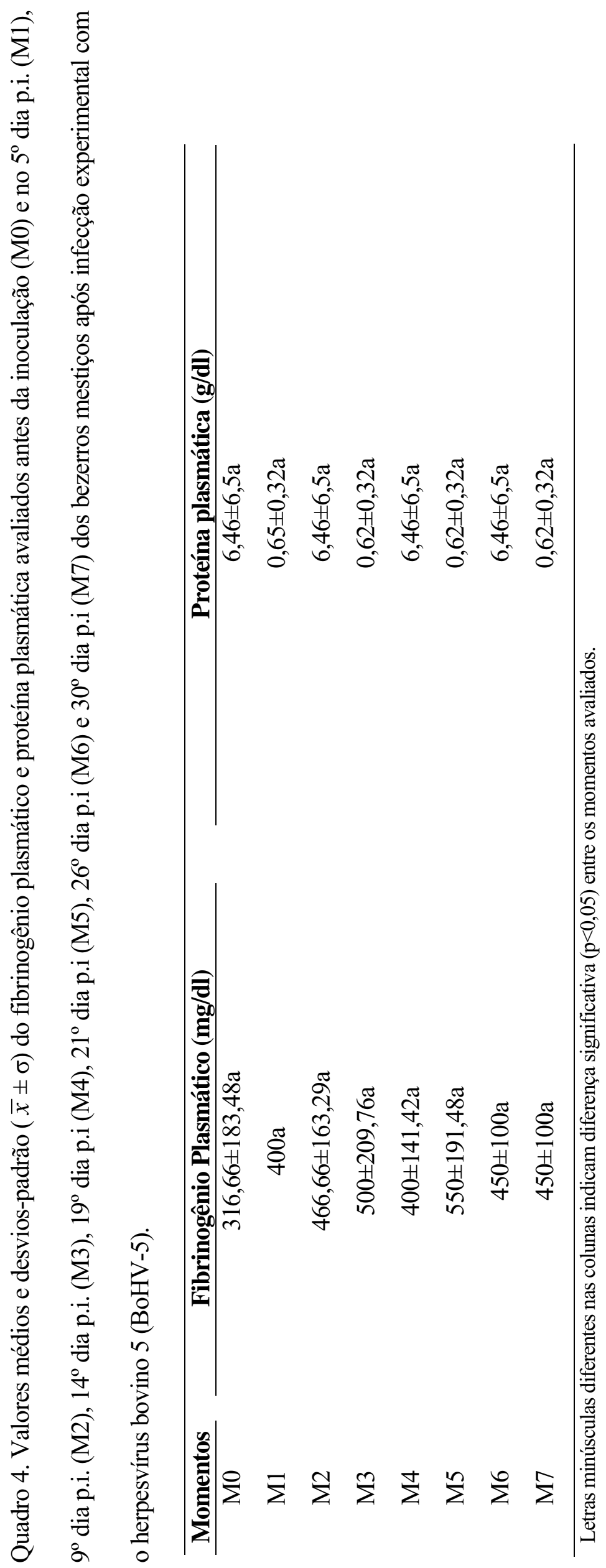


$\begin{array}{lll}\circ & 107 & 107\end{array}$

孚

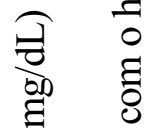

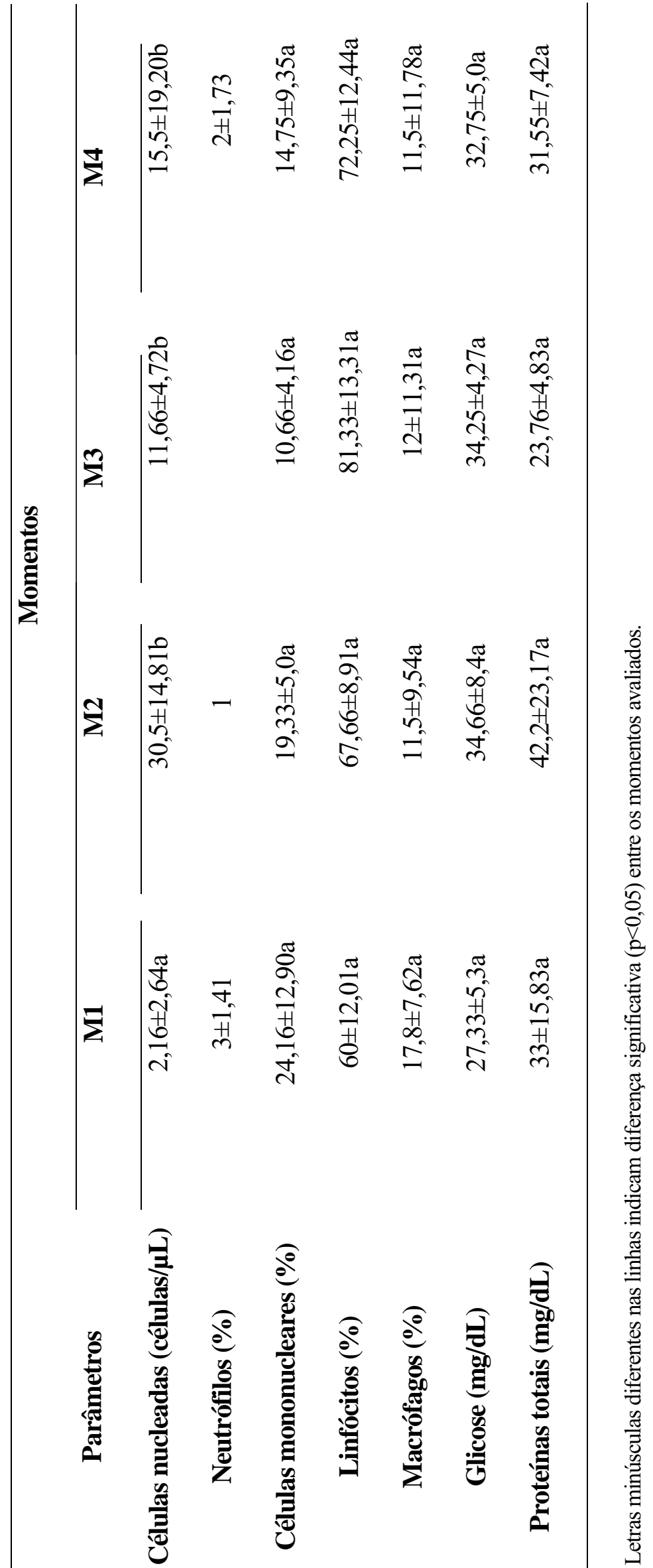




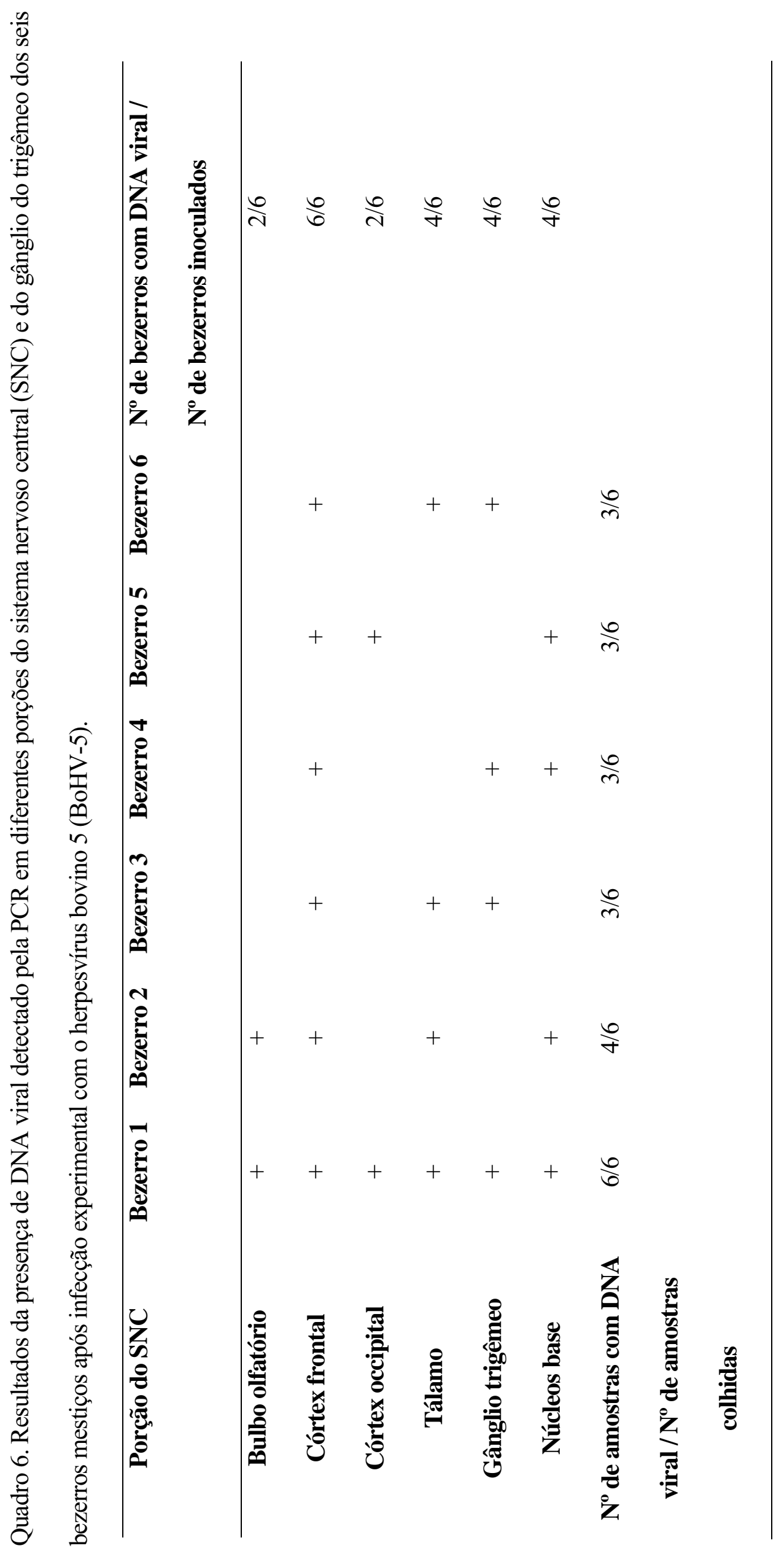




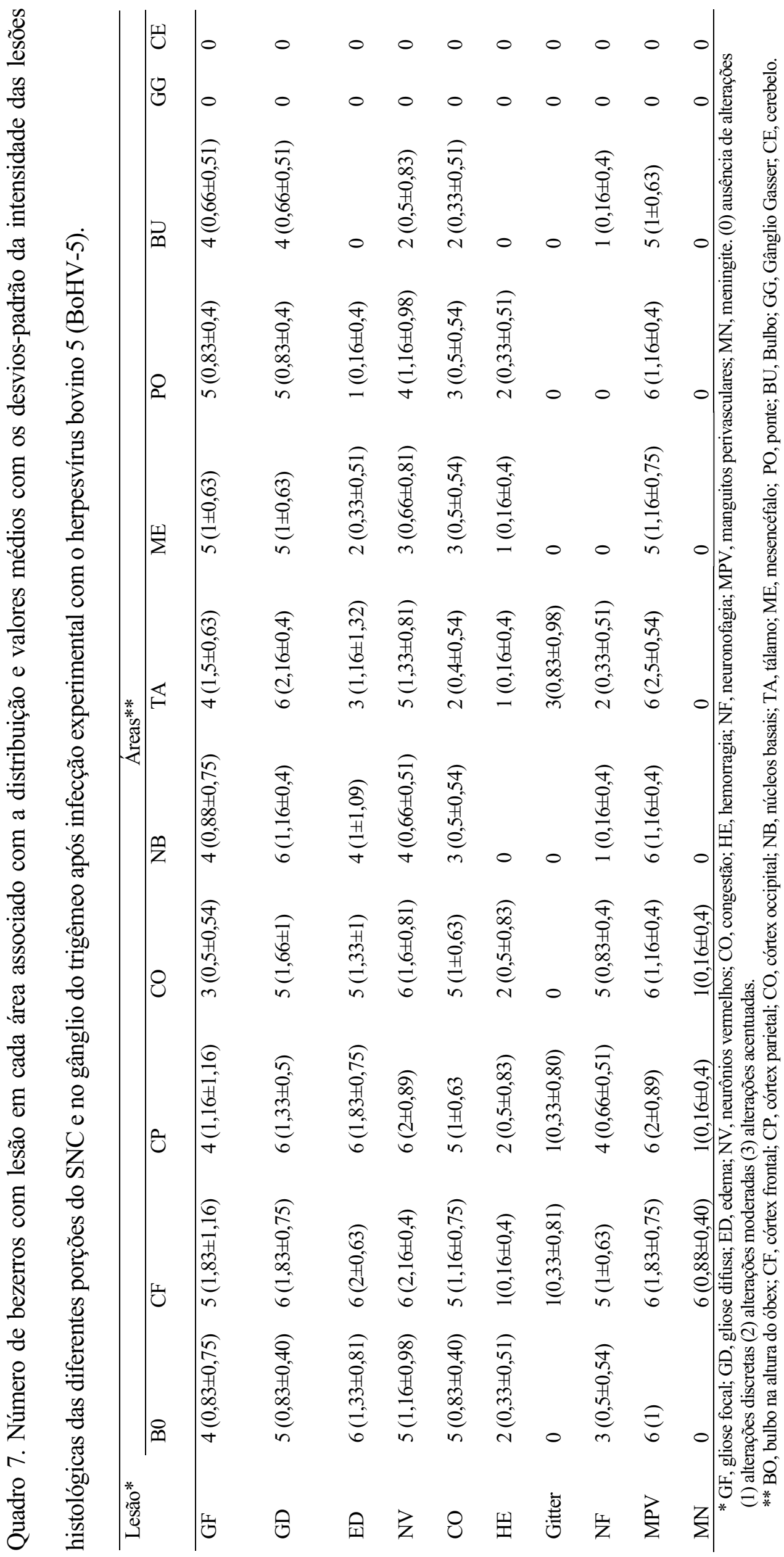




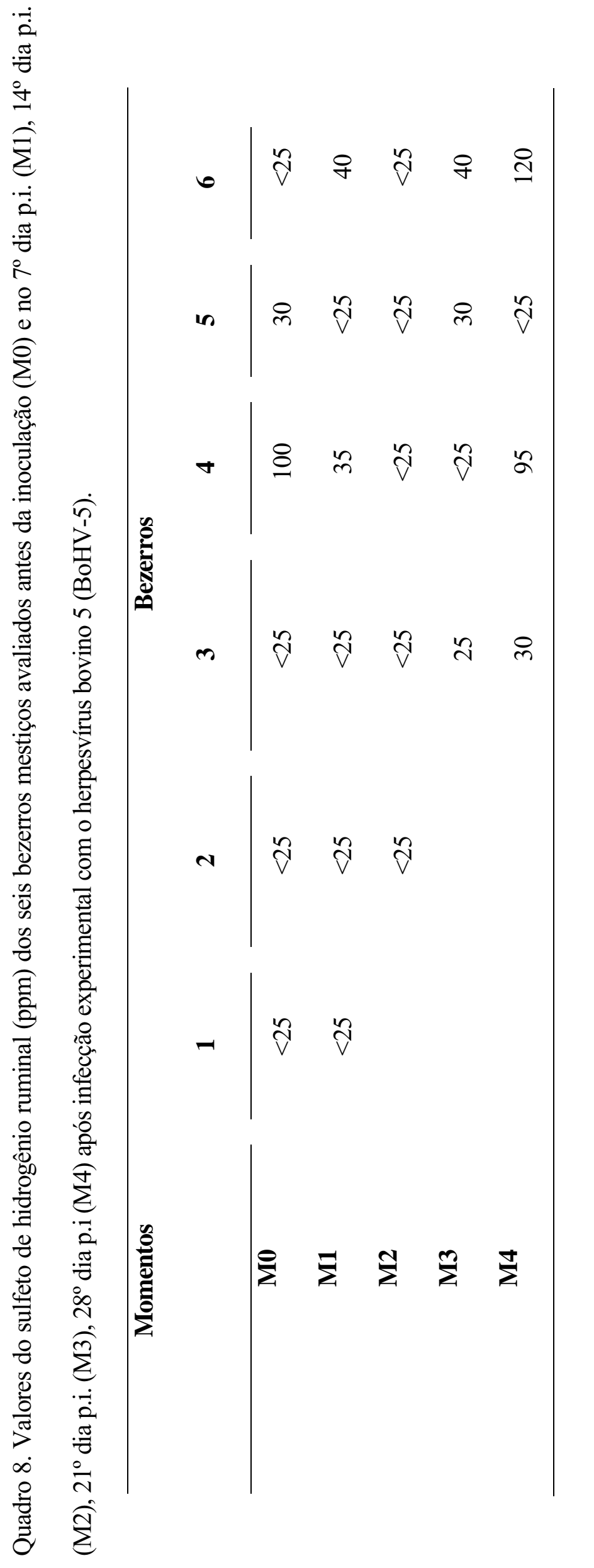




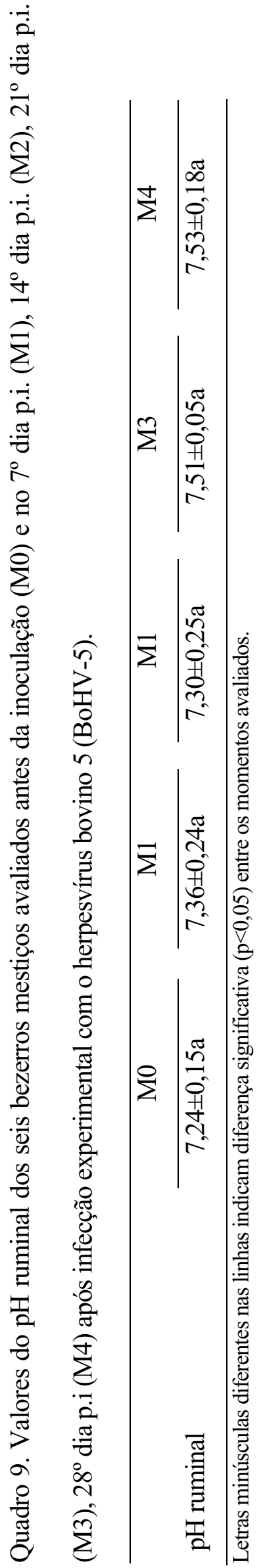




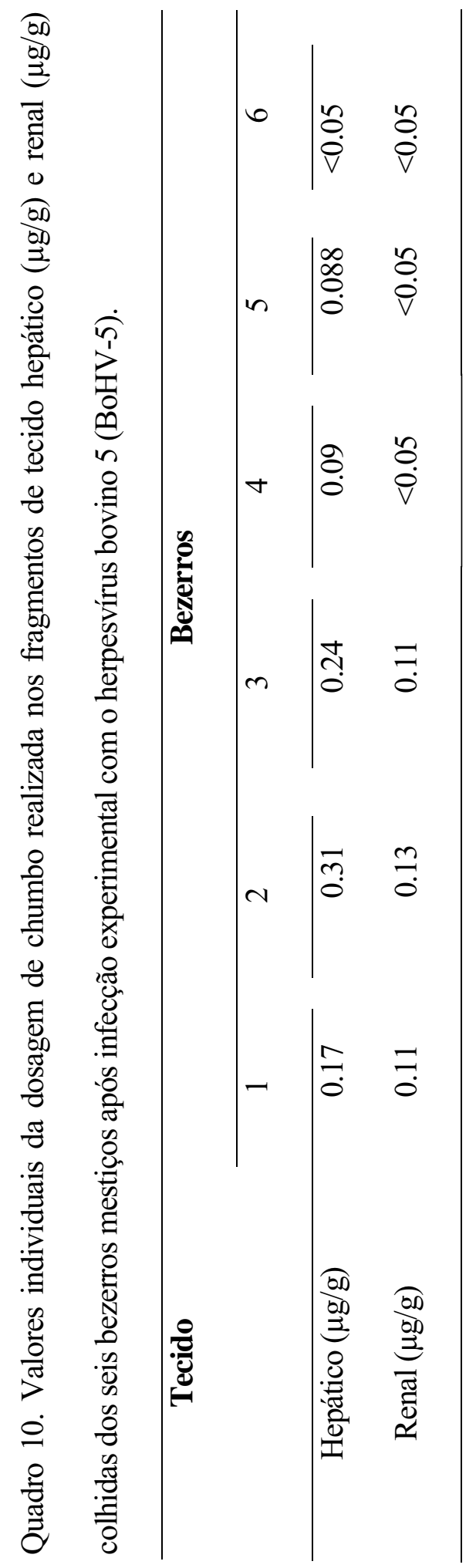




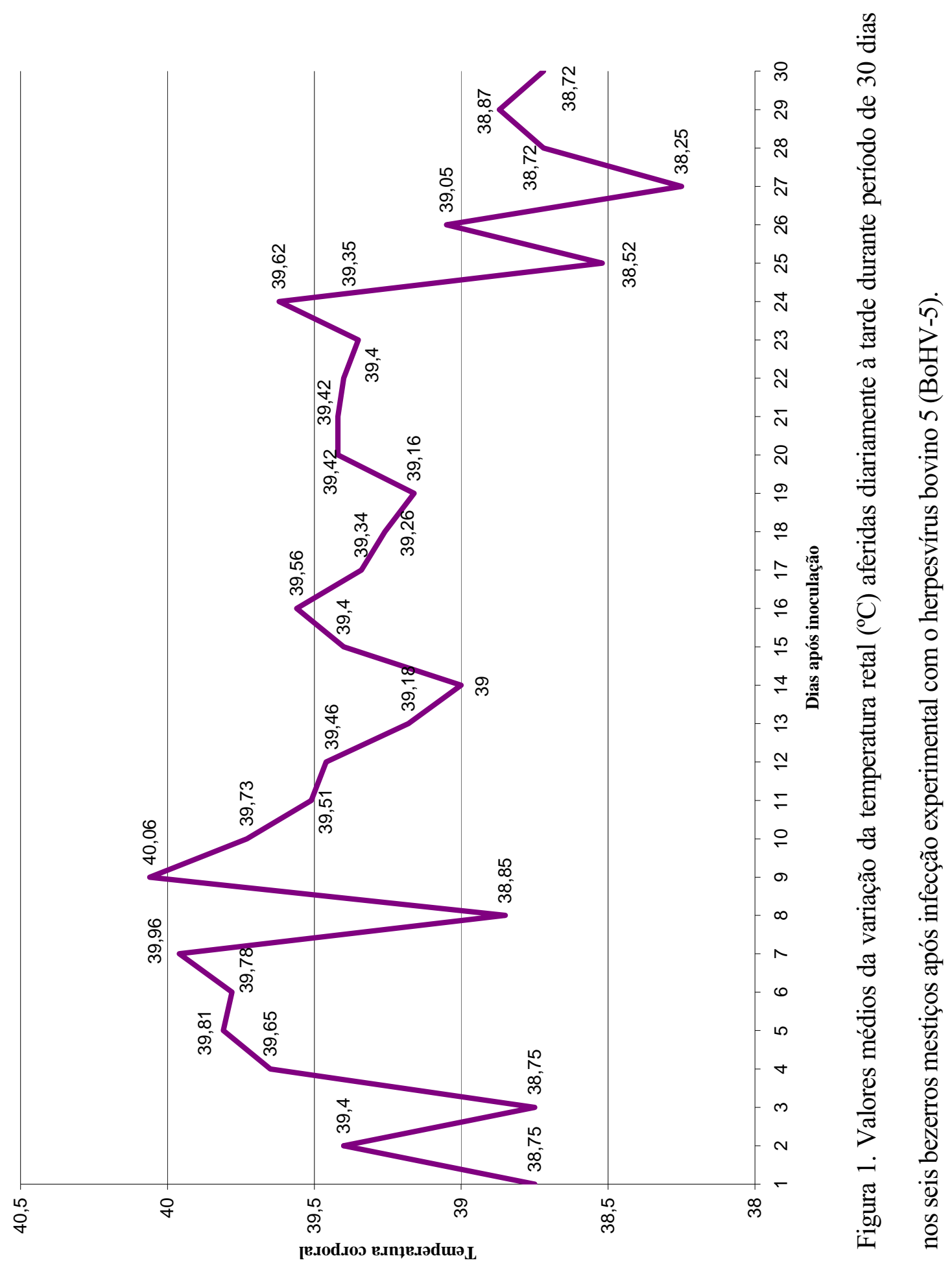




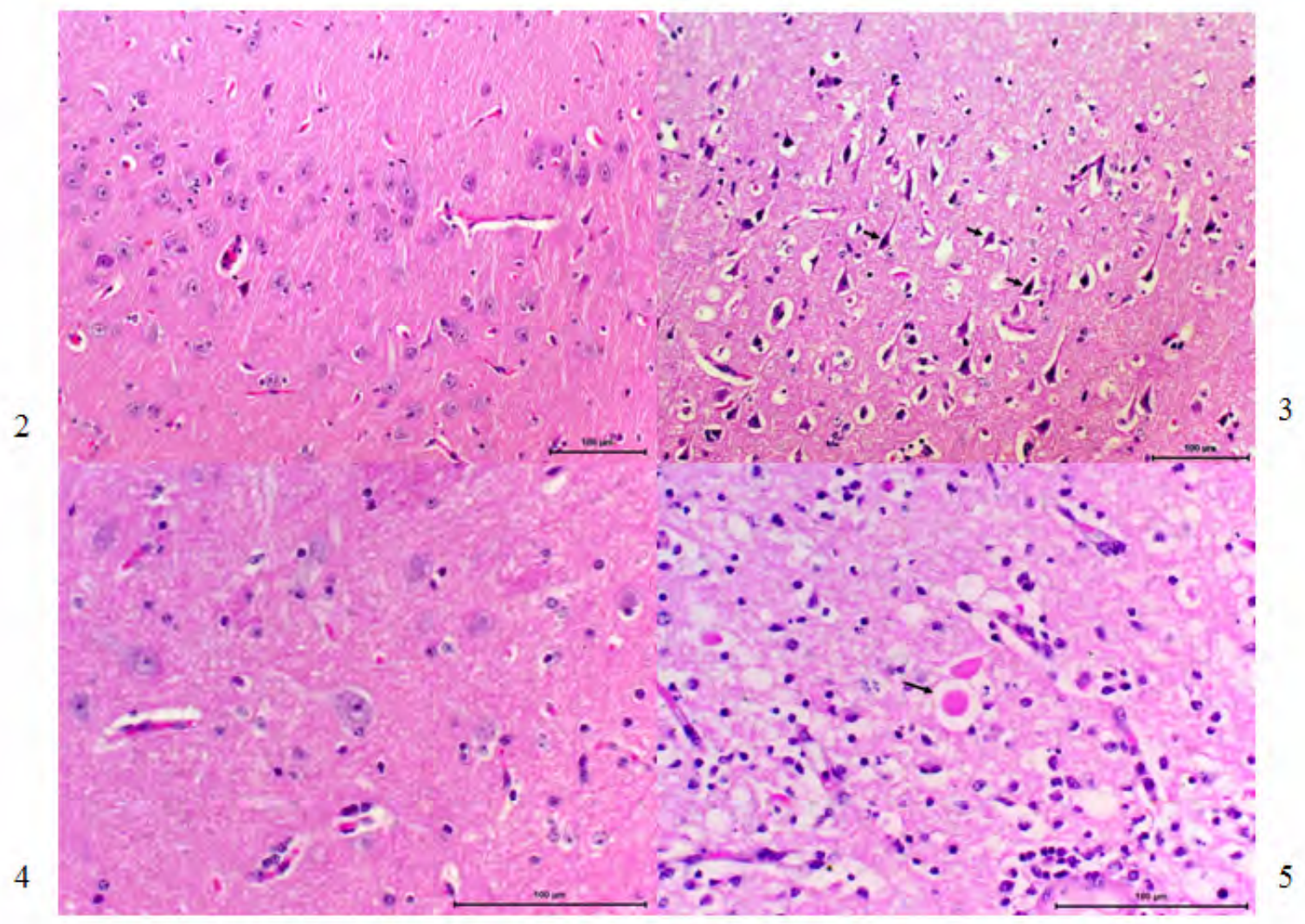

Figura 2. Bezerro controle. Córtex frontal. Os neurônios do córtex telencefálico possuem núcleos grandes, vesiculosos, nucléolo evidente e citoplasma levemente basofilico. HE, obj. 20x.

Figura 3. Bezerro 1. Córtex frontal. Os neurônios do córtex telencefálico apresentam núcleos picnóticos e citoplasma acidofilico encolhido (setas) e o edema de neurópilo. $\mathrm{HE}$, obj. $20 \mathrm{x}$.

Figura 4. Bezerro controle. Tálamo. Os neurônios do tálamo apresentam núcleos grandes e vesiculosos, nucléolo evidente e citoplasma levemente basofilico. HE, obj. $40 \mathrm{x}$.

Figura 5. Bezerro 1. Tálamo. Infiltrado inflamatório mononuclear difuso, acentuado, associado a edema e degeneração axonal (seta). HE, obj. 40x. 


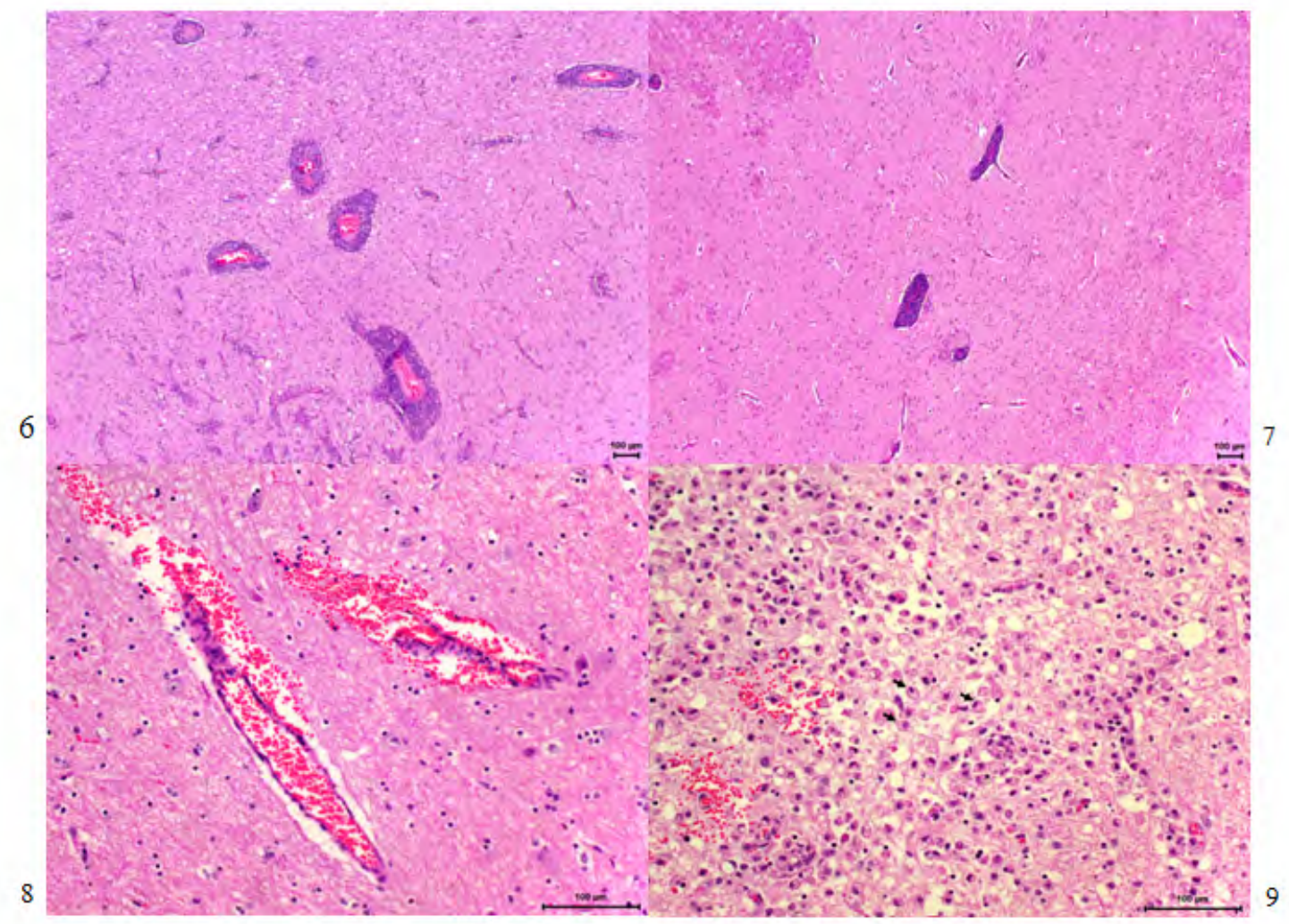

Figura 6. Bezerro 3. Córtex frontal. Presença de manguitos perivasculares compostos por células mononucleares. HE, obj. $2,5 \mathrm{x}$.

Figura 7. Bezerro 4. Núcleos da base. Presença de manguitos perivasculares compostos por células mononucleares. $\mathrm{HE}$, obj. $2,5 \mathrm{x}$.

Figura 8. Bezerro 2. Tálamo. Áreas de hemorragia perivascular. HE, obj. 20x.

Figura 9. Bezerro 2. Tálamo. Área focal de malacia com presença de inúmeras células Gitter (setas) e hemorragia. HE, obj. $20 \mathrm{x}$. 


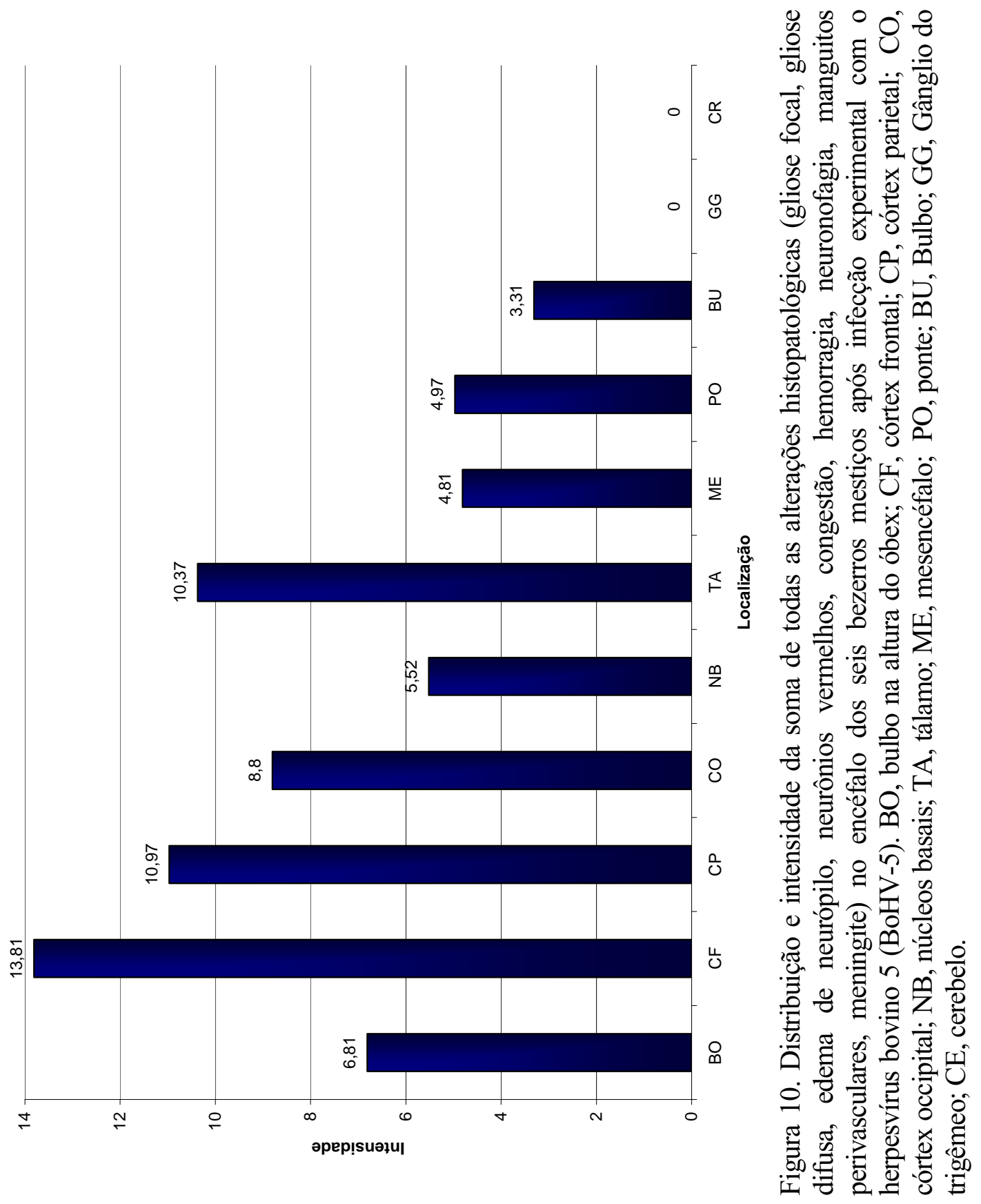


CONCLUSÕES GERAIS 


\section{CONCLUSÕES GERAIS}

Os resultados obtidos a partir dos dois experimentos realizados nos permitiu concluir que a ingestão de uma dieta com $0,52 \%$ de enxofre na matéria seca e a inoculação com BoHV-5 causaram PEM nos bezerros.

Os dois protocolos experimentais acarretaram distúrbios neurológicos em apenas um animal de cada modelo analisado, não sendo possível diferenciar estes dois agentes causadores da PEM apenas pelos sinais de encefalopatias observados. Isto enfatiza a importância da utilização de exames auxiliares para o estabelecimento do diagnóstico diferencial, tais como, a dosagem de sulfeto de hidrogênio ruminal utilizando tubos colorimétricos nos animais que ingeriram dieta com alto teor de enxofre e a análise do LCR nos animais com encefalite ocasionada pelo BoHV-5. Além disso, notou-se que a técnica da PCR foi eficaz para detecção do DNA viral do BoHV-5 no LCR do bezerro no momento que apresentou sinais neurológicos.

Os principais achados histopatológicos identificados nos bezerros que ingeriram ração com alto teor de enxofre associado com dieta rica em carboidrato de alta fermentação e baixa quantidade de fibra efetiva foram necrose neuronal cortical e lesões hemorrágicas nos núcleos basais, tálamo, mesencéfalo, ponte e bulbo.

Na indução de PEM em bezerros pela inoculação experimental com o BoHV-5, as alterações histopatológicas caracterizadas por necrose cerebrocortical, encefalite e meningite não supurativa, variaram em intensidade e foram mais acentuadas no córtex frontal e parietal. 
REFERENACIAS (CAPÍTULOI) 


\section{REFERENCIAS (CAPITULO I)}

AFIP 2005/2006. Case III. 5th Wednesday Slide Conference, Conference, Armed Forces Institute of Pathology. Disponível em http://vp4.afip.org/wsc/wsc05/05wsc05.pdf.

Alegre M., Nanni M. \& Fondevila N. 2001. Development of a multiplex polymerase chain reaction for the differentiation of bovine herpesvirus-1 and 5. J. Vet. Med. 48:613-621.

Ashbaugh S.E., Thompson K.E., Belknap E.B., Schultheiss P.C., Chowdhury S. \& Collins J.K. 1997. Specific detection of shedding and latency of bovine herpesvirus 1 and 5 using a nested polymerase chain reaction. J. Vet. Diag. Invest. 9:387-394.

Barros C.S.L., Driemeier D., Dutra I.S. \& Lemos R.A.A. 2006. Doenças do Sistema Nervoso de Bovinos no Brasil. Agnes, São Paulo, p.166-171.

Beauchamp R.O., Jr. Bus, J.S. \& Popp J. A. 1984. A critical review of the literature on hydrogen sulfide toxicity. Crit. Rev. Toxicol. 13:25-97.

Burgess B.A. Polioencephalomalacia. 2008. Large Anim. Vet. 8(8): 1-6.

Buttrey S.A., Allen V.G., Fontenot J.P. \& Reneau R.B. 1986. Effect of sulfur fertilization on chemical composition, ensiling characteristics and utilization of corn silage by lambs. J. Anim. Sci. 63:1236.

Cebra C.K. \& Cebra M.L. 2004. Altered mentation caused by polioencephalomalacia, hypernatremia, and lead poisoning. Vet. Clin. North Am. Food Anim. Pract. 20(2): 287-302.

Christian, R.G. \& Tryphonas L. 1971. Lead poisoning in cattle. Brain lesions and hematologic changes. Am. J. Vet. Res. 32:203.

Claus M.P., Alfieri A.F. \& Alfieri A.A. 2002. Herpesvírus Bovino tipo 5 e Meningoencefalite herpética bovina. Semina 23(1): 131-141.

Claus M.P., Alfieri A.F., Folgueras-Flatschart A.V., Wosiacki S.R., Medici K.C. \& Alfieri A.A. 2005. Rapid detection and differentiation of bovine herpesvírus 1 and 5 glycoprotein C gene in clinical specimens by multiplex-PCR. J. Virol. Meth. 128:183-188. 
Claus M.P., Alfieri A.F., Médici K.C., Lunardi M. \& Alfieri A.A. 2007. Bovine herpesvirus 5 detection by virus isolation in cell culture and Multiplex-PCR in central nervous system from cattle with neurological disease in Brazilian herds. Braz. J. Microbiol. 38:485-490.

Coghlin, C.L. Hydrogen sulphide poisoning in cattle. 1944. Can. J. Comparative Med. 8(4):111-113.

Colodel E.M., Nakazato L., Weiblen R., Mello R.M., Silva R.R.P., Souza M.A., Filho J.A.O. \& Caron L. 2002. Meningoencefalite necrosante em bovinos causada por herpesvírus bovino no estado de Mato Groso do Sul, Brasil. Ciência Rural 32:293-298.

Coppock R.W., Wagner W.C., Reynolds J.D., Vogel R.S., Gelberg H.B., Florence L.Z. \& Wolff W.A. 1991. Evaluation of edetate and thiamine for treatment of experimentally induced environmental lead poisoning in cattle. Am. J. Vet. Res. 52:1860-1865.

Cummings B.A., Gould D.H., Caldwell D.R. \& Hamar.D.W. 1995. Ruminal microbial alterations associated with sulfide generation in steers with dietary sulfate-induced polioencephalomalacia. Am. J. Vet. Res. 56:1390-1395.

Cunha P.H.J., Badial P.R., Oliveira Filho J.P., Amorim R.L., Cagnini D.Q. \& Borges A.S. Intoxicação experimental por enxofre em bovinos Nelore. In: $2^{\circ}$ Encontro Nacional de Diagnóstico Veterinário, 2008, Campo Grande - MS. Anais do $2^{\circ}$ ENDIVET, 2008. p. 20-21. (Cd-room).

Cunha P.H.J., Badial P.R., Oliveira Filho J.P., Cagnini Q.D., Marinheiro M.F., Gorino A.C. \& Borges A.S. 2009. Avaliação da concentração do sulfeto de hidrogênio ruminal utilizando tubos colorimétricos em bovinos criados extensivamente. Anais do $8^{\circ}$ Congresso Brasileiro de Buiatria. Belo Horizonte, BH. Ciên. Anim. Bras. (Supl. 1) 83-87.

Davies E.T. 1965. Cerebrocortical necrosis in calves. Vet. Rec. 77:290.

D’Angelo A., Miniscalco B., Bellino C., Bormida S., Borrelli A., Maurella C., Riondato F., Biolatti C. \& Cagnasso A. 2009.Analysis of cerebrospinal fluid from 20 calves after storage for 24 hours. Vet. Rec. 18(164):491- 493.

Del Médico Zajac M.P., Ladelfa M.F., Kotsias F., Muylkens B., Thiry J., Thiry E. \& Romera S.A. 2009. Biology of bovine herpesvirus 5. Vet. J. doi:10.1016/j.tvj1.2009.03.035. (in press). 
Dewhurst R.J., Kim E.J., Evans R.T., Cabrita A.R.J. \& Fonseca A.J.M. 2007. Effects of dietary sulphur sources on concentrations of hydrogen sulphide in the rumen headspace gas of dairy cows. Animal 1(4): 531-535.

Dey S., Swarup D. \& Singh B. 1995. Treatment of lead toxicity in calves. Vet. Hum. Toxicol. 37:230.

Dickie C.W., Nelson R.J., Frazee D.G., Krugman L.D. \& Bronner E. 1979. Polioencephalomalacia in range cattle. J. Am. Vet. Med. Assoc. 175:460

d'Offay J.M., Ely R.W., Baldwin C.A., Whitenack D.L., Stair E.L. \& Collins J.K. 1995. Diagnosis of encephalitic bovine herpesvirus type 5 (BHV-5) infection in cattle: virus isolation and immunohistochemical detection of antigen in formalin-fixed bovine brain tissues. J. Vet. Diag. Invest. 7:247-251.

De Paula R.R., Souza M.A., Colodel E.M., Hübner S.O., Brum K.B., Jorge K.B.C. \& Damasceno A.D. 2005. Meningoencefalite causada pelo BHV-5 em um bovino no Estado de Goiás. Arq. Bras. Med. Vet. Zoot. 57 (Supl.1):2.

Edwin E.E. \& Jackman R. 1973. Ruminal thiaminase and tissue thiamine in cerebrocortical necrosis. Vet. Rec. 92:640-641.

Edwin E.E. \& Jackman, R. 1981. Nature of the autofluorescent material in cerebrocortical necrosis. J. Neurochem. 37(4):1054-1056.

Elias F., Schild A.L. \& Riet-Correa F. 2004. Meningoencefalite e encefalomalácia por herpesvírus bovino-5: distribuição das lesões no sistema nervoso central de bovinos naturalmente infectados. Pesq. Vet. Bras. 24:123-131.

Gonçalves R.C., Viana L., Sequeira J.L., Bandarra E.P., Chiacchio S.B. \& Kuchembuck M.R.G. 2001. Aspectos clínicos, anatomopatológicos e epidemiológicos da polioencefalomalácia em bovinos, na região de Botucatu, SP. Vet. Not. 7(2): 54-57.

Gooneratne S.R., Olkowski A.A., Klemmer R.G., Kessler G.A. \& Christensen D. A. 1989. High sulfur related thiamine deficiency in cattle: a field study. Can. Vet. J. 30(2):139-146.

Gould D.H. 2000. Update on sulphur-related polioencephalomalacia. Vet. Clin. North Am. Food Anim. Pract. 16(3):481-496. 
Gould D.H., Cummings B.A. \& Hamar D.W. 1997. In vivo indicators of pathologic ruminal sulfide production in steers with diet-induced polioencephalomalacia. J. Vet. Diag. Invest. 9(1):72-76.

Gould D.H., Mcallister M.M., Savage J.C. \& Hamar D.W. 1991. High sulfide concentrations in rumen fluid associated with nutritionally induced polioencephalomalacia in calves. Am. J. Vet. Res. 52(7):1164-1169.

Gould, D.H. 1998. Polioencephalomalacia. J. Anim. Sci. 76(1): 309-314.

Gunn M.F., Baird J.D. \& Wilkie J.S.N. 1987. Accidental sulfur poisoning in a group of Holstein heifers. Can. Vet. J. 28(4):188-192.

Hamlen H., Clark E. \& Janzen E. 1993. Polioencephalomalacia in cattle consuming water with elevated sodium sulfate levels: A herd investigation. Can. Vet. J. 34(3): 153-158.

Hardt P.F., Ocumpaugh W.R. \& Greene L.W. 1991. Forage mineral concentration, animal performance, and mineral status of heifers grazing cereal pastures fertilized with sulfur. J. Anim. Sci. 69:2310-2320

Harris W.N. 1987. Polioencephalomalacia in feedlot cattle drinking water high in sodium sulfate. Can. Vet. J. 28:717.

Haydock D. 2003. Sulfur-induced polioencephalomalacia in a herd of rotation cattle. Can. Vet. J. 44(10):828-829.

Hill F.I. \& Ebbett P.C. 1997. Polioencephalomalacia in cattle in New Zealand fed chou moellier (Brassica oleracea). N. Z. Vet. J. 45:37-39.

Hübner S.O., Pescador C., Corbellini L.G., Driemeier D., Spilki F.R. \& Roehe P.M. 2005. Otimização da imunoistoquímica para detecção de herpesvírus bovino tipo 5 (BHV-5) em tecidos do sistema nervoso central fixados com formaldeído. Arq. Bras. Med. Vet. Zootec. 57:1-6.

Isernhagen A.J. 2005. Meningoencefalite herpética em bezerros: evolução clínica e diagnóstico. Dissertação de Mestrado em Ciência Animal, Universidade Estadual de Londrina, Londrina, PR, 79p.

Jeffrey M., Duff J.P., Higgins R.J., Simpson V.R., Jackman R., Jones T.O., Mechie S.C. \& Liversey C.T. 1994. Polioencephalomalacia associated with the ingestion of ammonium sulphate by sheep and cattle.Vet. Rec. 134(14):343-348. 
Jensen R., Griner L.A. \& Adams O.R. 1956. Polioencephalomalacia of cattle and sheep. J. Am. Vet. Med. Assoc. 129:311-321.

Kandylis, K. 1983. Transfer of plasma sulfate from blood to rumen. A review. J. Dairy Sci. 66:2263-2270.

Kandylis K. 1984. Toxicology of sulfur in ruminants: review. J. Dairy Sci. 67:2179-2187.

Klasing K.C., Goff J.P., Greger J.L. \& King J.C. 2005. Mineral tolerance of animals. 2nd rev.edn. The Nacional Academics Press, Washington DC, 372-385.

Kul O., Karahan S., Basalan M. \& Kabakcl N. 2006. Polioencephalomalacia in cattle: a consequence of prolonged feeding barley malt sprouts. J. Vet. Med. A. 53(3):123128.

Kung L., Bracht J.Y. \& Tavares J.Y. 2000. Effects of various compounds on in vitro ruminal fermentation and production of sulfide. Anim. Feed Sci. Technol. 84:69-81.

Kung L., Hession A.O. \& Bracht, J.P. 1998. Inhibition of sulfate reduction to sulfide by 9,10-Anthraquinone in vitro ruminal fermentations. J. Dairy Sci. 81: 2251-2256.

Kunrath C.F., Vogel F.S.F., Oldoni I., Flores E.F., Weiblen R., Dezengrini R., Torres F.D. \& Pan K.A. 2004. Soroneutralização e imunofluorescência utilizando anticorpos monoclonais no diagnóstico rápido de infecções pelo herpesvírus bovino tipos 1 e 5 (BHV-1 e BHV-5). Ciência Rural 34:1877-1883.

Lemos R.A.A., Driemeier D., Guimarães E.B., Dutra I.S., Mori A.E. \& Barros C.S.L. 2004. Lead poisoning in cattle grazing pasture contaminated by industrial waste. Vet. Hum. Toxicol. 46(6):326-328.

Lemos, R.A.A., Nakazato, L., Barros, C.S.L., Gattas, C.B.A. \& Bonilla, R. 1997. Meningoencefalite eosinofílica em bovinos no estado do Mato Grosso do Sul. Arq. Inst. Biol. 64 (Supl.1): 43

Lemos R.A.A. 2005. Enfermidades do sistema nervoso de bovinos de corte das regiões Centro-Oeste e Sudeste do Brasil. Tese de Doutorado, Universidade Estadual Paulista, Jaboticabal, SP. 150p.

Lima E.F., Riet-Correa F., Tabosa I.M., Dantas A.F.M., Medeiros J.M. \& Sucupira Júnior G. 2005. Polioencefalomalacia em caprinos e ovinos na região semi-árida do Nordeste do Brasil. Pesq. Vet. Bras. 25(1):9-14. 
Lisbôa J.A.N, Isernhagen A.J., Borges A.S., Amorim R.M., Balarin M.R.S., Lunardi M. \& Alfieri A.A. 2009. Hematological and Cerebrospinal Fluid Changes in Cattle Naturally and Experimentally Infected with the Bovine Herpesvirus 5. Braz. Arch. Biol. Technol. 52: 69-76.

Little P.B. 1978. Identity of fluorescence in polioencephalomalacia.Vet. Rec. 103(4):76.

Loew F.M., Radostits O.M. \& Dunlop R.H. 1969. Polioencephalomalacia (cerebrocortical necrosis). Can. Vet. J. 10:54-56.

Loew F.M., Dunlop R.H. \& Christian R.G. 1970. Biochemical aspects of an outbreak of bovine polioencephalomalacia. Can. Vet. J. 11:57-61.

Loew F.M. 1975. Nutrition and bovine neurologic disease. J. Am. Vet. Med. Assoc. 166:219-221.

Loneragan G.H., Gould D.H., Callan R.J., Sigurdson C.J. \& Hamar D.W. 1998. Association of excess sulfur intake and an increase in hydrogen sulfide concentrations in the ruminal gas cap of recently weaned beef calves with polioencephalomalacia. J. Am. Vet. Med. Assoc. 213:1599-1604.

Loneragan G.H., Gould D.H., Wagner J., Garry F. \& Thoren M. 2005. The magnitude and patterns of ruminal hydrogen sulfide production, blood thiamine concentration, and mean pulmonary arterial pressure in feedlot steers consuming water of different sulfate concentrations. The Bovine Practitioner 39(1):16-22.

Loneragan G.H., Wagner J.J., Gould D.H., Garry F.B. \& Thoren M.A. 2001. Effects of water sulfate concentrations on performance, water intake, and carcass characteristics of feedlot steers. J. Anim. Sci. 79(12): 2941-2948.

Lunardi M., Claus M.P., Lisboa J.A.N., Amude A.M., Headley S.A., Alfieri A.F. \& Alfieri A.A. 2009. Neurological and epidemiological aspects of a BoHV-5 meningoencephalitis outbreak. Braz. Arch. Biol. Technol. 52:77-85.

Mcallister M.M., Gould D.H. \& Raisbeck M.F. 1997. Evaluation of ruminal sulfide concentrations and seasonal outbreaks of polioencephalomalacia in beef cattle in a feedlot. J. Am. Vet. Med. Assoc. 211(10):1275-1279.

McKenzie R.A., Carmichael A.M., Schibrowski M.L., Duigan S.A., Gibson J.A. \& Taylor J.D. 2009. Sulfur-associated polioencephalomalacia in cattle grazing plants in the family Brassicaceae. Austr. Vet. J. 87(1,2): 27-32. 
Mella C.M., Perez-Oliva O. \& Loew F.M. 1976. Induction of bovine polioencephalomalacia with feeding system based on molasses and urea. Can. J. Comp. Med. 40(1):104-110.

Mendes L.C.N., Borges A.S., Peiró J.R., Feitosa F.L.F. \& Anhesini C.R. 2007. Estudo retrospectivo de 19 casos de polioencefalomalacia, em bovinos, responsivos ao tratamento com tiamina. Arq. Bras. Med. Vet. Zootec. 59(1):239-241.

Morgan K.T. 1974. Amprolium poisoning of preruminant lambs: An ultrastructural study of the cerebral malacia and the nature of the inflammatory response. J. Pathol. 112:229-236.

Moro L., Nogueira R.H.G., Carvalho A.U. \& Marques D.C. 1994. Relato de três casos de polioencefalomalacia em bovinos. Arq. Bras. Med. Vet. Zootec. 46(4):409-416.

Nakazato L., Lemos R.A.A. \& Riet-Correa F. 2000. Polioencefalomalacia em bovinos nos estados de Mato Grosso do Sul e São Paulo. Pesq. Vet. Bras. 20(3):119-125.

Niles G.A., Morgan S., Edwards W.C. \& Lalman D. 2002. Effects of dietary sulfur concentrations on the incidence and pathology of polioencephalomalacia in weaned beef calves. Vet. Human Toxicol. 44(2):70-72.

Niles G.A., Morgan S.E. \& Edwards W.C. 2000. Sulfur-induced polioencephalomalacia in stocker calves. Vet. Human Toxicol. 42(5):290- 291.

Olkowski A.A., Gooneratne S.R., Rousseaux C.G. \& Christensen D.A. 1992. Role of thiamine status in sulphur induced polioencephalomalacia in sheep. Res. Vet. Sci. 52:78-85.

Olkowski A.A. 1997. Neurotoxicity and secondary metabolic problems associated with low to moderate levels of exposure to excess dietary sulphur in ruminants: a review. Vet. Human Toxicol. 39:355-360.

Oldoni I., Weiblen R., Inkelmann M.A. \& Flores E.F. 2004. Production and characterization of monoclonal antibodies to a Brazilian bovine herpesvirus type 5 . Braz. J. Med. Biol. Res. 37:213-221.

Ordonez F.J. 2003. Caracterização imunoistoquímica da reação inflamatória no sistema nervoso central de bovinos naturalmente infectados com herpes vírus bovino tipo 5 (BoHV-5). Dissertação de Mestrado. Universidade Estadual Paulista, Jaboticabal, SP. 40p. 
Ortolani E.L. 2001. Sulphur deficiency in dairy calves reared on pasture of Brachiaria decumbens. Ciência Rural. 31(2):257-261.

Osweiler G.D., Carr T.F., Sanderson T.P., Carson T.L. \& Kinker J.A. 1995. Water deprivation-sodium ion toxicosis in cattle. J. Vet. Diagn. Invest. 7: 583-585.

Perez S.E., Vagnozzi A., Sur J.H., Odriozola E., Campero C.M. \& Odeon A.C. 2003. Retrospective analysis of cases with a diagnosis of cerebrocortical necrosis and its relation with type 5 bovine herpesvírus. Rev. Arg. Microbiol. 35:69-73.

Pritchard D. \& Eggleston G.W. 1978. Nardoo fern and polioencephalomalacia. Austr. Vet. J. 54:204-205.

Radostits O.M., Gay C.C., Hinchcliff K.W. et al. (Eds). 2007. Veterinary medicine: A textbook of the diseases of cattle, horses, sheep, pigs, and goats. $10^{\mathrm{a}}$ ed. W.B. Saunders, Philadelphia. p.724-725.

Raisbeck M. F. 1982. Is polioencephalomalacia associated with high-sulfate diets? J. Am. Vet. Med. Assoc. 180(11):1303-1305.

Riet-Correa G., Duarte M.D., Barbosa J.D., Oliveira C.M.C., Cerqueira V.D., Brito M.F. \& Riet-Correa F. 2006. Meningoencefalite e polioencefalomalacia causada por Herpesvírus bovino-5 no Estado do Pará. Pesq. Vet. Bras. 26:44-46.

Riet-Correa F., Rivero R., Dutra F., Lemos R.A.A. \& Easton C. 2007. Polioencephalomalacia. 35ª Jornadas Uruguayas de Buiatría, p.191-198.

Rissi D.R., Oliveira F.N., Rech R.R., Pierezan F., Lemos R.A.A. \& Barros C.S.L. 2006. Epidemiologia, sinais clínicos e distribuição das lesões encefálicas em bovinos afetados por meningoencefalite por herpesvírus bovino-5. Pesq. Vet. Bras. 26:123132.

Rissi D.R., Pierezan F., Silva M.S., Flores E.F. \& Barros C.S.L. 2008. Neurological disease in cattle in southern Brazil associated with Bovine herpesvirus infection. J. Vet. Diagn. Invest. 20:346-349.

Rissi D.R., Rech R.R., Flores E.F., Kommers G.D. \& Barros C.S.L. 2007. Meningoencefalite por meningoencefalite por herpesvírus bovino-5. Pesq. Vet. Bras. 27:251-260. 
Roehe P.M., Silva T.C., Nardi N.B., Oliveira L.G. \& Rosa J.C.A. 1997. Diferenciação entre o vírus da rinotraqueíte infecciosa bovina (BHV-1) e o herpesvírus da encefalite bovina (BHV-5) com anticorpos monoclonais. Pesq. Vet. Bras. 17:41-44.

Sager R.L., Hamar D.W. \& Gould D.H. 1990. Clinical and biochemical alterations in calves with nutritionally induced polioencephalomalacia. Am. J. Vet. Res. 51(12):1969-1974.

Salvador S.W.C., Lemos R.A.A., Riet-Correa F., Roehe P.M. \& Osório A.L.A.R. 1998. Meningoencefalite em bovinos causada por herpesvírus bovino-5 no Mato Grosso do Sul e São Paulo. Pesq. Vet. Bras. 18:76-83.

Sanches A.W.D., Langohr I.M., Stigger A.L. \& Barros C.S.L. 2000. Doenças do sistema nervoso central em bovinos no Sul do Brasil. Pesq. Vet. Bras. 20:113-118.

Sant'ana F.J.F., Lemos R.AA, Nogueira A.P.A., Togni M., Tessele B. \& Barros C.S.L. 2009b. Polioencefalomalacia em ruminantes. Pesq. Vet. Bras. 29(9):681-694.

Sant'ana F.J.F., Rissi D.R., Lucena R.B., Lemos R.AA, Nogueira A.P.A. \& Barros C.S.L. 2009a. Polioencefalomalacia em bovinos: epidemiologia, sinais clínicos e distribuição das lesões no encéfalo. Pesq Vet. Bras. 297(7):487-497.

Santos M.N., Jardim Filho J.O. \& Grando F.A. 1983. Polioencefalomálacia em bovinos no Rio Grande do Sul. Pesq. Vet. Bras. 3:37-39.

Shibahara T., Horino R., Taniguchi T. \& Ando, Y. 1999. Autofluorescent substance and neurocyte necrosis in thiamine deficiency in cattle. Aust. Vet. J. 77:329-330.

Shreeve J.E. \& Edwin E.E. 1974.Thiaminase producing strains of Clostridium sporogenes associated with outbreaks of cerebrocortical necrosis. Vet. Rec. 94: 330.

Spears J.W., Burns J.C., \& Hatch PA. 1985. Sulfur fertilization of cool season grasses and effect on utilization of minerals, nitrogen, and fiber by steers. J. Dairy Sci. $68: 347$.

Sousa R.S. \& Irigoyen L.F. 1999. Intoxicação experimental por Phalaris angusta (Gramineae) em bovinos. Pesq. Vet. Bras. 19(3,4):116-122.

Souza V.F., Melo S.V., Esteves P.A., Schmidt C.S., Gonçalves D.A., Schaefer R., Silva T.C., Almeida R.S., Vicentini F., Franco A.C., Oliveira E.A., Spilki F.R., Weiblen R., Flores E.F., Lemos R.A., Alfieri A.A., Pituco E.M. \& Roehe P.M. 2002. 
Caracterização de herpesvírus bovinos tipos 1 (BHV-1) e 5 (BHV-5) com anticorpos monoclonais. Pesq. Vet. Bras. 22:13-18.

Traverso S.D., Colodel E.M., Loretti A.P., Seitz A.L., Correa A.M., Krauspenhar C. \& Driemeier D. 2001. Polioencefalomalacia em bovinos leiteiros no Rio Grande do Sul suplementados com enxofre. $10^{\circ}$ ENAPAVE, Pirassununga, p.72. (Resumo).

Traverso S.D., Loretti A.P., Donini M.A. \& Driemeier D. 2004. Lead poisoning in cattle in southern Brazil. Arq. Bras. Med. Vet. Zootec. 56(3):418-421.

Trueman K.F. \& Clague D.C. 1978. Sodium chloride poisoning in cattle. Aust. Vet. J. 54:89-91.

Weston, R.H., Lindsay J.R., Purser D.B., Gordon G.L.R. \& Davis P. 1988. Feed intake and digestion responses in sheep to the addition of inorganic sulfur to a herbage diet of low sulfur content. Aust. J. Agr. Res. 39(6):1107-1119. 
ANEXOS 


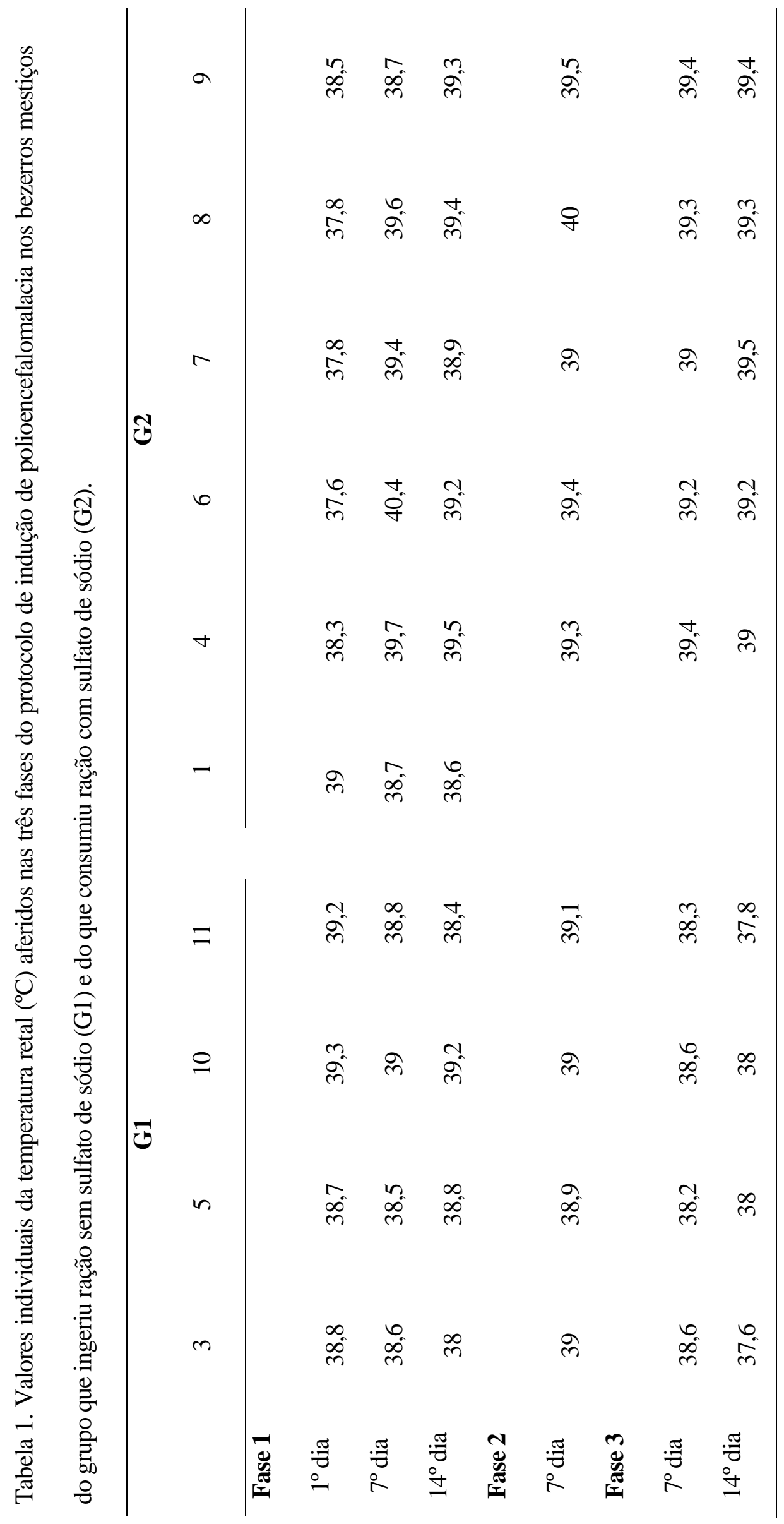




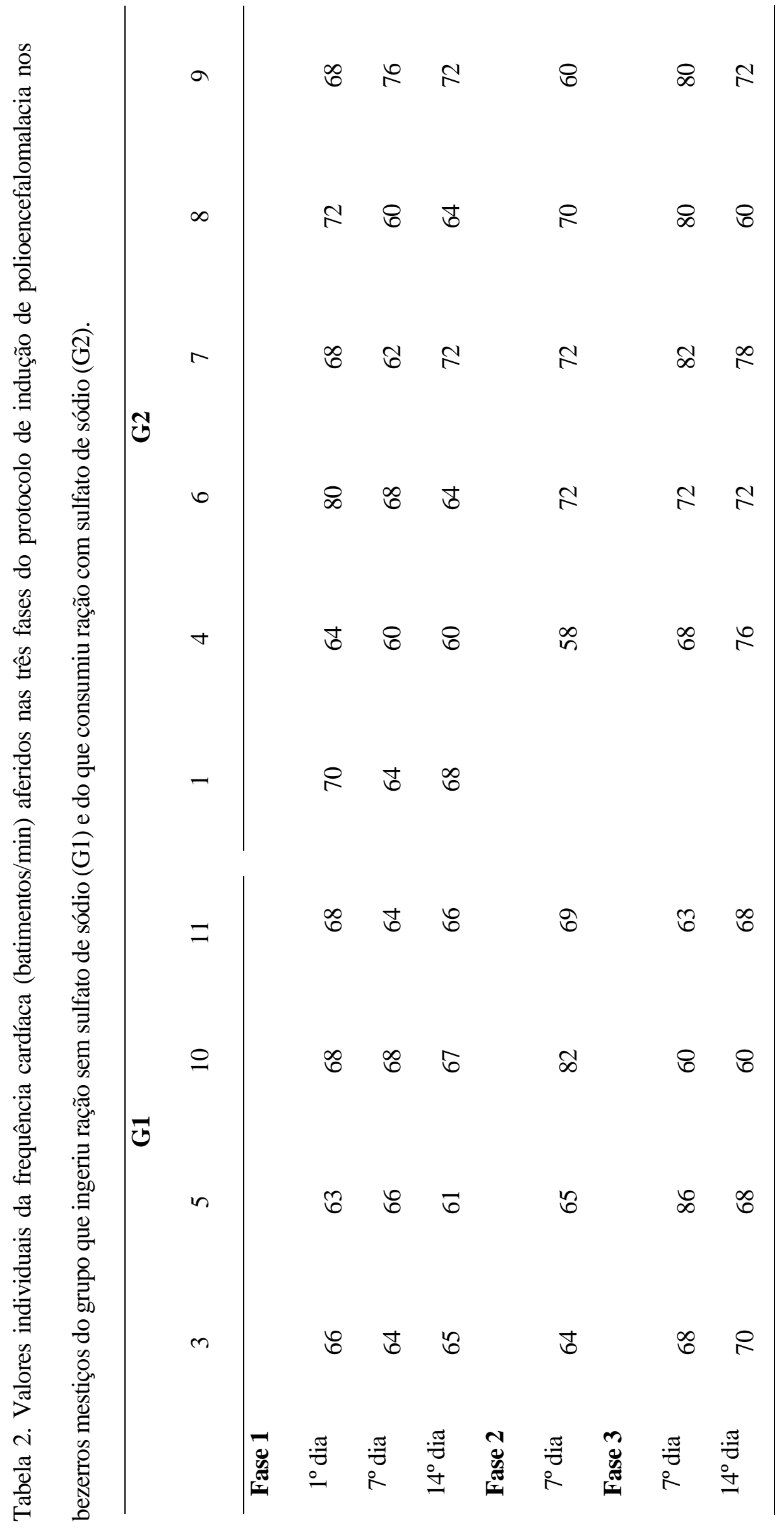




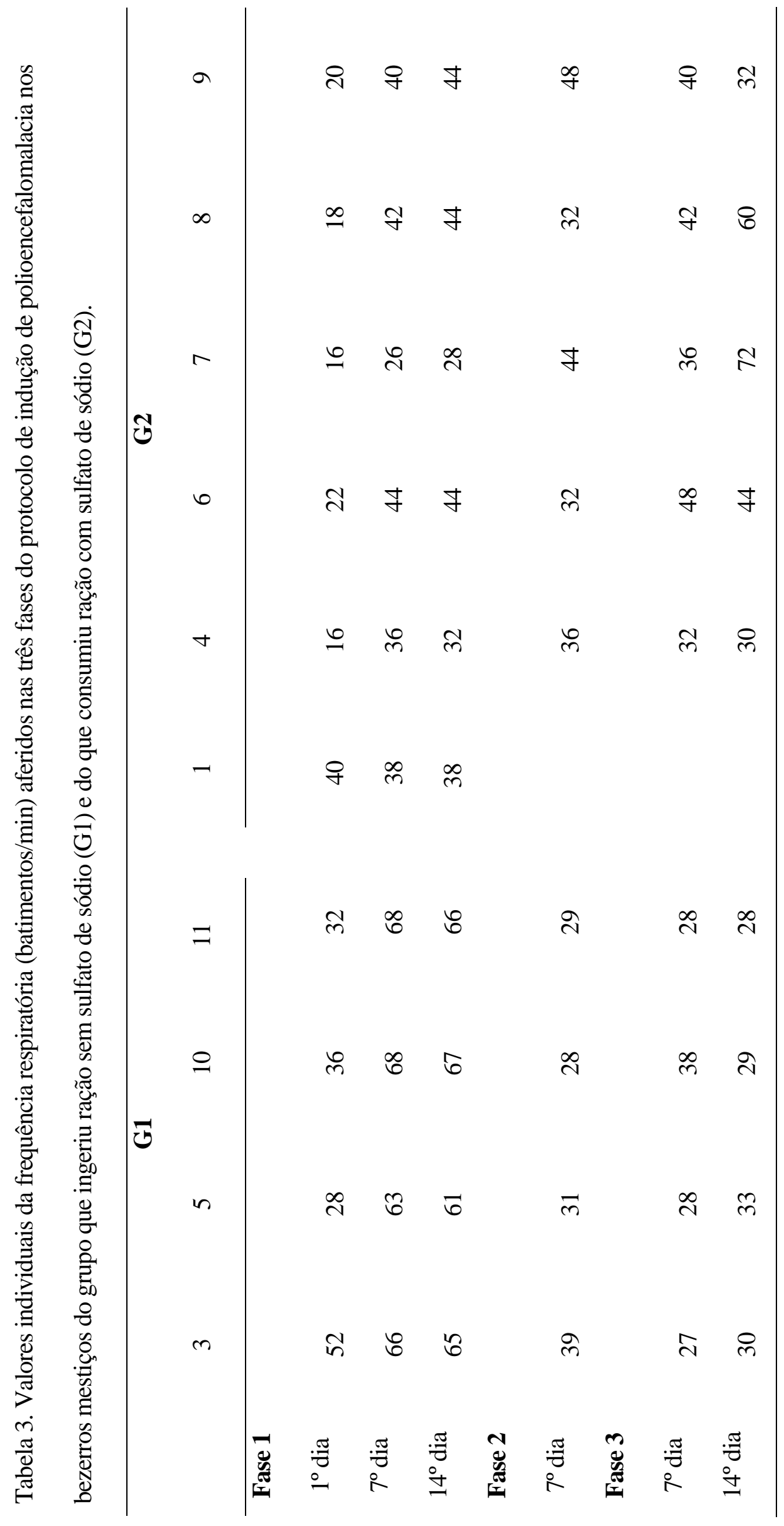




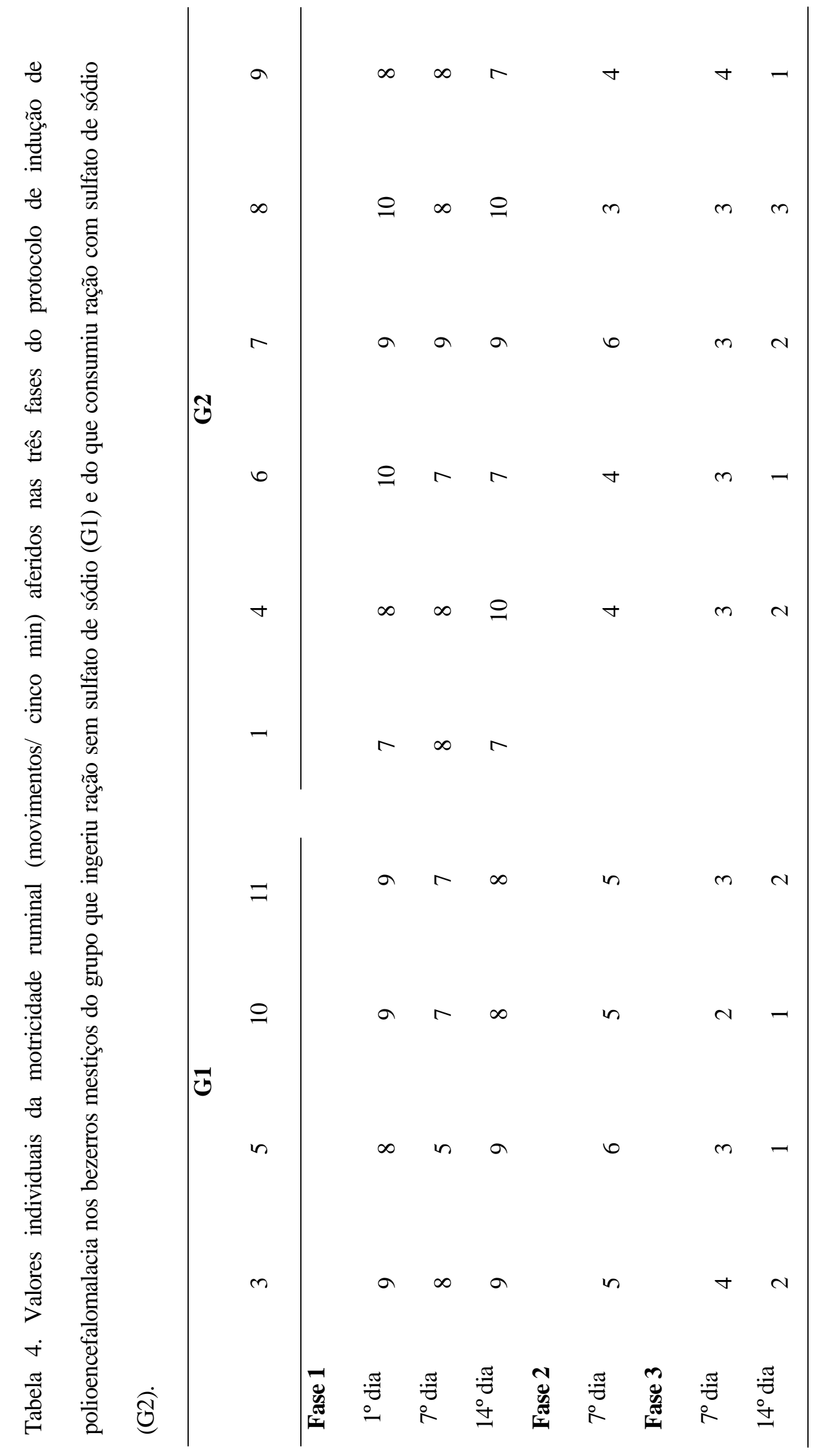




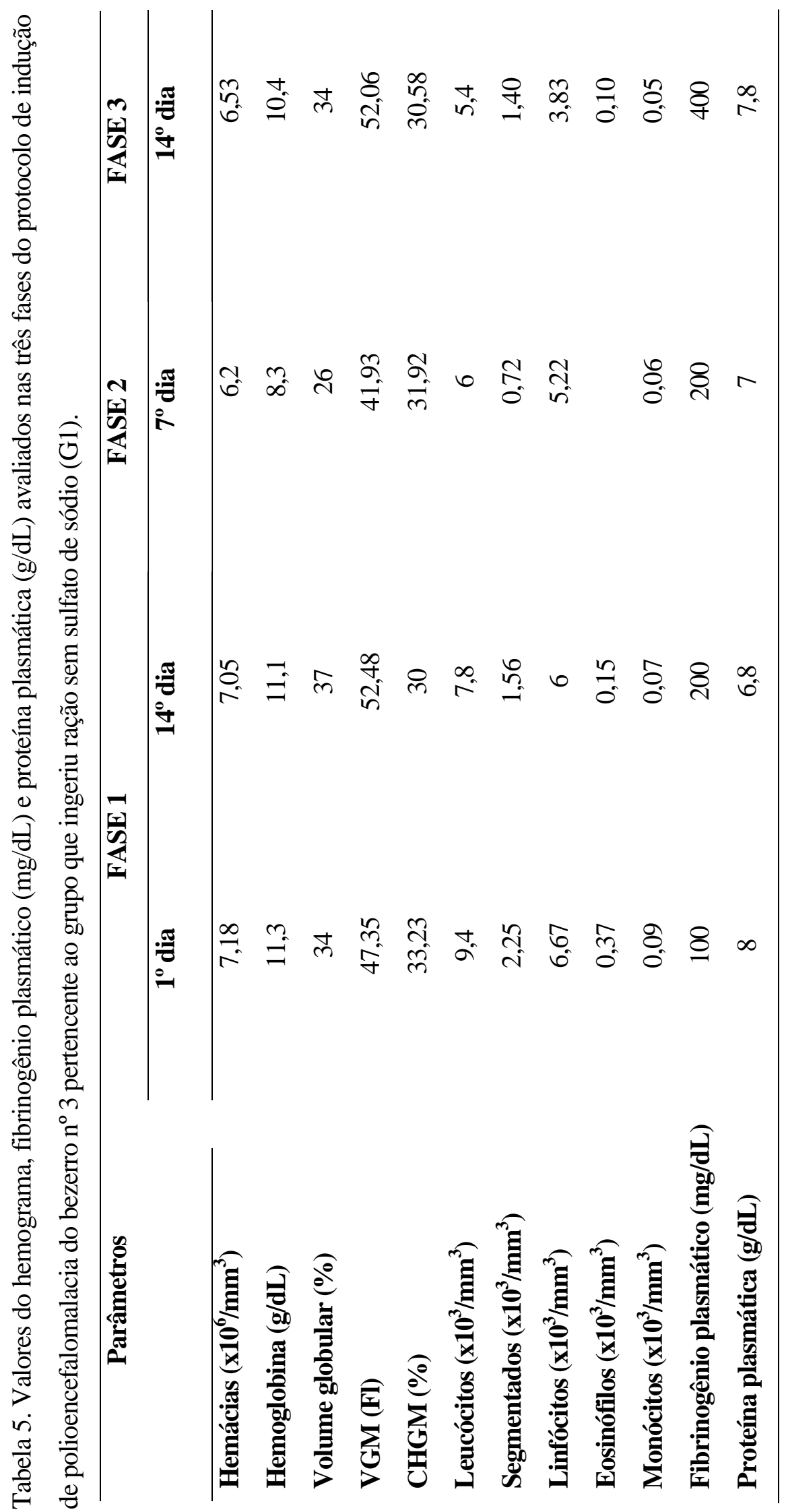




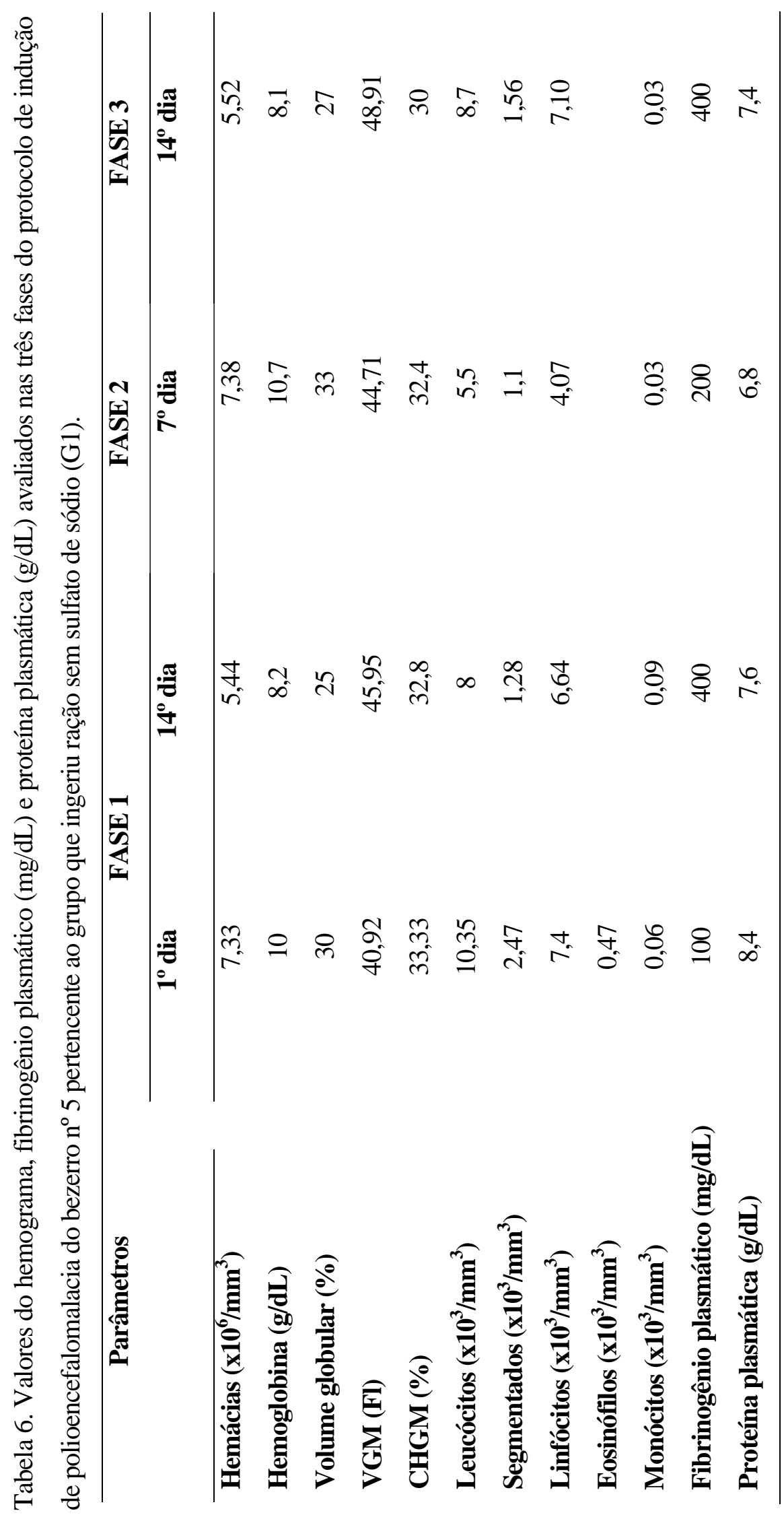




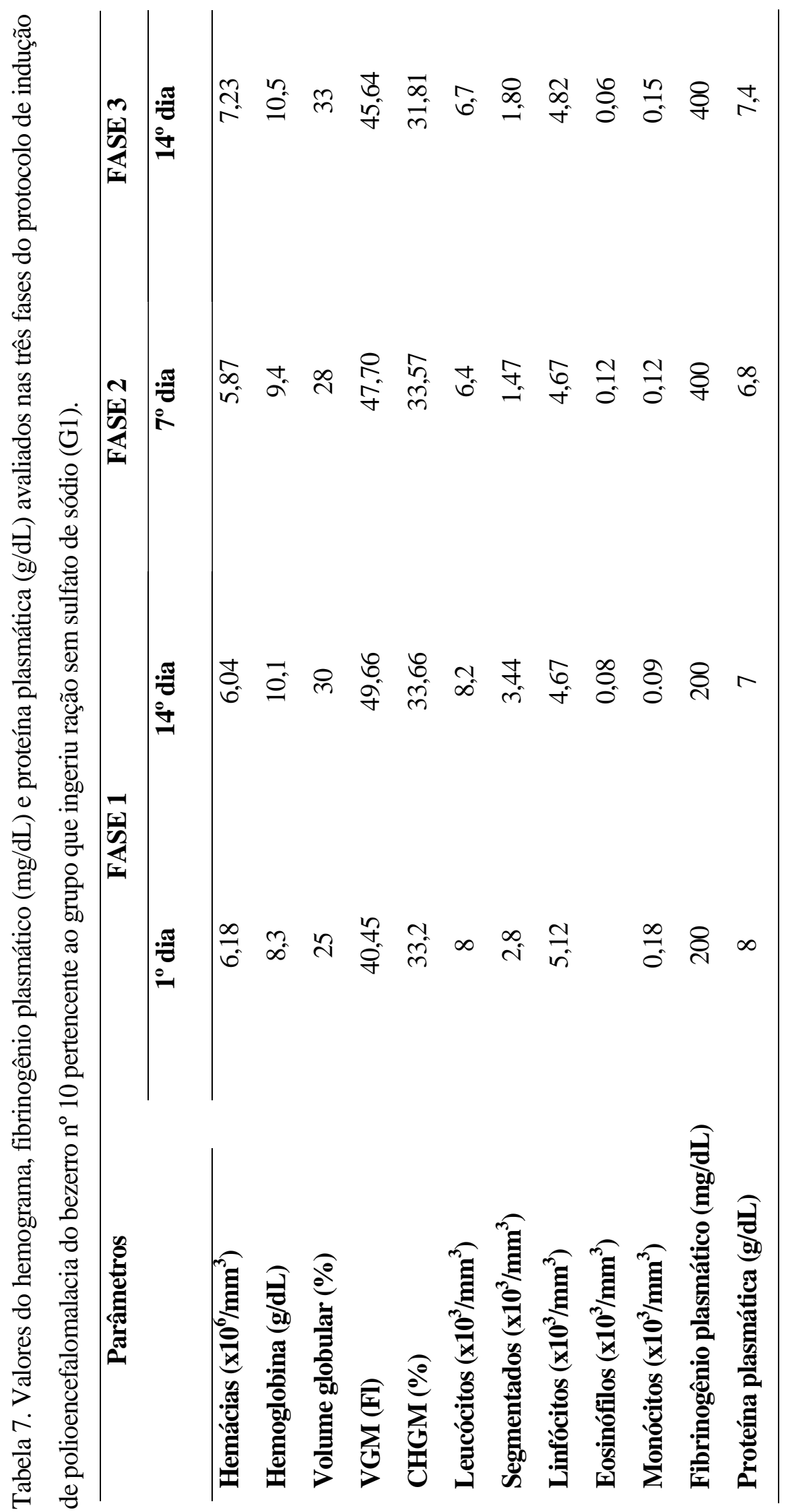




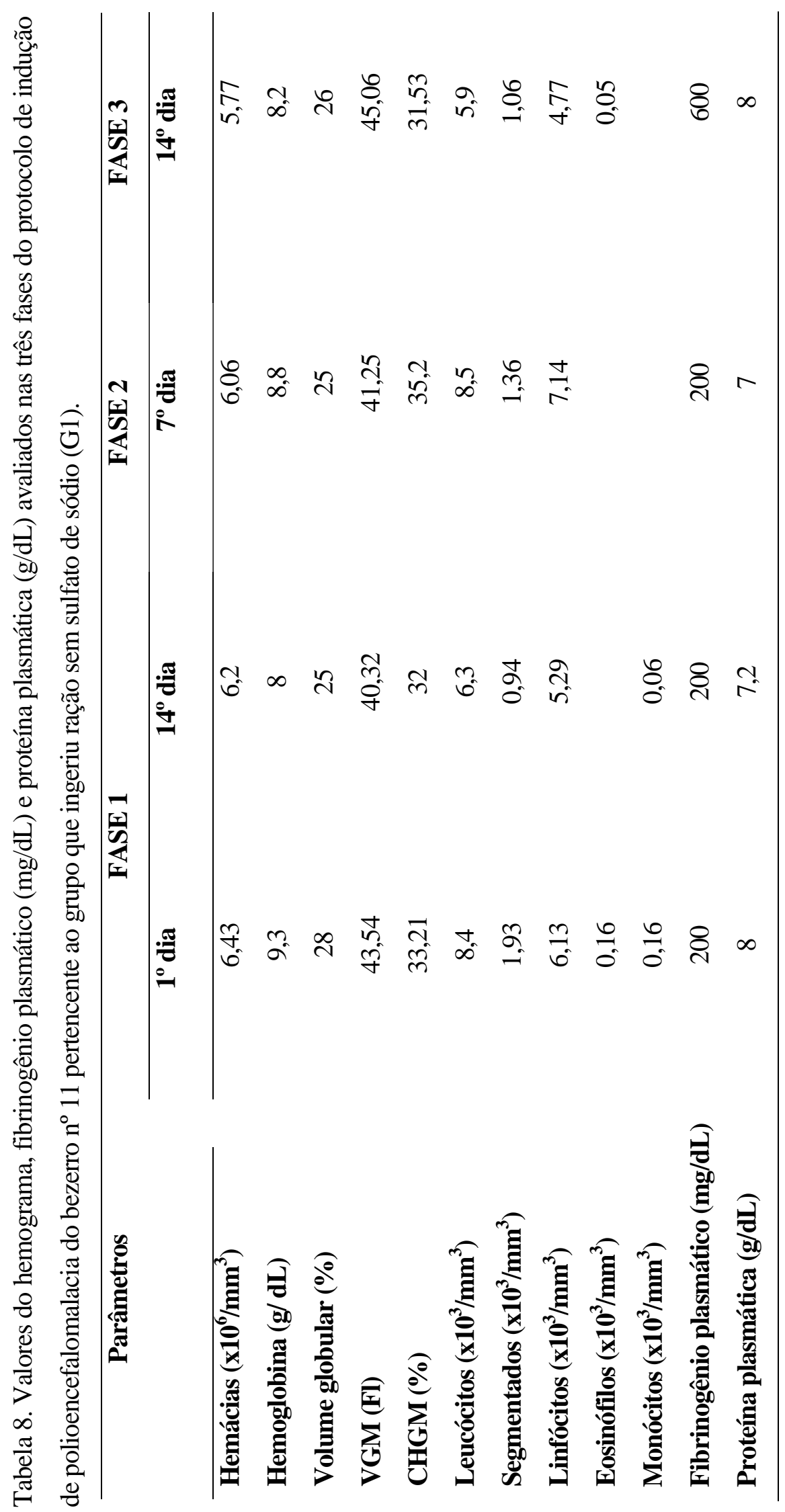




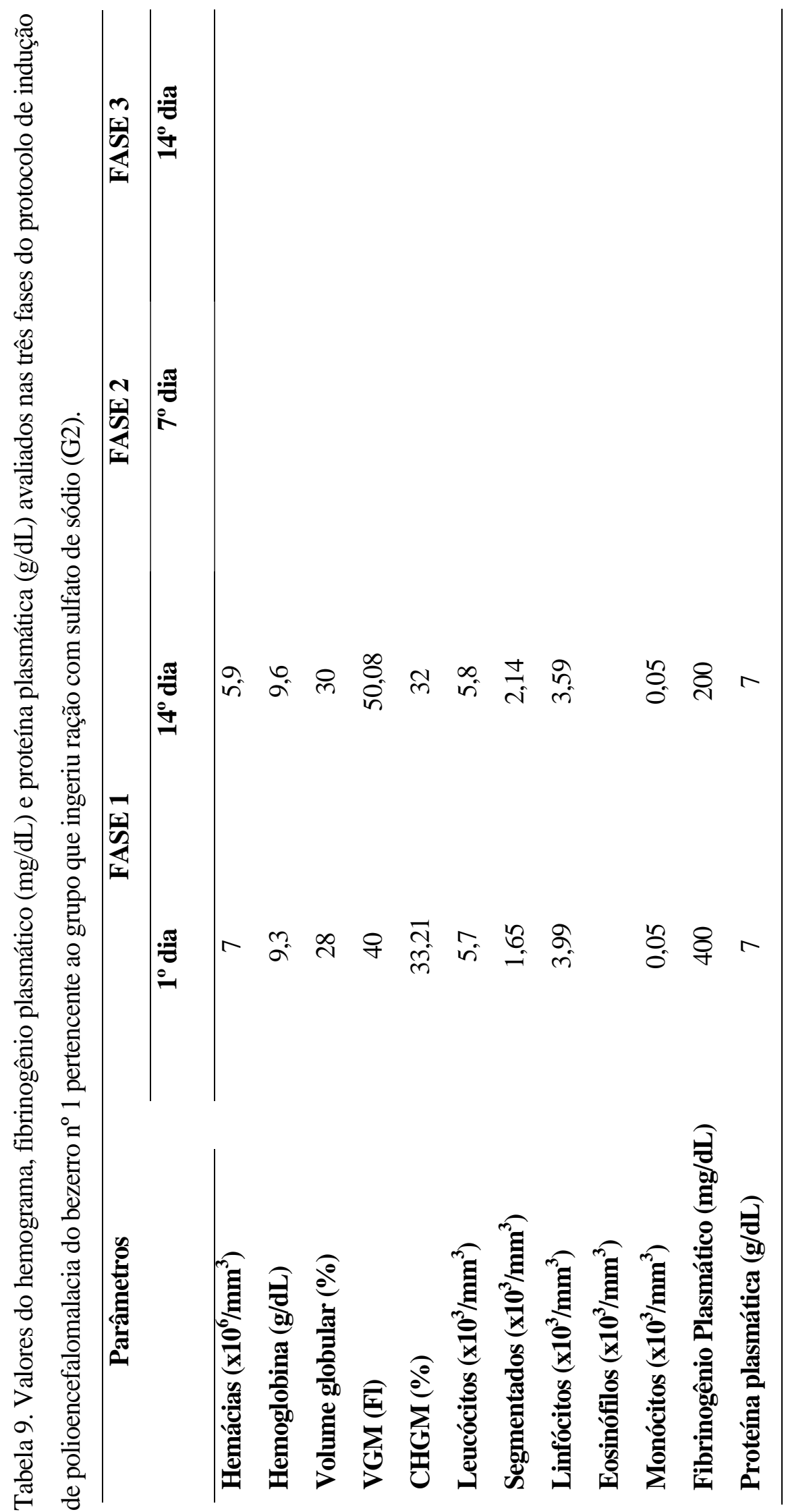




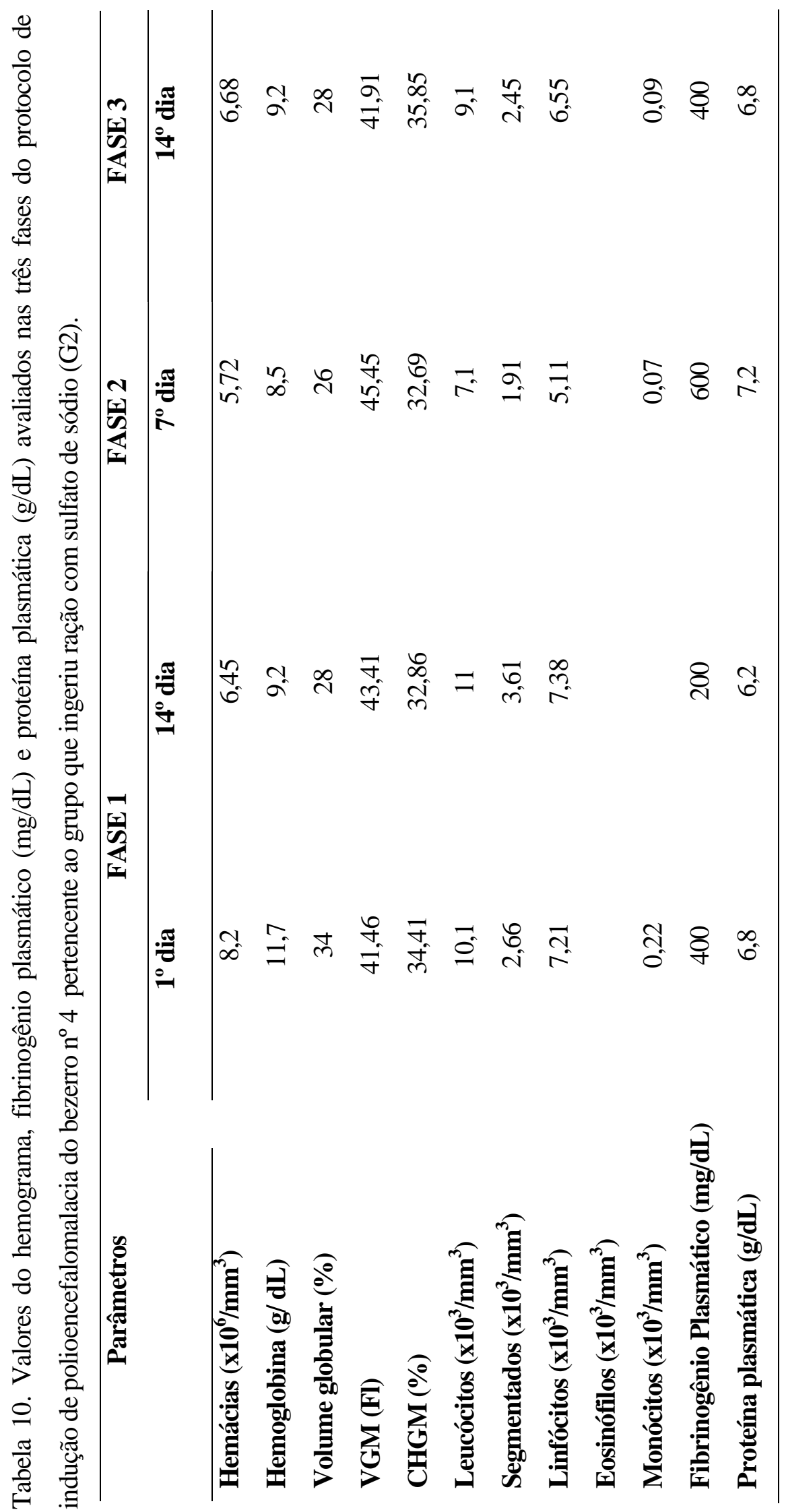




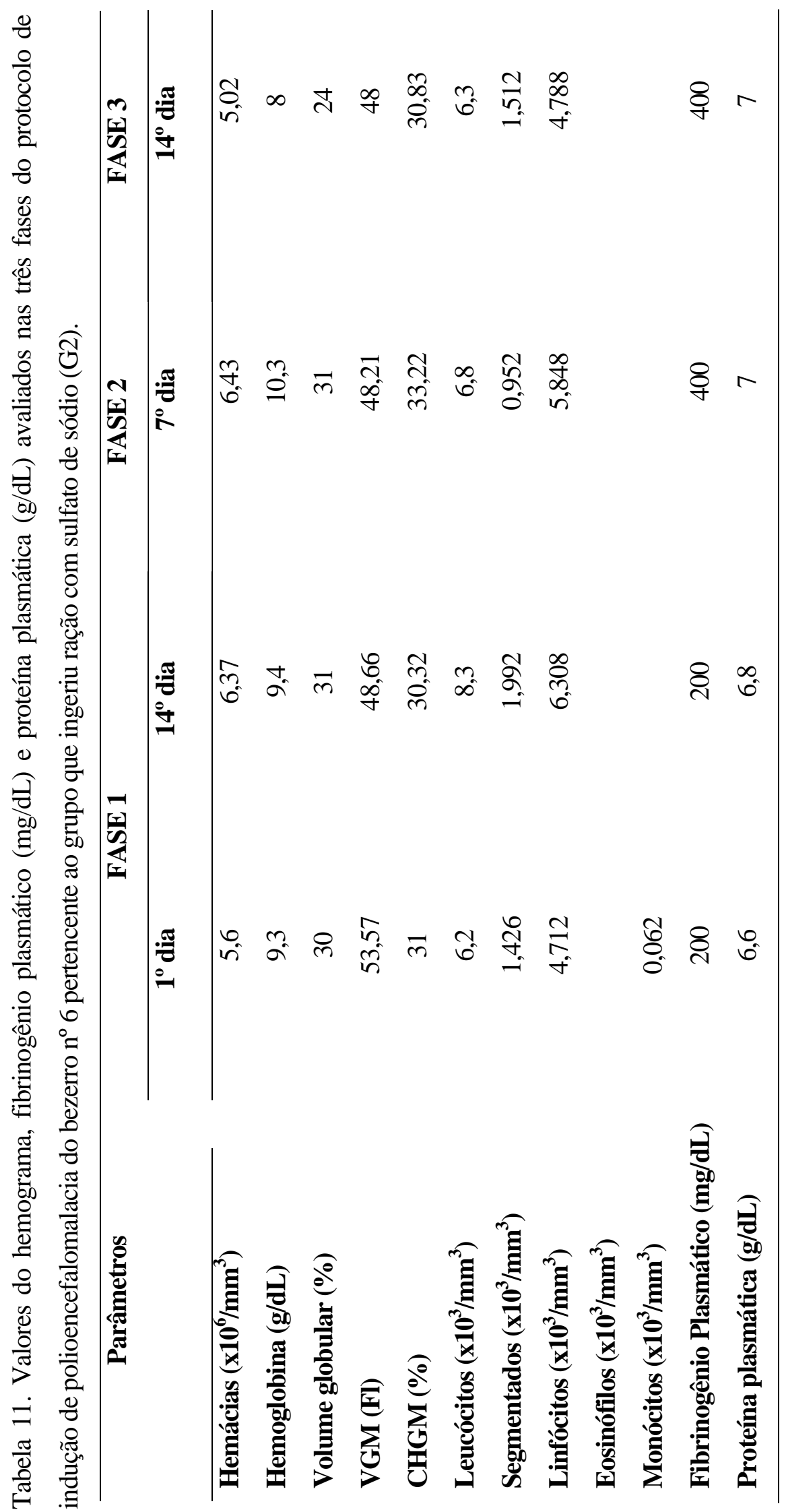




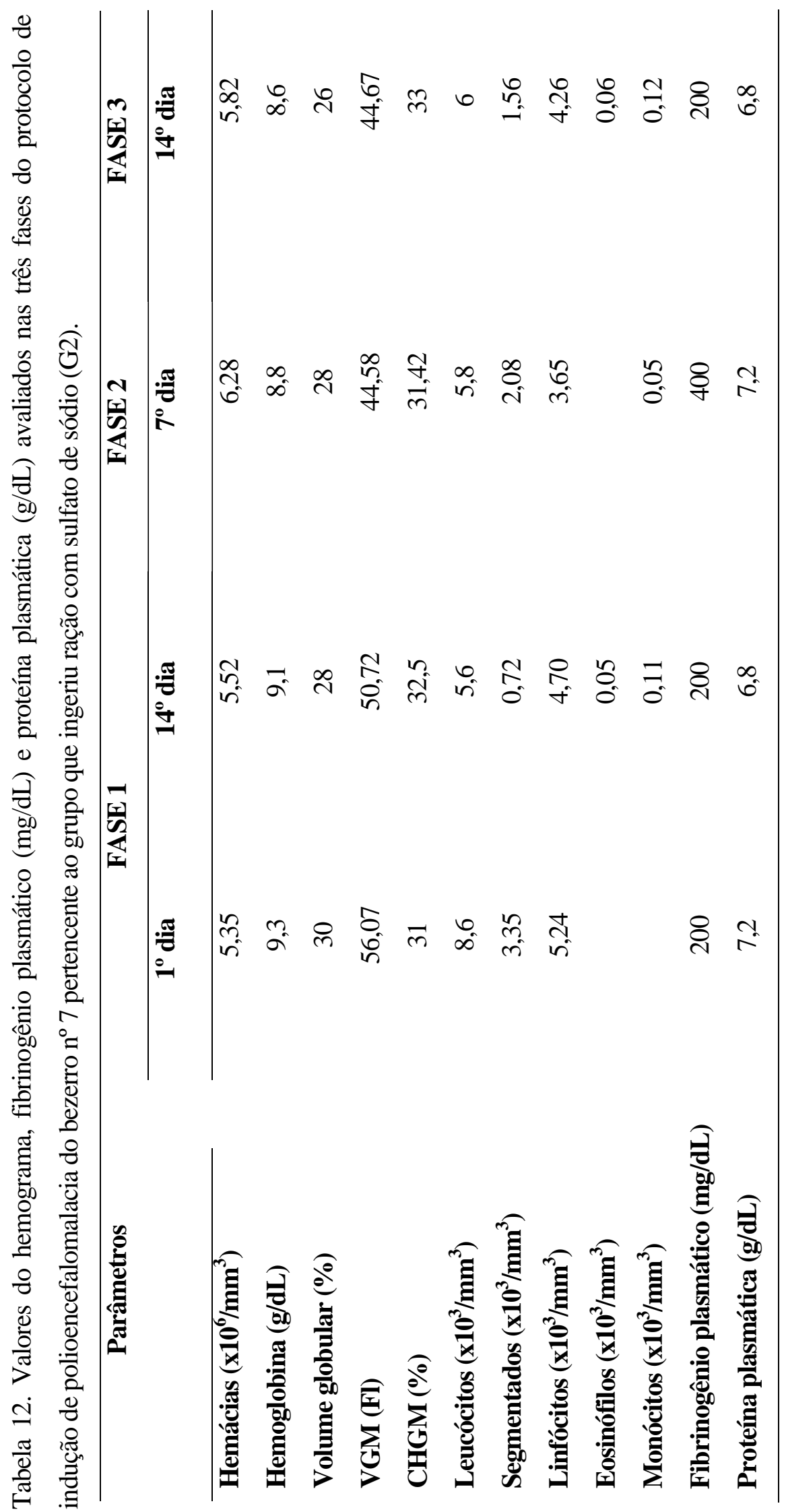




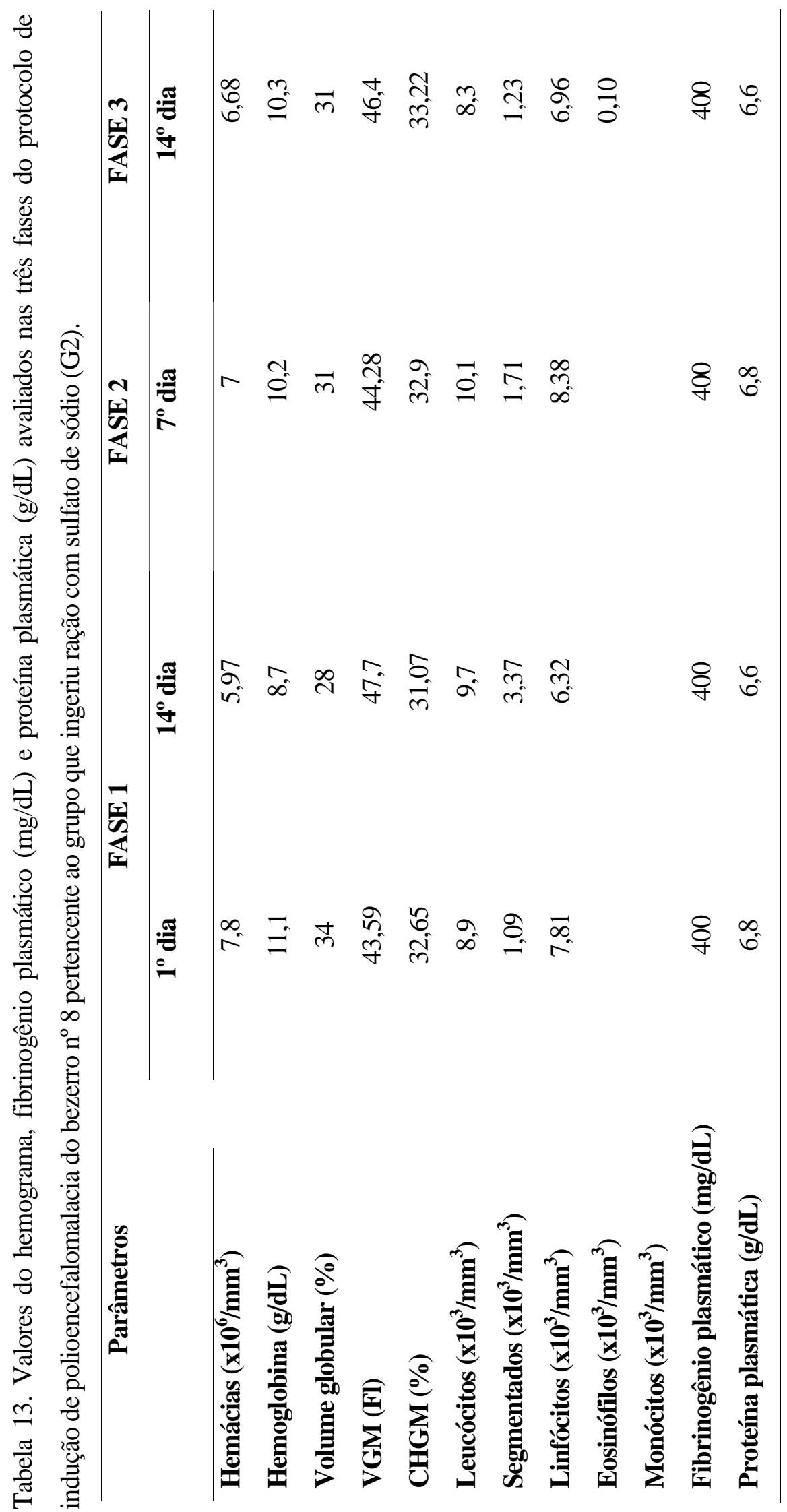




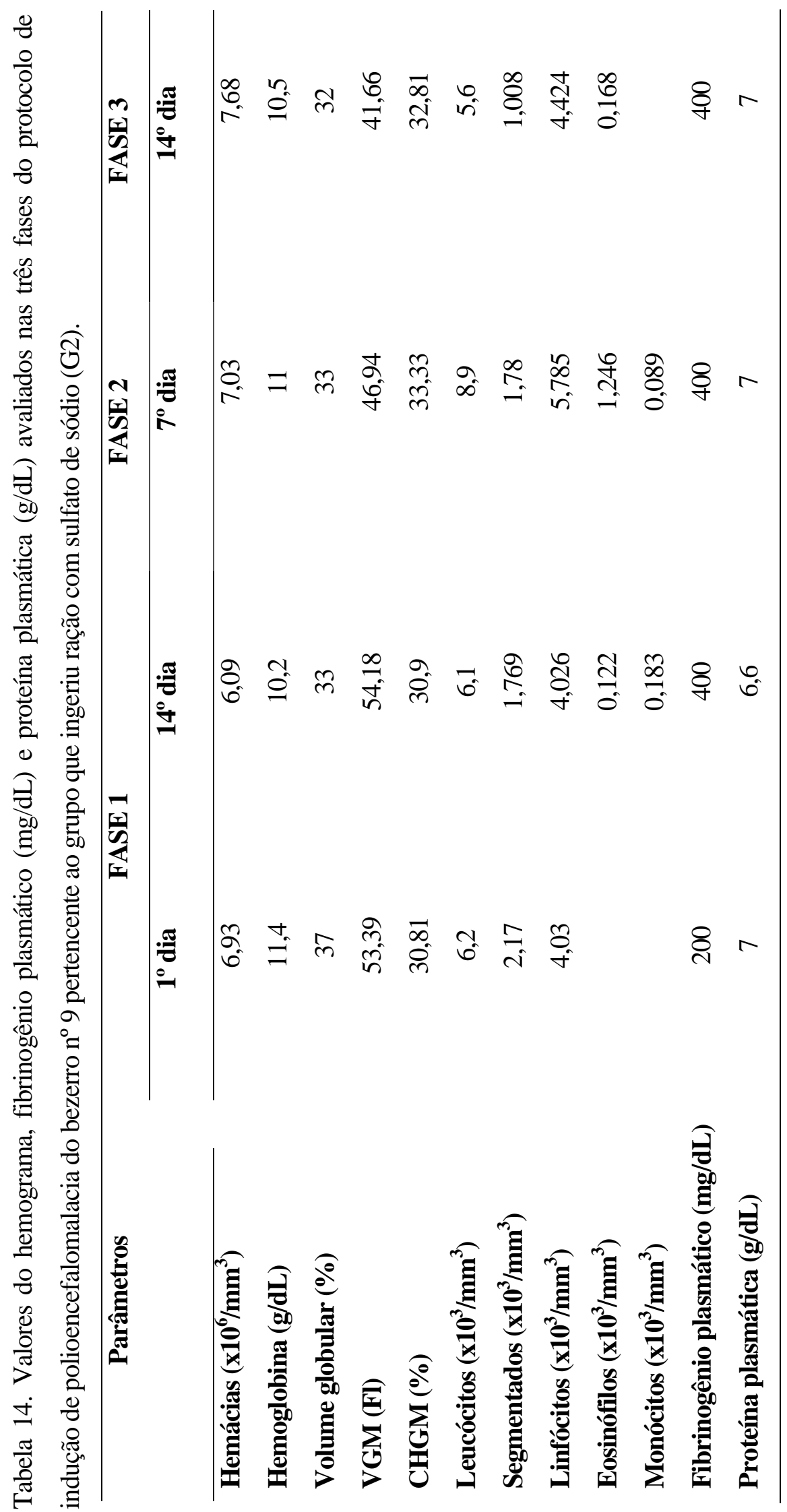




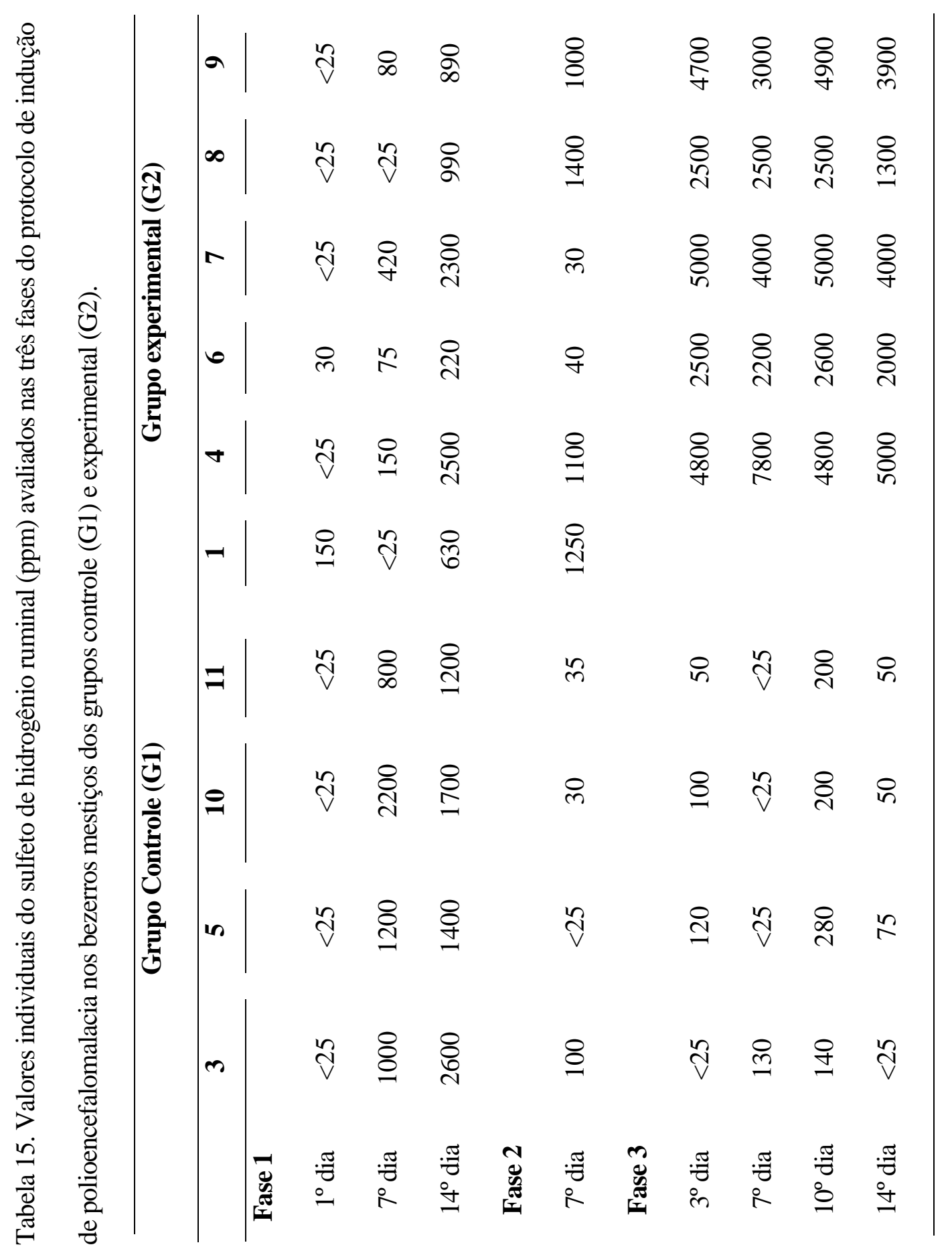




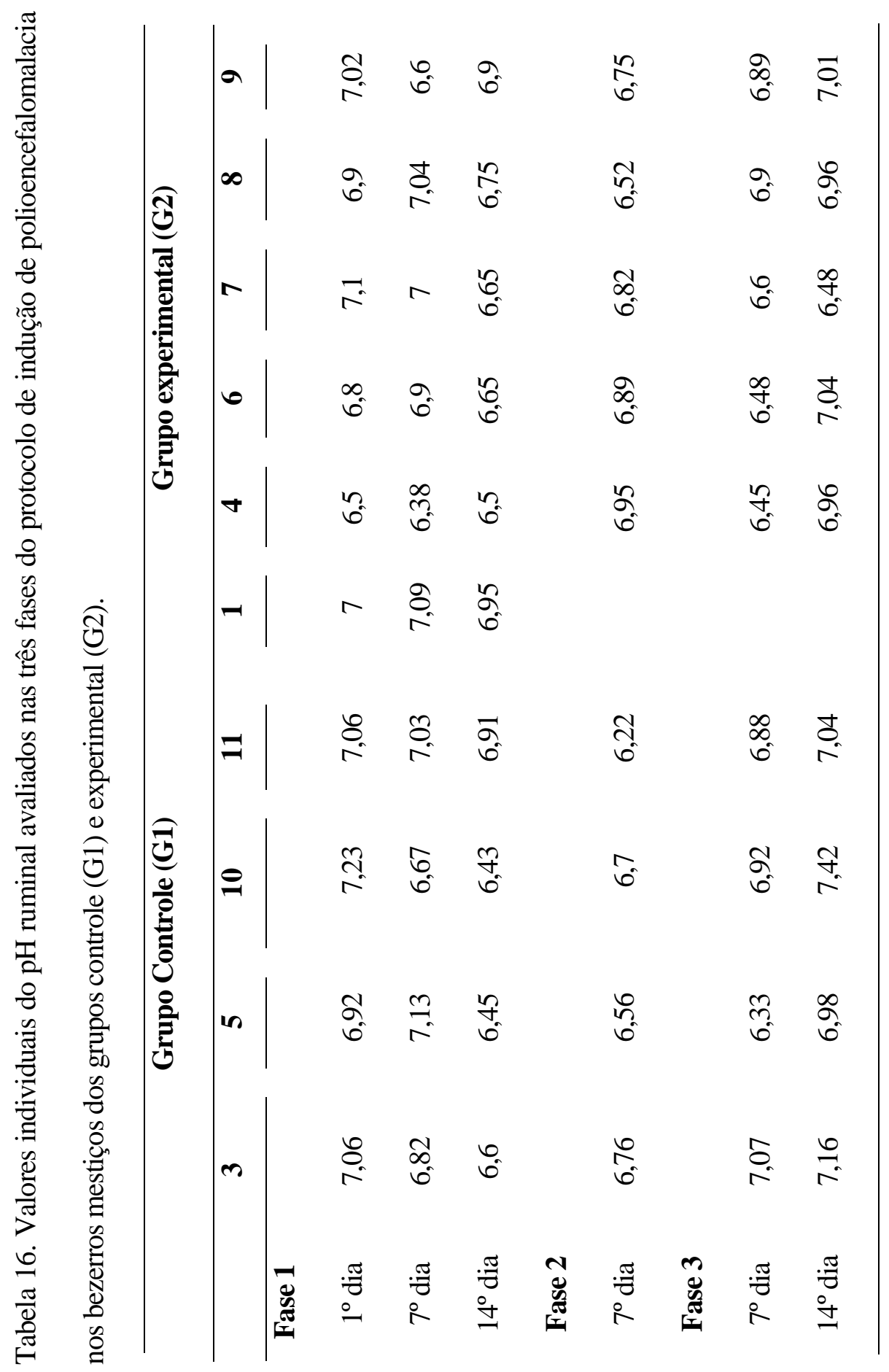


Tabela 17. Valores individuais da temperatura retal $\left({ }^{\circ} \mathrm{C}\right)$ aferidos durante período de 30 dias nos seis bezerros mestiços após infecção experimental com herpesvírus bovino 5 (BoHV-5).

\begin{tabular}{|c|c|c|c|c|c|c|}
\hline & \multicolumn{6}{|c|}{ Bezerros inoculados } \\
\hline Dias & 1 & 2 & 3 & 4 & 5 & 6 \\
\hline 0 & 38,9 & 38,6 & 38,6 & 38,8 & 38,9 & 39,0 \\
\hline 1 & 37,6 & 39,1 & 39,1 & 38,9 & 38,9 & 39,4 \\
\hline 2 & 38,9 & 38,8 & 39,9 & 40 & 39,5 & 39,3 \\
\hline 3 & 38,1 & 40,1 & 38,3 & 38,5 & 38,1 & 39,4 \\
\hline 4 & 39,3 & 40,3 & 39,1 & 39,4 & 39,2 & 40,6 \\
\hline 5 & 39,6 & 39,8 & 39,4 & 40,1 & 40,2 & 39,8 \\
\hline 6 & 39,4 & 39,2 & 39,6 & 40,2 & 40,3 & 40 \\
\hline 6 & 40,3 & 39,8 & 40 & 39,9 & 40,4 & 39,4 \\
\hline 7 & 38 & 39,9 & 37,5 & 38,7 & 39 & 40 \\
\hline 8 & 40,5 & 40 & 39,6 & 40,5 & 39,8 & 40 \\
\hline 9 & 39,7 & 39 & 39,5 & 40,2 & 40,3 & 39,7 \\
\hline 10 & 38,7 & 39,9 & 39,4 & 39,9 & 39,4 & 39,8 \\
\hline 11 & 37,6 & 37,7 & 40 & 39,6 & 39,7 & 40,3 \\
\hline 12 & 38,9 & 39,1 & 39,7 & 39 & 39,3 & 38,8 \\
\hline 13 & & 36,8 & 39,7 & 39,2 & 39,4 & 39,9 \\
\hline 14 & & 40 & 39,5 & 39,7 & 39,4 & 38,4 \\
\hline 15 & & 39,5 & 39,9 & 39,6 & 39,3 & 39,5 \\
\hline 16 & & 38,9 & 39,3 & 39,5 & 39,4 & 39,6 \\
\hline 17 & & 38,5 & 39,3 & 39,5 & 39,6 & 39,4 \\
\hline 18 & & 38,2 & 39,1 & 39,4 & 39,7 & 39,4 \\
\hline 19 & & 38,6 & 39,5 & 39,6 & 40,1 & 39,3 \\
\hline 20 & & 39,1 & 39,8 & 40 & 39,8 & 38,1 \\
\hline 21 & & 38,8 & 39,6 & 39,9 & 39,8 & 38,3 \\
\hline 22 & & & 39,7 & 39,8 & 39,5 & 38,4 \\
\hline 23 & & & 39 & 40,3 & 39,7 & 39,5 \\
\hline 24 & & & 38,8 & 38,5 & 39,3 & 37,5 \\
\hline 25 & & & 39,2 & 39,1 & 39,2 & 38,7 \\
\hline 26 & & & 37,5 & 37,6 & 37,6 & 40,3 \\
\hline 27 & & & 37,5 & 39,2 & 38,8 & 39,4 \\
\hline 28 & & & 38,8 & 39,4 & 37,5 & 39,8 \\
\hline 29 & & & 38,5 & 39,3 & 38,8 & 38,3 \\
\hline 30 & & & 39,1 & 38,9 & 38,9 & 39,4 \\
\hline
\end{tabular}


Tabela 18. Valores individuais da frequência cardíaca (batimentos/min) aferidos durante período de 30 dias nos seis bezerros mestiços após infecção experimental com herpesvírus bovino 5 (BoHV-5).

\begin{tabular}{|c|c|c|c|c|c|c|}
\hline \multicolumn{7}{|c|}{ Bezerros inoculados } \\
\hline Dias & 1 & 2 & 3 & 4 & 5 & 6 \\
\hline 0 & 60 & 78 & 66 & 90 & 80 & 76 \\
\hline 1 & 58 & 80 & 76 & 90 & 76 & 73 \\
\hline 2 & 84 & 96 & 54 & 60 & 68 & 76 \\
\hline 3 & 75 & 68 & 68 & 64 & 58 & 64 \\
\hline 4 & 68 & 88 & 60 & 72 & 82 & 54 \\
\hline 5 & 58 & 76 & 60 & 72 & 64 & 78 \\
\hline 6 & 64 & 76 & 60 & 88 & 80 & 64 \\
\hline 6 & 76 & 72 & 52 & 84 & 60 & 88 \\
\hline 7 & 88 & 76 & 81 & 91 & 80 & 88 \\
\hline 8 & 70 & 64 & 72 & 84 & 72 & 96 \\
\hline 9 & 63 & 64 & 88 & 74 & 72 & 88 \\
\hline 10 & 88 & 52 & 72 & 61 & 64 & 64 \\
\hline 11 & 58 & 76 & 96 & 80 & 72 & 65 \\
\hline 12 & 84 & 59 & 60 & 72 & 68 & 78 \\
\hline 13 & & 69 & 60 & 68 & 88 & 68 \\
\hline 14 & & 52 & 80 & 76 & 56 & 68 \\
\hline 15 & & 84 & 64 & 68 & 64 & 57 \\
\hline 16 & & 68 & 60 & 72 & 68 & 60 \\
\hline 17 & & 76 & 74 & 77 & 84 & 72 \\
\hline 18 & & 64 & 52 & 82 & 72 & 76 \\
\hline 19 & & 52 & 64 & 72 & 88 & 60 \\
\hline 20 & & 76 & 64 & 64 & 72 & 62 \\
\hline 21 & & 80 & 96 & 72 & 51 & 56 \\
\hline 22 & & & 56 & 80 & 49 & 60 \\
\hline 23 & & & 48 & 72 & 81 & 64 \\
\hline 24 & & & 52 & 72 & 69 & 60 \\
\hline 25 & & & 60 & 72 & 87 & 76 \\
\hline 26 & & & 58 & 69 & 88 & 52 \\
\hline 27 & & & 54 & 71 & 71 & 58 \\
\hline 28 & & & 50 & 73 & 86 & 59 \\
\hline 29 & & & 66 & 90 & 66 & 57 \\
\hline 30 & & & 76 & 90 & 76 & 73 \\
\hline
\end{tabular}


Tabela 19. Valores individuais da frequência respiratória (movimentos/min) aferidos durante período de 30 dias nos seis bezerros mestiços após infecção experimental com herpesvírus bovino 5 (BoHV-5).

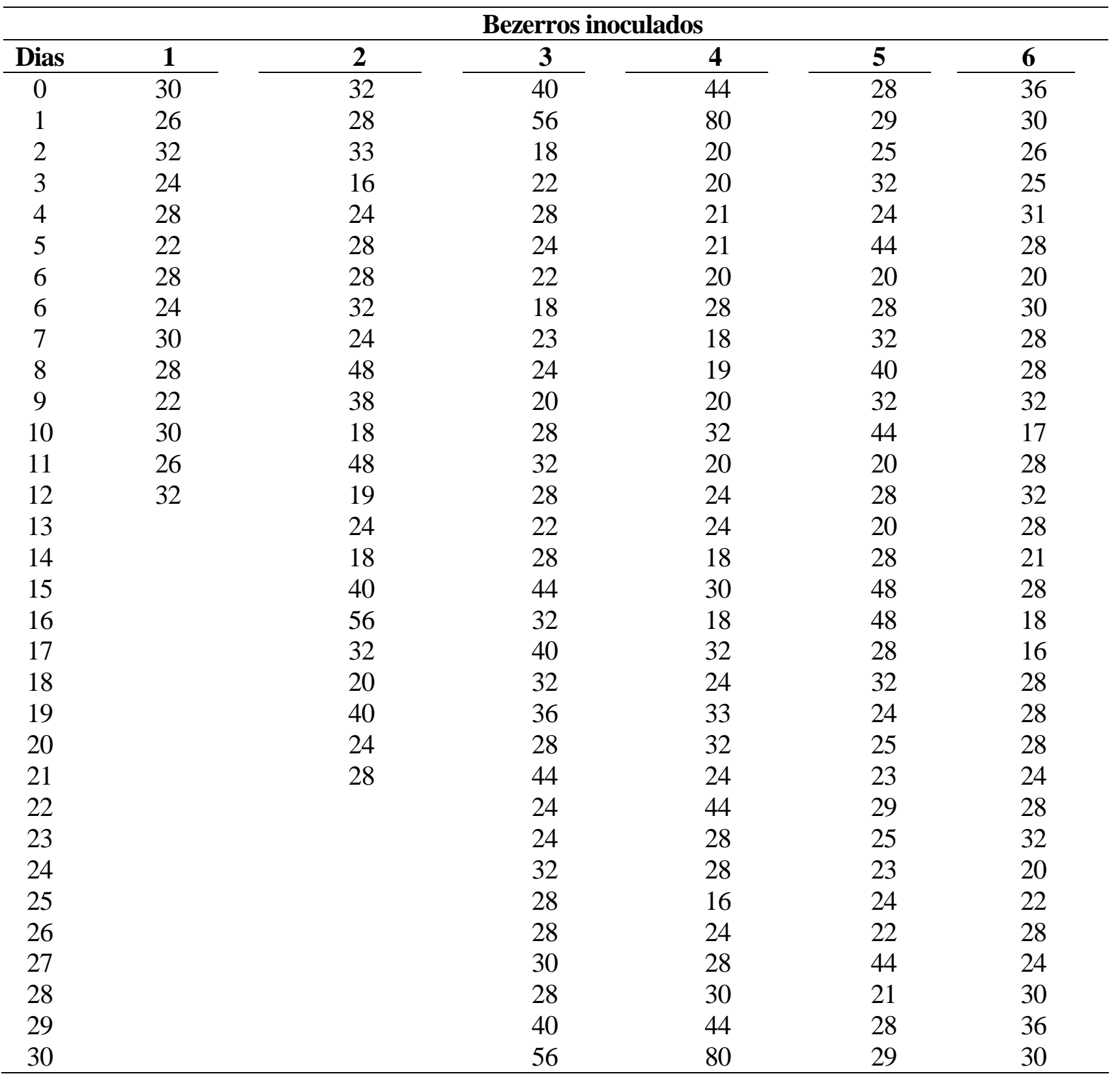


Tabela 20. Valores individuais da motricidade ruminal (movimentos/cinco min) aferidos durante período de 30 dias nos seis bezerros mestiços após infecção experimental com herpesvírus bovino 5 (BoHV-5).

\begin{tabular}{|c|c|c|c|c|c|c|}
\hline \multicolumn{7}{|c|}{ Bezerros inoculados } \\
\hline Dias & 1 & 2 & 3 & 4 & 5 & 6 \\
\hline 0 & 7 & 9 & 8 & 9 & 9 & 8 \\
\hline 1 & 7 & 8 & 8 & 8 & 10 & 9 \\
\hline 2 & 8 & 7 & 7 & 7 & 9 & 7 \\
\hline 3 & 8 & 7 & 8 & 7 & 9 & 9 \\
\hline 4 & 7 & 8 & 8 & 8 & 8 & 7 \\
\hline 5 & 9 & 9 & 9 & 8 & 8 & 7 \\
\hline 6 & 10 & 8 & 7 & 9 & 8 & 8 \\
\hline 6 & 7 & 8 & 8 & 7 & 9 & 7 \\
\hline 7 & 8 & 7 & 9 & 9 & 8 & 8 \\
\hline 8 & 7 & 7 & 7 & 8 & 9 & 8 \\
\hline 9 & 7 & 7 & 8 & 8 & 9 & 9 \\
\hline 10 & 7 & 8 & 8 & 7 & 8 & 7 \\
\hline 11 & 7 & 8 & 8 & 7 & 10 & 8 \\
\hline 12 & 8 & 8 & 8 & 9 & 10 & 8 \\
\hline 13 & & 9 & 8 & 8 & 8 & 8 \\
\hline 14 & & 8 & 9 & 8 & 8 & 8 \\
\hline 15 & & 9 & 7 & 7 & 8 & 8 \\
\hline 16 & & 8 & 7 & 8 & 9 & 8 \\
\hline 17 & & 7 & 8 & 9 & 8 & 8 \\
\hline 18 & & 8 & 9 & 8 & 9 & 8 \\
\hline 19 & & 8 & 8 & 9 & 8 & 9 \\
\hline 20 & & 9 & 8 & 7 & 9 & 8 \\
\hline 21 & & 8 & 8 & 9 & 7 & 9 \\
\hline 22 & & & 7 & 8 & 8 & 9 \\
\hline 23 & & & 8 & 7 & 7 & 10 \\
\hline 24 & & & 8 & 10 & 9 & 9 \\
\hline 25 & & & 7 & 9 & 9 & 8 \\
\hline 26 & & & 8 & 8 & 8 & 9 \\
\hline 27 & & & 7 & 8 & 8 & 8 \\
\hline 28 & & & 8 & 7 & 7 & 9 \\
\hline 29 & & & 8 & 9 & 9 & 9 \\
\hline 30 & & & 8 & 8 & 10 & 9 \\
\hline
\end{tabular}




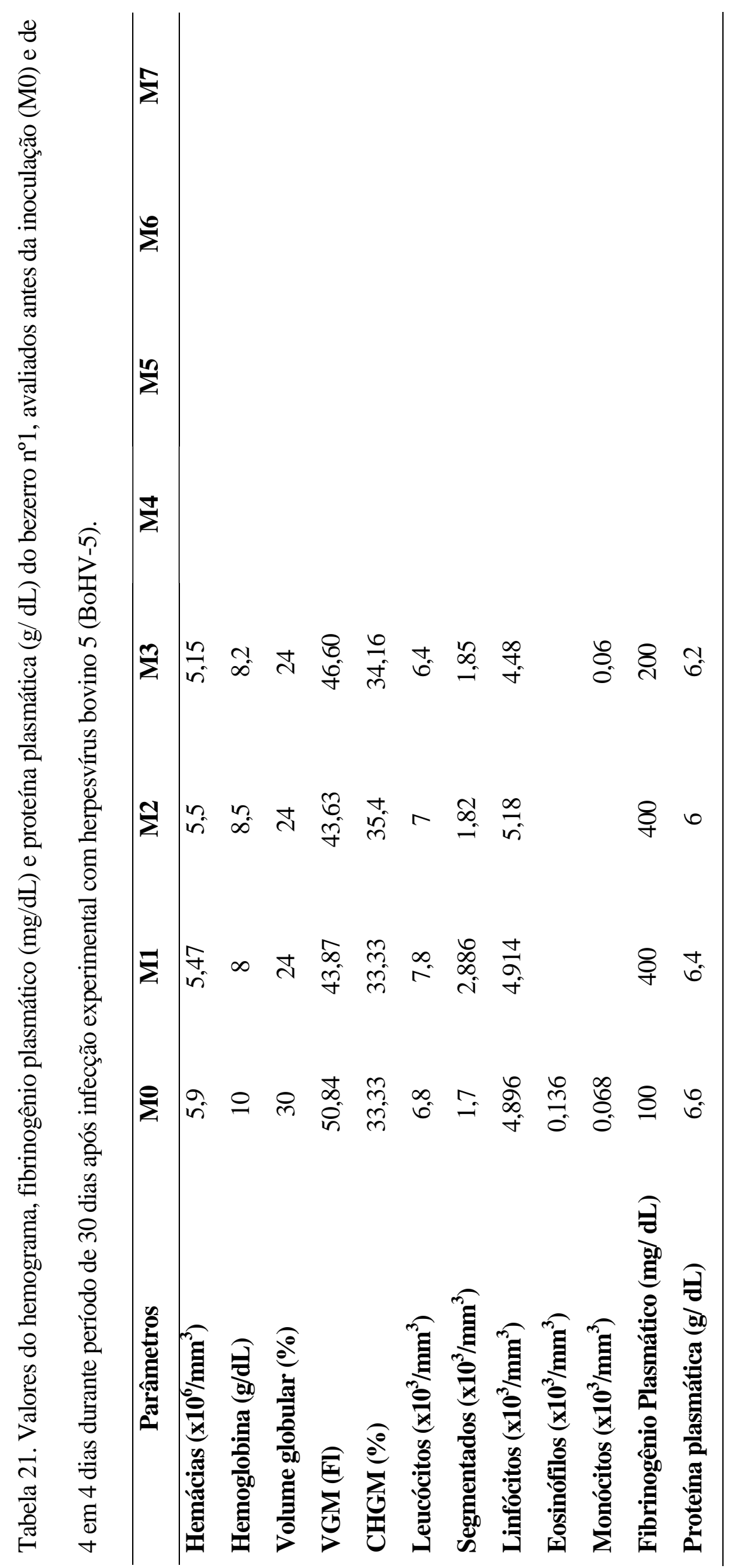




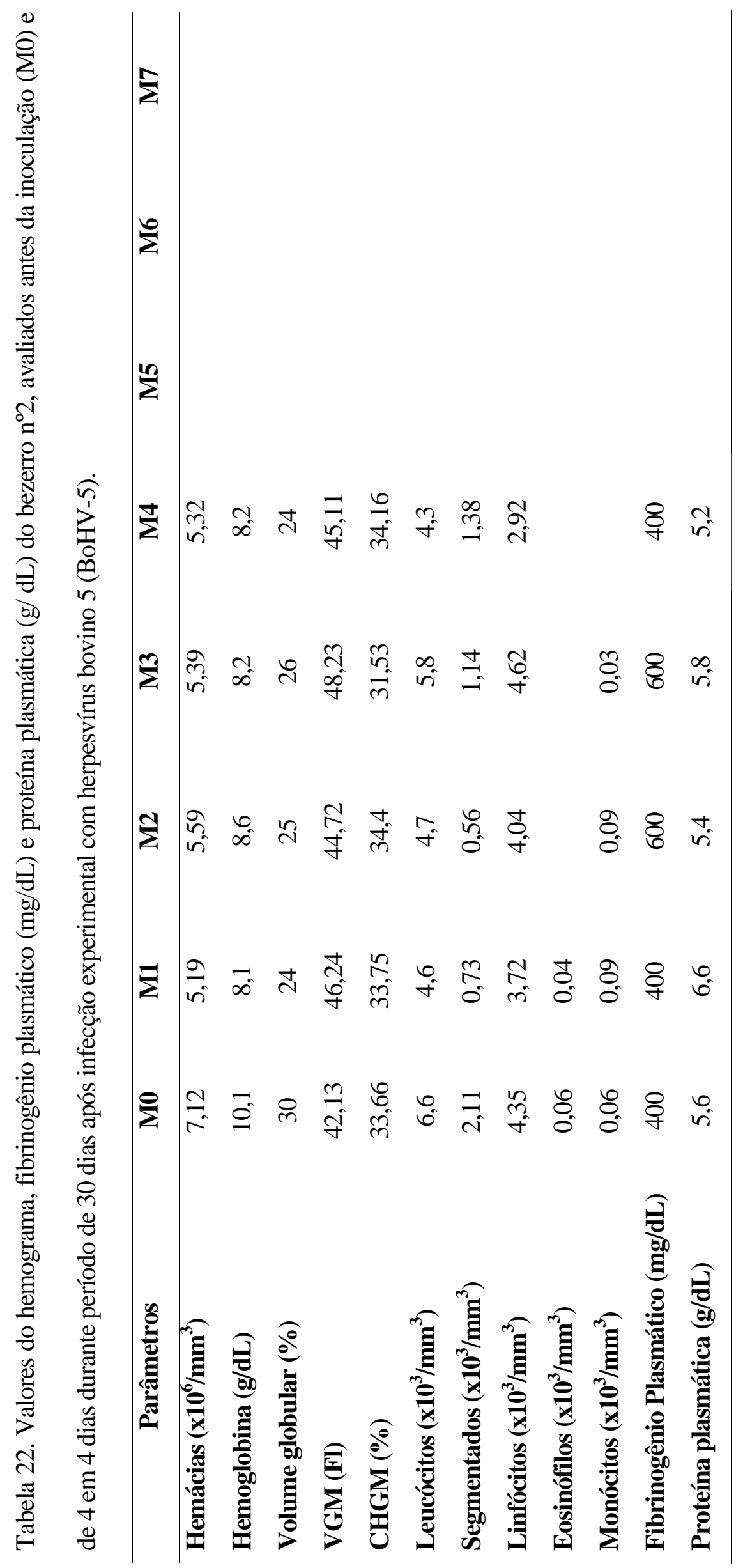




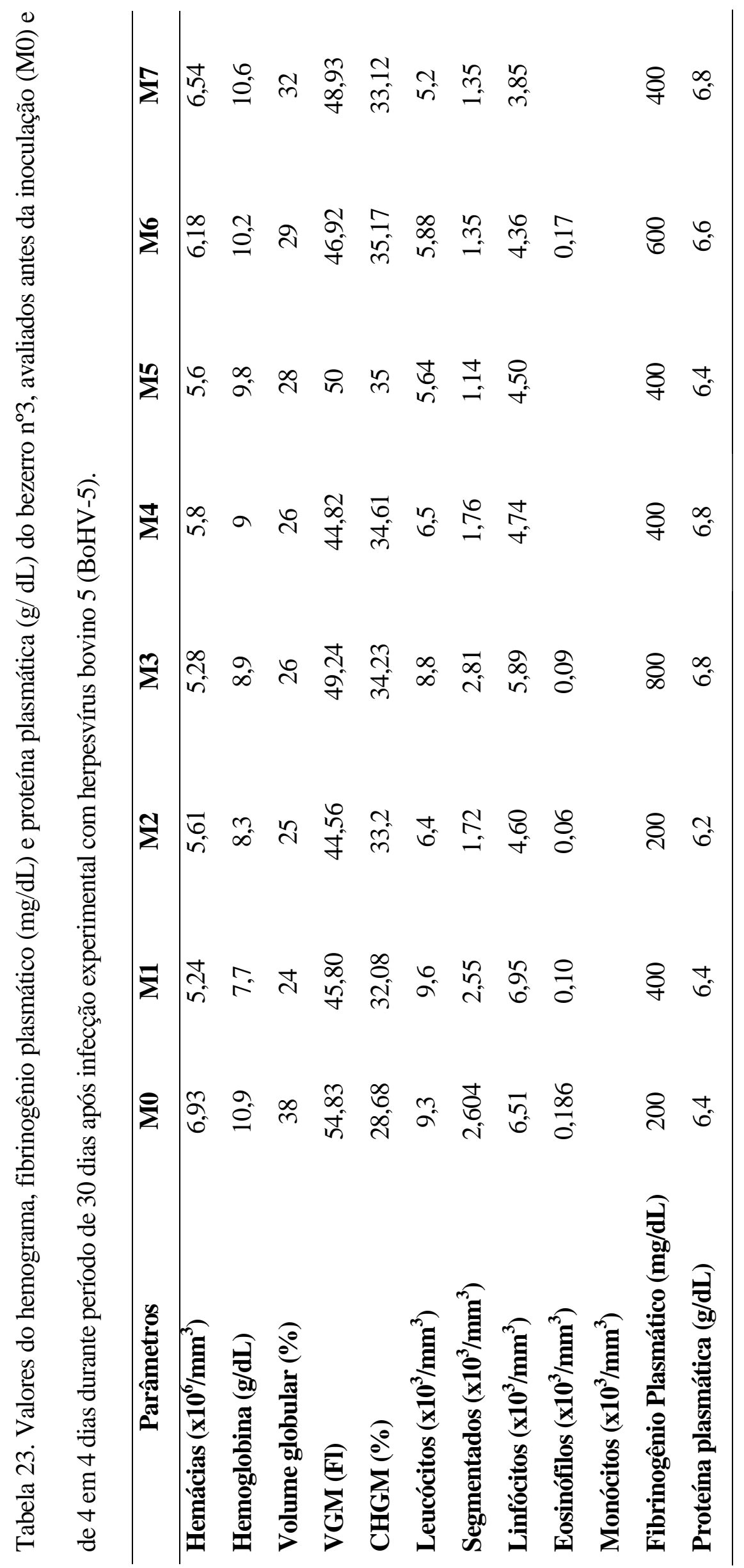




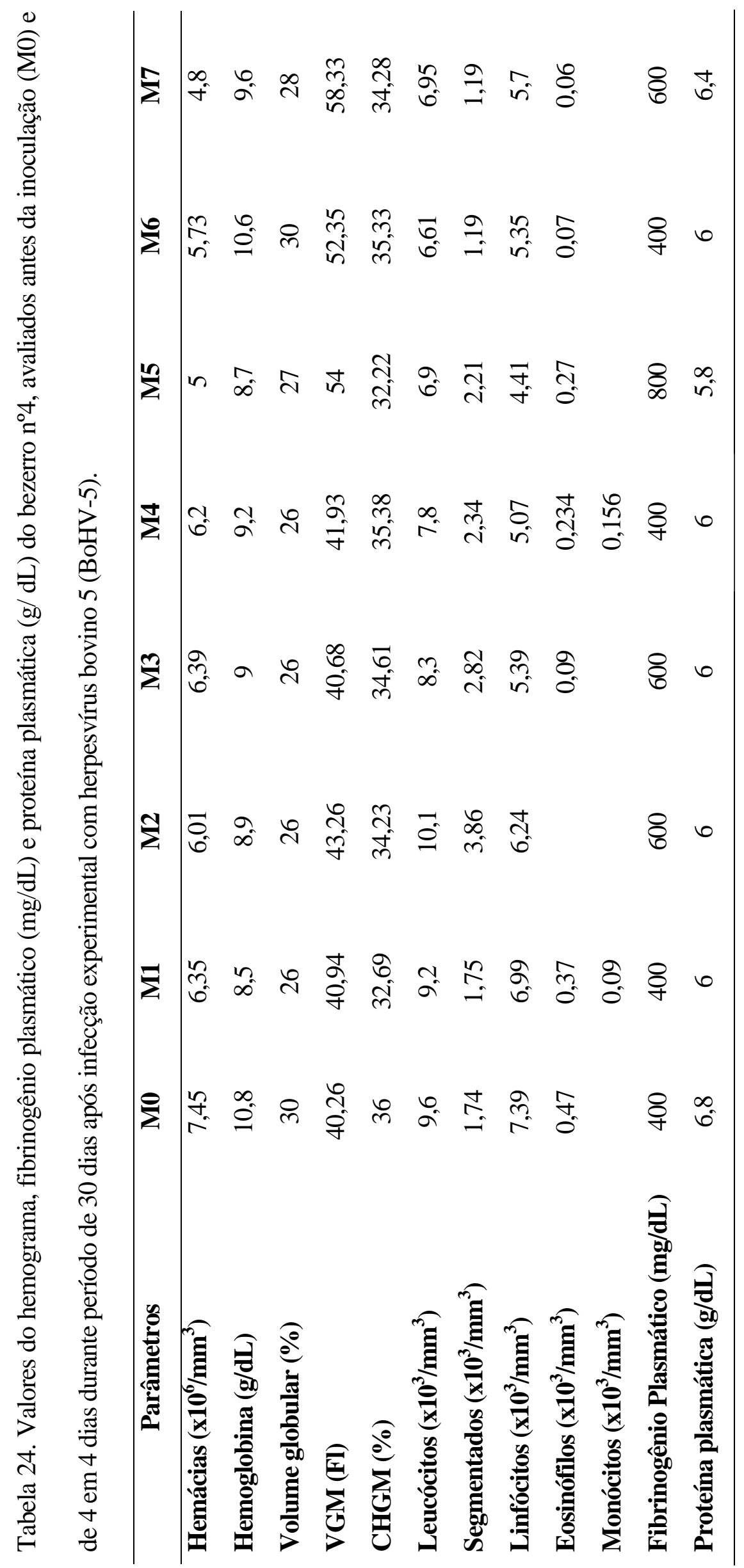




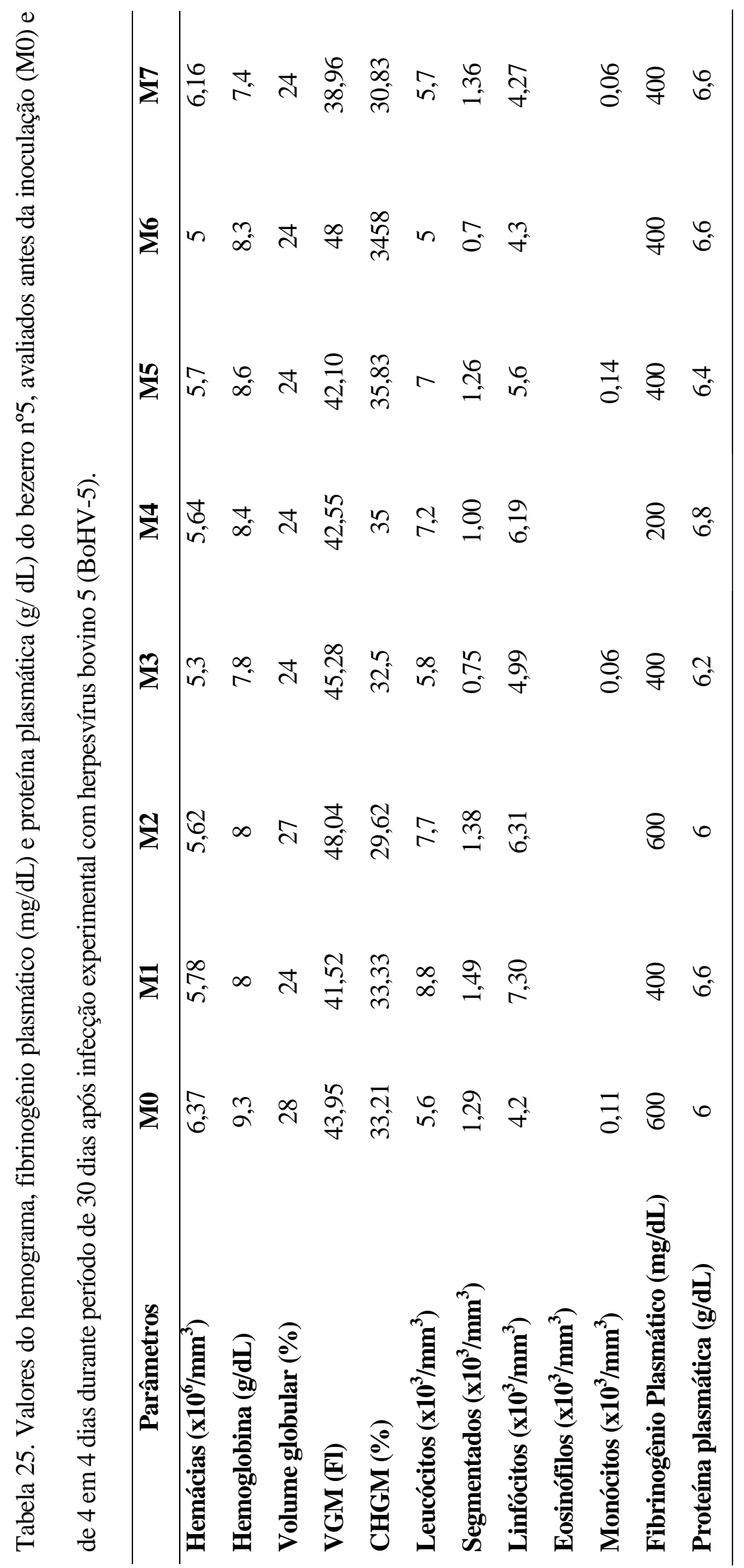




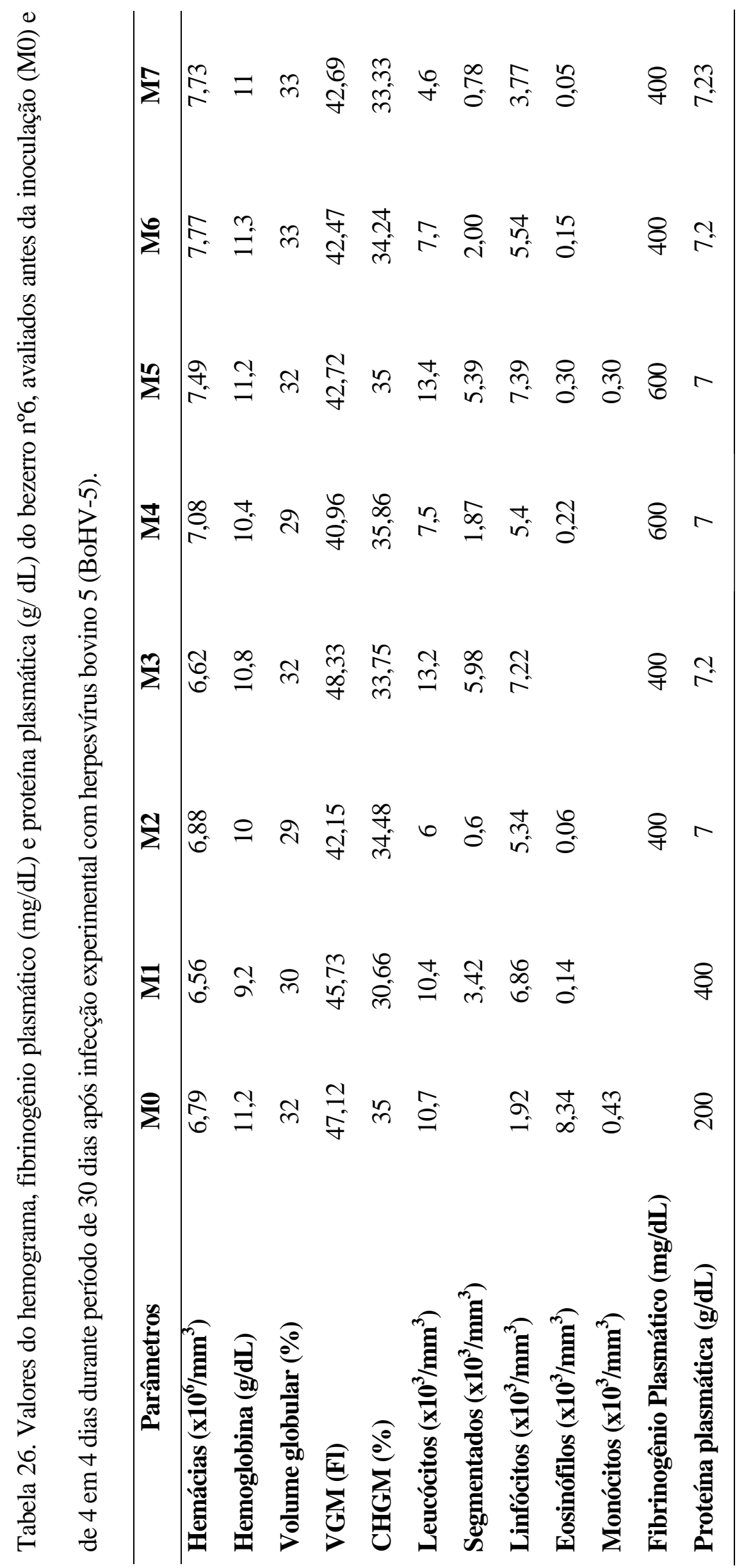




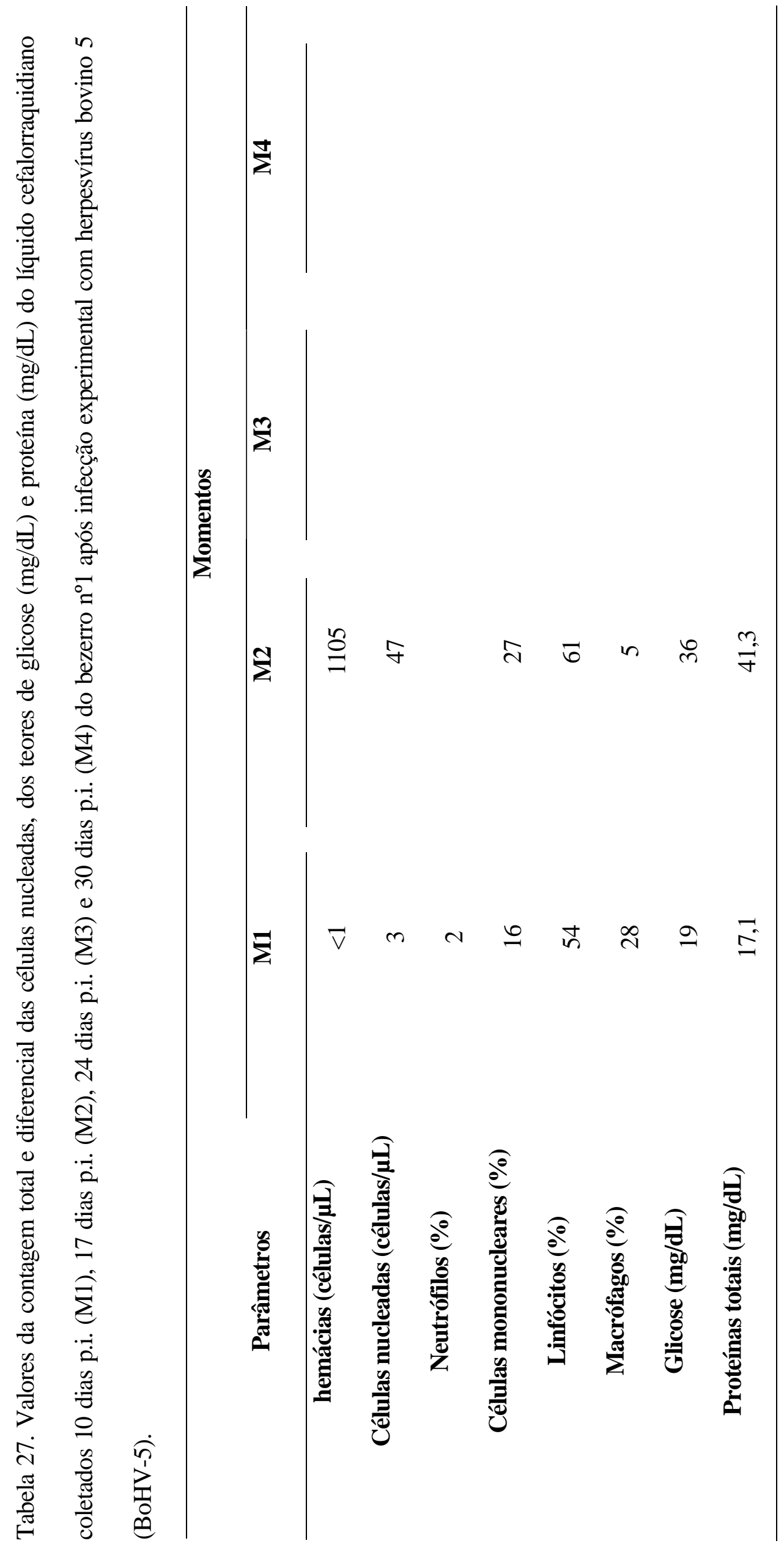




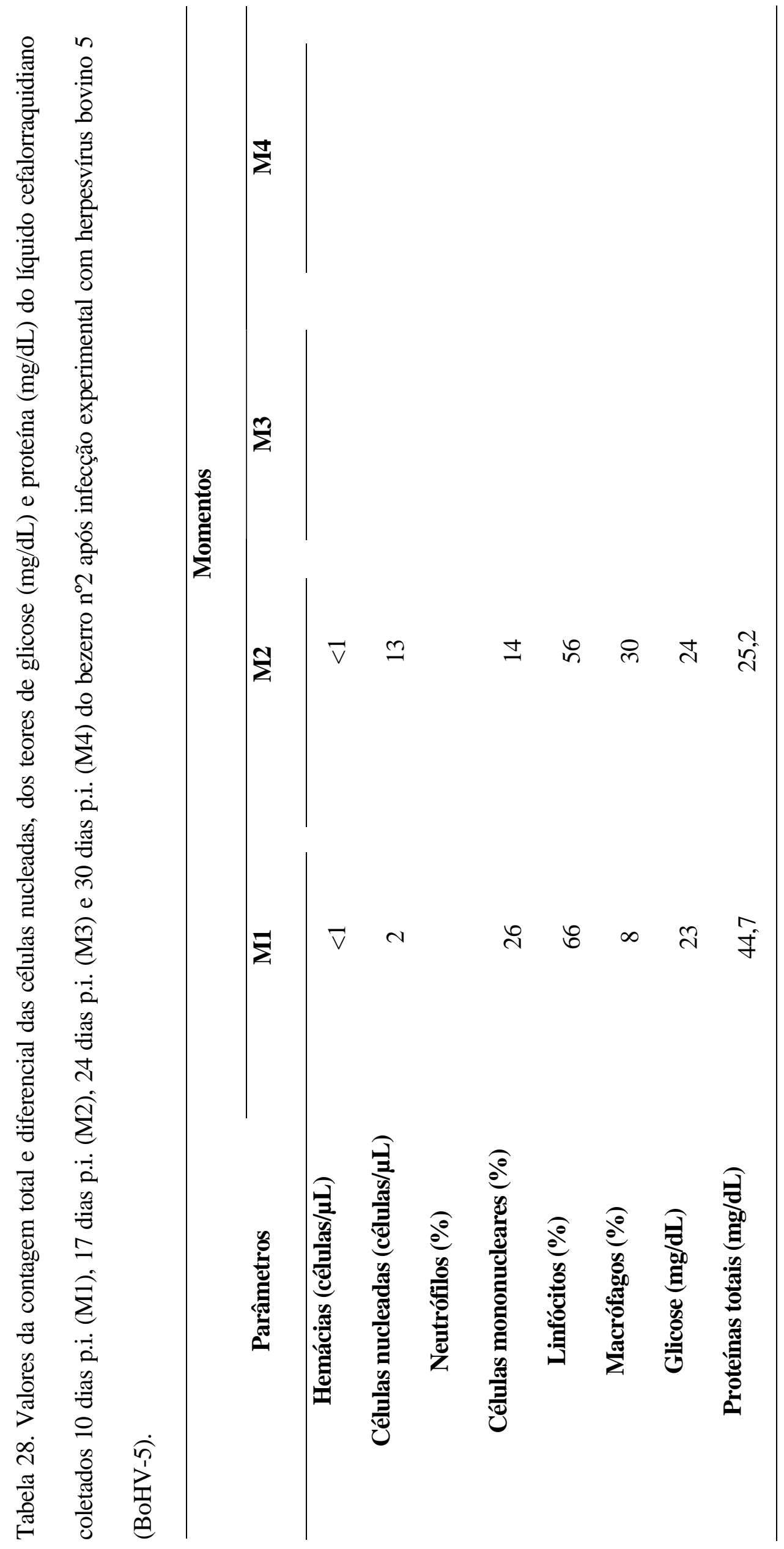




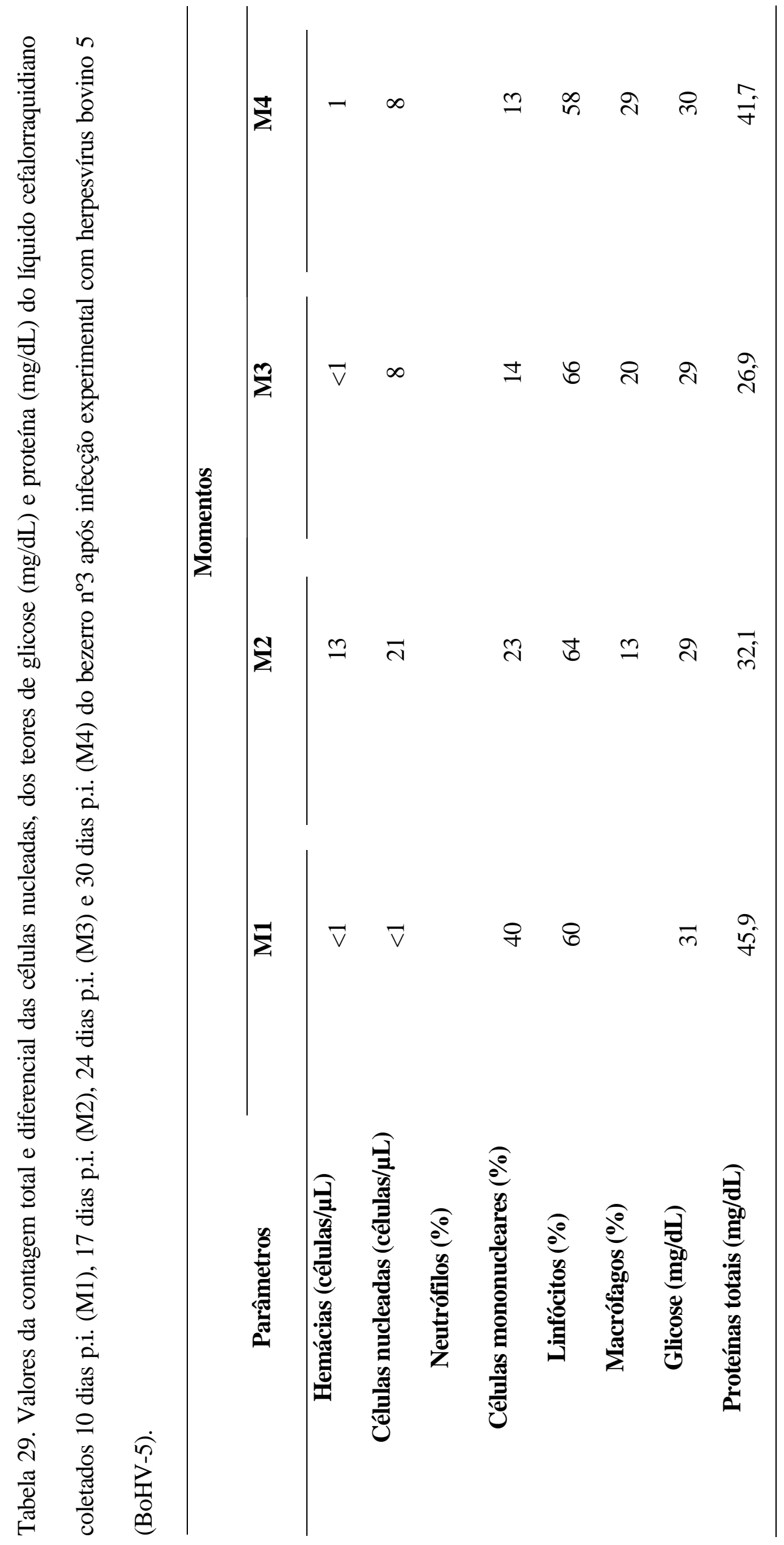




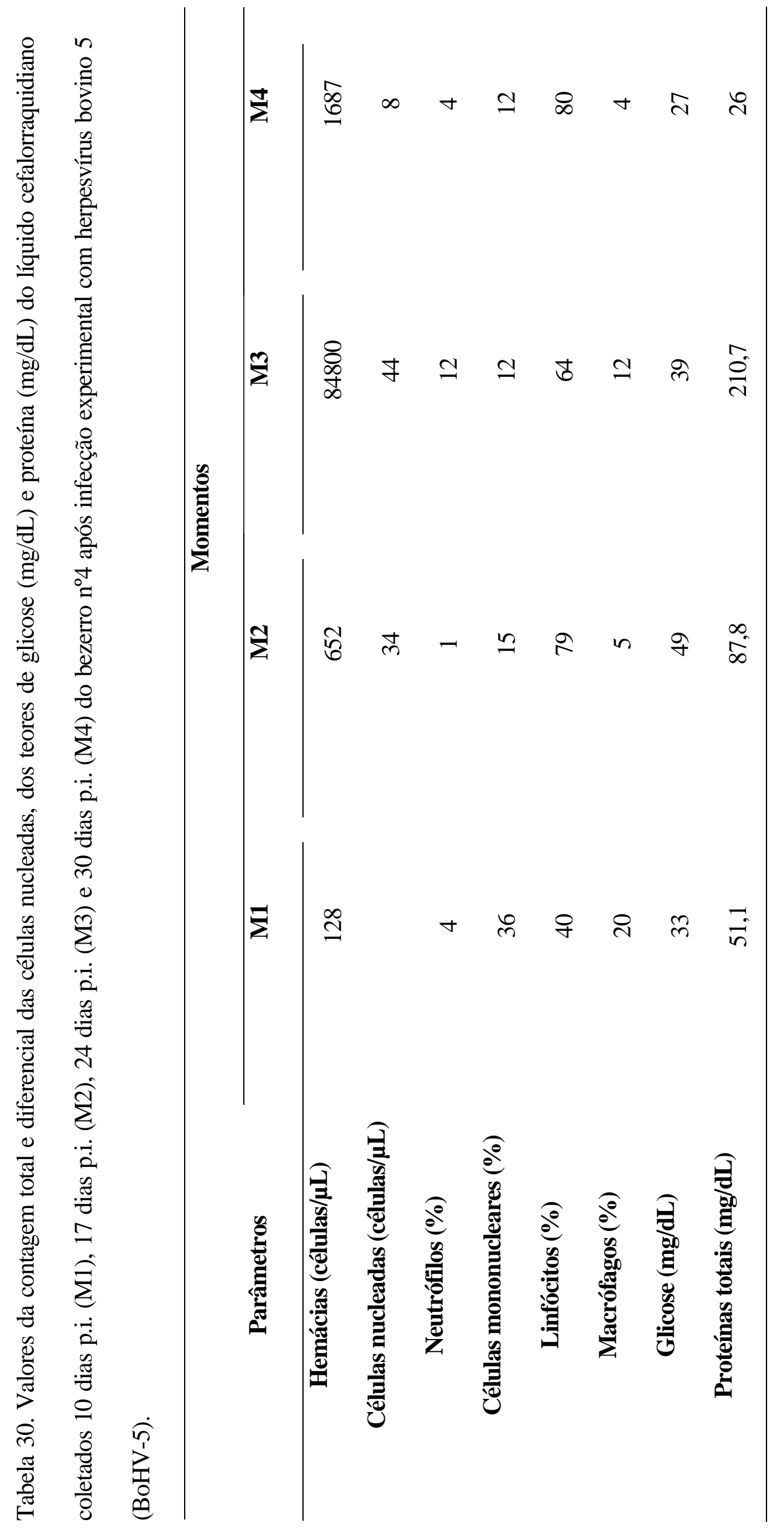




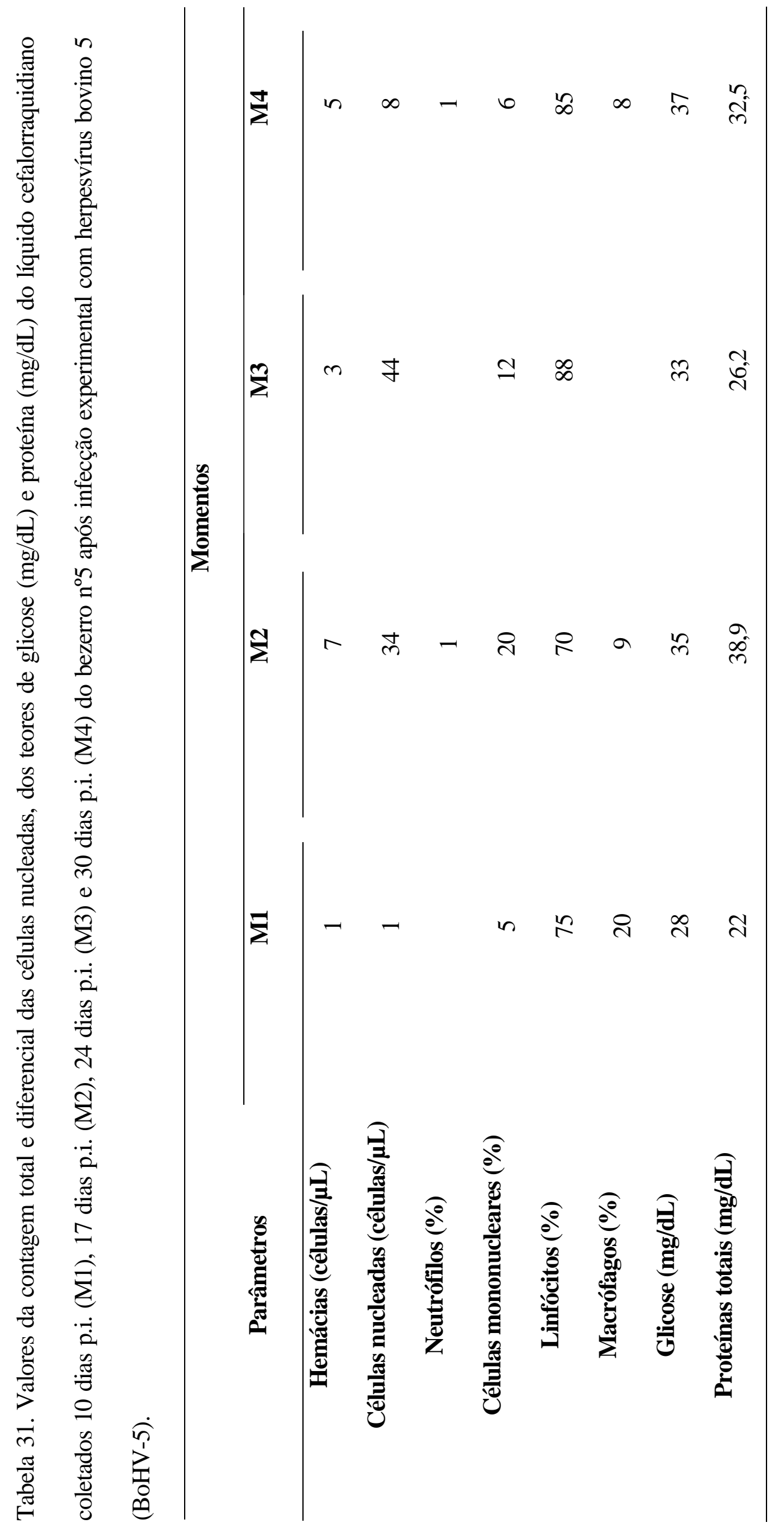




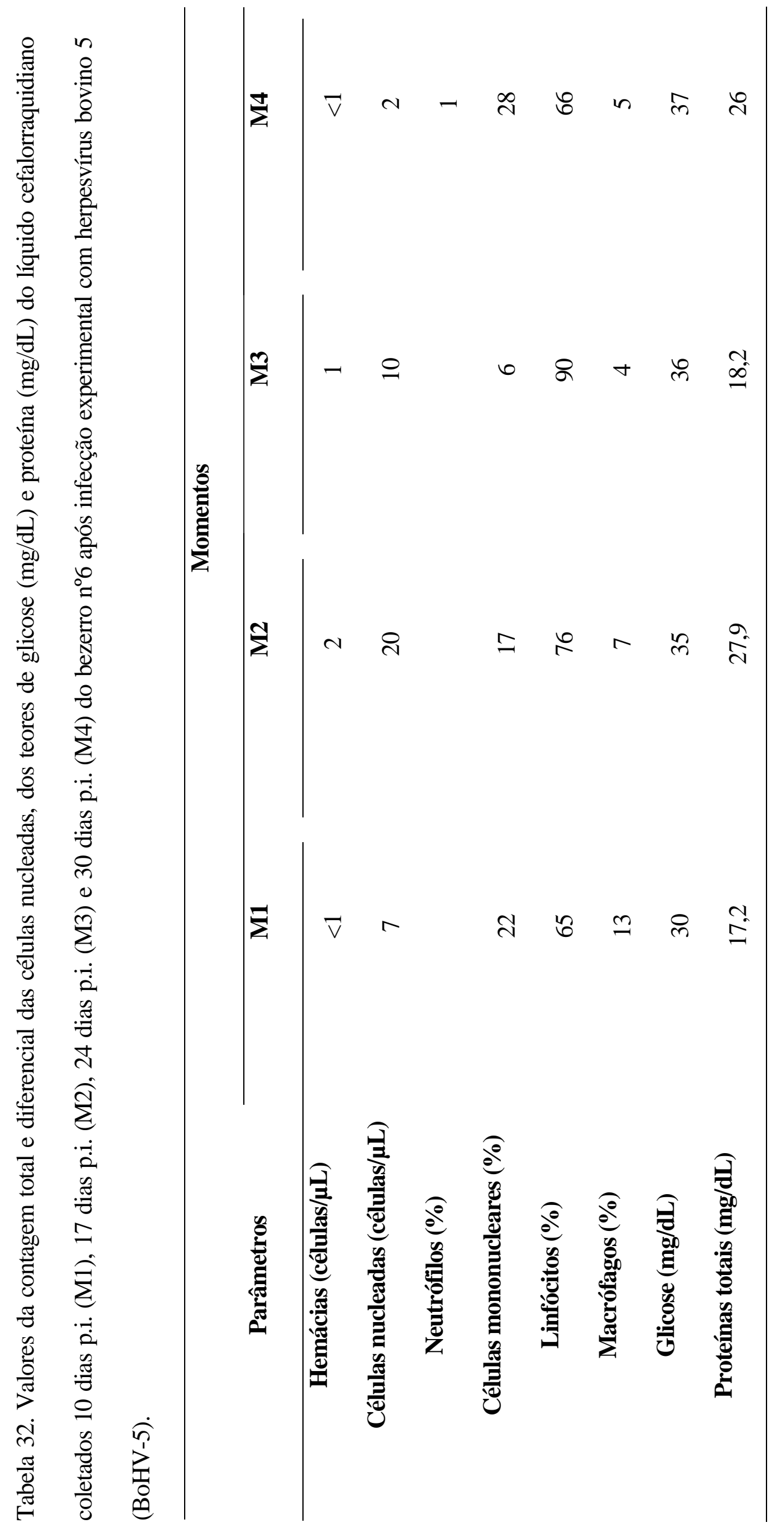




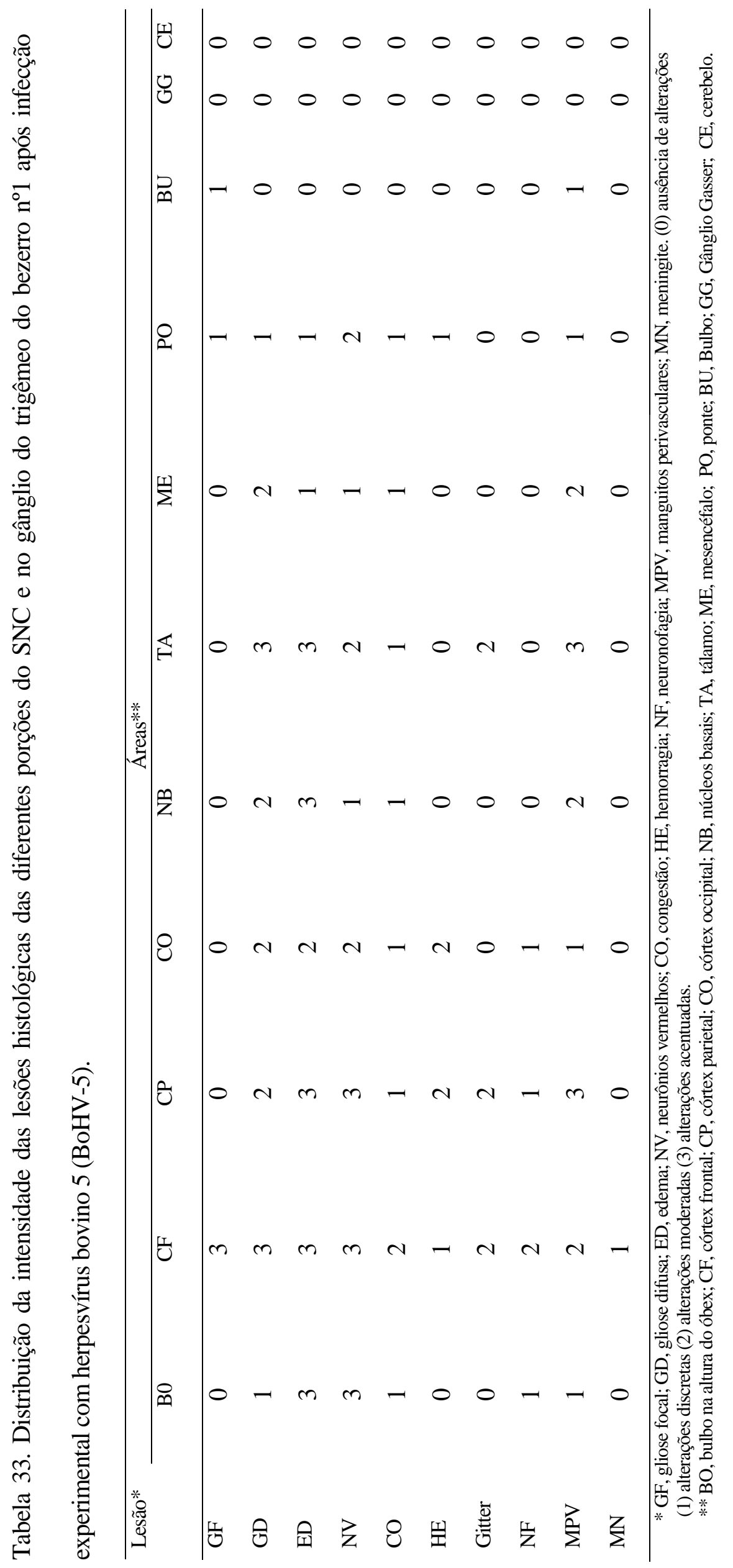




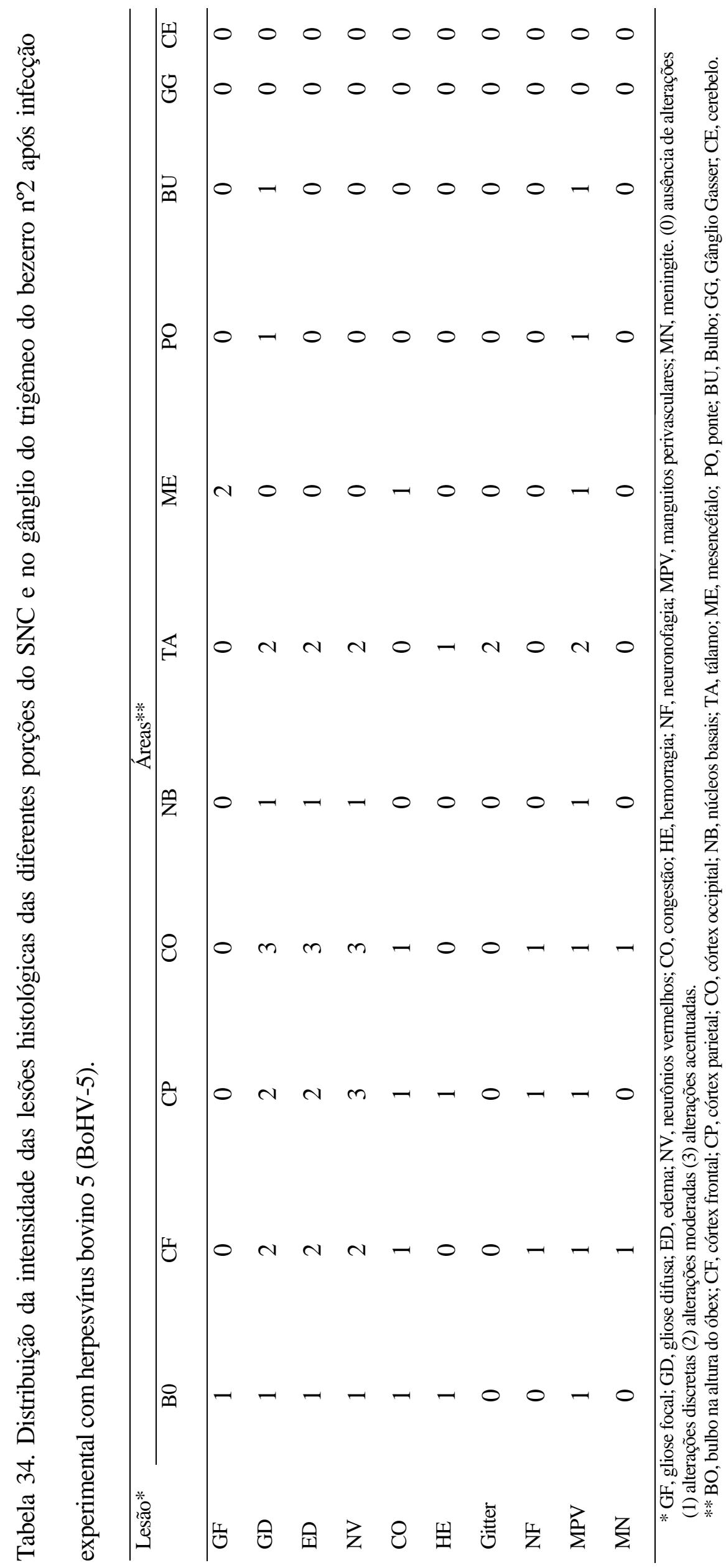




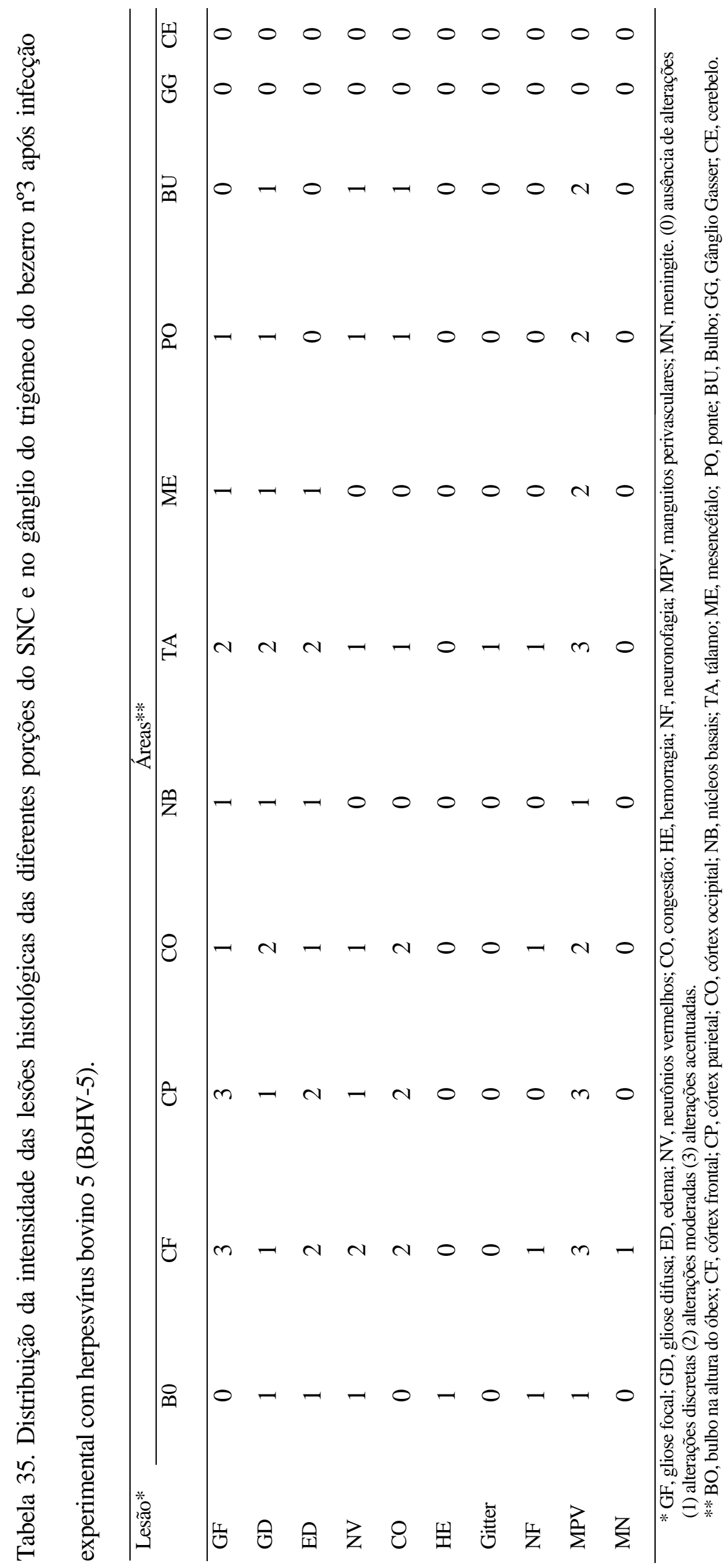




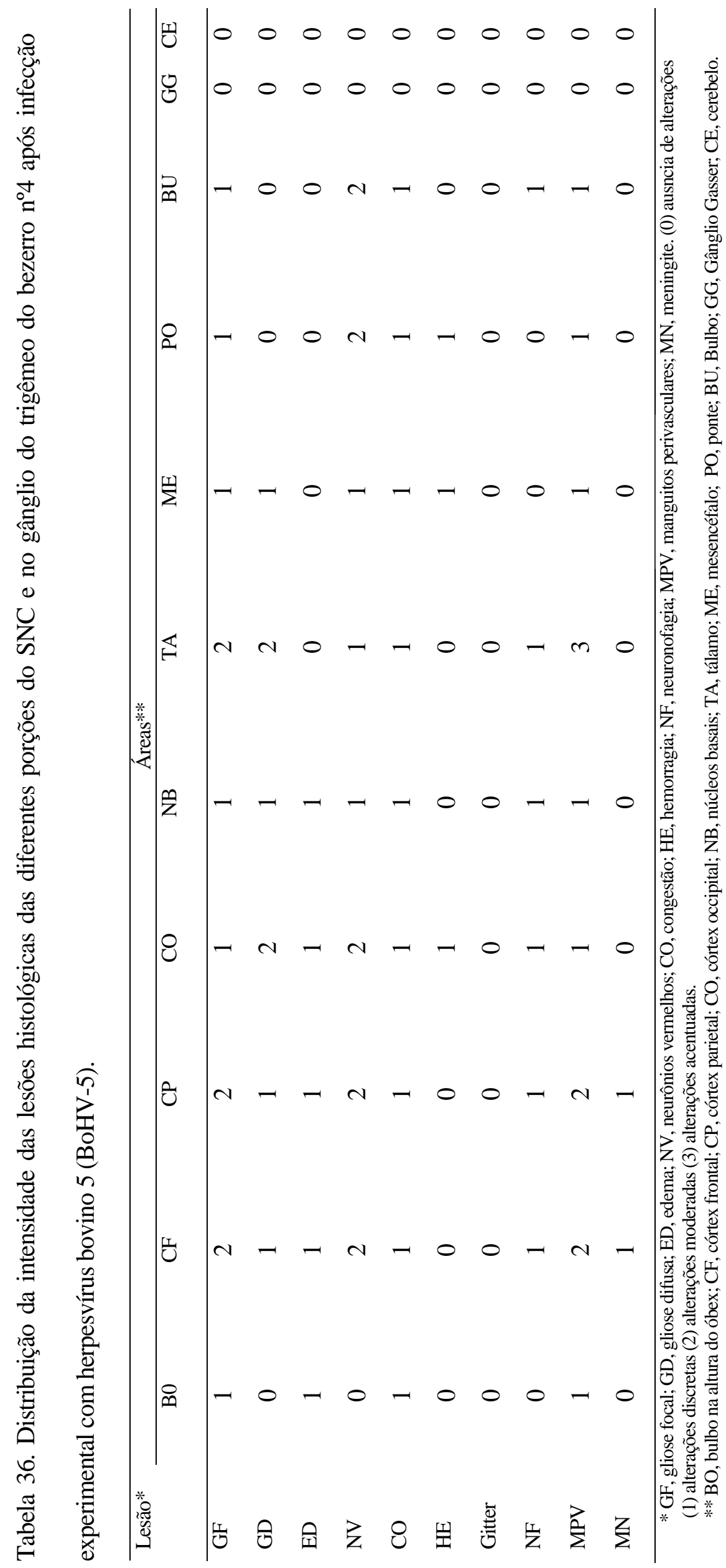




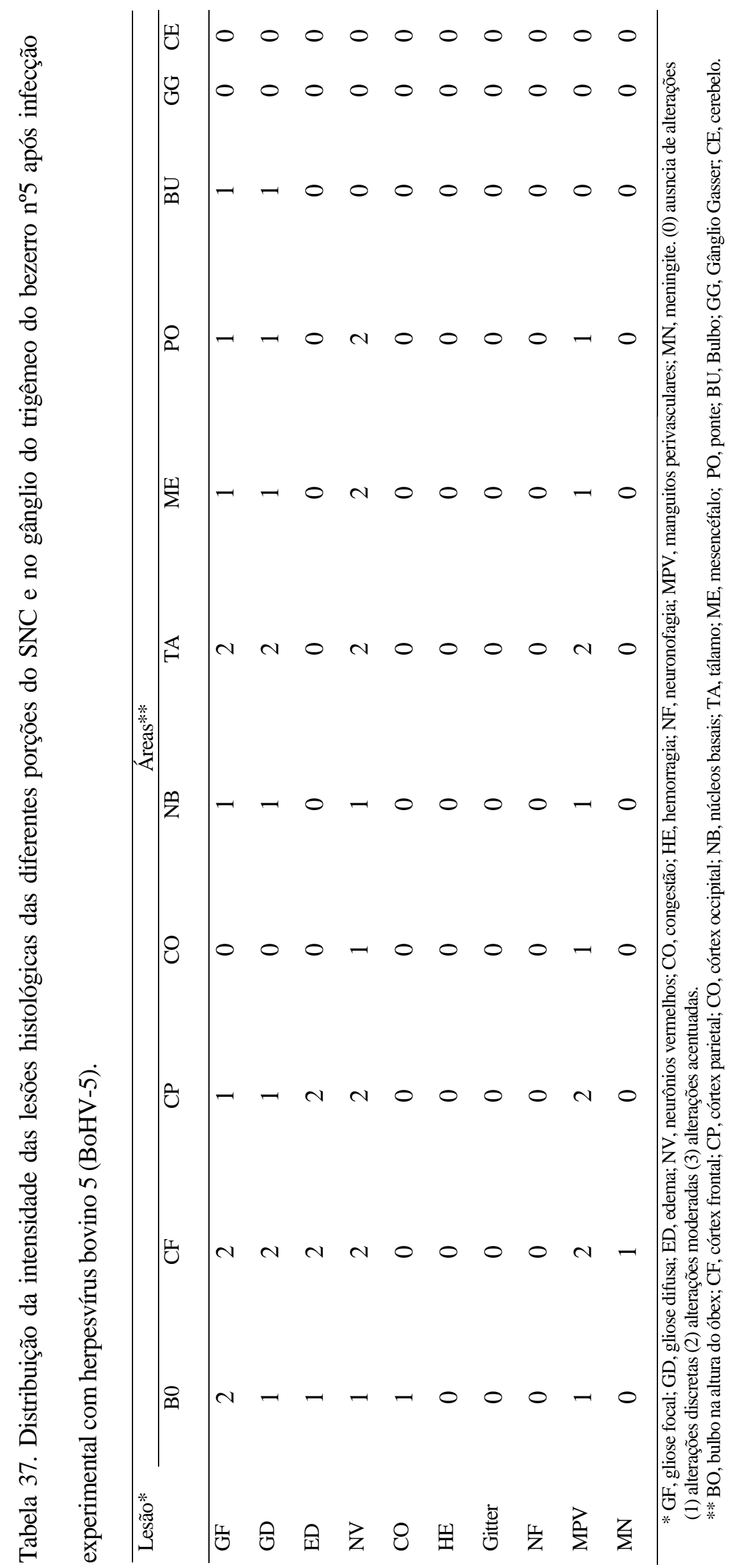




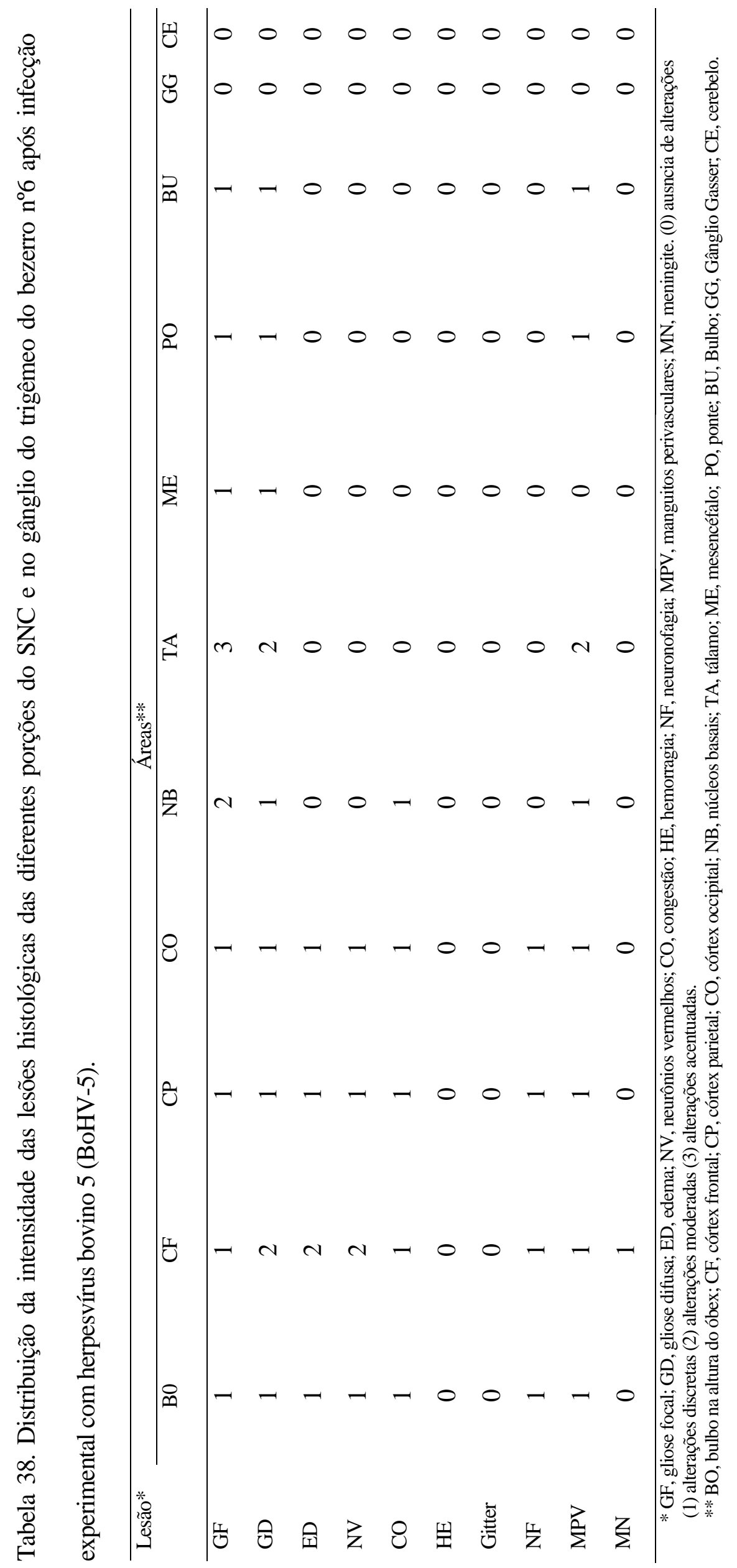


Trabalhos enviados para Revista Ciência Rural 
Avaliação da concentração do sulfeto de hidrogênio ruminal utilizando tubos colorimétricos em bovinos Nelore sadios criados extensivamente.

Evaluation of ruminal hydrogen sulfide concentration using a detector tube method in bovine kept under extensive system

Paulo Henrique Jorge da Cunha ${ }^{\mathrm{I}}$, Peres Ramos Badial ${ }^{\mathrm{II}}$, José Paes de Oliveira Filho ${ }^{\mathrm{II}}$, Didier

\section{RESUMO} excessivas de sulfeto de hidrogênio ruminal $\left(\mathrm{H}_{2} \mathrm{~S}\right)$ podendo ocasionar polioencefalomalacia nos bovinos. O presente trabalho objetivou estabelecer a concentração do sulfeto de hidrogênio ruminal utilizando tubos colorimétricos em bovinos Nelore sadios criados em pasto de Brachiaria decumbens contendo 0,15\% de enxofre na matéria seca. Quatro bovinos foram submetidos a exames físicos (temperatura retal, frequência cardíaca e respiratória e 21 motricidade ruminal) e laboratoriais (hemograma, fibrinogênio plasmático, proteínas totais, pH do fluido ruminal, prova de redução do azul de metileno e concentração de sulfeto de 23 hidrogênio ruminal), com intervalos de 96 horas, durante um período de 40 dias. Os

\footnotetext{
${ }^{\text {I }}$ Departamento de Medicina Veterinária, Escola de Veterinária da Universidade Federal de Goiás, Campus Samambaia (Campus II), Caixa postal 131, Goiânia, GO. CEP: 74001-970. *Autor para correspondência: phcunhavet@yahoo.com.br.

II Departamento de Clínica Veterinária, Faculdade de Medicina Veterinária e Zootecnia, UNESP - Campus de Botucatu, Distrito de Rubião Júnior s/n, Botucatu, SP 18618-000, Brasil.
} 
1 resultados indicaram que os bovinos permaneceram saudáveis durante o período experimental

2 e que as dosagens de sulfeto de hidrogênio ruminal foram inferiores a $100 \mathrm{ppm}$. A técnica

3 utilizando tubos colorimétricos para dosagem de sulfeto de hidrogênio ruminal foi de fácil

4 execução à campo e de baixo risco à saúde dos animais. Bovinos Nelore mantidos em pasto

5 de Brachiaria decumbens com $0,15 \%$ de enxofre na matéria seca apresentam concentração

6 máxima de 100 ppm de gás sulfídrico ruminal.

7 Palavras-chave: sulfeto de hidrogênio ruminal, bovino, Brachiaria decumbens.

\section{ABSTRACT}

Ingestion of diets with high sulfur content can produce excessive ruminal hydrogen sulfide $\left(\mathrm{H}_{2} \mathrm{~S}\right)$, which can cause bovine polioencephalomalacia. The aim of this work was to establish the concentration of ruminal hydrogen sulfide using a detector tube method in health Nelore bovine kept in Brachiaria decumbens pasture (0.15\% S dry matter). Four animals were clinically evaluated (retal temperature, cardiac and respiratory rate and ruminal motricity) and laboratorial (hematology, plasma fibrinogen, total protein, ruminal fluid $\mathrm{pH}$, reduction under methylene blue and ruminal hydrogen sulfide concentration) with 96 hour of intervals, during 40 days of experimental period. Clinical and laboratorial results indicated that animals remained healthy during the experimental period and ruminal sulfide hydrogen values were inferior to $100 \mathrm{ppm}$. According to the results, it was concluded that the technique 21 was simple, efficient and minimally invasive for estimating ruminal hydrogen sulfide under 22 field conditions and healthy Nelore bovine kept in Brachiaria decumbens pasture with sulfur content of $0.15 \%$ of dry matter presented maximum concentrations of $100 \mathrm{ppm}$ of $\mathrm{H}_{2} \mathrm{~S}$.

Key words: ruminal sulfide hydrogen, bovine, Brachiaria decumbens. 


\section{INTRODUÇÃO}

O sulfeto de hidrogênio (gás sulfídrico) é um produto normal do metabolismo da microbiota ruminal. Porém, quando os bovinos consomem dietas com alto teor de enxofre ocorre produção excessiva deste gás $\left(\mathrm{H}_{2} \mathrm{~S}\right)$ no rúmen podendo ocasionar a

6 polioencefalomalacia (PEM). A PEM é uma encefalopatia degenerativa dos ruminantes, 7 sendo o termo utilizado para descrever a alteração morfológica caracterizada por 8 amolecimento (malacia) da substância cinzenta (polio) do encéfalo (GOULD, 2000).

Pesquisas indicam que a PEM não apresenta uma etiologia única, pois vários fatores têm sido associados à sua ocorrência, tais como, alterações no metabolismo da tiamina, 11 intoxicação por chumbo, privação hídrica e/ou intoxicação por cloreto de sódio, ingestão excessiva de enxofre (GOULD, 2000), infecção pelo herpesvirus bovino tipo 5 e intoxicação por Phalaris spp. (BARROS et al., 2006).

A ingestão de altos teores de enxofre é a causa mais comum de PEM nos Estados Unidos da América (EUA) (GOULD, 2000). Contudo, no Brasil, com exceção de um relato de PEM no Rio Grande do Sul (TRAVERSO et al., 2001), as demais descrições em diversos Estados brasileiros (MS, SP, RS, MG, GO, MT, PE, PA), não estabeleceram a participação do enxofre na etiologia desta encefalopatia em bovinos a pasto (LIMA et al., 2005).

A forma mais adequada de diagnosticar a PEM causada por alto teor de enxofre é a determinação desse mineral na dieta, pasto e água, bem como a determinação da concentração

21 do gás sulfídrico ruminal. Todas estas informações associadas aos achados do exame postmortem sustentam um diagnóstico definitivo desta enfermidade (GOULD, 2000).

A determinação dos valores de $\mathrm{H}_{2} \mathrm{~S}$ ruminal utilizando tubos colorimétricos foi descrita por GOULD et al (1997) e NILES et al. (2002) nos EUA e por CUNHA et al. (2009) no Brasil, mas apenas em bovinos Bos taurus mantidos confinados. 
Os casos de PEM descritos em bovinos criados extensivamente no Brasil não tiveram

2 os valores de $\mathrm{H}_{2} \mathrm{~S}$ ruminal aferidos e não foram encontrados na literatura nacional compilada

3 valores de referência para este composto em animais criados extensivamente. Isto justifica a

4 importância deste trabalho, pois, a bovinocultura brasileira de corte é baseada na criação

5 extensiva sustentada pelas forrageiras, sobretudo a Brachiaria decumbens, além do fato de

6 que aproximadamente $80 \%$ dos bovinos criados extensivamente são da raça Nelore.

O objetivo do trabalho foi de avaliar a concentração do $\mathrm{H}_{2} \mathrm{~S}$ ruminal utilizando tubos

colorimétricos contribuindo para a determinação de valores fisiológicos deste composto em bovinos Nelore considerados sadios por exames clínicos e hematológicos e mantidos a campo, fornecendo dados técnicos para que diante de um surto de PEM em bovinos a campo seja possível comparar os valores de $\mathrm{H}_{2} \mathrm{~S}$ ruminal com os obtidos na presente pesquisa.

MATERIAL E METODOS

O experimento foi realizado em uma fazenda de gado de corte localizada no município de Paulistânia, na região centro-oeste do Estado de São Paulo, Brasil, entre os meses de janeiro a março de 2008. Foram avaliados quatro bovinos da raça Nelore com idades variando entre 15 a 20 meses e com peso vivo médio de $350 \mathrm{Kg}$, mantidos em piquete com $B$. decumbens.

As amostras do capim foram colhidas usando um quadrado de $0,25 \mathrm{~m}^{2}$, o qual foi

21 lançado aleatoriamente 10 vezes em diferentes pontos do piquete. A análise bromatológica 22 (35,85\% matéria seca; $8 \%$ proteína bruta; $2,47 \%$ extrato etéreo; 8,33\% minerais; 34,01\% fibra 23 bruta; 48,18\% extrato não nitrogenado; $60,26 \%$ nutrientes digestíveis totais; $72,79 \%$ fibra 24 detergente neutra; 39,11\% fibra detergente ácida) da pastagem foi realizada no Laboratório de 25 Bromatologia da Faculdade de Medicina Veterinária e Zootecnia da Universidade Estadual 
1 Paulista "Júlio de Mesquita Filho" (FMVZ/UNESP/Botucatu). As análises de elementos

2 minerais (13 g/ $\mathrm{kg}$ de nitrogênio, 2,9g/ $\mathrm{kg}$ de fósforo, $18 \mathrm{~g} / \mathrm{kg}$ de potássio, $3 \mathrm{~g} / \mathrm{kg}$ cálcio, 1,5

$3 \mathrm{~g} / \mathrm{kg}$ de magnésio, $1,5 \mathrm{~g} / \mathrm{kg}$ de enxofre, $6 \mathrm{mg} / \mathrm{kg}$ de boro, $10 \mathrm{mg} / \mathrm{kg}$ de cobre, $108 \mathrm{mg} / \mathrm{kg} \mathrm{de}$

4 ferro, $99 \mathrm{mg} / \mathrm{kg}$ de manganês e $58 \mathrm{mg} / \mathrm{kg}$ de zinco) do capim e a dosagem de enxofre da água

$5 \quad(0,65 \mathrm{mg} / \mathrm{L})$ do poço semi-artesiano foram realizadas, respectivamente, nos Laboratórios de

6 Nutrição Mineral de Plantas e de Fertilizantes e Corretivos da Faculdade de Ciências

7 Agronômicas da UNESP/Botucatu.

O período experimental compreendeu 40 dias, sendo que os exames físicos, as

9 colheitas de amostras de sangue, as dosagens de gás sulfídrico ruminal e as aferições do pH e

PRAM do fluido ruminal foram realizadas sempre as 9:00 horas com intervalos de 96 horas,

11 totalizando 10 diferentes momentos (M1, M2, M3, M4, M5, M6, M7, M8, M9 e M10)

12 avaliados por animal.

Os animais foram retirados do piquete de B. decumbens, localizado ao lado do local de exame e imediatamente colocados em tronco de contenção para realização do exame físico.

Em seguida, foram obtidas amostras de sangue, determinadas às concentrações do gás sulfídrico ruminal e, por último, colhido o fluido ruminal. Os exames físicos foram realizados

17 de acordo com DIRKSEN et al. (1993), sendo avaliadas e registradas a temperatura, freqüência cardíaca e respiratória e motricidade ruminal.

As amostras de sangue total foram colhidas em tubos contendo anticoagulante por venopunção da jugular e submetidas à contagem de células em câmara hematimétrica de

21 Neubauer, à determinação do volume globular pelo método do microhematócrito e à dosagem

22 de hemoglobina pelo método da cianometahemoglobina, calculando-se posteriormente os 23 índices hematimétricos (volume globular médio e concentração de hemoglobina globular 24 média) (COLES, 1984). A contagem diferencial de leucócitos foi realizada em 100 células em 25 esfregaços sanguíneos corados pelo Panótico Rápido. Para mensuração do fibrinogênio 
1 utilizou-se a técnica de precipitação no tubo de microhematócrito a $56^{\circ} \mathrm{C}$, enquanto a proteína

2 total foi determinada diretamente pela refratometria (COLES, 1984).

A técnica utilizada para a determinação da concentração de gás sulfídrico ruminal foi adaptada de GOULD et al. (1997) com as modificações descritas por CUNHA et al (2009). Inicialmente foi realizada a tricotomia da fossa paralombar esquerda e anti-sepsia com

6 iodopovidona (PVPI). A punção ruminal foi realizada no ponto médio da porção mais dorsal 7 da fossa paralombar esquerda utilizando-se agulha do cateter intravenoso $14 \mathrm{G}$ sem a cânula externa de teflon. Em seguida, foi encaixado ao conector da agulha um equipo intravenoso com $15 \mathrm{~cm}$ de comprimento, cortando e desprezando-se a extremidade com o gotejador. A ponta cortada do equipo adaptado foi acoplada ao tubo colorimétrico de dosagem de gás

11 sulfídrico ${ }^{\mathrm{a}}$, que já estava previamente inserido na bomba manual de vácuo ${ }^{\mathrm{b}}$. As mensurações 12 foram realizadas de acordo com o manual do fabricante da bomba de vácuo, padronizando em $13100 \mathrm{~mL}$ de gás para valores entre 25 a 1000 ppm de sulfeto de hidrogênio com tempo de 14 amostragem de 1,5 minutos. Nos momentos em que não ocorreu mudança na coloração do 15 tubo, repetiu-se a dosagem e não detectando alteração foi estabelecido que o valor aferido 16 estivesse abaixo do limite inferior de detecção do tubo ( $<25 \mathrm{ppm}$ de $\mathrm{H}_{2} \mathrm{~S}$ ruminal).

O liquido ruminal foi coletado utilizando-se uma sonda acoplada a uma bomba de vácuo e os primeiros $200 \mathrm{ml}$ foram desprezados com o intuito de minimizar o efeito alcalinizante da saliva sobre o $\mathrm{pH}$. As análises realizadas no líquido ruminal foram: $\mathrm{pH}$ e a prova de redução do azul de metileno (PRAM) segundo protocolo proposto por DIRKSEN et 21 al. (1993).

Os resultados foram submetidos à análise descritiva, constituída pelo cálculo das médias aritméticas e dos desvios-padrão (SAMPAIO, 1998). 
Os valores médios e desvios-padrão da temperatura corpórea $\left(38,9 \pm 0,09^{\circ} \mathrm{C}\right)$, freqüência cardíaca $(71,56 \pm 4,87$ batimentos/minuto $)$ e respiratória $(27,38 \pm 3,16$

4 movimentos/minuto) permaneceram dentro da faixa de normalidade para a espécie bovina 5 (RADOSTITS et al., 2002) em todos os momentos avaliados.

A motricidade ruminal apresentou valores médios que variaram de 3,6 a 8,2 movimentos ruminais em cinco minutos. DIRKSEN et al. (1993) estabeleceu como valores normais para bovinos Bos taurus de sete a dez movimentos em cinco minutos, ou seja, valores superiores aos encontrados nos zebuínos avaliados. Entretanto, em nenhum animal foi identificado sinal clínico sugestivo de doença do trato digestório, não sendo observado 11 alterações na postura, no comportamento, na forma abdominal e nos ruídos ruminais a auscultação (RADOSTITS et al., 2002).

Os resultados dos valores médios e desvios-padrão obtidos dos constituintes dos

14 eritrogramas dos animais (Tabela 1) permaneceram dentro de um intervalo de normalidade (AYRES, 1994), exceto para o bovino $\mathrm{n}^{\circ} .1100$. Analisando os dados dos eritrogramas desse animal constatou-se uma discreta anemia normocítica normocrômica nos resultados da segunda, terceira e quarta colheitas (dados não apresentados). Nas colheitas subsequentes não foi verificado qualquer tipo de alteração no eritrograma, corroborando com JAIN (1993) de que este tipo de anemia raramente é severo o suficiente para requerer tratamento.

Os resultados dos valores médios dos constituintes dos leucogramas e as

21 determinações dos fibrinogênios e proteínas totais (Tabela 1) dos quatro bovinos encontram22 se todos dentro do intervalo de normalidade para a espécie (RADOSTITS et al., 2002), 23 indicando que durante o período experimental os bovinos se mantiveram saudáveis. Em relação ao consumo de enxofre pelos bovinos Nelore, considerou-se que a ingestão da forragem foi de $2,5 \%$ do peso vivo representando uma ingestão de $0,15 \%$ de 
1 enxofre na matéria seca. Para o cálculo da ingestão de enxofre na água foi estimado que um

2 bovino de $350 \mathrm{Kg}$ mantido em temperatura ambiente de $28^{\circ} \mathrm{C}$ deve ingerir 37 litros de água 3 por dia (GOULD, 2000), totalizando um consumo de $24 \mathrm{mg}$ de enxofre por dia $(0,0024 \%$ de

4 enxofre na matéria seca), visto que a concentração de enxofre obtida na água foi de $0,65 \mathrm{mg} / \mathrm{L}$.

5 Assim, os bovinos ingeriram um total de $0,1524 \%$ de enxofre na matéria seca, estando no

6 nível recomendado $(0,15 \%)$ pelo NRC (2005).

GOULD et al (1997) ao compararam à técnica da dosagem de gás sulfídrico ruminal utilizando tubos colorimétricos com a cromatografia líquida de alta eficiência, não observaram diferenças significativas entre os resultados obtidos, confirmando que a metodologia empregada no presente estudo reflete valores confiáveis da concentração de $\mathrm{H}_{2} \mathrm{~S}$ 11 ruminal, sendo desnecessário o uso de outras técnicas para este propósito. A dosagem de gás 12 sulfídrico ruminal, estabelecida por GOULD et al (1997) e adaptada por CUNHA et al (2009) realizada na presente pesquisa, caracterizou-se como um exame complementar prático porque pode ser realizada a campo e fornece de forma imediata uma estimativa da concentração do sulfeto de hidrogênio ruminal. Outro aspecto importante desta metodologia de dosagem de $\mathrm{H}_{2} \mathrm{~S}$ ruminal com uso de tubos colorimétricos é a segurança da técnica visto que mesmo após terem sido realizadas dez punções ruminais com intervalos de 96 horas em cada animal, não foram observadas alterações nos resultados do leucograma e do fibrinogênio plasmático que indicassem inflamação. Segundo JAIN (1993) o nível de fibrinogênio plasmático é o melhor indicador de 21 doença inflamatória nos bovinos, sendo superior à avaliação do quadro leucocitário. Os valores detectados do gás sulfídrico ruminal foram inferiores a 100 ppm (Tabela 2).

23 Não foram encontrados na literatura nacional valores de referência para este composto em 24 bovinos Nelore criados extensivamente utilizando metodologia empregada neste estudo. 25 GOULD et al. (1997) e NILES et al. (2002) utilizaram metodologia semelhante de dosagem 
1 de $\mathrm{H}_{2} \mathrm{~S}$ ruminal e consideraram como valores normais para o $\mathrm{H}_{2} \mathrm{~S}$ ruminal concentrações

2 inferiores a $500 \mathrm{ppm}$. Entretanto, este valor foi estabelecido por GOULD et al. (1997) a partir

3 de mensurações realizadas em bezerros da raça Holandesa alimentados com feno de alfafa e 4 mantidos confinados.

Na tabela 3 são apresentados os valores médios do pH e PRAM ruminais avaliados

6 durante o período experimental. Os valores do PRAM esperados sob condições normais devem ser de 3 a 6 minutos (OLIVEIRA, 1991), sendo que os resultados indicaram uma boa atividade da microflora ruminal, pois, o tempo médio foi de aproximadamente três minutos. No presente trabalho, o $\mathrm{pH}$ esteve em acordo com os valores fisiológicos para dietas com alto conteúdo de fibra, variando entre 6,5 a 7,5 (CAMPOS et al., 2006). Uma microbiota ruminal ativa e um $\mathrm{pH}$ perto da perto da neutralidade garantem um processo digestivo dinâmico e uma geração de ácidos graxos e síntese de proteína microbiana adequada (VAN SOEST, 1994). No rúmen, os íons sulfeto são encontrados principalmente na fase gasosa como sulfeto de hidrogênio (gás sulfídrico) e na líquida como ânion hidro-sulfeto, sendo que o pH ruminal influência a proporção da distribuição entre estas duas formas (GOULD, 2000). Assim, um dos fatores que pode ter favorecido a produção de gás sulfídrico ruminal inferior a 100 ppm pelos bovinos Nelore avaliados foi o $\mathrm{pH}$ do rúmen superior a 6,5 , porque $\mathrm{pH}$ ruminal próximo a 7 proporciona concentrações de $\mathrm{H}_{2} \mathrm{~S}$ ruminal inferiores a 500 ppm (GOULD, 2000).

A técnica de dosagem de sulfeto de hidrogênio ruminal pelos tubos colorimétricos é uma ferramenta útil para monitorar situações de risco e auxiliar no diagnóstico definitivo da PEM por enxofre. A utilização desta metodologia associada à análise de enxofre na dieta, pastos, água e suplementos (GOULD, 2000) estabeleceriam a participação do enxofre nos casos de PEM no Brasil (LIMA et al., 2005), bem como auxiliaria no diagnóstico diferencial de outras causas de encefalopatias (BARROS et al., 2006). 


\section{CONCLUSÃO}

De acordo com os resultados, pode-se concluir que a técnica para dosagem de sulfeto de hidrogênio ruminal utilizando tubos colorimétricos foi de fácil execução à campo e de baixo risco à saúde dos animais. Bovinos Nelore mantidos em pasto de Brachiaria decumbens com $0,15 \%$ de enxofre na matéria seca apresentam concentração máxima de 100 ppm de gás sulfídrico ruminal.

\section{AGRADECIMENTOS}

À CAPES pela bolsa PICDT de doutorado concedida ao primeiro autor. Ao CNPq pela bolsa de produtividade ao último autor e a FAPESP (2006/05836-6) pelo apoio financeiro.

\section{FONTES DE AQUISIÇÃO}

b - Bomba modelo AP-20S - Sensidyne ${ }^{\circledR}$ - Florida - USA.

\section{COMITÊ DE ÉTICA E BIOSSEGURANÇA}

Todos os procedimentos realizados encontram-se de acordo com as normas e princípios éticos de experimentação animal, estabelecidos pela Câmara de Ética em Experimentação Animal da FMVZ/UNESP/Botucatu (Protocolo n¹17/2006-CEEA). 


\section{REFERÊNCIAS}

AYRES, M.C.C. Eritrograma de zebuínos (Bos Indicus), Linnaeus, 1758) da raça Nelore, criados no Estado de São Paulo: Influência de fatores etários, sexuais e do tipo racial. 1994.141f. Dissertação - Curso de Pós-graduação em Clínica Veterinária, Universidade de

7 São Paulo.

BARROS, C.S.L. et al. Polioencefalomalacia (necrose cerebrocortical). In: Doenças do sistema nervoso de bovinos no Brasil. 1.ed. Montes Claros, MG: Vallée, 2006. Cap.33, p.166-171.

CAMPOS, R. et al. Indicadores do ambiente ruminal e suas relações com a composição do

12 leite e células somáticas em diferentes períodos da primeira fase da lactação em vacas de alta 13 produção. Ciência Rural, 36, n.2, p.525-530, 2006. Disponível em: < 14 http://www.scielo.br/pdf/cr/v36n2/a25v36n2.pdf> Acesso em 26 ago. 2009 . doi: $15 \quad 10.1590 / \mathrm{S} 0103-84782006000200025$.

16 COLES, E.H. Patologia Clínica Veterinária. 3.ed. São Paulo: Manole, 1984. 566p.

17 CUNHA, P.H.J. et al. Indução de necrose cerebrocortical em bezerros com dieta rica em 18 enxofre. In: CONGRESSO BRASILEIRO DE BUIATRIA, 8, Anais... Belo Horizonte, 2009. 19 (in press).

20 DIRKSEN, G. et al. Exame clínico dos bovinos. 3.ed. Rio de Janeiro: Guanabara Koogan, $21 \quad 1993,419 \mathrm{p}$.

22 GOULD, D.H. et al. In vivo indicators of pathologic ruminal sulfide production in steers with 23 diet-induced polioencephalomalacia. Journal of Veterinary Diagnostic, n.9, p.72-76, 1997.

24 Disponível em: <http://jvdi.org/cgi/reprint/9/1/72>. Acesso em: 20 jul. 2009. 
1 GOULD, D.H. Update on sulfur-related polioencephalomalacia. In: OSWEILER, G. D.;

2 GALEY, F.D. The Veterinary Clinics of North America: Food Animal Practice, 2000,

3 v.16, n. 3, p.481-496

4 JAIN, N.C. Essentials of veterinary hematology. Philadelphia: Lea \& Febiger, 1993.417p.

5 LIMA, E.F. et al. Polioencefalomalacia em caprinos e ovinos na região semi-árida do

6 Nordeste do Brasil. Pesquisa Veterinária Brasileira, v.25, n.1, p.9-14, 2005. Disponível em:

7 <http://www.scielo.br/pdf/pvb/v25n1/23866.pdf>. Acesso em 21 jul. 2009. doi:

$8 \quad 10.1590 / \mathrm{S} 0100-736 \mathrm{X} 2005000100003$

9 NILES, G.A. et al. Effects of dietary sulfur concentrations on the incidence and pathology of

10 polioencephalomalacia in weaned beef calves. Veterinary \& Human Toxicology, v.44, n.2, 11 p.70-72, 2002.

12 NATIONAL RESEARCH COUNCIL. Mineral Tolerance of Animals. 2.ed. Washington, 13 DC: National Academy of Sciences, 2005. 385p.

OLIVEIRA, D.B. Estudo do suco ruminal de bovinos criados em regime extensivo de pastagens (Brachiaria decumbens) no município de Botucatu. 1991. 42f. Dissertação -

16 Curso de Pós-graduacao em Clinica Veterinária, FMVZ/UNESP/Botucatu.

17 RADOSTITS, O.M. et al. Clinica Veterinária: um tratado de doenças dos bovinos, suínos, caprinos e equiinos. 9.ed. Rio de Janeiro: Editora Guanabara Koogan, 2002.1890p. SAMPAIO, I.B.M. Estatística Aplicada à Experimentação Animal. Belo Horizonte: UFMG, 1998. 221p.

21 TRAVERSO, S.D. Polioencefalomalacia em bovinos leiteiros no Rio Grande do Sul 22 suplementados com enxofre. In: ENCONTRO NACIONAL DE PATOLOGIA 23 VETERINÁRIA, 10, Anais... Pirassununga, 2001. p.72.

24 VAN SOEST, P.J. Nutrition ecology of the ruminant. Salem, O. R.: O \& B Books, 1994. $25485 \mathrm{p}$. 
1 Tabela 1. Valores médios e desvios-padrão do hemograma, fibrinogênio plasmático (mg/dL) e

2 proteínas totais $(\mathrm{g} / \mathrm{dL})$ dos quatro bovinos Nelore mantidos em pasto de Brachiaria

3 decumbens durante os 40 dias de período experimental.

4

\begin{tabular}{|c|c|c|c|c|}
\hline \multirow[b]{2}{*}{ Leucograma } & \multicolumn{4}{|c|}{ Animais } \\
\hline & 1001 & 1028 & 1070 & 1100 \\
\hline Hemácias $(\times 10 \% / \mu L)$ & $6,84 \pm 0,90$ & $7,42 \pm 0,84$ & $6,44 \pm 0,52$ & $5,7 \pm 0,41$ \\
\hline Hemoglobina (mg/dL) & $10 \pm 1,41$ & $10,67 \pm 1,09$ & $9,32 \pm 0,67$ & $7,69 \pm 0,70$ \\
\hline Volume Globular (\%) & $30,35 \pm 3,72$ & $32,2 \pm 3,32$ & $27,95 \pm 1,70$ & $24,15 \pm 20$ \\
\hline VGM (fL) & $44,6 \pm 4,60$ & $43,44 \pm 2,10$ & $43,38 \pm 2,48$ & $42,44 \pm 1,93$ \\
\hline CHGM (\%) & $33,18 \pm 1,43$ & $33,13 \pm 0,85$ & $33,35 \pm 0,99$ & $31,97 \pm 1,08$ \\
\hline Leucócitos $(\mathbf{x 1 0} / \mu \mathrm{L})$ & $7,5 \pm 2,58$ & $8,148 \pm 0,65$ & $9,28 \pm 1,41$ & $9,014 \pm 1,10$ \\
\hline Segmentados $\left(\times 10^{3} / \mu L\right)$ & $2,06 \pm 1,01$ & $1,57 \pm 0,51$ & $2,77 \pm 1,84$ & $1,55 \pm 0,74$ \\
\hline Linfócitos $\left(\times 10^{3} / \mu \mathrm{L}\right)$ & $5,855 \pm 1,37$ & $6,04 \pm 0,79$ & $5,66 \pm 0,96$ & $6,54 \pm 0,74$ \\
\hline Eosinófilos $\left(\times 10^{3} / \mu \mathrm{L}\right)$ & $0,29 \pm 0,28$ & $0,15 \pm 0,18$ & $0,32 \pm 0,26$ & $0,68 \pm 0,54$ \\
\hline Basófilos $\left(\times 10^{3} / \mu \mathrm{L}\right)$ & $0,02 \pm 0,04$ & 0 & $0,02 \pm 0,05$ & $0,01 \pm 0,03$ \\
\hline Monócitos $\left(\mathbf{x} 10^{3} / \mu \mathrm{L}\right)$ & $0,39 \pm 0,30$ & $0,33 \pm 0,21$ & $0,48 \pm 0,32$ & $0,19 \pm 0,13$ \\
\hline \multicolumn{5}{|l|}{ Fibrinogênio } \\
\hline plasmático (mg/dL) & $315 \pm 110,67$ & $365 \pm 120,30$ & $375 \pm 108,65$ & $325 \pm 123,04$ \\
\hline Proteínas totais (g/dL) & $6,57 \pm 0,27$ & $6,66 \pm 0,50$ & $6,41 \pm 0,32$ & $6,7 \pm 0,27$ \\
\hline
\end{tabular}

5

6

7

8 
1 Tabela 2. Valores do sulfeto de hidrogênio ruminal em ppm, obtidos em 10 momentos, com

2 intervalos de 96 horas, em quatro bovinos Nelore mantidos em pasto de Brachiaria 3 decumbens durante período de 40 dias.

\begin{tabular}{c|cccc}
\hline \multirow{2}{*}{ Momentos } & \multicolumn{4}{|c}{ Animais } \\
\cline { 2 - 4 } M1 & $\mathbf{1 0 0 1}$ & $\mathbf{1 0 2 8}$ & $\mathbf{1 0 7 0}$ & $\mathbf{1 1 0 0}$ \\
M2 & 25 & 30 & 30 & 25 \\
M3 & 25 & 30 & 30 & 30 \\
M4 & 30 & 35 & $<25$ & $<25$ \\
M5 & $<25$ & $<25$ & 35 \\
M6 & $<25$ & $<25$ & 100 & 35 \\
M7 & $<25$ & 30 & 60 & 30 \\
M8 & $<25$ & $<25$ & 100 & 50 \\
M9 & $<25$ & $<25$ & 50 & 35 \\
M10 & 25 & $<25$ & 35 & 30 \\
\hline
\end{tabular}

4

5

6

7

8

9

10

11

12

13 
1 Tabela 3. Valores médios e desvios-padrão do pH ruminal e da prova de redução de azul de

2 metileno (minutos) dos quatro bovinos Nelore mantidos em pasto de Brachiaria decumbens 3 durante os 40 dias de período experimental.

4

\begin{tabular}{c|cccc}
\hline & \multicolumn{4}{|c}{ Animais } \\
\cline { 2 - 5 } & $\mathbf{1 0 0 1}$ & $\mathbf{1 0 2 8}$ & $\mathbf{1 0 7 0}$ & $\mathbf{1 1 0 0}$ \\
\hline pH ruminal & $6,81 \pm 0,19$ & $6,97 \pm 0,42$ & $6,87 \pm 0,34$ & $7,05 \pm 0,32$ \\
Prova redução do azul de & & & & \\
metileno (minutos) & $3,5 \pm 1,50$ & $3,5 \pm 1,90$ & $3,6 \pm 1,57$ & $5,2 \pm 1,68$ \\
\hline
\end{tabular}

5 


\title{
Comparison of cerebrospinal fluid cytological and biochemical values of healthy cattle
} (1)

\author{
in two different sampling times
} 8 Danielle Passarelli ${ }^{\text {II }}$, Regina Kiomi Takahira ${ }^{\text {II }}$, Júlio Augusto Naylor Lisboa ${ }^{\mathrm{III}}$, Alexandre Secorun Borges ${ }^{\text {II }}$

\section{RESUMO}

A análise do líquido cefalorraquidiano (LCR) é importante no diagnóstico das doenças neurológicas dos bovinos. O objetivo do presente trabalho foi verificar se existem diferenças na análise citológica e bioquímica no LCR de bovinos sadios obtidos em dois diferentes momentos com intervalo de 96 horas. O LCR foi submetido à contagem total e diferencial das células nucleadas e a determinação dos teores de proteína e glicose. Verificou-se na segunda coleta pleocitose com alteração do tipo celular predominante e elevação das proteínas

21 indicando que a coleta de LCR ocasionou inflamação local detectável 96 horas após a 22 realização da primeira punção.

\footnotetext{
I Departamento de Medicina Veterinária, Escola de Veterinária da Universidade Federal de Goiás, Campus Samambaia (Campus II), Caixa postal 131, Goiânia, GO. CEP: 74001-970. *Autor para correspondência: phcunhavet@yahoo.com.br.

II Departamento de Clínica Veterinária, Faculdade de Medicina Veterinária e Zootecnia, UNESP - Campus de Botucatu, Distrito de Rubião Júnior s/n, Botucatu, SP 18618-000, Brasil.

${ }^{\text {III }}$ Departamento de Clínicas Veterinárias, Centro de Ciências Agrárias, Universidade Estadual de Londrina, Campus Universitário Cx. Postal 6001 CEP: 86051-990 Londrina - PR, Brasil.
} 
1 Palavras-chave: líquido cefalorraquidiano, bovino, inflamação.

\section{ABSTRACT}

4 The analysis of cerebrospinal fluid (CSF) is important to the diagnosis of the neurological

5 diseases in cattle. The present study aimed to verify if there were differences on cytological

6 and biochemical examination of CSF obtained from healthy cattle at two different sampling 7 times with 96 hours of interval. Total and different cells counts, glucose and protein 8 concentrations were analyzed in the CSF. It was possible to verify pleocytosis with 9 predominant cell type modification and increased protein levels in the second sample, which 10 indicated that CSF collection induced local inflammation detectable 96 hours after the first 11 puncture.

12 Key words: cerebrospinal fluid, bovine, inflammation.

\section{INTRODUÇÃO}

A análise do líquido cefalorraquidiano (LCR) é um exame complementar útil e rápido para o diagnóstico etiológico das doenças do sistema nervoso central (SNC). A contagem total e diferencial das células e a concentração de proteína podem fornecer informações para detecção de alterações inflamatórias, confirmando que existe uma anormalidade neurológica e, em alguns casos, podendo definir a etiologia do processo (D'ANGELO et al., 2009).

Em bovinos a evolução de determinadas encefalopatias possibilita a coleta do LCR em diferentes momentos, tornando possível monitorar o quadro clínico e/ou avaliar a eficácia do tratamento estabelecido, sendo que STOKOL et al. (2009) descreveram este tipo de conduta em animais internados em Hospital Veterinário. 
Apesar das pesquisas avaliarem a composição do LCR em bovinos clinicamente

2 saudáveis imediatamente após a coleta (WELLES et al., 1992) ou 24 horas após refrigeração

3 (D'ANGELO et al., 2009) e em animais com diferentes neuropatias (STOKOL et al., 2009),

4 não existe na literatura compilada estudos que detectaram se a primeira coleta do LCR altera

5 os resultados laboratoriais da segunda coleta.

6

7

O objetivo do presente trabalho foi verificar se uma primeira coleta de LCR em bovinos clinicamente sadios interfere nos resultados das análises citológicas e bioquímicas de uma segunda amostra obtida com intervalo de 96 horas.

\section{MATERIAL E METODOS}

(1)

Foram utilizados 12 bovinos da raça Nelore, machos com 8 a 10 meses de idade, sendo que todos os animais foram considerados hígidos após o exame físico. Os animais foram alimentados com feno Coast-cross (Cynodon dactylon) e água ad libitum durante todo o período experimental.

As duas coletas de LCR (M1 e M2) foram realizadas segundo protocolo proposto por MAYHEW (1989), com intervalo de 96 horas. Após sedação com cloridrato de xilazina ${ }^{\mathrm{a}}(0,20$ $\mathrm{mg} / \mathrm{kg} / \mathrm{IV}$ ), tricotomia e anti-sepsia com iodopovidona (PVPI) foi realizada punção na cisterna atlanto-occiptal com agulha spinal 20G x 3 1/2”b.

As amostras de LCR foram coletadas em três tubos de ensaio estéreis sem EDTA. Para análise do LCR foi utilizada uma fração da amostra do terceiro tubo. O número de leucócitos e hemácias por microlitro do LCR foi mensurado com o uso da câmara de Fuchs-Rosenthal. A contagem diferencial de leucócitos foi feita em lâminas preparadas por citocentrifugação ${ }^{c}$ e coradas com método Panótico ${ }^{\mathrm{d}}$. As proteínas ${ }^{\mathrm{e}}$ e a glicose ${ }^{\mathrm{f}}$ foram dosadas com kits comerciais, 
1 empregando o método colorimétrico, cujas leituras das reações foram feitas em espectrofotômetro ${ }^{\mathrm{g}}$.

A média e os desvios padrão foram calculados para todos os parâmetros laboratoriais do LCR avaliados e submetidos à análise estatística no programa GraphPad InStat versão 3.0 para Windows (GraphPad Software). O teste $\mathrm{T}$ pareado foi utilizado para as amostras que apresentaram distribuição normal (células nucleadas, linfócitos, macrófagos e proteínas) e o teste de Wilcoxon para os dados não paramétricos (células mononucleares, neutrófilos e glicose). Diferença estatística foi considerada para $\mathrm{p} \leq$ 0,05 (SAMPAIO, 1998).

\section{RESULTADOS E DISCUSSÃO}

A necessidade da sedação prévia dos animais antes da coleta do LCR no espaço atlanto-occiptal foi reportada por HOLBROOK \& WHITE (1992) e proporcionou uma contenção química eficaz para realização do procedimento de forma segura. A sedação dos animais para coleta do LCR não é recomendada por SCOTT (2004), mas quando os animais apresentam sinais neurológicos, pois esta conduta pode agravar o quadro clinico.

O intervalo de 96 horas entre as duas coletas foi estabelecido, pois este corresponde ao período normalmente utilizado pelos clínicos para realizar nova avaliação laboratorial do LCR, visando monitorar de forma mais eficiente a evolução do quadro clínico do paciente. Além disso, STOKOL et al. (2009) citaram que as principais causas de encefalite em bovinos são causadas por infecções bacterianas, portanto, este intervalo de 96 horas de coleta corresponde a aproximadamente metade do tempo de duração da antibioticoterapia, justificando a repetição da coleta do LCR com a finalidade de avaliação da eficácia da terapêutica e confirmação do prognóstico estabelecido. 

amostras, uma amostra com 680 hemácias/ $\mu \mathrm{L}$ e outra com 2590 hemácias/ $\mu \mathrm{L}$. Na segunda 3 coleta, identificou-se 0 até 100 hemácias/ $\mu \mathrm{L}$ em 8 amostras, de 100 até 500 hemácias/ $\mu \mathrm{L}$ em 3

4 amostras e 3.900 hemácias $/ \mu \mathrm{L}$ em uma amostra As mesmas não foram descartadas pois 5 HURT \& SMITH (1997), constataram que a presença de hemácias (dentro do intervalo de até 613200 por uL), causada pela contaminação iatrogênica em cães parece não interferir na contagem de leucócitos. Corroborando com este princípio, STOKOL et al. (2009) avaliaram o LCR de 102 casos de bovinos com doenças do SNC e só descartaram amostras que apresentaram contaminação com sangue acima de 50.000 hemácias $/ \mu \mathrm{L}$, justificando a 10 inclusão de todas as amostras do nosso estudo, visto que o maior valor foi de 3.900 11 hemácias $/ \mu \mathrm{L}$.

As contagens médias das células nucleadas dos animais (tabela 1) apresentaram diferença significativa entre os dois momentos. Na primeira coleta os valores médios permaneceram dentro do intervalo de normalidade (SCOTT, 1995), enquanto na segunda coleta os resultados médios indicaram pleocitose em nove animais, inclusive três amostras apresentaram resultados próximos de 40 células/ $\mu$ L. Para TVEDTEN (1987) a conclusão mais importante que pode ser obtida pela análise do LCR é a presença de inflamação, que é primariamente baseada no aumento do número de leucócitos (pleocitose).

Todas as amostras de LCR devem ser examinadas citologicamente, mesmo se a contagem total de células for normal (TVEDTEN, 1987). Na contagem diferencial das células nucleadas do LCR da primeira coleta foi observado que a mesma estava dentro dos padrões 22 normais com predomínio dos linfócitos, seguido por células mononucleares indiferenciadas, não sendo observada diferença significativa para estes tipos celulares entre os dois momentos avaliados (tabela 1). O LCR de bovinos sadios contém principalmente células mononucleares e corresponde a uma mistura de linfócitos e grandes células mononucleares (STOBER, 1993), 
1 inclusive as porcentagens de células mononucleares e linfócitos podem variar dependendo da

2 técnica utilizada para a preparação citológica (FREEMAN \& RASKIN, 2003).

$\mathrm{Na}$ contagem diferencial da segunda coleta observou-se predomínio de macrófagos com diferença significativa entre as duas coletas de LCR dos bovinos (tabela 1). O aumento da celularidade com predomínio dos macrófagos sugere ocorrência de inflamação devido à

6 primeira coleta, pois, minutos após a inflamação se iniciar, os macrófagos migram para o 7 local da lesão e começam sua ação fagocítica (JAIN, 1993).

Na contagem diferencial dos leucócitos não foi observada diferença significativa com relação aos neutrófilos entre os dois momentos de coleta (tabela 1). Baixas quantidades de neutrófilos no LCR na contagem diferencial eram sugestivas de alteração no SNC, mas, com

11 o aperfeiçoamento das técnicas laboratoriais especialmente na preparação de amostras 12 citológicas, pouca quantidade de neutrófilos tem sido relatada no LCR de animais sadios 13 (WELLES et al., 1992) justificando os achados da presente pesquisa.

Os teores médios de glicose no LCR dos bovinos não apresentaram diferença significativa entre os dois momentos de coleta (tabela 1) e os valores estavam dentro da faixa de normalidade, de 40mg/dL a $80 \mathrm{mg} / \mathrm{dL}$, para bovinos sadios (STOBER, 1993).

Os resultados da mensuração dos níveis de proteínas totais liquóricas apresentaram diferença significativa entre os dois momentos avaliados, sendo que os valores médios da primeira coleta permaneceram dentro dos parâmetros normais (valores inferiores a $40 \mathrm{mg} / \mathrm{dL}$ ) de acordo com SCOTT (1995), ao passo que na segunda coleta foi observado aumento 21 significativo para este parâmetro (tabela 1). Este achado indica a ocorrência de inflamação, 22 principalmente quando associada à pleocitose (FREEMAN \& RASKIN, 2003) como 23 observada na segunda coleta. 


\section{CONCLUSÃO}

4

De acordo com os resultados, pode-se concluir que as alterações observadas no LCR

6 na segunda coleta indicaram inflamação local detectável 96 horas após a primeira punção.

7 Esta informação é importante devido à necessidade de monitorar a evolução do quadro clínico e/ou avaliar a eficácia do tratamento estabelecido. Diante desta demanda, uma segunda coleta de LCR é frequentemente realizada, devendo-se considerar que possíveis alterações nos resultados da segunda coleta podem ser ocasionadas pela primeira punção, induzindo a uma

11 interpretação errônea da evolução do quadro clínico do paciente.

\section{AGRADECIMENTOS}

À CAPES pela bolsa PICDT de doutorado concedida ao primeiro autor. Ao CNPq pela bolsa de produtividade ao último autor e a FAPESP (2006/05836-6) pelo apoio financeiro.

\section{FONTES DE AQUISIÇÃO}

a - Vibaxil 2\% - Virbac Saúde Animal - Jurubatuba - SP - Brasil

b - Agulha spinal 20G x 3 1/2”-BD (CAT.408373) - São Paulo - SP - Brasil.

c - Citocentrífuga Citológica Microprocessada - 200D - CIENTEC- Piracicaba - SP -Brasil

d- Instant Prov -NEWPRO - Pinhais - PR - Brasil.

e - Sensiprot - Labtest Diagnóstica - Lagoa Santa - MG

f - Glicose Pap - Labtest Diagnóstica - Lagoa Santa - MG - Brasil. 
1 g - Espectrofotômetro Digital B 44242 -Micronal- São Paulo - SP - Brasil.

2

3 COMITÊ DE ÉTICA E BIOSSEGURANÇA

4

Todos os procedimentos realizados encontram-se de acordo com as normas e

6 princípios éticos de experimentação animal, estabelecidos pela Câmara de Ética em

7 Experimentação Animal da FMVZ/UNESP/Botucatu (Protocolo nº5/2007-CEEA).

\section{REFERÊNCIAS}

D'ANGELO et al. Analysis of cerebrospinal fluid from 20 calves after storage for 24 hours.

The Veterinary Record, v.18, n.164, p. 491- 493, 2009. Disponível em: < http://veterinaryrecord.bvapublications.com/cgi/reprint/164/16/491> Acesso em 26 ago. 2009. FREEMAN, K.P.; RASKIN, R.E. Citologia do sistema nervoso central. In: RASKIN, R.E.; MEYER, D.J. Atlas de citologia de cães e gatos. São Paulo: Roca, 2003. Cap 13, p.275-308. HOLBROOK, T.C.; WHITE, S.L. Ancillary test for assessment of the nervous system. In: WILSON, J.H. The veterinary clinics of North America food animal practice: Physical examination. W.B. SAUNDERS COMPANY, Philadelphia, Vol.8, n², 1992, 433p. HURT, A.E.; SMITH, M.O. Effects of iatrogenic blood contamination of results of cerebrospinal fluid analysis in clinically normal dogs and dogs with neurological disease.

21 Journal of the American Veterinary Medical Association, v. 211, p.866-867, 1997.

22 JAIN, N.C. Essentials of veterinary hematology. Philadelphia: Lea \& Febiger, 1993. 417p.

23 MAYHEW, I.G. Large animal neurology: a handbook for veterinary clinics. London: Lea 24 \& Febiger, 1989, 379p. 
1 SAMPAIO, I.B.M. Estatística Aplicada à Experimentação Animal. Belo Horizonte:

2 UFMG, 1998. 221p.

3 SCOTT, P.R. The collection and analysis of cerebrospinal fluid: an aid to diagnosis in

4 ruminant neurological diseases. British Veterinary Journal, v.151, p. 603-614, 1995.

5 SCOTT, P.R. Diagnostic techniques and clinicpathologic findings in ruminant neurological

6 disease. The Veterinary Clinics of North America: Food Animal Practice, 2004, v.20, $7 \quad 215-230 p$.

8 STÖBER, M. Sistema Nervoso Central. In: ROSEMBERG, G. Exame clínico dos bovinos.

9 Guanabara Koogan; Rio de Janeiro, 1993, 421p.

10 STOKOL et al. Cerebrospinal fluid findings in cattle with central nervous system disorders: a 11 retrospective study of 102 cases (1990-2008). Veterinary Clinical Pathology, v.38, n.1, 12 p.103-112, 2009. Disponível em: < http://www3.interscience.wiley.com/cgi$13 \mathrm{bin} /$ fulltext/121517631/PDFSTART> Acesso em 26 ago. 2009. DOI:10.1111/j.193914 165X.2008.00094.x

15 TVEDTEN, H. W. Clinical pathology of bovine neurologic disease. In: BAKER, J. D. Bovine 16 neurological diseases. The Veterinary Clinics of North America: Food Animal Practice, 17 1987, v.3, n.1, 24-44p WELLES, E. G. et al. Composition and analysis of cerebrospinal fluid in clinically normal 19 adult cattle. American Journal of Veterinary Research, v.53, n.11, p. 2050-2057, 1992. 
4 Tabela 1. Valores médios e desvios-padrão da contagem total e diferencial das células 5 nucleadas, dos teores de glicose $(\mathrm{mg} / \mathrm{dL})$ e proteína $(\mathrm{mg} / \mathrm{dL})$ das amostras do líquido 6 cefalorraquidiano colhidas em dois momentos (M1 e M2), com intervalo de 96 horas, de 7 bovinos Nelore saudáveis.

\begin{tabular}{c|c|c}
\hline \multirow{2}{*}{ Parâmetros } & \multicolumn{2}{|c}{ Momentos } \\
\cline { 2 - 3 } & $3,80 \pm 2,48 \mathrm{a}$ & $20,67 \pm 13,08 \mathrm{~b}$ \\
Células nucleadas (células/ $\boldsymbol{\mu L})$ & $6,78 \pm 13,10 \mathrm{a}$ & $2,75 \pm 8,90 \mathrm{a}$ \\
Células mononfilos (\%) & $30,88 \pm 30,87 \mathrm{a}$ & $21,83 \pm 21,41 \mathrm{a}$ \\
Linfócitos (\%) & $41,00 \pm 18,45 \mathrm{a}$ & $28,83 \pm 13,23 \mathrm{a}$ \\
Macrófagos (\%) & $21,33 \pm 16,96 \mathrm{a}$ & $45,00 \pm 22,30 \mathrm{~b}$ \\
Glicose (mg/dL) & $63,22 \pm 14,45 \mathrm{a}$ & $67,15 \pm 19,10 \mathrm{a}$ \\
Proteínas totais (mg/dL) & $21,09 \pm 2,44 \mathrm{a}$ & $45,38 \pm 3,88 \mathrm{~b}$ \\
\hline
\end{tabular}

8 Médias com letras minúsculas em uma mesma linha, seguidas de letras diferentes diferem 9 entre si $(\mathrm{p}<0,05)$. 

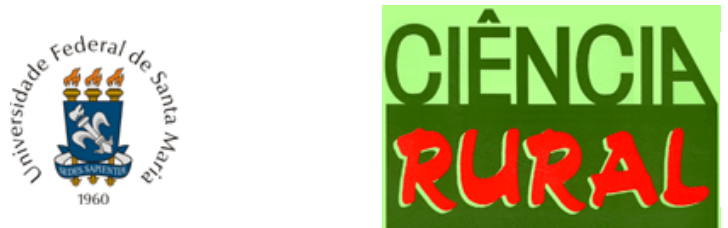

Português I English

Página inicial Artigos publicados Assinatura Indexação Consultores
Normas Situação do artigo Sobre nós Submissão online Taxas

Normas para publicação

1. CIÊNCIA RURAL - Revista Científica do Centro de Ciências Rurais da Universidade Federal de Santa Maria publica artigos científicos, revisões bibliográficas e notas referentes à área de Ciências Agrárias que deverão ser destinados com exclusividade.

2. Os artigos científicos, revisões e notas devem ser encaminhados via eletrônica editados em idioma Português ou Inglês, todas as linhas deverão ser numeradas e paginados no lado inferior direito. O trabalho deverá ser digitado em tamanho A4 210 x $297 \mathrm{~mm}$, com no máximo, 25 linhas em espaço duplo, as margens superior, inferior, esquerda e direita em 2,5cm, fonte Times New Roman, tamanho 12.0 máximo de páginas será 15 para artigos científicos, 20 para revisão bibliográfica e 8 para nota, incluindo tabelas, gráficos e ilustrações. Cada figura e ilustração deverá ser enviado em arquivos separados e constituirá uma página (cada tabela também constituirá uma página). Tabelas, gráficos e figuras não poderão estar com apresentação paisagem.

3. O artigo científico deverá conter os seguintes tópicos: Título (Português e Inglês); Resumo; Palavras-chave; Abstract; Key words; Introdução com Revisão de Literatura; Material e Métodos; Resultados e Discussão; Conclusão e Referências. Agradecimento(s) ou Agradecimento (s) e Apresentação; Fontes de Aquisição e Informe Verbal, quando for necessário o uso deve aparecer antes das referências. Antes das referências deverá também ser descrito quando apropriado que o trabalho foi aprovado pela Comissão de Ética e Biossegurança da instituição e que os estudos em animais foram realizados de acordo com normas éticas. (Modelo .doc, .pdf).

4. A revisão bibliográfica deverá conter os seguintes tópicos: Título (Português e Inglês); Resumo; Palavras-chave; Abstract; Key words; Introdução; Desenvolvimento; Conclusão; e Referências. Agradecimento(s) ou Agradecimento (s) e Apresentação; Fontes de Aquisição e Informe Verbal, devem aparecer antes das referências. Antes das referências deverá também ser descrito quando apropriado que o trabalho foi aprovado pela Comissão de Ética e Biossegurança da instituição e que os estudos em animais foram realizados de acordo com normas éticas. (Modelo .doc, .pdf).

5. A nota deverá conter os seguintes tópicos: Título (Português e Inglês); Resumo; Palavras-chave; Abstract; Key words; Texto (sem subdivisão, porém com introdução; metodologia; resultados e discussão e conclusão; podendo conter tabelas ou figuras); Referências. Agradecimento(s) ou Agradecimento (s) e Apresentação; Fontes de Aquisição e Informe Verbal, caso existam devem aparecer antes das referências. Antes das referências deverá também ser descrito quando apropriado que o trabalho foi aprovado pela Comissão de Ética e Biossegurança da instituição e que os estudos em animais foram realizados de acordo com normas éticas. (Modelo .doc, .pdf).

6. Não serão fornecidas separatas. Os artigos estão disponíveis no formato pdf no endereço eletrônico da revista www.scielo.br/cr.

7. Descrever o título em português e inglês (caso o artigo seja em português) - inglês português (caso o artigo seja em inglês). Somente a primeira letra do título do artigo deve ser maiúscula exceto no caso de nomes próprios. Evitar abreviaturas e nomes científicos no título. 0 nome científico só deve ser empregado quando estritamente necessário. Esses devem aparecer nas palavras-chave e resumo e demais seções quando necessários.

8. As citações dos autores, no texto, deverão ser feitas com letras maiúsculas seguidas do ano de publicação, conforme exemplos: Esses resultados estão de acordo com os reportados por MILLER \& KIPLINGER (1966) e LEE et al. (1996), como uma má formação congênita (MOULTON, 1978).

9. As Referências deverão ser efetuadas no estilo ABNT (NBR 6023/2000) conforme normas próprias da revista.

9.1. Citação de livro:

JENNINGS, P.B. The practice of large animal surgery. Philadelphia : Saunders, 1985. 2v.

TOKARNIA, C.H. et al. (Mais de dois autores) Plantas tóxicas da Amazônia a bovinos e outros herbívoros. Manaus : INPA, 1979. 95p.

9.2. Capítulo de livro com autoria:

GORBAMAN, A. A comparative pathology of thyroid. In: HAZARD, J.B.; SMITH, D.E. The thyroid. Baltimore : Williams \& Wilkins, 1964. Cap.2, p.32-48.

9.3. Capítulo de livro sem autoria:

COCHRAN, W.C. The estimation of sample size. In:

Sampling techniques. 3.ed. New York : John Willey, 1977. Cap.4, p.72-90.

TURNER, A.S.; McILWRAITH, C.W. Fluidoterapia. In: Técnicas cirúrgicas em animais de grande porte. São Paulo : Roca, 1985. p.29-40.

9.4. Artigo completo:

Sempre que possível o autor deverá acrescentar a url para o artigo referenciado e o número de identificação DOI (Digital Object Identifiers) conforme exemplos abaixo:

MEWIS, I.; ULRICHS, CH. Action of amorphous diatomaceous earth against different stages of the stored product pests Tribolium confusum (Coleoptera: Tenebrionidae), Tenebrio molitor (Coleoptera: Tenebrionidae), Sitophilus granarius (Coleoptera: Curculionidae) and Plodia interpunctella (Lepidoptera: Pyralidae). Journal of Stored Product Research, Amsterdam (Cidade opcional), v.37, p.153-164, 2001. Disponível em: <http://dx.doi.org/10.1016/S0022-474X(00)00016-3>. Acesso em: 20 nov. 2008. doi: 10.1016/S0022-474X(00)00016-3.

PINTO JUNIOR, A.R. et al (Mais de 2 autores). Resposta de Sitophilus oryzae (L.), Cryptolestes ferrugineus (Stephens) e Oryzaephilus 
surinamensis (L.) a diferentes concentrações de terra de diatomácea em trigo armazenado a granel. Ciência Rural , Santa Maria (Cidade opcional), v. 38, n. 8, nov. 2008 . Disponível em: <http://www.scielo.br/scielo.php?script=sci arttext\&pid=S010384782008000800002\&lng=pt\&nrm=iso>. Acesso em: 25 nov. 2008. doi: 10.1590/\$0103-84782008000800002.

9.5. Resumos:

RIZZARDI, M.A.; MILGIORANÇA, M.E. Avaliação de cultivares do ensaio nacional de girassol, Passo Fundo, RS, 1991/92. In: JORNADA DE PESQUISA DA UFSM, 1., 1992, Santa Maria, RS. Anais... Santa Maria : Pró-reitoria de Pós-graduação e Pesquisa, 1992. V.1. 420p. p.236.

9.6. Tese, dissertação:

COSTA, J.M.B. Estudo comparativo de algumas caracterísitcas digestivas entre bovinos (Charolês) e bubalinos (Jafarabad). 1986. 132f. Monografia/Dissertação/Tese (Especialização/ Mestrado/Doutorado em Zootecnia) - Curso de Pós-graduação em Zootecnia, Universidade Federal de Santa Maria.

9.7. Boletim:

ROGIK, F.A. Indústria da lactose. São Paulo : Departamento de Produção Animal, 1942. 20p. (Boletim Técnico, 20).

9.8. Informação verbal:

Identificada no próprio texto logo após a informação, através da expressão entre parênteses. Exemplo: ... são achados descritos por Vieira (1991 - Informe verbal). Ao final do texto, antes das Referências Bibliográficas, citar o endereço completo do autor (incluir E-mail), e/ou local, evento, data e tipo de apresentação na qual foi emitida a informação.

9.9. Documentos eletrônicos:

MATERA, J.M. Afeç̧ões cirúrgicas da coluna vertebral: análise sobre as possibilidades do tratamento cirúrgico. São Paulo : Departamento de Cirurgia, FMVZ-USP, 1997. 1 CD.

GRIFON, D.M. Artroscopic diagnosis of elbow displasia. In: WORLD SMALL ANIMAL VETERINARY CONGRESS, 31., 2006, Prague, Czech Republic. Proceedings... Prague: WSAVA, 2006. p.630-636. Acessado em 12 fev. 2007. Online. Disponível em: http://www.ivis.org/proceedings/wsava/2006/lecture22/Griffon1.pdf?LA=1

UFRGS. Transgênicos. Zero Hora Digital, Porto Alegre, 23 mar. 2000. Especiais. Acessado em 23 mar. 2000. Online. Disponível em: http://www.zh.com.br/especial/index.htm

ONGPHIPHADHANAKUL, B. Prevention of postmenopausal bone loss by low and conventional doses of calcitriol or conjugated equine estrogen. Maturitas, (Ireland), v.34, n.2, p.179-184, Feb 15, 2000. Obtido via base de dados MEDLINE. 1994-2000. Acessado em 23 mar. 2000. Online. Disponível em: http://www. Medscape.com/server-java/MedlineSearchForm

MARCHIONATTI, A.; PIPPI, N.L. Análise comparativa entre duas técnicas de recuperação de úlcera de córnea não infectada em nível de estroma médio. In: SEMINARIO LATINOAMERICANO DE CIRURGIA VETERINÁRIA, 3., 1997, Corrientes, Argentina. Anais... Corrientes : Facultad de Ciencias Veterinarias - UNNE, 1997. Disquete. 1 disquete de 31/2. Para uso em PC.

10. Desenhos, gráficos e fotografias serão denominados figuras e terão o número de ordem em algarismos arábicos. A revista não usa a denominação quadros. As figuras devem ser enviadas à parte, cada uma sendo considerada uma página. Os desenhos figuras e gráficos (com largura de no máximo $16 \mathrm{~cm}$ ) devem ser feitos em editor gráfico sempre em qualidade máxima com pelo menos 800 dpi em extensão .tiff. As tabelas devem conter a palavra tabela, seguida do número de ordem em algarismo arábico e não devem exceder uma lauda. Também devem apresentar a seguinte formatação que se encontra nesse exemplo.

11. Os conceitos e afirmações contidos nos artigos serão de inteira responsabilidade do(s) autor(es).

12. Será obrigatório o cadastro de todos autores nos metadados de submissão. O artigo não tramitará enquanto o referido item não for atendido. Excepcionalmente, mediante consulta prévia para a Comissão Editorial outro expediente poderão ser utilizados.

13. Lista de verificação (Checklist. doc,. pdf).

14. Os artigos serão publicados em ordem de aprovação.

15. Os artigos não aprovados serão arquivados havendo, no entanto, o encaminhamento de uma justificativa pelo indeferimento.

16. Em caso de dúvida, consultar artigos de fascículos já publicados antes de dirigir-se à Comissão Editorial. 